\title{
Experimental autoimmune myasthenia gravis : antibodies, idiotypes, and anti-idiotypes
}

Citation for published version (APA):

Verschuuren, J. J. G. M. (1989). Experimental autoimmune myasthenia gravis : antibodies, idiotypes, and anti-idiotypes. [Doctoral Thesis, Maastricht University]. Datawyse. https://doi.org/10.26481/dis.19890101jv

Document status and date:

Published: 01/01/1989

DOI:

10.26481/dis.19890101jv

Document Version:

Publisher's PDF, also known as Version of record

\section{Please check the document version of this publication:}

- A submitted manuscript is the version of the article upon submission and before peer-review. There can be important differences between the submitted version and the official published version of record.

People interested in the research are advised to contact the author for the final version of the publication, or visit the DOI to the publisher's website.

- The final author version and the galley proof are versions of the publication after peer review.

- The final published version features the final layout of the paper including the volume, issue and page numbers.

Link to publication

\footnotetext{
General rights rights.

- You may freely distribute the URL identifying the publication in the public portal. please follow below link for the End User Agreement:

www.umlib.nl/taverne-license

Take down policy

If you believe that this document breaches copyright please contact us at:

repository@maastrichtuniversity.nl

providing details and we will investigate your claim.
}

Copyright and moral rights for the publications made accessible in the public portal are retained by the authors and/or other copyright owners and it is a condition of accessing publications that users recognise and abide by the legal requirements associated with these

- Users may download and print one copy of any publication from the public portal for the purpose of private study or research.

- You may not further distribute the material or use it for any profit-making activity or commercial gain

If the publication is distributed under the terms of Article $25 \mathrm{fa}$ of the Dutch Copyright Act, indicated by the "Taverne" license above, 


\section{EXPERIMENTAL AUTOIMMUNE MYASTHENIA GRAVIS}

antibodies, idiotypes, and anti-idiotypes 


\section{EXPERIMENTAL AUTOIMMUNE MYASTHENIA GRAVIS}

\section{Proefschrift}

ter verkrijging van de graad van doctor

aan de Rijksuniversiteit Limburg te Maastricht, op gezag van de Rector Magnificus, Prof. Dr. F.I.M. Bonke, volgens het besluit van het College van Dekanen, in het openbaar te verdedigen op vrijdag, 17 november 1989 om 14.00 uur

door

Johannes Justus Gerard Maria Verschuuren geboren te Breda in 1961 
Promotor:

Co-promotor:

Beoordelingscommissie: Prof. Dr. P.J.M. van der Lugt, Maastricht (voorzitter)

Prof. Dr. R.E. Ballieux, Utrecht

Prof. Dr. F.T. Bosman, Maastricht

Prof. Dr. H.J.G.H. Oosterhuis, Groningen

Prof. Dr. F. Spaans, Maastricht

CIP DATA KONINKLIJKE BLBLIOTHEEK DEN HAAG

Verschuuren, Johannes Justus Gerard Maria

Experimental atutoimmume myasthenia gravis : antibodies, idiotypes and anti-idiotypes / Johannes Justus Gerard

Maria Verschuuren. - Maastricht : Datawyse. - IIl.

Thesis Maastricht. - With ref. - With summary in Dutch.

ISBN 90-5291-009-x

SisO 605.18 UDC 616.74:612.017 (043.3)

Subject heading: myasthenia gravis / idiotype /

electromyography.

Produktie en lityout: Datawyse Maastricht

Druk: Krips Repro Meppel

Omslag ontwerp: Ineke Eyck

Het in dit proefschrift gepresenteerde onderzoek werd in belangrijke mate mogelijk gemaakt door subsidies van de Nederlandse organisatie voor Wetenschappelijk Onderzoek (NWO) en het Beatrix Fonds

In de drukkosten van het proefschrift werd bijgedragen door de firma Merck Sharp \& Dohme en Becton Dickinson. 
Was jedermann für ausgemacht hält, verdient am meisten untersucht zu werden

G.C. Lichtenberg, 1742-1799

Opgedragen aan mijn ouders

Voor Ank 


\section{CONTENTS}

INTRODUCTION

\section{CHAPTER 1}

Acetylcholine receptors, myasthenia gravis and experimental autoimmune myasthenia gravis

Introduction

Acetylcholine receptor

Myasthenia gravis

Experimental autoimmune myasthenia gravis

References

\section{CHAPTER 2}

Role of acetylcholine receptor antibody complexes in muscle in experimental autoimmune myasthenia gravis

Introduction

Material and Methods

Results

Discussion

References

\section{CHAPTER 3}

Single fiber electromyography in experimental autoimmune myasthenia gravis

Introduction

Material and Methods

Results

Discussion

References

\section{CHAPTER 4}

Idiotypes in myasthenia gravis

Idiotypes and anti-idiotypes

Idiotypes in myasthenia gravis 


\section{CHAPTER 5}

Paratope and framework related crossreactive idiotopes on anti-acetylcholine receptor antibodies

Introduction

Material and Methods

Results

Discussion

References

CHAPTER 6

In vivo effects of neonatal administration of antiidiotype antibodies on experimental autoimmune myasthenia gravis in the rat

Introduction

Material and Methods

Results

Discussion

References

SAMENVATTING

PUBLICATIONS 


\section{INTRODUCTION}

Myasthenia gravis is a disease affecting the neuromuscular junction. Autoantibodies binding the nicotinic acetylcholine receptor are found in the sera of 70-90\% of the patients $(2,4)$. These antibodies are responsible for the clinical symptoms, as is demonstrated by passive transfer of antibodies from mother to child during pregnancy, from patient to experimental animal, and by the benificial effects of plasmapheresis; all showing the importance of the presence or removal of these autoantibodies against the acetylcholine receptor $(1,7,8)$. Several mechanisms are thought to be responsible for the impairment of the neuromuscular function which can be found in myasthenia gravis, all resulting in a loss of acetylcholine receptor from the postsynaptic membrane or disturbed function of the remaining receptors (3). Myasthenia gravis is a relatively uncommon disorder, with an incidence of about 4 per million (5), nevertheless it is intensively studied. This can be explained through the availability of an excellent animal model, initially characterized by Patrick and Lindstrom (6), but also by the fact that knowledge obtained regarding the pathogenesis and therapeutic manipulations might also be useful in other autoimmune (receptor) diseases, for which a well characterized animal model is not available. In fact, myasthenia gravis is the only autoimmune receptor disease for which the antigen is known in detail, and a feasible, well characterized animal model has been developed. This model is based on the induction of myasthenia gravis by immunization with acetylcholine receptor. It has succesfully been applied in several species of animals, including rat, mice, goats and monkeys $(3,6)$.

The aim of this study was twofold. First, the animal model of experimental autoimmune myasthenia gravis was optimized, in order to be able to analyze in detail the effects of immunomodulatory strategies. Secondly, the idiotype-anti-idiotype network in experimental autoimmune myasthenia gravis was analyzed in vitro, and in viwo by means of passive transfer of anti-idiotypic antisera.

Thus, this thesis consists of two parts. In part one the model of EAMG is further elaborated. It starts with an introduction on myasthenia gravis and the experimental animal model. As pointed out in this chapter, myasthenia gravis is characterized by autoantibodies to the nicotinic acetylcholine receptor, and loss of acetylcholine receptor from muscle. In chapter 2 the role of anti-acetylcholine receptor antibodies bound to the acetylcholine receptor in muscle, in terms of mediating the disease, is analyzed. An improved assay for determination of acetylcholine receptor-antibody complexes in muscle is presented, and their role in relation to symptoms of disease is analyzed. In the third chapter the application of stimulated single fiber elec- 
tromyography in the rat is deseribed. As yet, this sensitive diagnostic test had not been used for diagnostic procedures in experimental autoimmune myasthenia gravis in the rat.

Part two starts with an introduction on the concept of idiotypes and the idiotype network theory. This theory was introduced by Jerne in 1974 and has greatly influenced the ideas on immunoregulation, since the anti-idiotype regulation of the humoral immune response has been shown to be possible in several hapten related idiotype systems. We therefore studied the possibilities of anti-idiotype regulation of the immune response in experimental autoimmune myasthenia gravis. In chapter 5 the idiotypes associated with monoclonal anti-AChR antibodies are described. Crossreactive idiotopes in the rat as well in mice are identified, and an assay for determination of idiotype positive antibodies in serum is described. In the sixth chapter the in vivo effects of passive transferred anti-idiotypes in neonatal rats are examined in order to determine whether or not anti-idiotypic antibodies are able of suppressing or enhancing the immune response against the acetylcholine receptor, and whether or not the idiotype expression in the serum is affected. 


\section{References}

1. Donaldson JO, Penn AS, Lisak RP, Abramsky O, Brenner T, Schotland DL (1981) Antiacetylcholine receptor antibody in neonatal myasthenia gravis. Am J Dis Child 135:222-226

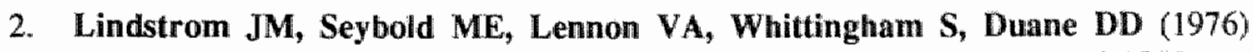
Antibody to acetylcholine receptor in myasthenia gravis. Neurology 26:1054-1059

3. Lindstrom J, Shelton D, Fujii Y (1988) Myasthenia gravis. Adv Immunol 42:233-284

4. Mossman S, Vincent A, Newsom-Davis J (1986) Myasthenia gravis without acetylcholine receptor antibody: a distinct disease entity. Lancet $\mathrm{i}: 116-118$

5. Oosterhuis HJGH (1981) Observations of the natural history of myasthenia gravis and the effect of thymectomy. Ann N Y Acad Sci 337:678-689

6. Patrick J, Lindstrom JM (1973) Autoimmune response to acetylcholinereceptor. Science 180:871-872

7. Pinching AJ, Peters DK, Newsom-Davis J (1976) Remission of myasthenia gravis following plasma exchange. Lancet II: 1373-1376

8. Toyka KV, Drachman DB, Griffin DE, Pestronk A, Winkelstein JA, Fischbeck KH, Kao I (1977) Myasthenia gravis. Study of humoral immune mechanisms by passive transfer to mice. N Engl J Med 296:125-131 


\section{ACETYLCHOLINE RECEPTORS, MYASTHENIA GRAVIS AND EXPERIMENTAL AUTOIMMUNE MYASTHENIA GRAVIS}

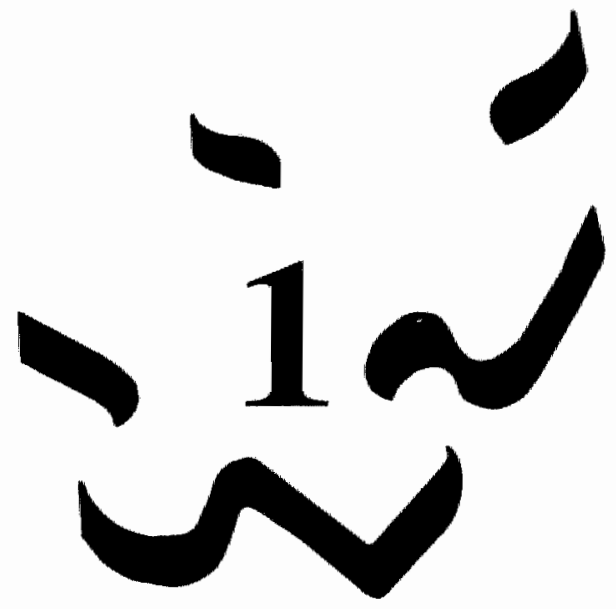




\section{Introduction}

Myasthenia gravis (MG) has been a puzzling disease of unclear origin for over a century. Various hypotheses have been put forward in order to explain the phenomena associated with this disease, and many different therapies have been tried (105) or are proposed (138). It was noticed that the abnormal fatiguebility in MG resembled curare poisoning. Therefore, Walker treated a MG patient with physostigmin, known to be a partial antagonist of curare, and a remarkable improvement of the clinical condition of the patient was seen (153); this observation was soon confirmed (115). In 1960 Simpson proposed that auto-antibodies "with the properties of an acetylcholine-competitive-blocking substance" might be involved (131), and Nastuk observed that the sera of some patients were cytotoxic for muscle cells (94). In 1971 ultrastructural studies by Engel and Santa clearly showed a postsynaptic defect (30), and two years later in 1973 experiments performed in rabbits by Patrick and Lindstrom suggested an autoimmune response against the acetylcholine receptor (AChR) as a cause of MG (109). In the same year Fambrough, Drachman and Satyamurti demonstrated a loss of $\mathrm{AChR}$ at the neuromuscular junctions of MG patients (35). Progress in MG research was made using new techniques, including purification of AChR by means of a neurotoxin, radioimmunoassays of circulating antibodies, mapping of pathogenic epitopes by monoclonal antibodies, and by recombinant DNA technology $(2,75,109)$. Nowadays $M G$ is known as an autoimmune disease, caused by an antibody mediated response to the nicotinic AChR in skelletal muscle (84).

In order to understand the pathophysiology of $\mathrm{MG}$, it is necessary to study the structure and function of the AChR at the neuromuscular endplate, since AChRs are the target of the autoimmune attack in MG.

\section{Acetylcholine receptor}

\section{Structure and distribution}

AChR is a transmembrame glycoprotein residing in the postsynaptic membrame of vertebrate neuromuscular junction and is present in high concentration in electric organs of some fish (114), like the Torpedo californica, a marine elasmobranch (a kind of electric fish), living in the South Pacific Ocean, or the electric eel, living in the Amazone river. The electric organs of these fishes form a rich source of AChR 
(up to $100 \mathrm{mg} / \mathrm{kg}$ ) (114). Therefore, much information about this protein derives from studies performed on this fish $A C h R$, most of which can also be applied to the mammalian skeletal muscle $A C h R$, because the $A C h R$ is an evolutionary well conserved molecule (114).

In normal skeletal muscle the postsynaptic membrame is folded and has about 10 times the length of the presynaptic nerve membrame $(125,126)$. The synaptic space between the nerve ending and the top of the folds is $50-80 \mathrm{~nm}$. The AChR molecule is about $110 \AA$ long, with $55 \AA$ extending above, and $15 \AA$ extending below the membrame (114). In both fish and mammalians the AChRs are composed of four subunits arranged in a $250,000-298,000 \mathrm{MW}$ complex $(24,85,120)$ with the subunit stochiometry $\alpha-\beta-\alpha-\gamma-\delta(64,80,116,120)$. In innervated skeletal muscle AChRs are located at the postsynaptical membrane of the neuromuscular synaps. In non-innervated (foetal) or denervated muscle the AChR is present all over the sarcolemmal surface (150) and, although grossly similar in pharmacological, biochemical and physical properties, it differs in several aspects with the junctional $A C h R$, including differences in structure (91), gating properties (150), density on the membrane (150), and interaction with anti-AChR antibodies (156). At mature neuromuscular junctions the AChRs probably contain subunits, whereas before innervation (foetal) or after denervation of muscle this subunit is replaced by $\gamma$ subunits (91). Experiments in the rat soleus muscle suggest that the embryonic form of the AChR plays an important role in allowing spontaneous contractile activity in developing muscles (54). Genetic engineering methods made it possible to isolate the cDNA clones of all subunits from AChR of Torpedo californica $(99,101,102)$, mammalian $\mathrm{AChR}(65,100,134,135)$, and recently human $\mathrm{AChR}(7)$. The overall homology is $\approx 80 \%$ between the $\alpha$ subunit from Torpedo AChR and calf muscle (100) and about $55 \%$ between the other subunits $(65,134,135)$, indicating that they probably derived from one ancestral gene (116). The technique for the production of monoclonal antibodies (60), and later on for the production of synthetic peptides corresponding to the primary sequence of the AChR has led to a detailed analysis of the structure of the AChR and its functional sites $(139,140,142)$, and enabled the analysis of the $B$ cell antigenic determinants (epitopes) $(17,87,95,117)$ and $T$ cell epitopes on the $\operatorname{AChR}(39,51,52)$.

\section{Antigenic structure of the $\mathrm{AChR}$}

The symptoms in MG are antibody mediated and can be transferred by purified IgG (136). On the other hand the production of anti-AChR antibodies is T cel dependent $(14,20,37,63,70,89)$. Thus, both $B$ and $T$ cell epitopes on the AChR are important. 
To analyse $B$ cell epitopes on the $A C h R$ mAbs have been prepared against the AChR $(16,46,53,82,139,143,145,156)$, recognizing a minimum of 30 extracellular, intracellular, as well as intramembraneous epitopes. Many mAbs reacted with more than one subunit, but the subunit used for immunizatiuon was always recognized best (45). After immunization with solubilized AChR animals produce antibodies against many parts of the $\mathrm{AChR}$, but over $50 \%$ is directed at the extracellular part (36), more precisely the main immunogenic region (MIR) $(139,140,142)$. This epitope has been mapped on the $\alpha$ subunit at amino acid residues 67 to $76(5,6$, I18,147). Anti-MIR mAbs are now defined as antibodies which compete with $\mathrm{mAb}$ 35 (reference anti-MIR mAb) for binding to the intact AChR (6il). In MG patients $39-50 \%$ of the antibodies in their sera was reported to be directed at the MIR $(52,141)$. Antigenic determinants associated with the MIR are conformation dependent, as they are destroyed by denaturation of the AChR $(36,118,119)$. It was shown that mAbs directed at the MIR do not bind to Torpedo AChR, after destruction of conformational dependent determinants by reduction and carboxymethylation (21).

Another B cell epitope on the AChR which has been repeatedly investigated is the acetylcholine binding site. Antibodies to the acetylcholine binding site have usually been demonstrated in MG patients by showing the inhibition of binding of $\alpha$ bungarotoxin to $\mathrm{AChR}(2)$. A variable fraction $0-33 \%$ (155) or $1-54 \%$ (148) of the antibodies in MG is directed at the acetylcholine binding site. This epitope has been mapped on the $\alpha$ subunit at residue 160-214 (6), and more precisely using synthetic peptides to residues 173-204 (157) and 185-196 (96).

AChR immune $T$ cells respond well to native AChR and SDS denaturated subunits $(20,39,62)$, and frequently react with more than one subunit. To identify in more detail the $T$ cell epitopes synthetic peptides have been used. In several studies synthetic peptides (for example, peptides coding for part of the $\alpha$-subunit: $\alpha 169$ $181, \alpha 351-368, \alpha 251-271$ ) have been found to stimulate lymphocyte cultures from MG patients $(39,52)$. In contrast to the $B$ cell response, for which the MIR appears to form the immunodominant epitope, no immunodominant sequence for $T$ cell recognition has been found yet (84), although preferential recognition of the $\alpha$-subunit has been described (50,51). In comparing B and T cell recognition of the AChR, it was observed that $\mathrm{T}$ cells do not recognize synthetic subunit peptides, which bind to antibodies against native AChR or denaturated subunits $(39,117)$. This is probably due to the fact that $T$ cells only are activated by denaturated, proteolytic fragments of antigens presented by antigen-presenting cells in the context of MHCproducts. In experimental animals $\mathrm{T}$ cell recognition was $\mathrm{MHC}$ restricted, e.g. synthetic peptides found to stimulate in vitro proliferation of AChR-immune $T$ cells from Lewis rats were found to be different from those sets of synthetic peptides stimulating T cells from Brown-Norway, Wistar-Furth or Buffalo rats (39). 
In conclusion, $B$ cells predominantly recognize an immunodominant, conformation dependent, epitope on the $\alpha$ subunit, the MIR, and crossreactivity of antibodies among subunits is low. T cells recognize non-conformational dependent epitopes on all the AChR subunits which may be different from those appreciated by B cells without a single dominant one, and show high cross-reactivity among AChR subunits.

\section{Function and pharmacology}

Each $\alpha$-subunit contains an acetylcholine (ACh) binding site; cooperative binding of two ACh molecules triggers the AChR and leads to opening of a cation channel, which is an integral part of the AChR. Opening is effectuated in less than $100 \mu \mathrm{s}$, and persists for $\approx 1 \mathrm{~ms}$, followed by a non-conductance state of $\approx 50 \mathrm{~ms}$ during which time period the $A C h R$ is non-sensitive to a second hit of acetylcholine $(1,22$, $27,111)$.

\section{Myasthenia gravis}

\section{Definition}

Myasthenia gravis is an autoimmune disease affecting the neuromuscular junction. An antibody mediated attack of the postsynaptic membrane results in excessive fatigue and weakness of voluntary muscles, which is generalized or restricted to ocular muscles. Symptoms can be relieved by administration of an acetylcholine esterase inhibitor.

Serum antibodies against the AChR can be found in about $85-90 \%$ of patients with generalised MG and about $70 \%$ of those with symptoms restricted to ocular muscles $(75,93)$.

Electromyographicallly the disease is characterized by a decrementing response to repetitive stimulation, and increased jitter if single fiber electromyography is used to study the neuromuscular transmission (124). 


\section{Myasthenia gravis in man}

MG typically presents as an adult acquired disease. Although MG is a relatively uncommon disorder, with an incidence of about 4 per million (104), several congenital, adult or infantile, and immune or non-immune MG-like syndromes have been described $(34,103,132,151)$.

Within the disease entity of autoimmune MG several subforms have been distinghuised, and patients can be divided according to several criteria, including muscle groups involved, age of onset, and presence of thymoma (107). Based on these criteria MG patients have been divided in three main groups $(15,152)$ :

1) patients with thymoma, peak age of onset between 30 and 50 years, without clear HLA association, and no predominance of sex.

2) patients with thymic hyperplasia and age of onset less than 40 years, who were frequently HLA A1,B8 and/or DR3 positive, and tend to be female.

3) patients with age of onset above 40 years, who had thymic atrophy and were frequently HLA A3,B7 and/or DR2 positive, and tend to be male.

It was suggested that the different thymic pathology and age of onset in these groups might be related to different etiological events or predisposing conditions (152). However, although MG can be regarded as the best characterized autoimmune disease of the nervous system, it is still unknown what initiates and sustains the immune response to AChR. Most likely a combination of multiple factors contributes trough a final common pathway to the induction of the disease (84). A viral infection leading to thymic changes and initiating loss of self tolerance for the AChR has been proposed (86); no virus was detected or isolated from the thymusses from 19 MG patients (152), but another study demonstrated an association of Epstein-bar virus with 3 of 3 thymomas and with 2 of 4 cases of thymic hyperplasia (88). Bacterial antigens have also been implicated in the pathogenesis of this autoimmune process $(28,133)$. Age, sex, and HLA markers have been associated with increased risk for the development of MG $(15,58)$. Iatrogenic factors, like drugs (42) and bone marrow grafting $(13,67,68,149)$ might contribute to the initiation of the disease. The thymus is thought to play a central role in the pathogenesis of MG. The majority of the patients have thymic abnormalities including thymoma, thymic hyperplasia, and germinal centers (154). The hyperplastic thymusses contain anti-AChR antibody producing $B$ cells and $T$ helper cells might be sensitized by AChR expressing myoid cells $(55,89,154)$. Thymomas are seen in approximately $15 \%$ of the MG patients, $30-40 \%$ of the thymomas is associated with MG (105). Thymectomy is generally considered to be potentially effective, especially for MG patients younger than 45 years old and within 3-5 years of onset of the disease (106). Thymic abnormalities also form the main point of difference between MG and experimental autoimmune models of MG (EAMG) induced by immunization with AChR. EAMG is very similar to MG regarding clinical, electrophysiological, 
histological, biochemical and immunological parameters, but no thymic abnormalities are found (78). Neveretheless, EAMG has proven to be a valuable model for studying MG (84).

\section{Experimental autoimmune myasthenia gravis}

\section{Introduction}

In 1973 Patrick and Lindstrom purified the AChR on snake venom columns. To characterize the protein, which they had isolated from the electric organs of eels, they immunized rabbits. Suprisingly the rabbits developed a flaccid form of paralysis and decrementing electromyograms, which could both be relieved by acetylcholinesterase ińhibitors. Most rabbits weakened and died (109). Immunization of severall species of animals, including rats, mice, goats, guinea pigs and monkeys, induced EAMG $(8,14,69,77,78)$. So, in spite of the phylogenetically large differences, electric organ AChR must have retained sufficient antigen homology to $A C h R$ of mammalian skeletal muscle to induce antibodies against self- $A C h R$.

\section{Chronic versus acute EAMG}

EAMG in animals can be induced by immunization with AChR in complete Freund adjuvant (CFA), or by repeated administration of low dose monoclonal antibody. These strategies all cause chronic forms of EAMG. On the other hand acute EAMG can be seen after passive transfer of polyclonal or monoclonal antibodies, and after immunization with AChR in CFA with additional immunization with Bordetella pertussis organisms. These different forms of EAMG will be discussed below in more detail.

In rats EAMG can be induced by immunization with purified eel or Torpedo AChR (77), fetal calf muscle AChR (29), and syngeneic rat AChR (77) incorporated in CFA. Immunization with $1 \mu \mathrm{g}$ or more of Torpedo AChR in CFA results in antibodies to Torpedo $\mathrm{AChR}$ and crossreactive anti-rat $\mathrm{AChR}$ antibodies. Maximum titers are usually achieved 30-40 days after immunization, when also the first clinical signs of myasthenia are seen $(12,79)$. These symptoms are generalized weakness, resulting in low head with chin and elbows on the floor, hunched back, abducted tighs and flexed digits. In severe EAMG excessive growth of teeth and weightloss are apparent. Loud respiratory noises may be present indicating chronic 
respiratory disease (72). AChR content of muscle can be measured, and a maximum AChR loss of two-thirds has been found in rats with EAMG (81). Induction of EAMG in mice by immunization with $A C h R$ in membranes, derived from mouse tumor cell line $\mathrm{BC} 3 \mathrm{H}-1$, without adjuvant is possible, although less effective (127). Chronic EAMG can also be induced by repeated administration of one monoclonal anti-AChR antibody for 9-12 weeks (44). This leads to a reduction of the AChR content of the muscles and a decreased miniature endplate potential (MEPP), but no clinical weakness or decremental response to repetitive stimulation was observed (44).

Immunization with synthetic peptides corresponding to defined sequences of the AChR is able to induce chronic EAMG. A peptide corresponding to residues 125-147 of the $\alpha$-subunit, which is shared by Torpedo and human AChR and exposed at the extracellular side, induced antibodies capable of modulation of native AChR in human muscle cells in vitro. It also induced clinical signs of EAMG in one rat, and electrophysiological and/or biochemical manifestations of EAMG in 10 of 11 rats $(72,87)$. Other groups did not find signs of EAMG in rats or rabbits immunized with oligopeptides containing overlapping sequences $(18,95)$. Only antibodies reacting with peptides corresponding to amino acid sequences of the extracellular surface of the AChR cause disease (117). Epitopes on the extracellular part of the AChR, recognized by antibodies, are often conformation dependent. Synthetic peptides, although containing the right residues, are mostly devoid of this particular three dimensional structure and therefore induce antibodies which do not recognize native $\mathrm{AChR}$.

Acute EAMG can be induced by passive transfer of polyclonal or monoclonal anti-AChR antibodies $(43,78,146)$. Signs of EAMG, similar to those found in chronic EAMG, are induced within 12-48 hr after administration with a maximum at 48-60 hr, depending on the dose. As little as 107 pmol polyclonal anti-rat $\mathrm{AChR}$ antibody (79) or $150 \mathrm{pmol}$ mAb 6 (139) is sufficient to induce symptoms of acute EAMG. At $72 \mathrm{hr}$ after administration rats either die or recover and no active immune response to AChR persists. Acute EAMG induced by injection of antiAChR mAbs is similar to the acute form, which occurs 8-10 days after immunization of rats with $\mathrm{AChR}$ in CFA with additional immunization with Bordetella pertussis $(77,78)$. Additional immunization with Bordetella pertussis organisms is essential for the development of the acute phase of disease (84).

It has been demonstrated that inbred strains of rats differ in their susceptibility to EAMG. Two strains, Wistar Furth and Copenhagen, were reported to be resistant; up to 6 months after immunization with $100 \mu \mathrm{g}$ Torpedo AChR in CFA and three further injections of $50 \mu \mathrm{g}$ at two weeks interval, they remained clinically indistinguishable from controls. Lewis rats exhibited intermediate susceptibility, and 
Fischer and Wistar Munich rats showed most severe disease, with none of the rats recovering. Crossbreeding experiments with resistant Wistar Furth and susceptible Wistar Munich, indicated linkage to only one or two genetic loci. Crossbreeding in mice showed that the disease phenotype may be linked to several undefined loci in addition to $\mathrm{H} 2$ (mouse HLA) and immunoglobulin alleles $(8,9,37)$. In both rats and mice the haplotype, especially the $\mathrm{H} 2$ or major histocompatibility complex (MHC) locus, apparently is not the only factor determining the severity of EAMG, and other not yet identified genetic factors determine the susceptibility to EAMG.

\section{Pathomorphology of the neuromuscular junction}

Before the AChR was identified as the most important antigen to which the antibody response is directed, several studies had described a variety of abnormalities of MG end plates $(158,159)$. Engel and Santa performed a histometric analysis of the ultrastructure of the neuromuscular junction (30). Alterations of the postsynaptic membrane implicated a postsynaptic defect in MG. After development of the EAMG model in the rat, similar morphological abnormalities of the neuromuscular junction have been described in detail in this animal model (31).

After immunization of Lewis rats with Torpedo AChR in CFA along with Bordetella pertussis, two phases of EAMG can be distinguished, as described above. In the acute phase light microscopic analysis shows an inflammatory exsudate composed of mainly mononuclear cells, confined to regions of the motor endplates. Electron microscopic examinations revealed degenerating tips of the postsynaptic folds immediately below the degenerating junctional folds, postsynaptic folds splitting away of the underlying fiber region and segmental necrosis. Macrophages invading this region were observed, probably sequestering remnants of the postsynaptic folds, and thereby separating intact nerve terminals from the muscle fibers. Because of severe destruction, morphometric methods could not be used for evaluation of the postsynaptic membrane.

In chronic EAMG, three weeks or more after immunization, light microscopic studies show rare or no macrophages near the neuromuscular junction, and no necrosis. By means of electron microscopy a highly simplified postsynaptic membrane is seen, whereby the primary synaptic space is widened and contains remnants of degenerating folds, and amorphous material or debris. Macrophages are not observed. Morphometric evaluation revealed a significant reduction of the length of the postsynaptic membrane (31). 
The changes of the neuromuscular junction observed in MG patients closelly resemble those seen in the chronic phase of EAMG in the rat $(30,31)$. For the acute phase of EAMG $(69,71)$ no human equivalent is known, although in some MG biopsies mononuclear cell infiltrates are found; but there is no clear evidence that they are related to the end plate pathology (150).

\section{Attack of the neuromuscular junction by the immune apparatus}

The lymphocytes in the immune system can be grossly divided in two large families: $B$ and $T$ cells. The $B$ cell population, including plasmacells, are responsible for the production of antibodies, participating in the humoral immune response. $T$ cells, involved in the cellular immune response, can be divided in regulating $T$-helper cells ( $\mathrm{T}_{\mathrm{h}}$-cells), and $\mathrm{T}$-suppressor/cytotoxic cells $\left(\mathrm{T}_{\mathrm{S}} / \mathrm{T}_{\mathrm{c}}-\mathrm{cells}\right)$.

\section{Role of humoral immune response}

The symptoms of $\mathrm{MG}$ are caused by circulating autoantibodies to the $\mathrm{AChR}$. Several studies support this view. Anti-AChR antibodies have been detected in $67-93 \%$ of MG patients $(66,74,75,110)$. Passive transfer of IgG from these patients to mice induces acute EAMG, decrement and AChR loss in these animals $(136,137)$. Plasmapheresis appears effective in the treatment of MG patients $(19,97,113)$. In babies born to mothers, suffering from $\mathrm{MG}$, transient myasthenic symptoms, neonatal myasthenia gravis, and the presence of anti- $\mathrm{AChR}$ antibodies have been described (23). Cellular immune reactions play a less important role in the immune attack of the neuromuscular junction. Cellular infiltrates are rarely seen in the muscles of MG patients $(30,31)$, and lymphocytes isolated from animals with EAMG were not cytolytic for muscle cells (38).

There are several mechanisms proposed to explain the electrophysiological and morphological abnormalities in MGr. A large amount of this knowledge is derived from the EAMG model in the rat.

\section{Antigenic modulation}

The normal mechanism of turnover of AChR involves endocytosis followed by proteolytic degradation within the lysosomes (41). Turnover of junctional AChR in organ cultures of rat diaphragm muscle is characterized by a half life of $190 \mathrm{hr}$ (47). Crosslinking of the AChR on muscle cells by antibodies increases degradation 2-6 fold $(3,4,47,56)$. This phenomenon has been termed antigenic modulation of the AChR. This process is independent of complement, but can be inhibited by disturb- 
ing the energy metabolism, the cytoskeletal function or by low temperature (3). A clonal muscle cell line, $\mathrm{BC} 3 \mathrm{H}-1$, which can be cultured in vitro was used to study antigenic modulation by EAMG sera (81). Addition of purified rat anti-AChR IgG increased the rate of $\mathrm{AChR}$ destruction, while monovalent Fab fragments were ineffective (81). Junctional AChR on diaphragms removed from EAMG rats are destroyed at twice the normal rate (90). These results suggest that antigenic modulation of the AChR does occur in vivo in EAMG.

A similar mechanism may be involved in the autoimmune pathogenesis of MG. MG immunoglobulin or its divalent fragment, $\mathrm{F}(\mathrm{ab})_{2}$, was demonstrated to accelerate degradation of AChR in rat skeletal muscle cells in vitro $(25,56)$. Monovalent Fab from myasthenic serum had no effect on degradation, but addition of a second antibody, capable of crosslinking the Fab fragments, resulted in a threefold increase of degradation (25). Similar results were shown in other studies $(3,47)$, and the results were confirmed using human myotubes to show that myasthenic sera decrease surface AChR on these cells by at least one-half of those of controls. In addition, it was found that when AChR loss was compared to the concentration of anti-AChR antibodies added, the sera of severely ill MG patients were equally effective as the sera from patients with a mild form of the disease (144). This finding suggests that there are no exceptionally effective antibodies in severely ill patients as far as their modulating capacity in cell cultures is concerned.

\section{Complement binding at the postsynaptic membrane}

Clustering of $\operatorname{lgG}$ after binding to surface antigens is able to activate the classical complement pathway, resulting in the production of $\mathrm{C} 3 \mathrm{a}$ and $\mathrm{C} 5 \mathrm{a}$, which both are anaphylotoxins, resulting in mast cell activation and an inflammatory reaction, which is able to attrack phagocytic cells. C3b and C3bi, bound to the cell surface, further facilitate the binding of these latter cells. By activating all components up to C9 a membrane attack complex, penetrating the cell membrane, is formed.

In acute EAMG these complement molecules may be important for the attraction and binding of macrophages to the motor endplate region. Indeed, passive transfer of $\mathrm{MG}$ by antibodies from MG patients to $\mathrm{C} 3$ depleted mice or $\mathrm{C} 5$ deficient guinea pigs is impaired by the absence of an intact complement system (71).

In chronic EAMG and MG the complement system is thought to be involved in focal lysis of the muscle membrane $(31,121)$. This can be concluded from the demonstration of $\mathrm{C} 9$ on the postsynaptic membrane in myasthenic muscle (122). As very rare infiltrates are seen in chronic. EAMG or MG, although bound $\mathrm{C} 3$ is present at the endplates $(32,121)$, the rate of complement inactivation probably exceeds the rate of 
activation (8). This might be due to the reduced amount of AChR at the postsynaptic membrane, and therefore a decreased density of bound $\operatorname{IgG}$, which in turn can only activate small amounts of complement factors in contrast to acute EAMG (84).

\section{Direct block of AChR function}

Independent of antigenic modulation or complement, antibodies are able to directly affect the function of the $\mathrm{AChR}$, either by binding to the acetylcholine binding site or by allosteric inhibition of the channel function $(11,14,57,76,109)$. Reduction of MEPP amplitude has been seen in muscles of human (123), rat (130), or mouse (129) origin under conditions were accelerated degradation should be minimal. Myasthenic antibodies have been shown to block binding of $\alpha$-bungarotoxin to cultured chick $(40)$ and rat $(26,92)$ and human muscle $(2,148,155)$ cells.

\section{Role of the cellular immune response}

Little morphological evidence suggests a direct cellular attack on the end plate in MG or chronic EAMG $(32,84,121)$, although an early 'acute' phase of disease could go undetected in MG. However, MG rarely presents as an acute illness, and the acute EAMG observed in rats can be attributed to the use of additional adjuvant $(69,71,84)$. Thus, the mononuclear cell infiltrate observed at the neuromuscular junction is probably confined to the model of acute EAMG (31).

It is clear that B cells and their products dominate the effector phase of the pathophysiology of MG and EAMG. There is evidence, however, that the production of anti- $A C h R$ antibodies is $T$ cell dependent. Lennon demonstrated positive skin tests, typical of delayed type hypersensitivity, in rats immunized with eel $A C h R$, and transfer of EAMG with lymphnode cells (70). The induction of EAMG and the development of anti-AChR antibodies could be prevented in rats which were depleted of $T$ cells by thymectomy and $X$-irradiation and were constituted only with $B$ cells before challenge with AChR with adjuvant. This demonstrates the helper function of $\mathrm{T}$ cells for the antibody production by $\mathrm{B}$ cells.

Not only in vivo, but also in vitro $T$ cell dependence of the antibody response was shown, since removal of $\mathrm{T}$ cells from lymphenode cell preparations of EAMG rats resulted in a dramatic reduction of both AChR-induced proliferation and antibody production in vitro (20).

There is a genetic predisposition associated with class II HLA antigens (14,15), and T cells sensitized to AChR were demonstrated and isolated in EAMG and MG $(48,49,51,108,128)$. 
These results demonstrate the general importance of regulatory $T$ cells in the pathogenesis of MG and EAMG. It has been suggested that the determinants recognized by $T$ cells will influence and direct the $B$ cell response towards the AChR (51). Therefore, specificity and function of T cells in MG and EAMG has to be studied to elucidate how $\mathrm{T}$ and $\mathrm{B}$ cells cooperate in eliciting an (auto)immune response against a complex protein like the $\mathrm{AChR}$. 


\section{References}

1. Adams PR (1981) Acetylcholine receptor kinetics: J Membr Biol 58:161-174

2. Almon RR, Andrew CG, Appel SH (1974) Serum globulin in myasthenia gravis: inhibition of $\alpha$-bungarotoxin binding to acetylcholine receptors. Science 186:55-57

3. Appel SH, Anwyl R, McAdams MW, Elias S (1977) Accelerated degradation of acetylcholine receptor from cultured rat myotubes with myasthenia gravis sera and globulins. Proc Natl Acad Sci 74:2130-2134

4. Ashizawa T, Elias SB, Appel SH (1982) Interaction of myasthenic immunoglobulins and cholinergic agonists on acetylcholine receptors of rat myotubes. Ann Neurol 11:2227

5. Barkas T, Gabriel JM, Mauron A, Hughes GJ, Roth B, Alliod C, Tzartos SJ, Ballivet M (1980) Monoclonal antibodies to the main immunogenic region of the acetylcholine receptor bind to residues $61-76$ of the $\alpha$ subunit. J Biol Chem 263:5916-5920

6. Barkas T, Mauron A, Roth B, Alliod C, Tzartos SJ, Ballivet M (1987) Mapping the main immunogenic region and toxinbinding site of the nicotinic acetylcholine receptor. Science 235:77-80

7. Beeson D, Brydson M, Vuncent A, Newsom-Davis J (1989) Isolation and expression of cDNAs for the human muscle nicotinic acetylcholine receptor. Proceedings of ' 2 nd European conference on myasthenia gravis' p. 21 (abstract)

8. Berman PW, Patrick J (1980) Linkage between the frequency of muscular weakness and loci that regulate immune responsiveness in murine experimental myasthenia gravis. J Exp Med 152:507-520

9. Berman PW, Patrick J (1980) Experimental myasthenia gravis. J Exp Med 151:204-223

10. Berman PW, Heinemann SF (1984) Antigenic modulation of junctional acetylcholine receptor is not sufficient to account for the development of myasthenia gravis in receptor immunized mice. J Immunol 132:711-717

11. Bevan S, Kullberg RW, Heinemann SF (1977) Human myasthenic sera reduce acetylcholine sensitivity of human muscle cells in tissue culture. Nature 267:263 265

12. Biesecker G, Koffler D (1988) Resistance to experimental autoimmune myasthenia gravis in genetically inbred rats. J Immunol 140:3406 3410

13. Bolger GB, Sullivan KM, Spence AM, Appelbaum FR, Johnston R, Sanders JE, Deeg HJ, Witherspoon RP, Doney KC, Nims J, Thomas ED, Storl R (1986) Myasthenia gravis after allogeneic bone marrow transplantation: relationship to chronic graft-versus-host disease. Neurol 36:1087-1091

14. Christadoss P, Lennon VA, David C (1979) Genetic control of experimental autoimmune myasthenia gravis in mice. I. Lymphocyte proliferative pesponse to acetylcholine receptor is under $\mathrm{H}-2$ linked Ir gene control. I Immunol 123:2540-2543 
15. Compston DAS, Vincent A, Newsom-Davis J, Batchelor JR (1980) Clinical, pathological, HLA antigen and immunological evidence for disease heterogeneity in myasthenia gravis. Brain 103:579-601

16. Conti-Tronconi B, Trartos $\mathrm{S}$, Lindstrom $\mathrm{J}$ (1981) Monoclonal antibodies as probes of acetylcholine receptor structure. I. binding to native receptor. Biochem 20:2181-2191

17. Criado M, Hochschwender $\mathbf{S}$, Sarin V, Fox JL, Lindstrom J (1985) Evidence for unpredicted transmembrane domains in acetylcholine receptor units. Proc Natl Acad Sci 82:2004-2008

18. Criado M, Sarin V, Fox JL, Lindstrom J (1986) Evidence that the acetylcholine binding site is not formed by the sequence $\alpha 127-143$ of the acetylcholine receptor. Biochem $25: 2839-2846$

19. Dau PC, Lindstrom JM, Cassel CK, Denys EH, Shev EE, Spitler LE (1977) Plasmapheresis and immunosuppressive drug therapy in myasthenia gravis. $N$ Engl J Med 297:1134-1140

20. De Baets MH, Einarson B, Lindstrom JM, Weigle WO (1982) Lymphocyte activation in experimental autoimmune myasthenia gravis. J Immunol 128:2228-2235

21. De Baets MH (1984) Autoimmunity to cell surface receptors. Thesis, BV Leiter-Nypels, Maastricht pp. 94-95

22. Dionne VE, Leibowitz (1982) Acetylcholine receptor kinetics. A description from single-channel currents at snake neuromuscular junctions. Biophys J 39:253-261

23. Donaldson JO, Penn AS, Lissak RP, Abramsky O, Brenner T, Schotland DL (1981) Anti-acetylcholine receptor antibody in neonatal myasthenia gravis. Am J Dis Child $135: 222-226$

24. Doster W, Hess B, Watters D, Maelicke A (1980) Translational diffusion coefficient and molecular weight of the acetylcholine receptor from Torpedo marmorata. FEBS lett $113: 312-314$

25. Drachman DB, Angus CW, Adams RN, Michelson JD, Hoffman GJ (1978) Myasthenic antibodies cross-link acetylcholine receptors to accelerate degradation. $\mathrm{N}$ Engl J Med 298:1116-1122

26. Drachman DB, Adams N, Josifek LF, Pestronk A, Stanley EF (1981) Anti-body mediated mechanisms of $\mathrm{ACh}$ receptor loss in myasthenia gravis: clinical relevance. Ann N Y Acad Sci 377: 175-87

27. Dreyer F (1982) Acetylcholine receptor. Br J Anaesth 54:115-130

28. Dwyer DS, Vakil M, Bradley RJ, Oh SJ, Kearney IF (1987) A possible cause of myasthenia gravis: idiotypic networks involving bacterial antigens. Ann N Y Acad Sci $505: 461 \cdot 471$

29. Einarson B, Gullick W, Conti-Tronconi B, Ellisman M, Lindstrom J (1982) Subunit composition of bovine muscle acetylcholine receptor. Biochem 21:5295-5302

30. Engel AG, Santa T (1971) Histometric analysis of the ultrastructure of the neuromuscular junction in myasthenia gravis and in the myasthenic syndrome. Ann N Y Acad Sci $183 ; 46-63$ 
31. Engel AG, Tsujihata M, Lindstrom JM, Lennon VA (1976) The notor end plate in myasthenia gravis and in experimental autoimmune myasthenia gravis. A quantative ultrastructural study. Ann N Y Acad Sci 274:60-79

32. Engel AG, Lambert EH, Howard FM (1977) Immune complexes (IgG and C3) at the motor end-plate in myasthenia gravis. Ultrastructural and light microscopic localization and electrophysiologic correlations. Mayo Clin Proc 52:267-280

33. Engel WK, Trotter JL, McFarlin DE, McIntosh CL (1977) Thymic epithelial cell contains acetylcholine receptor. Lancet II:1310-1311

34. Engel AG, Lambert EH, Mulder DM, Gomez MR, Whitaker JN, Hart Z, Sahashi K (1981) Recently recognized congenital myasthenic syndromes: (A) End-plate acetylcholine (ACh) esterase deficiency (B) Putative abnormality of the $\mathrm{ACh}$ induced ion channel (C) Putative defect of ACh resynthesis or mobilization. Clinical features, ultrastructure and cytochemistry. Ann N Y Acad Sci 377:614-639

35. Fambrough DM, Drachman DB, Satyamurti $\mathbf{S}$ (1973) Neuromuscular junction in myasthenia gravis: decreased acetylcholine receptors. Science 182:293-295

36. Froehner SC (1981) Identification of exposed and buried determinants of the membranebound acetylcholine receptor from Torpedo californica. Biochem 20:4905-4915

37. Fuchs S, Nevo D, Tarrab-Hazdai R (1976) Strain differences in the autoimmune response of mice to acetylcholine receptors. Nature $263: 329-330$

38. Fuchs $\mathbf{S}$ (1979) Immunology of the nicotinic acetylcholine receptor. Curr Top Microbiol Immunol 85:1-29

39. Fujii Y, Lindstrom J (1988) Specificity of the $\mathrm{T}$ cell immune response to acetylcholine receptor in experimental aytoimmune myasthenia gravis. J Immunol 140:1830-1837

40. Fulpius BW, Lefvert AK, Cuênoud S, Mourey A (1981) Properties and serum levels of specific populations of anti-acetylcholine receptor antibodies in myasthenia gravis. Ann N Y Acad Sci 377:307-315

42. Garlepp MJ, Dawkins RL, Christiansen FT (1983) HLA antigens and acetylcholine receptor antibodies in penicillamine induced myasthenia gravis. Brith Med J 286:338-340

43. Gomez CM, Richman DP (1985) Monoclonal anti-acetylcholine receptor antibodies. with differing capacities to induce experimental autoimmune myasthenia gravis. I Immunol 135:234-241

44. Gomez CM, Richman DP (1987) Chronic experimental autoimmune myasthenia gravis induced by monoclonal antibody to acetylcholine receptor: biochemical and electrophysiologicall criteria. J Inmunol 139:73-76

45. Gullick WJ, Lindstrom JM (1982) The antigenic structure of the acetylcholine receptor from Torpedo californica. J Cell Biochem 19:223-230

46. Gullick WJ, Lindstrom JM (1983) Mapping the binding of monoclonal antibodies to the acety $\|$ choline receptor from Torpedo californica. Biochen 22:3312-3320

47. Heinemann S, Merlie J, Lindstrom J (1978) Modulation of acetylcholine receptor in rat diaphragm by anti-receptor sera. Nature 274:65-68 
48. Hohlfeld $\mathrm{R}$, Kalles I, Heinz $\mathbf{F}$, Kalden JR, Wekerle H (1981) Autoimmune rat T lymphocytes monospecific for acetylcholine receptors: purification and fine specificity. J Imnumol 126:1355-1359

49. Hohlfeld $\mathbf{R}$, Toyka KV, Heininger $\mathbf{K}$, Grosse-Wilde $\mathbf{H}$, Kalles I (1984) Autoimmune human T lymphocytes specific for acetylcholine receptor. Nature 310:244-246

50. Hohlfeld R, Toyka $\mathbf{K V}$, Michels $\mathbf{M}$, Heininger $\mathbf{K}$, Conti-Tronconi $\mathbf{B}$, Tzartos SJ (1987) Acerylcholine receptor-specific human T-lymphocyte lines. Ann N Y Acad Sci 505:27-38

51. Hohlfeld R, Toyka KV, Tzartos SJ, Carson W, Conti-Tronconi BM (1987) Human T-helper lymphocytes in myasthenia gravis recognize the nicotinic receptor $\alpha$ subunit. Proc Natl Acad Sci $84: 5379$

52. Hohlfeld R, Toyka KV, Miner LL, Walgrave SL, Conti-Tronconi BM (1988) Amphipathic segment of the nicotinic receptor $\alpha$ subunit contains epitopes recognized by T lymphocytes in myasthenia gravis. J Clin Invest $81: 657-660$

53. Holton B, Tzartos SJ, Changeux J-P (1984) Comparison of embryonic and adult Torpedo acetylcholine receptor by sedimentation characteristics and antigenicity. Int J Devl Neuroscience 2:549-555

54. Jaramillo F, Vicini S, Schuetze SM (1988) Embryonic acetylcholine receptors guarantee spontaneous contractions in rat de veloping muscle. Nature 325:66-68

55. Kao I, Drachman DB (1977) Thymic muscle cells bear acetylcholine receptors: possible relation to myasthenia gravis. Science 195:74-75

56. Kao I, Drachman DB (1977) Myasthenic immunoglobulin accelerates acetylcholine receptor degradation. Science 196:527-529

57. Karlin A, Holtrman E, Valderrama R, Damle V, Hsu K, Reyes F (1978) Binding of antibodies to acetylcholine receptors in Electrophorus and Torpedo electrolplax membranes. J Cell Biol 76:57

58. Kerzin-Storrar L, Metcalfe RA, Dyer PA, Kowalska G, Ferguson I, Harris R (1988) Genetic factors in myasthenia gravis: A family study. Neurol 38:38-42

59. Klavinskis LS, Willcox HNA, Richmond JE, Newsom-Davis J (1986) Attempted isolation of viruses from myasthenia gravis thymus. J Neuroimmunol 11:287-299

60. Köhler G, Milstein C (1975) Continuous cultures of fused cells secreting antibody of predefined specificity. Nature 256:495-497

61. Kordossi AA, Trartos SJ (1989) Monoclonal antibodies against the main immunogenic region of the acetylcholine receptor. Mapping on the intact molecule. J Neuroimmunol $23: 35-40$

62. Krollick KA, Urso O (1986) Influence of $\mathrm{T}$ cell specificity on the antibody response to acetylcholine receptor. J Neuroimmunol 13:75-87

63. Krolick KA, Urso OE (1987) Analysis of helper-T-cell functionj by acetylcholine receptor-reactive cell lines of defined AChR-subunit specificity. Cell Immunol 105:7585 
64. Kubalek E, Ralston S, Lindstrom J, Unwin N (1987) Localization of subunits within the acetylcholine receptor by electron image analysis of tubular crystals from Torpedo marmorata. J Cell Biol 105:9-18

65. Kubo T, Noda M, Takai T, Tanabe T, Kayano T, Shimizu S, Tanaka K, Takahashi H, Hirose T, Inayama S, Kikuno R, Miyata T, Numa S (1984) Primary stucture of $\delta$ subunit precursor of calf muscle acetylcholine receptor deduced from cDNA sequence. Eur J Biochem 149:5-13

66. Lefvert AK, Bergstrom K, Matell G, Osterman PO, Pirskanen R (1978) Determination of acetylcholine receptor antibody in myasthenia gravis: clinical usefulness and pathogenetic implications. J Neurol Neurosurg Psych 41:394-403

67. Lefvert AK, Bolme P, Hammerström L, Lönnqvist B, Ringden O, Slordahl S, Smith CIE (1987) Bona marrow grafting selectively induces the production of acetylcholine receptor antibodies, immunoglobulins bearing related idiotypes, and antiidiotypic antibodies. Ann N Y Acad Sci 377:825-827

68. Lefvert AK, Björkholm M (1987) Antibodies against the acetylcholine receptor in hematologic disorders: implications for the development of myasthenia gravis after bone marrow grafting. N Engl J Med 317:170

69. Lennon VA, Lindstrom JM, Seybold ME (1975) Experimental autoimmune myasthenia: a model of myasthenia gravis in rats and guinea pigs. J Exp Med 141:1365-1375

70. Lennon VA, Lindstrom JM, Seybold ME (1976) Experimental autoimmune myasthenia gravis: cellular and humoral immune responses. Ann N Y Acad Sci 274:283-299

71. Lennon VA, Seybold ME, Lindstrom JM, Cochrane C, Ulevitch R (1978) Role of complement in the pathogenesis of experimental autoimmune myasthenia gravis. J Exp Med 147:973-983

72. Lennon VA, McCormick DJ, Lambert EH, Griesmann GE, Atassi MZ (1985) Region of peptide 125-147 of acetylcholine receptor $\alpha$ subunit is exposed at neuromuscular junction and induces experimental autoimmune myasthenia gravis, T-cell immunity, and modulating autoantibodies. Proc Natl Acad Sci. 82:8805-8809

73. Lerrick AJ, Wray D, Vincent A, Newsom-Davis J (1983) Electrophysiological effects of myasthenic serum factors studied in mouse muscle. Ann Neurol 13:186-191

74. Limburg PC, The T, Hummel-Tappel E, Oosterhuis HJGH (1983) Anti-acetylcholine receptor antibodies in myasthenia gravis. Part 1. Relation to clinical parameters in 250 patients. J Neurol Sci 58:357-370

75. Lindstrom JM, Seybold ME, Lennon VA, Whittingham S, Duane DD (1976) Antibody to acetyicholine receptor in myasthenia gravis. Neurology 26:1054-1059

76. Lindstrom JM, Lennon VA, Seybold ME, Whittingham S (1976) Experimental autoimmune myasthenia gravis and myasthenia gravis: Biochemical and immunochemical aspects. Ann N Y Acad Sci 274:254-274 
77. Lindstrom JM, Einarson BL, Lennon VA, Seybold ME (1976) Pathological mechanisms in experimental autoimmune myasthenia gravis. 1. Immunogenicity of syngeneic muscle acetylcholine receptor and quantative extraction of receptor and antibody-receptor complexes from muscles of rats with experimental autoimmune myasthenia gravis. J Exp Med 144:726-738

78. Lindstron JM, Engel AG, Seybold ME, Lennon VA, Lambert EH (1976) Pathological mechanisms in experimental autoimmune myasthenia gravis. II. Passive transfer of experimental autoimmune myasthenia gravis in rats with anti-acetylcholine receptor antibodies. J Exp Med 144:739-753

79. Lindstrom $J$ (1979) Alutoimmune response to acetylcholine receptors in myasthenia grawis and its animal model. Adv Immunol 27:1-50

80. Lindstrom J, Merlie J, Yogeeswa ran G (1979) Biochemical properties of acetylcholine receptor subunits from Torpedo californica. Biochem 18:4465-4470

81. Lindstrom J, Einarson B (1979) Antigenic modulation and receptor loss in experimental autoimmune myasthenia gravis. Muscle Nerve 2:173-179

82. Lindstrom J, Criado $\mathbf{M}$, Hochschwender S, Lawrence Fox J, Sarin V (1984) Immunochernical tests of acetylcholine receptor subunit models. Nature 322:573-575

83. Lindstrom J (1985) Immunobiology of myasthenia gravis, experimental autoimmune myasthenia gravis, and Lambert-Eaton syndrome. Ann Rev Immunol 3:109-131

84. Lindstrom J, Shelton D, Fujii Y (1988) Myasthenia gravis. Adv Immunol 42:233-284

85. Lo MMS, Barnard EA, Dolly JO (1982) Size of acetylcholine receptors in the membrane. An improved version of the radiation inactivation method. Biochem 21 : 2210-2217

86. Lubetzki I, Abramsky O (1981) Myasthenia following wiral infection. Eur Neurol 20:435-439

87. MeCormick DJ, Griesmann GE, Huang Z-X, Lambert EH, Lennon VA (1987) Myathenogenicity of human acetylcholine receptor syntheric $\alpha$-subunit peptide 125 -147 does not require intramolecular disulfide cyclization. J Immunol 139:2615-2619

88. MeGuire LJ, Huang DP, Teoh R, Arnoll M, Wong K, Lee JCK (1988) Epstein-Bar virus genome in thymoma and thymic lymphoid hyperplasia. Am J Pathol 131:385-390

89. Melms A, Schalke BCG, Kirchner Th, Müller-Hermelink HK, Albert E, Wekerle H (1988) Thymus in myasthenia gravis. Isolation of T-lymphocyte lines specific fot the nicotinic acetylcholine receptor from thymuses of myasthenic patients. $J$ Clin Invest $81: 902-908$

90. Merlie JP, Heinemann S, Lindstrom JM (1979) Acetylcholine receptor degradation in adult rat diaphragms in organ culture and the effect of anti-acetylcholine receptor antibodies. J Biol Chem 254:6320-6327

91. Mishina M, Takai T, Imoto K, Noda M, Takahashi T, Numa S (1986) Molecular distinction between fetal and adult forms of muscle acetylcholine receptor. Nature $321: 406-411$ 
92. Mittag TW, Xu X, Moshoyiannis H, Kornfeld P, Genkins G (1984) Analysis of false negative results in the immunoassay for anti-acetylcholine receptor antibodies in myasthenia gravis. Clin Immunol Immpath 31:191-201

93. Mossman S, Vincent A, Newsom-Davis J (1986) Myasthenia gravis without acetylcholine receptor antibody: a distinct disease entity. Lancet $\mathrm{i}: 116-118$

94. Nastuk WL, Plescia OJ, Osserman KE (1960) Changes in serum complement activity in patients with myasthenia gravis. PSEBM v105:177-184

95. Neumann D, Gershoni JM, Fridkin M, Fuchs S (1985) Antibodies to synthetic peptides as probes for the binding site on the $\alpha$-subunit of the acetylcholine receptor. Proc natl Acad Sci 82:3490-3493

96. Neumann D, Barchan D, Fridkin M, Fuchs S (1986) Analysis of ligand binding to the synthetic dodecapeptide 185-196 of the acetylcholine receptor $\alpha$ subunit. Proc Natl Acad. Sci 83:9250-9253

97. Newsom-Davis J, Pinching AJ, Vincent A, Wilson SG (1978) Function of circulating antibody to acetylcholine-receptor in myrasthenia gravis investigated by plasma exchange. Neurol 28:266-272

98. Newsom-Davis J, Wilson SG, Vincent A, Ward CD (1979) Long-term effects of repeated plasma exchange in myasthenia gravis. Lancet I:464-468

99. Noda M, Takahashi H, Tanabe T, Toyosato M, Furutani $Y$, Hirose T, Asai M, Inayama S, Miyata T, Numa S (1982) Primary structure of $\alpha$-subunit precursor of Torpedo californica acetylcholine receptor deduced from cDNA sequence. Nature 299:793-797

100. Noda M, Furutani Y, Takahashi H, Toyosato M, Tanabe T, Shimizu S, Kikyotani S, Kayano T, Hirose T, Inayama S, Numa S (1983) Cloning and sequence analysis of calf cDNA encoding $\alpha$-subunit precursor of muscle acetylcholine receptor. Nature 305:818-823

101. Noda M, Takahashi H, Tanabe T, Toyosato M, Kikyotani S, Hirose T, Asaï M, Takashima H, Inayama S, Miyata T, Numa S (1983) Primary structures of $\boldsymbol{B}$ - and $\delta$-subunit precursors of Torpedo californica acetylcholine receptor deduced from cDNA sequences. Nature 301:251-255

102. Noda M, Takahashi H, Tanabe T, Toyosato M, Kikyotani S, Furutani $\mathbf{Y}$, Hirose $T$, Takashima H, Inayama S, Miyata T, Numa S (1983) Structural homology of Torpedo californica acetylcholine receptor subunits. Nature $302: 528-532$

103. O'Neill JH, Murray NMF, Newsom-Davis J (1988) The Lambert-Eaton myasthenic syndrome. A review of 50 cases. Brain 111:577-596

104. Oosterhuis HJGH (1981) Observations of the naturall history of myasthenia gravis and the effect of thymectomy. Ann N Y Acad Sci 337:678-689

105. Oosterhuis HJGH (1984) Myasthenia gravis, In: Clinical Neurology and Neurosurgery monographs vol. 5, GH Glaser Ed, Churchill Livingstone, Edinburgh 
106. Oosterhuis HJCH, Limburg PC, Hurnmel-Tappel E, van den Burg W, The TH (1985) Anti-acetylcholine receptor antibodies in myasthenia gravis. Part 3. The effect of thymectomy. J Neurol Sci $69: 335-343$

107. Oosterhuis HJGII (1988) Long-term effects of treatment in 374 patients with myasthenia gravis. Monogr Allergy 25.75-85

108. Pachner AR, Cantor FS (1985) Helper $T$ cell lines specific for the acetylcholine receptor: induction, characterization, and in vivo effects. Clin immunol Immunopathol 35:245-251

109. Patrick J, Lindstrom JM (1973) Autoimmune response to acetylcholinereceptor. Sicience 180:871-872

110. Penn AS, Schotland DL, Lamme S (1986) Antimuscle and antiacetylcholine receptor antibodies in myasthenia gravis. Muscle Nerve 9:407-415

111. Peper K, Bradley RJ, Dreyer F (1982) The acetylcholine receptor at the neuromuscular junction. Physiol Rev 62:1271-1340

112. Pflugfelder CM, Cardinet GH, Lutz H, Holliday TA, Hansen RJ (1981) Acquired canine myasthenia gravis: immunocytochemical localization of immune complexes at neuromuscular junctions. Muscle Nerwe 4:289-295

113. Pinching AJ, Peters DK, Newsom-Davis J (1976) Remission of myasthenia gravis following plasma exchange. Lancet II: 1373-1376

114. Popot J-L, Changeux J-P (1984) Nicotinic receptor of acetylcholine: structure of an oligomeric integral membrane protein. Physiol Rev 64:1162-1239

115. Pritchard EAB (1935) The use of"prostigmen"in the treatment of myasthenia gravis. Lancet 1:432-434

116. Raftery MA, Hunskapiller MW, Stradler CD, Hood LE (1980) Acetylcholine receptor: complex of homologous subunits. Science 208:1454-1457

117. Ralston S, Sarin V, Thanh HL, Rivier J, Fox JL, Lindstrom J (1987) Synthetic peptides used to locate the $\alpha$-bungarotoxin binding site and immunogenic regions on $\alpha$ subunits of the nicotinic acetylcholine receptor. Biochem 26:3261-3266

118. Ratman M, Sargent PB, Sarin V, Fox JL, Nguyen DL, Rivier J, Criado M, Lindstrom J (1986) Localization of antigenic determinants on primary sequences of subunits of nicotinic acetylcholine receptor by peptide mapping. Biochem 25:2621-2632

1 19. Ratnam M, Nguyen DL, Rivier J, Sargent PB, Lindstrom J (1986) Transmembrane topography of nicotinic acetylcholine receptor: immunochemical tests contradict theoretical predictions based on hydrophobicity profiles. Biochem 25:2633-2643

120. Reynolds JA, Karlín A (1978) Molecular weight in detergent solution of acetylcholine receptor from Torpedo californica. Biochem 17:2035-2038

121. Sahashi K, Engel AG, Lindstrom JM, Lambert EH, Lennon VA (1978) Ultrastructural localization of immune complexes (IgG and C3) at the end-plate in experimental autoimmune myasthenia gravis. J Neurol Exp Neur 37:212-223 
122. Sahashi K, Engel AG, Lambert EH, Howard FM (1980) Ultrastructural localization of the terminal and lytic ninth complement component (C9) at the motor endplate in myasthenia gravis. J Neuropathol Exp Neurol 39:160-172

123. Sanders DB, Kim YI, Howard JF, Johns TR, Muller WH (1981) Intercostal muscle biopsy studies in myasthenia gravis: clinical correlations and the direct effects of drugs and myasthenic serum. Ann N Y Acad Sci 377:544

124. Sanders DB (1987) The electrodiagnosis of myasthenia gravis. Ann N Y Acad Sci $505: 539-556$

125. Santa T, Engel AG, Lambert EH (1972) Histometric study of neiromuscular junction ultrastructure. I. Myasthenia gravis. Neurology 22:71-82

126. Santa T, Engel AG, Lambert EG (1972) Histometric study of neuromuscular junction ultrastructure. II. Myasthenic syndrome. Neurology 22:370-376

127. Scadding GK, Calder L, Vincent A, Prior C, Wray D (1986) Anti-acetylcholine receptor antibodies induced in mice by syngeneic receptor without adjuvants. Immunology 58:151-155

128. Schalke BCG, Klinkert WEF, Wekerle H, Dwyer DS (1985) Enhanced activation of a T cell line specific for acetylcholine receptor (AChR) by using anti-AChR monoclonal antibodies plus receptor. J Immunol 134:3643-3648

129. Schuetze SM, Vicini S, Hall ZW (1985) Myasthenic serum selectively blocks acetylcholine receptors with long channel open times at developing rat endplates. Proc Natl Acad Sci 82:2533-2537

130. Shibuya $\mathbf{N}(1978)$ Serum factor blocks neuromuscular transmission in myasthenia gravis: electrophysiologic study with intracellular microelectrodes. Neurol 28:804-811

131. Simpson JA (1960) Myasthenia gravis: a new hypothesis. Scottish Med J 5:419-436

132. Smit LME, Hageman G, Veldman H, Molenaar PC, Oen BS, Jennekens FGI (1988) A myasthenic syndrome with congenital paucity of secondlary synaptic clefts: CPSC syndrome. Muscle Nerve 11:337-348

133. Stefansson K, Dieperink ME, Richman DP, Marton LS (1987) Sharing of epitopes by bacteria and the nicotinic acetylcholine receptor: a possible role in the pathogenesis of myasthenia grawis. Ann N Y Acad Sci 505:451-460

134. Takai T, Noda M, Furutani Y, Takahshi H, Notake M, Shimizu S, Kayano T, Tanabe T, Tanaka K, Hirose $T$, Inayama $S$, Numa $S$ (1984) primary structure of $\gamma$ subunit precursor of calf-muscle acetylcholine receptor deduced from the cDNA sequence. Eur J Biochem 143:109 115

135. Tanabe T, Noda M, Furutani Y, Takai T, Takahshi H, Tanaka K, Hürose T, Inayama $S$, Numa $S$ (1984) Primary structure of $\beta$ subunit precursor of calf muscle acetylcholine receptor deduced from cDNA sequence. Eur J Biochem 144:11-17

136. Toyka KV, Drachman DB, Griffin DE, Pestronk A, Winkelstein JA, Fischbeck KH, Kao I (1977) Myasthenia gravis. Study of humoral immune mechanisms by passive transfer to mice. N Engl J Med 296:125-131 


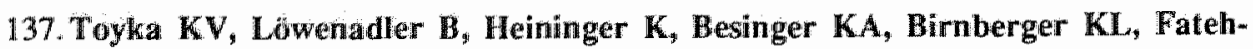
Moghadam A, Heilbronn E (1980) Passively transferred myasthenia gravis: protection of mouse end-plates by Fab fragments from human myasthenia IgG. J Neurol Neurosurg Psych 43:836-842

138. Toyka KV, Hohlfeld R, Heininger K (1988) Myasthenia gravis: New therapeutic strategies. Monogr Allergy 25:108-115

139. Tzartos SJ, Lindstrom JM (1980) Monoclonal antibodies used to probe acetylcholine receptor structure: Localization of the main immunogenic region and detection of similarities between subunits. Proc natl Acad Sci 77:755-759

140. Tzartos SJ, Rand DE, Einarson BL, Lindstrom JM (1981) Mapping of surface structures of Electrophorus acetylcholine receptor using monoclonal antibodies. J Biol Chem 256:8635-8645

141. Trartos SJ, Seybold ME, Lindstrom JM (1982) Specificities pf antibodies to acetylcholine receptors in sera from myasthenia gravis patients measured by monoclonal antibodies. Proc Natl Acad Sci 79:188-192

142. Tzartos S, Langeberg L, Hochschwender S, Lindstrom J (1983) Demonstration of a main ummunogenic region on acetylcholine receptors from human muscle using monoclonal antibodies to human receptor. FEBS lett 158:116-118

143. Tzartos SJ, Sophianus D, Efthimiadis A (1985) Role of the main immunogenic region of acetylcholine receptor in myasthenia gravis. An Fab monoclonal antibody protects against antigenic modulation by human sera. J Immunol 134:2343-2349

144. Tzartos SJ, Sophianus D, Zimmerman K, Starzinski-Powitz A (1986) Antigenic modulation of human myotube acetylcholine receptor by myasthenic sera. Serum titer determines internalization rate. J Immunol 136:3231-3238

145. Tzartos S, Langeberg L, Hochschwender S, Swanson LW, Lindstrom J (1986) Characteristics of monoclonal antibodies to denaturated Torpedo and to native calf acetylcholine receptors: species, subunit and region specificity. J Neuroimmunol 10 : 235-253

146. Tzartos S, Hochschwender S, Vasquez P, Lindstrom J (1987) Passive transfer of experimental autoimmune myasthenia grawis by monoclonal antibodies to the main immunogenic region of the acetylchoiline receptor. J Neuroimmunol 15:185-194

147. Tzartos SJ, Kokla A, Walgrave SL, Conti-Tronconi BM (1988) Localization of the main immunogenic region of human muscle acetylcholine receptor to residues $67-76$ of the $\alpha$ subunit. Proc Natl Acad Sci 85:2899-2903

148. Vernet-der-Garabedian B, Morel E, Bach J-F (1986) Heterogeneity of antibodies directed against the a-bungarotoxin binding site on human acetylcholine receptor and severity of myasthenia gravis. J Neuroimmunol 12:65-74

149. Verschuuren JJCM, Bos GMJ, Majoor GD, De Baets MH, van Breda Vriesman PJC (1989) 'Spontaneous' myasthenia gravis in a rat after syngeneic bone marrow transplantation. Proceedings of '2nd conference on myasthenia gravis' p. 33 (abstract) 
150. Vincent A (1980) Immunology of acetylcholine receptors in relation to myasthenia gravis. Physiol Rev 60:756-824

151. Vincent A, Cull-Candy SG, Newsom-Davis J, Trautmann A, Molenaar PC, Polak RL (1981) Congenital myasthenia: end-plate acetylcholine receptors and electrophysiology in five cases. Muscle Nerve 4:306-318

152. Vincent $\mathbf{A}$, Whiting $\mathbf{P J}$, Schluep $\mathbf{M}$, Heidenreich $\mathbf{F}$, lang $\mathbf{B}$, Roberts $\mathbf{A}$, Willcox $\mathbf{N}$, Newsom-Davis J (1987) Antibody heterogeneity and specificity in myasthenia gravis. Ann N Y Acad Sci 505:106-120

153. Walker MB (1934) Treatment of myasthenia gravis with physostigmine. Lancet 1:12001201

154. Wekerle H, Hohlfeld R, Ketelsen U-P, Kalden JR, Kalies I (1981) Thymic myogenesis, T-lymphocytes and the pathogenesis of myasthenia gravis. Ann N Y Acad Sci 377:455-476

155. Whiting PJ, Vincent A, newsom-Davis J (1983) Acetylcholine recptor atitibody characteristics in myasthenia gravis. Fractionation of $\alpha$-bungarotoxin binding site antibodies and their relationship tp IgG subclass. J Neuroimmunol 5:1-9

156. Whiting PJ, Vincent A, Schluep M, Newsom-Davis J (1986) Monoclonal antibodies that distinguish between normal and denervated human acetylcholine receptor. $J$ Neuroimmunol 11:223-235

157. Wilson PT, Lentz TL, Hawrot E (1985) Determination of the primary amino acid sequence specifying the $\alpha$-bungarotoxin binding site on the $\alpha$-subunit of the acetylcholine receptor from Torpedo californica. Proc Natl Acad Sci 82:8790-8794

158. Woolf AL (1966) Morphology of the myasthenic neuromuscular junction. Ann N Y Acad Sci 135:35-56

159.Zacks SI, Bauer WC, Blumberg JM (1962) The fine structure of the myasthenic neuromuscular junction. J Neuropath Exp Neur 21:335-347 



ROLE OF ACETYLCHOLINE

RECEPTOR ANTIBODY COMPLEXES

IN MUSCLE IN EXPERIMENTAL AUTOIMMUNE MYASTHENIA GRAVIS

Jan J.G.M. Verschuuren, Yvo M.F. Graus, Ruud O.M. Theunissen, Peter J.C. van Breda Vriesman, Marc H. De Baets 



\section{Introduction}

In myasthenia gravis (MG) autoantibodies, attacking the nicotinic acetylcholine receptor $(\mathrm{AChR})$, are responsible for disturbing the neuromuscular transmission $(31,44)$; animal models of $M G$, experimental autoimmune myasthenia gravis (EAMG), produced by immunization by purified $\mathrm{AChR}$, are characterized by similar abnormalities as found in MG $(28,31)$.

In this disease disturbances in signal transmission at the neuromuscular junction are due to a reduction in number or malfunction of AChR's. In MG $(14,27,34)$ and EAMG $(25,29)$ the former has repeatedly been demonstrated. In man a reduction of $64 \%$ to $89 \%$ of $A C h R$ has been observed $(14,27,34)$, and analysis of carcasses of rats with chronic EAMG has shown the AChR content to be reduced to about one-third of normal $(25,29)$. Mechanisms, involved in this decrease of $A C h R$, probably are antigenic modulation by anti-AChR antibodies (28), and complement mediated lysis resulting in loss of postsynaptic folds and simplification of the postsynaptic membrane (12). Binding of anti-AChR antibodies could block the acetylcholine $(\mathrm{ACh})$ binding site $(6,20,24,42)$, or interfere with the cation channel function by allosteric changes in the AChR structure $(16,19,23,33)$. Finally, alterations of the postsynaptic membrane structure might disturb the optimal juxtaposition of ACh-release and AChR's (28), or differences in clinical susceptibility might be due to differences in the capability to compensate for the loss of AChR by increasing the production of AChR's $(1,9)$. Isotype of the anti-AChR antibodies do not appear to play an important role in the pathogenesis of MG $(21,38,45)$.

These additional immunopathological factors might indeed be important to explain the differences in clinical condition, as is shown by the fact that AChR loss by itself does not completely account for all differences in the clinical condition in chronic EAMG, since no good correlation between these two parameters was found $(2,3,5$, 34,43 ). Thus, in addition to a reduction of the safety factor by extensive AChR loss a further decrease in acetylcholine sensitivity of AChR's at the endplate might be due to other factors as mentioned above. It follows that in chronic EAMG the total amount of extractable AChR, which includes free $\mathrm{AChR}$ and antibody bound $\mathrm{AChR}$, might not be critical in determining the succes of neuromuscular transmission, but rather the amount of free AChR. To answer this question, detailed quantative analysis of the amount of AChR's complexed with antibodies in vivo is required. In man and rat variable amounts of AChR's, extracted from muscle biopsy or carcass respectively, can be shown to have antibody complexed to $\operatorname{AChR}(27,29)$. In rats (27) and in mice (4) the amount of antibody bound to AChR in muscle were found to parallel the severity of weakness, and comparing various rat strains it was reported that the amounts of AChR-antibody complexes (together with equal 
amounts of AChR loss) parallel the susceptibility for EAMG (3). Ultrastructural analysis, however, revealed that the amount of antibody bound to the postsynaptic membrane in MG patients or EAMG rats to be less in the more severe cases of $M G$ or EAMG $(13,39)$, and in mice no correlation between the fraction of $\mathrm{AChR}$ bound by antibody and the clinical condition of the animal was found (2). Moreover, in chronic EAMG a relation between titer and AChR antibody complexes was described $(4,8,32)$. In addition, it is known that in MG and EAMG antibody titers do not closely correlate with severity of disease, thus these observations question the role of AChR-antibody complexes $(15,24)$.

We report here the results of studying AChR-antibody complexes in large series of rats. Using an improved method for measuring AChR complexes in muscle in vivo, the relationship between AChR-antibody complexes and disease severity was analysed. From this study it can be concluded that far less AChR's are complexed in vivo than has been reported with other methods, and that by the use of detergent mediated extraction no relation between free muscle $A C h R$ and disease severity can be detected.

\section{Materials and methods}

\section{Animals}

Inbred female Lewis rats were obtained from our own breeding colony (Dept. of Experimental Animal Services of the University of Limburg). All animals were bred under specific pathogen free conditions.

Preparation of acetylcholine receptor

Acaetylcholine receptor (AChR) from the main electric organ of Torpedo californica (Pacific Biomarine, California, USA) was purified by affinity chromatography on Naja naja siamensis (Miami Serpentarium, Florida, USA) linked to sepharose-4B $(30,7)$. This preparation was used for immunizations and in radioimmunoassays (RIA) for the determination of anti-Torpedo AChR antibody titers (25).

Induction of chronic experimental autoimmune myasthenia gravis

At the age of 11 weeks rats were injected at the base of the tail with purified AChR from Torpedo californica in $0.1 \mathrm{ml}$ phosphate-buffered saline (PBS), emulsified in an equal volume of complete Freund adjuvant (CFA). 


\section{Clinical scoring}

Weight loss was used as a quantative measure of clinical illness in experimental autoimmune myasthenia gravis (EAMG) (22). In addition the animal's muscle strength was assessed by its ability to grasp and lift repeatedly a $300 \mathrm{~g}$ rack from the table, while suspended manually by the base of its tail for 30 seconds. Clinical scoring was based on the presence of spontaneous tremor, hunched posture of the animal, and strength and fatigability. Results were expressed as 0 (no obvious abnormalities), * (no abnormalities before testing, but decreased strength at the end), ++ (clinical signs present before testing, i.e. tremor, head down, hunched posture, weak grip upon testing), +++ (severe clinical signs before testing, no grip, moribund) (22).

\section{Assay of anti-rat AChR antibody titer}

Serum was obtained before immunization and afterwards at weekly intervals. Antirat AChR antibody concentration was measured by immunoprecipitation using ${ }^{125} \mathrm{I}-\alpha$-bungarotoxin (BT)-AChR as antigen (25). Crude extract of rat muscle AChR (approximately $0.6 \mathrm{nmol} / \mathrm{L})$ was labeled with ${ }^{125} \mathrm{I}-\alpha-\mathrm{BT}-\mathrm{AChR}\left(2 \times 10^{-9} \mathrm{M}\right)$ for a minimum of $4 \mathrm{hr} .{ }^{125} \mathrm{I}-\alpha-\mathrm{BT}-\mathrm{AChR}$ was incubated in a volume of $0.2 \mathrm{ml} \mathrm{PBS}$, containing $0.5 \%$ TRITON X-100 (Sigma / Brunschwig chemie bv, Amsterdam), and $0.02 \% \mathrm{NaN}_{3}$ (TRITON-X-100-PBS-NaN3) with $5 \mu$ l serum overnight at $4^{\circ} \mathrm{C}$. The resulting complexes were precipitated by addition of $100 \mu \mathrm{l}$ goat-anti-rat immunoglobulin (50\% ammoniumsulfate precipitate). After $4 \mathrm{hr}$ incubation at $4^{\circ} \mathrm{C}$, the samples were centrifuged for 3 min (Eppendorf centrifuge 5413, Merck, Hamburg) and the resulting pellet was washed once with $1 \mathrm{ml} 0.5 \%$ Triton-X-100-PBS$\mathrm{NaN}_{3}$. Radioactivity was counted in a gamma counter (Compugamma, Pharmacia $\mathrm{LKB}$, Woerden). The value for ${ }^{125} \mathrm{I}-\alpha-\mathrm{BT}-\mathrm{AChR}$ pelleted in the presence of normal rat serum $(5 \mu \mathrm{l})$ was subtracted from the assay value. The antibody titer was expressed as moles of ${ }^{125} \mathrm{I}-\alpha-\mathrm{B}$ T binding sites per liter.

\section{Measurements of $A C h R$ and $A C h R$-antibody complexes in rat muscle determined without washing}

The concentration of AChR in the rat carcasses was determined according to Lindstrom (25) with minor modifications. Each rat was anaesthetized with ether and bled from the abdominal aorta, the carcas was frozen on dry ice and stored at $-70^{\circ} \mathrm{C}$. For determination of $\mathrm{AChR}$ and $\mathrm{AChR}$-antibody complexes the carcasses were minced and homogenized in $250 \mathrm{ml} 10 \mathrm{mM}$ Na phosphate pH 7.5, $100 \mathrm{mM} \mathrm{NaN}_{3}$, $10 \mathrm{mM}$ iodoacetamide and $1 \mathrm{mM}$ PMSF (buffer A) in a blendor (Waring Products Division, New Hartford, USA). A sample of $20 \mathrm{~g}$ of the homogenate was centrifuged $(30,000 \mathrm{~g}, 30 \mathrm{~min}, \mathrm{~J}-21 \mathrm{~B}$ centrifuge, Beckman Instruments Nederland bv, Mijdrecht, The Netherlands) and the resulting pellet was resuspended in $15 \mathrm{ml}$ buffer A with additional $0.5 \%$ Triton X-100 (Sigma, St. Louis, USA). Extraction 
was performed for 60 min at $4^{\circ} \mathrm{C}$ on a shaker (SM, Bühler, Germany). After centrifugation $(30,000 \mathrm{~g}, 30 \mathrm{~min})$ the volume of the supernatant was measured. Aliguots of $5 \mathrm{ml}$ were labeled with $5 \mu 1{ }^{125} \mathrm{I}-\alpha-\mathrm{BT}\left(2 \times 10^{-6} \mathrm{M}\right)$ units with or without $10^{-3} \mathrm{M}$ acetylcholine and neostigmine-bromide overnight at $4^{\circ} \mathrm{C}$. Then $0.25 \mathrm{ml}$ (for determination of AChR content) of labeled extracts (both with and without an excess acetylcholine and neostigmine bromide) were incubated in triplicate with 5 $\mu \mathrm{l}$ of pooled high titer anti-AChR serum (50\% ammoniumprecipitate) or $1 \mathrm{ml}$ (for determination of AChR-antibody complexes) of labeled extracts were mixed in triplicate with normal rat serum. After again overnight incubation $100 \mu \mathrm{l}$ goat anti rat $\mathrm{IgG}$ was added and incubated for $4 \mathrm{hr}$ at $4^{\circ} \mathrm{C}$. After centrifugation for $3 \mathrm{~min}$ the pellet was washed once with $1 \mathrm{ml}$ phosphate buffered saline containing $0.5 \%$ Triton $\mathrm{X}-100$, and $0.02 \% \mathrm{NaN}_{3}$, pelleted again and counted in a gamma counter. The background values of the tubes containing acetylcholine / neostigmine were subtracted. The concentration of AChR or AChR-antibody complexes were expressed as moles of ${ }^{125}$ I- $\alpha$-BT binding sites/rat.

\section{Measurements of $A C h R$ and $A C h R$-antibody complexes in rat muscle determined with washing}

In order to remove unbound serum anlibody from muscle, a washing procedure was introduced prior to solubilization of $A C h R$. Five aliquots of $20 \mathrm{~g}$ rat muscle homogenate were taken, and depending on the experiment $1 \mathrm{ml}$ myasthenic serum (or normal rat serum) was added, and mixed with the homogenate for $20 \mathrm{sec}$ in an omni-mixer (Sorvall, Newtown, USA). After fifteen minutes incubation with myasthenic serum one aliquot was centrifugated and extraction was performed using buffer A containing $0.5 \%$ TRITON $\mathrm{X}=100$, as described above. The remaining 4 aliquots were washed 1 to 4 times respectively. For each washing procedure, the pellet obtained after centrifugation at $30,000 \mathrm{~g}$ for $30 \mathrm{~min}$ was resuspended in 200 $\mathrm{ml}$ buffer $\mathrm{A}$ and centrifuged. Extraction and determination of AChR and AChR-antibody complexes were performed as described above.

\section{Determination of anti-acetyllcholine binding site antibodies}

An $\alpha$-BT blocking assay was used to determine the presence of antibodies capable of blocking the acetylcholine binding site. Polyvinyl 96-well microtiter plates (Flow Laboratories Ltd / Amstelstad bv, The Netherlands) were coated with $50 \mu 1$ Torpedo AChR $(5 \mu \mathrm{g} / \mathrm{ml})$ for 1 hour at $37^{\circ} \mathrm{C}$. Plates were then incubated with PBS containing $0.5 \%$ bovine serum albumen and $0.5 \%$ Tween- 20 (Serva/Brunschwig chemie bv, Amsterdam, The Netherlands) (PBSA-Tw) for 30 minutes at room temperature. After washing three times with $\mathrm{H}_{2} \mathrm{O}$, containing $0.5 \%$ Tween $\left(\mathrm{H}_{2} \mathrm{O}-\mathrm{Tw}\right)$ serial dilutions in PBS (1/2 to 1/8192) at $50 \mu$ l per well were allowed to incubate overnight at room temperature. Next, without washing, $50 \mu \mathrm{l} \alpha$-BT labeled with ${ }^{125} \mathrm{I}$ was added at a previously determined limiting concentration ( $2 \mathrm{pmol} / \mathrm{ml}$ ). After incuba- 
tion for 4 hours at room temperature the plates were whed 3 times with PBS, containing $0.5 \%$ TRITON-X100. Radioactivity bound to the wells was counted in a gamma counter (Compugamma, Pharmacia LKB, Woerden, the Netherlands). The percentage inhibiton was calculated as follows:

(1 [Average cpm of duplicate wells with ${ }^{125} \mathrm{I}-\alpha-\mathrm{BT}$ in the presence of putative inhibiting sera] / [Average cpm of duplicate wells in which ${ }^{125} 1-\alpha-B$ - were tested in presence PBS]) $\times 100$

\section{Removal of unbound serum antibodies from muscle}

To determine the amount of buffer needed for optimal removal of remaining blood, the effectiveness of flushing was investigated in an EAMG rat which had received ${ }^{125}$ I-labeled IgG.

Thus, $30 \mu \mathrm{g}{ }^{25} \mathrm{I}$ labeled $\left(32.10^{6}\right.$ counts/min per $\left.\mu \mathrm{g}\right)$ rat $\mathrm{IgG}$ was administred into the tail vene. Six hours later the rat was anaesthesized using ether (Diethylether, Merck, Darmstadt), and immobilized on a cork dissection board. The aorta was located, ligated just caudal from the diaphragm and a teflon catheter connected to an infusion system was placed in position in the aorta, connected to a $50 \mathrm{ml}$ syringe filled with Collins' buffer ( $42.5 \mathrm{mM} \mathrm{K} 2 \mathrm{HPO}_{4} .3 \mathrm{H}_{2} \mathrm{O}$, $15.1 \mathrm{mM} \mathrm{KH}_{2} \mathrm{PO}_{4}, 15.0 \mathrm{mM}$ $\mathrm{KCl}, 10 \mathrm{mM} \mathrm{NaHCO}, 38 \mathrm{mM} \mathrm{MgSO}_{4} .7 \mathrm{H}_{2} \mathrm{O}, 68 \mathrm{mM}$ glucose) $\mathrm{pH} 7.38$ containing $5 \%$ BSA. The right iliacal communis artery and vene were ligated, and the left iliacal communis vene was perforated, and subsequently the rat was killed by high dose ether. By manually applied pressure the blood vessels were flushed, and after each $20 \mathrm{ml}$ fraction a muscle biopsy was taken from both legs. Radioactivity in the muscle biopsies was measured and expressed as counts per gram muscle tissue.

After flushing with $80 \mathrm{ml}$ Collins' buffer no further decline in radioactivity could be measured. Next, using this protocol left hindlimbs of 3 EAMG rats were flushed, and both legs were separately frozen on dry ice and stored at $-70^{\circ} \mathrm{C}$. AChR content and AChR-antibody complexes were determined with and without washing, in both perfused an non-perfused limbs

Statistical analysis

For statistical analysis the $\mathrm{t}$ test and Wilcoxon-Rank test were used (40). 


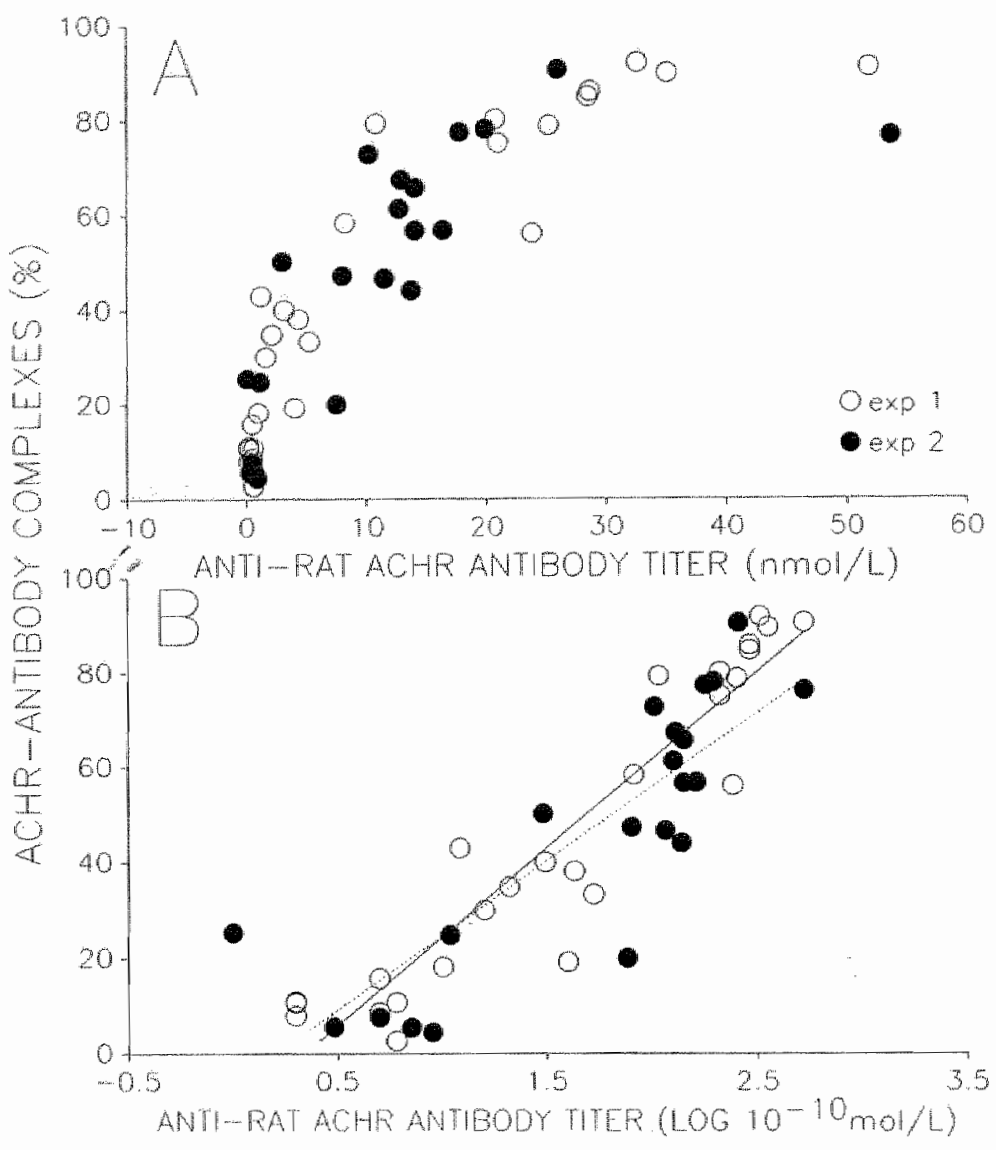

FIGURE 2.1 Correlation between anti-rat antibody titer and AChR-antibody complexes in muscle. Anti-rat antibody titer and AChR-antibody complexes in muscle of respectively 26 (exp1) and 21 (exp2) rats were determined. (A): The amount of antibody complexed to AChR in muscle is directly proportional to the serum anti-rat AChR antibody titer. (B): Linear correlation between the two variables is demonstrated after log-transformation of the anti-rat $A C h R$ antibody titer $(r=0.876, p<0.001$, respectively $r=0.703, p<0.001$ for experiment $I$ and 2). 


\section{Results}

\section{Correlation between anti-rat $\mathrm{AChR}$ titer and $\mathrm{AChR}$-antibody complexes found in muscle}

In order to analyse the relation between the anti-rat $\mathrm{AChR}$ antibody titers and the disease severity, the antibody titers and $\mathrm{AChR}$ content of the corresponding carcasses in two groups of rats (26 respectively 21 rats) was analysed. Rats were killed six weeks after immunization with Torpedo $A C h R$, and anti-rat $A C h R$ antibody titers, AChR content and AChR-antibody complexes in the carcasses were determined. AChR-antibody complexes were found to correlate closely with anti-rat AChR antibody titers in both experiments (Fig 2.1). After logaritmic transformation of the anti-rat AChR antibody titer a linear correlation with AChR-antibody complexes was found (experiment 1 and $2: \mathrm{r}=0.876, \mathrm{p}<0.001, \mathrm{n}=26$, respectively $\mathrm{r}=$ $0.703, p<0.001, \mathrm{n}=21)$.

\section{In vitro binding of anti-rat $\mathrm{AChR}$ antibodies during extraction of $\mathrm{AChR}$ from normal muscles}

It was investigated whether $\mathrm{ACh} R$-antibody complex formation in muscle could be due to in vitro binding of antibodies during the extraction procedure. Therefore, muscle homogenates of two normal rat carcasses were prepared. Five aliqots $(20 \mathrm{~g})$ of the muscle homogenate were mixed with with $1 \mathrm{ml}$ serum of a Torpedo- $A \mathrm{ChR}$ immunized rat obtained at six weeks after immunization (anti-rat AChR titer 27.6 $\mathrm{nmol} / \mathrm{L}$ ). It was calculated that the amount of serum added to the homogenate contained anti-rat AChR antibodies exceeding the content of AChR by a factor 7 . $\mathrm{AChR}$ and $\mathrm{AChR}$-antibody complexes were determined with and without washing. Without washing all of the $\mathrm{AChR}(100 \%$, respectively $106 \%)$ in the muscle homogenate was complexed with antibody (Fig 2.2a, b). Washing the muscle homogenate before extraction was capable of diminishing the complexes to $9 \%$, respectively $11 \%$ of the amount of $A C h R$ content. After two washes no further decline in AChR-antibody complexes could be achieved. AChR content itself was not affected by washing. In muscle homogenates mixed with normal rat serum maximal $0.1 \%$ complexes were found (not shown). 


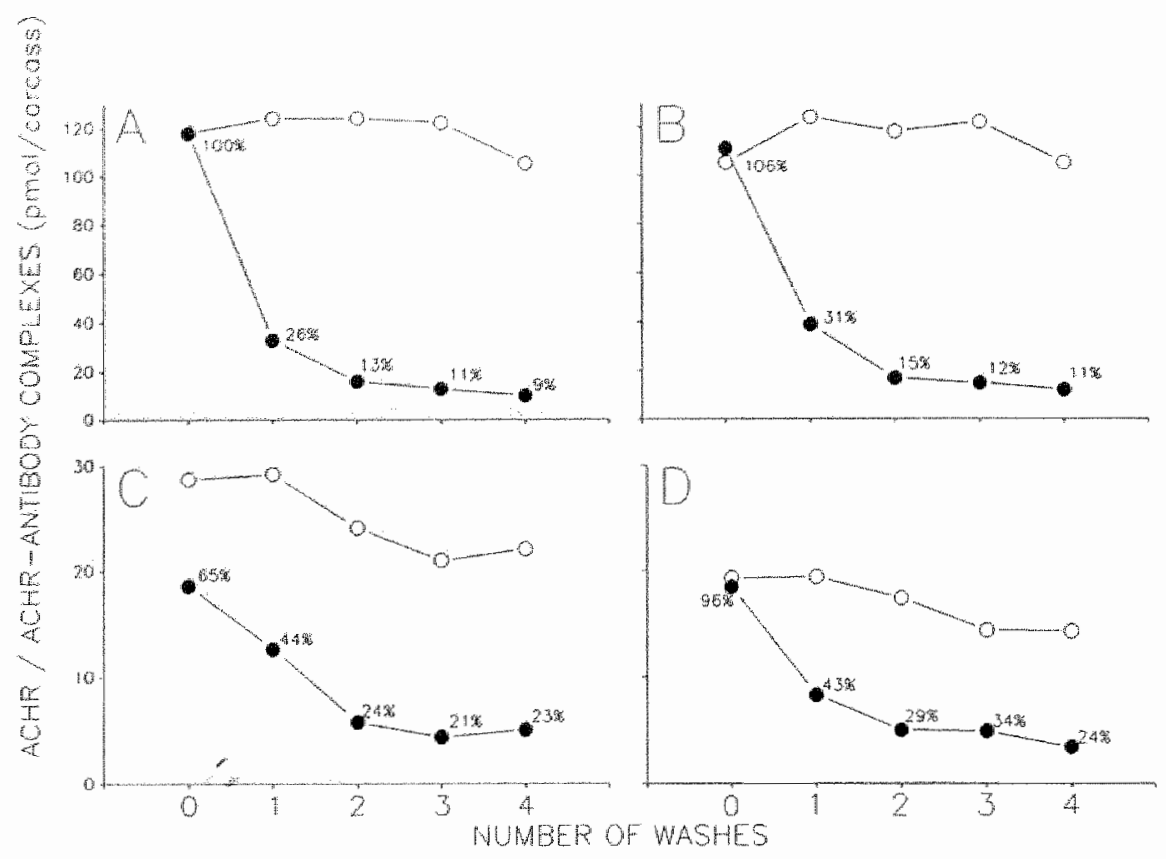

FIGURE 2.2 AChR-antibody complex formation can be prevented by washing of the muscle homogenate prior to solubilization of the AChR. $(\mathbf{A}, \mathbf{B})$ : EAMG sera were added to 2 normal carcasses, and AChR-antibody complexes were shown to decrease with the number of washing. (C,D): Two EAMG carcasses were treated similarly, and also showed reduction of the amount of $A C h R$-antibody complexes due to repeated washing. Anti-rat AChR antibody titers were $3.5 \mathrm{nmol} / \mathrm{L}$ (C) and $12 \mathrm{mmol} / \mathrm{L}$ (D). AChR content (open circles) and AChR-antibady complexes (closed circles) are expressed as pmol/carcass. Percentages of AChR-antibody complexes are indicated as percentages of the corresponding amount of $A C h R$.

\section{In vitro binding of anti-rat $A C h R$ antibodies during extraction of $A C h R$ from myasthenic muscles}

It was investigated if washing had similar effects on muscle homogenates of 2 EAMG rats. Anti-rat AChR titers of these rats were respectively 3.5 and $12 \mathrm{nmol} / \mathrm{L}$. The carcasses, obtained six weeks after immunization, were homogenized and aliquots $(20 \mathrm{~g})$ were assayed without washing, or after 1 to 4 washes. Washing 4 times diminished AChR-antibody complexes, to 23 respectively $24 \%$ (Fig $2.2 \mathrm{c}$, d). The largest decrease of complexes was reached in the first two washes. From the amount of $\mathrm{AChR}$ found in the carcass, it was calculated that at six weeks after immunization these rats should have had a 13 respectively 2 fold excess of circulating anti-rat AChR antibodies in comparison with the amount of AChR in muscle. 


\begin{tabular}{llrrrrr}
\hline Group & \multicolumn{2}{l}{$\begin{array}{l}\text { Weight } \\
\text { Before } \\
\text { immunization }\end{array}$} & Week 4 & Week 6 & Carcass & $\begin{array}{l}\text { Titer (nmol/L) } \\
\text { Anti-rat AChR }\end{array}$ \\
\hline A & Mean & 197 & 209 & 164 & 92 & 19.0 \\
& SD & 6 & 6 & 21 & 16 & 16.9 \\
& Mean & 200 & 218 & 222 & 91 & 16.4 \\
& SD & 7 & 8 & 5 & 17 & 10.4 \\
\hline
\end{tabular}

TABLE 2.1. Weight and anti-rat AChR antibody titer EAMG rats. Results of 10 rats immunized with $20 \mu \mathrm{g}$ Torpedo AChR. Five rats (A) showed more than $10 \%$ weight loss at six weeks after immunizarion and grade +++ clinical signs of $E A M G$, and 5 rats $(B)$ did.

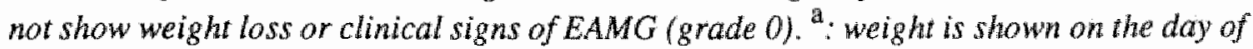
the immunization, and at 4 and 6 weeks afterwards; also the weight of the carcass, obtained at six weeks afterwards, was measured. " anti-rat AChR antibody titer determined 6 weeks after immunization.

\section{Comparison between clinical illness and content of free AChR in muscle}

Using our modified protocol for determination of $\mathrm{AChR}$ and $\mathrm{AChR}$-antibody complexes in muscle, it was tested whether a difference in free $A C h R$, i.e. not complexed with antibody, could be detected between severely myasthenic and clinically unaffected EAMG rats.

Five AChR immunized rats were selected for weight loss of more than $10 \%$ (mean $\pm S D: 22 \pm 8.4 \%$, range $11-34 \%$ ) and grade +++ clinical illness at six weeks after immunization (group A). Age-matched controls were selected which had similar weights before immunization with Torpedo $A C h R$, but did not develop signs of experimental autoimmune myasthenia gravis (EAMG) during six weeks after immunization or Ioss of weight (group B) (Table 2.1). AChR content and AChR-antibody complexes were determined in aliquots of muscle homogenates without washing and after three washes.

Mean AChR loss determined in the carcass at six weeks after immunization without or with washing was respectively $51 \pm 8 \%$ and $60 \pm 7 \%$ in group $A$, and $57 \pm 7 \%$ and $70 \pm 4 \%$ (mean \pm SD) in group B. (Table 2.2). The amount of AChR-antibody complexes correlated well with anti-rat $\mathrm{AChR}$ antibody titers, before washing $(r=0.861, p<0.01)$ (Fig 2.3a), as well as after 3 washes $(r=0.847, p<0.01)$ (Fig 2.3b). 


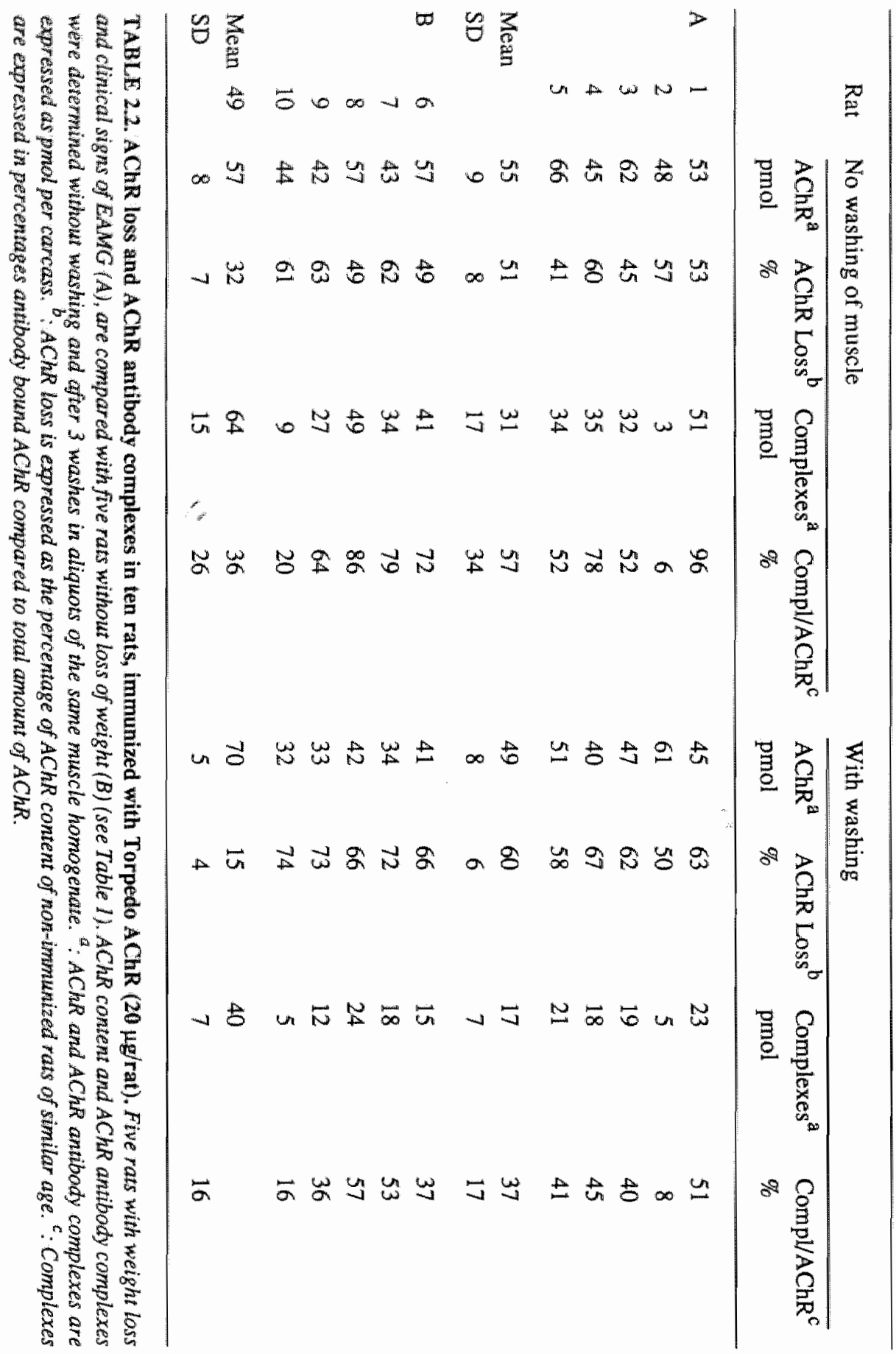




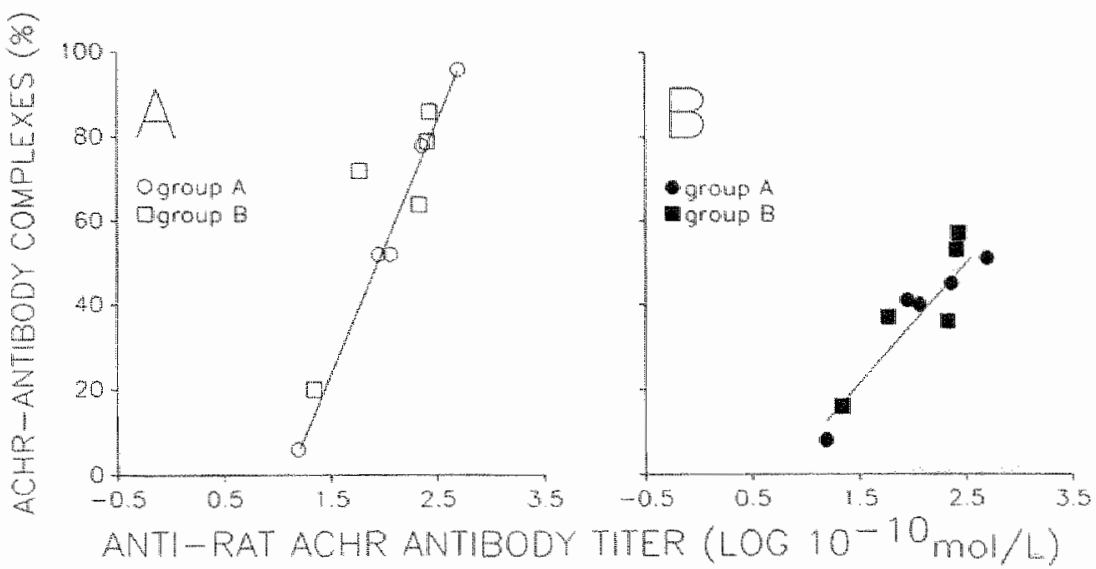

FIGURE 2.3 Washing of muscle homogenates diminishes AChR-antibody complexes, but the amount of complexes correlates with anti-rat $A C h R$ antibody titer and not with clinical condition. A: Before washing the amount of antibody bound AChRs is proportional to anti-rat AChR antibody titers $(r=0.861, p<0.01)$. Amounts of complexes in carcasses of rats withour clinical signs (open squares, regression line indicated by dotted line) and with clinical signs of EAMG (open circles, solid line) are not significantly different.

B: After washing AChR-antibody complexes correlate with anti-rat AChR titer $(r=0.847$, $p<0.01$ ). Amounts of complexes in carcasses of rats without clinical sigms (filled squares, dotted line) and with clinical signs of EAMG (filled circles, solid line) are not different.

Regression lines are indicated for each group separately, rats with signs of EAMG are indicated by solid lines, without signs by dashed lines.

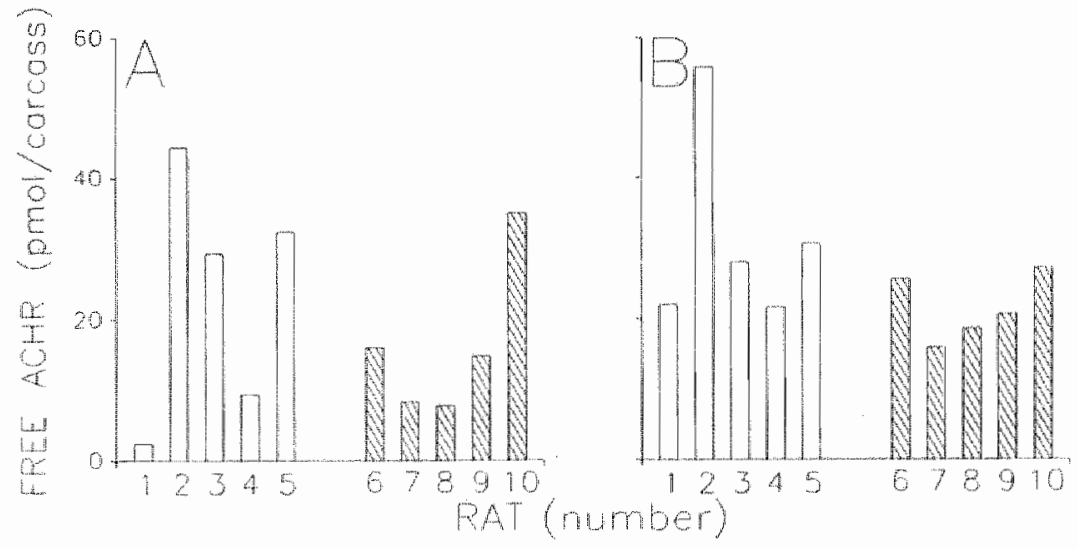

FIGURE 2.4 No differences in free AChR, expressed as pmol/carcass, between carcasses of rats with signs of EAMG (open bars) and without signs (hatched bars), as determined without a washing procedure (A) and after washing (B). 


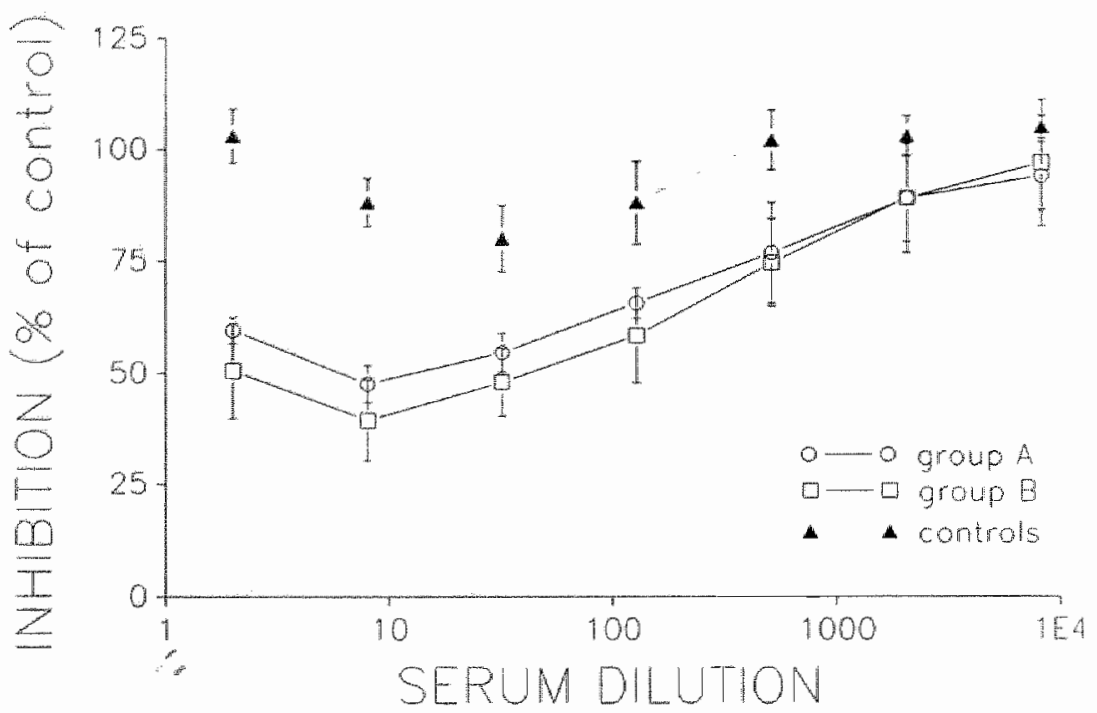

FIGURE 2.5 Anti- $\alpha$-bungarotoxin binding site antibodies. Inhibition of $\alpha$-bungarotoxin binding to Torpedo AChR by rat serc. Microtiter plated were coated with Torpedo AChR (5 $\mu \mathrm{g} / \mathrm{ml}$ ) and overnight sera were incubated. Next, without washing $50 \mu \mathrm{l} \alpha-B T$ labeled with ${ }^{125} I$ was added, and bound radioactivity was counted. Serum dilutions (1/2 to 1/8192) from control, PBS-CFA immunized, rats (closed triangles) were compared to sera from $A C h R-C F A$ immunized rats with signs of EAMG (open circles) and sera from AChR-CFA immunized rats without signs (open squares). Values are indicated as mean standard deviation.

Without washing the amount of free AChR did not differ between group A (24 \pm 17 $\mathrm{pmol} / \mathrm{carcass})$ and $\mathrm{B}(17 \pm 11 \mathrm{pmol} / \mathrm{carcass})$. After the third wash the amount of free AChR was not different between both groups ( $32 \pm 14$, respectively $22 \pm 5$ pmol/carcass). Thus, tats showing weightloss and severe symptoms of EAMG, did not have lower numbers of free AChR. For example, the highest amount of free AChR was found in a rat (no. 2) which had developed the largest weight loss (34\%) (Fig 2.4)

\section{Comparison between clinical illness and blocking antibodies}

Sera from both group A and B were tested for their capacity to inhibit the binding of $\alpha$-bungarotoxin ( $\alpha-B T)$ to Torpedo AChR. All rats, immunized with AChR, showed a significant blocking of $\alpha$-BT binding, as compared to control rats, immunized with adjuvant (Fig 2.5). No differences, however, were found between the 
group of EAMG rats with severe weightloss (maximal inhibition $52 \pm 4 \%$, range $48-58 \%$ ) and the clinically unaffected $E A M G$ rats (mean $\pm S D: 61 \pm 9 \%$, range $51-76 \%$ ).

\section{Contribution of serum antibodies to in vitro AChR-antibody complex formation}

It was questioned to which degree serum anti-rat $\mathrm{AChR}$ antibodies contribute to the formation of in vitro $\mathrm{AChR}$-antibody complexes. Therefore, one hindlimb was flushed with medium to remove the intravascular antibodies, and AChR content and AChR-antibody complexes were determined in hindlimb muscles and compared to the non-flushed leg.

After injecting ${ }^{125}$ I-labeled $\mathrm{IgG}$ into an EAMG rat, its was found that after perfusion of the iliacal artery with $80 \mathrm{ml}$ no further decline of radio activity (maximal $80 \%$ ) could be expected (Fig 2.6). Next, left hindlimbs of 3 rats, with EAMG were flushed and $\mathrm{AChR}$ contents and the amount of AChR-antibody complexes were compared to those found in the non-flushed legs, both determined with and without washing.

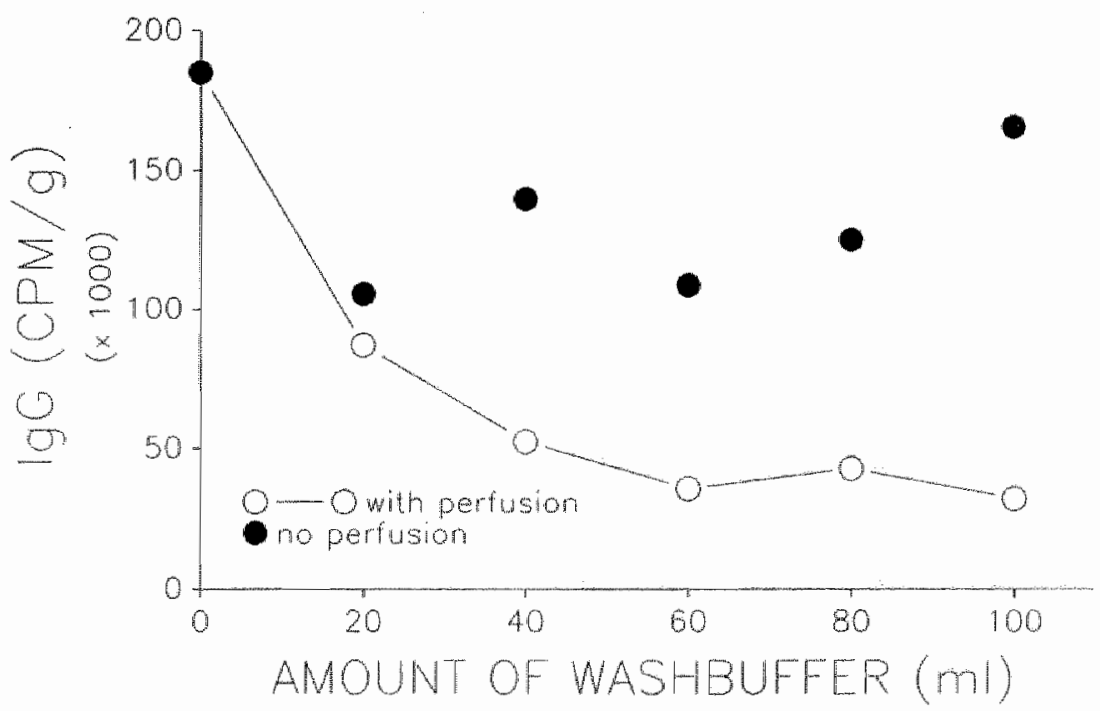

FIGURE 2.6 Effect of in vivo perfusion of IgG content of muscle. Decrease of ${ }^{125}$ I-labeled IgG content of perfused hindlimb of a EAMG rat (open circles), compared to the non-perfused hindlimb (closed circles). Amount of medium used to flush the hindlimb vessels is indicated at the X-axis. At each point indicated at the X-axis the amount of ${ }^{125} I$-labeled $1 g G$ in a muscle biopsy was determined, and expressed as counts per gram muscle tissue. 

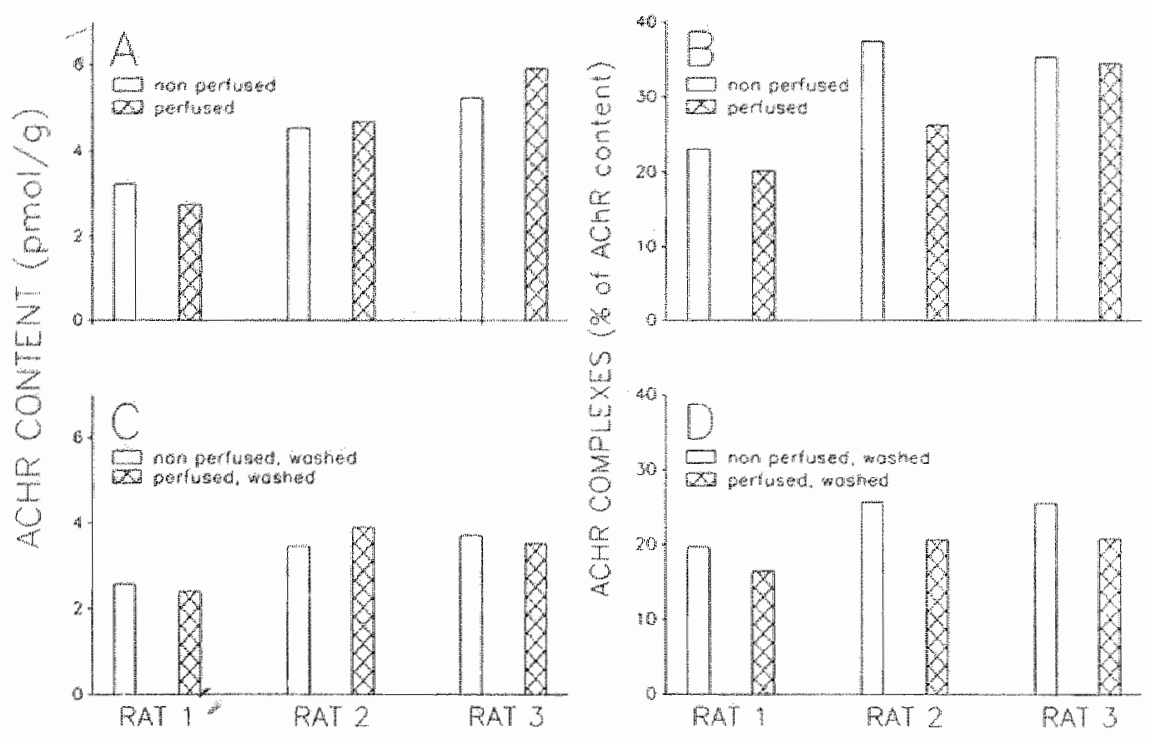

FIGURE 2.7 Intravascular IgG antibody contributes little to in vitro AChR-antibody complex formation. Effect of in vivo perfusion of muscle blood vessels on the amount of AChR-antibody complexes. In three EAMG rats, as indicated at the $X$-axis, left hindlimbs were flushed (hatched bars), and right hindlimbs were not (open bars). AChR and AChR-antibody complexes were determined without $(\mathbf{A}, \mathbf{B})$, and with washing $(\mathbf{C}, \mathbf{D})$. The amount of AChR found in these legs, expressed as pmol per gram muscle tissue, was similar in all three rats $(\mathbf{A}, \mathbf{C})$. The amount of $A C h R$-antibody complexes, expressed as percentage of $A C h R$, was similar in both hindlimbs before and after washing (B,D).

The AChR content found in corresponding hindlimbs, without and with perfusion, was comparable (respectively, 3.2 and $2.7,4.5$ and $4.7,5.2$ and $5.9 \mathrm{pmol} / \mathrm{g}$ muscle) (Fig 2.7a). The percentage of AChR's bound with antibody was not significantly different between the non-flushed and flushed legs of all three EAMG rats. Without and with perfusion, respectively 23 and $20 \%, 37$ and $26 \%$ and 35 and $34 \%$ AChRantibody complexes were found (Fig 2.7b). Additional washing of the muscle homogenates resulted in some loss of $\mathrm{AChR}$ compared to the amount of $\mathrm{AChR}$ found before washing (Fig 2.7c), but still the percentage of complexes further decreased, while the differences between perfused and non-perfused hindlimbs remained the same (Fig 2.7d). 


\section{Discussion}

In EAMG a highly significant correlation between anti-rat AChR titer and the percentage of $\mathrm{AChR}$ complexed with antibody was found, when these complexes were determined without removing an excess of unbound antibodies by washing the muscle homogenate. Similar observations were made in chronic EAMG in rats (8), and using passive transfer of MG serum to mice (32). In addition, we showed that anti-AChR antibodies were able to bind the AChR in vitro during its extraction from muscle, and that the formation of these immune complexes can be prevented by washing muscle homogenates before extraction of $\mathrm{AChR}$ with detergent.

In vitro formation of additional AChR-antibody complexes is inherent to the assay procedure, which consists of two steps. First, the carcass is minced, homogenized and dissolved in buffer. During this phase AChR is still bound to membranes and can be precipitated by centrifugation. Thereafter, the muscle tissue is dissolved in buffer containing detergent, which solubilizes the $\mathrm{AChR}$ (and thus it can no longer be precipitated by centrifugation). Until it is solubilized the AChR is poorly accessible for antibodies from the serum or extravascular compartment, because it is possible to prevent immune complex formation by washing before detergent is added. During extraction not only extracellular epitopes, but also intracellular and intramembraneous parts of the AChR become freely exposed to antibodies.

Therefore, two explanations for our observation of in vitro formation of AChR-antibody complexes can be put forward. First, solubilization increases the accessibility of the extracellular epitopes of the AChR, and additional anti-rat $\mathrm{AChR}$ antibodies will bind to these epitopes. On the other hand, newly exposured intra-membraneous and cytoplasmatic epitopes are able to bind antibodies which result in an increased number of complexes. In EAMG antibodies to highly immunogenic cytoplasmatic epitopes are present $(10,36)$, because this disease is induced by immunization with solubilized AChR (31).

The anti-AChR antibodies binding in vitro most likely consist of antibodies present in the extravascular compartment and from blood remaining in the smaller vessels, since not all the blood can be removed by exsanguination or, as we demonstrated, by flushing of the blood vessels with buffer. The amount of anti-rat AChR antibody in the serum of rats with chronic EAMG is present in 2 to 13 fold excess in comparison to the total muscle AChR, similarly as has been found before (29), thus small amounts of serum or extravascular fluids remaining in muscle in close contact with the AChR's, before detergent extraction, could be sufficient for a considerable amount of additional immunecomplex formation in vitro. Unexpectedly, the difference in amount of $\mathrm{AChR}$-antibody complexes found in flushed versus non- 
flushed muscles was maximally $11 \%$, while the flushing experiment using radiolabeled $\operatorname{lgG}$ indicated that $80 \%$ of the $\operatorname{IgG}$ could be removed by flushing. These results indicate that the $\lg G$ present in the extravascular compartment is more important for the in vitro binding of antibodies to the AChR than the serum fraction of antibodies remaining in the blood vessels.

Several reports suggest that the reduction of AChR's alone does not entirely explain the severity of symptoms in MG (34) or EAMG $(3,27,18)$. This can also be illustrated by the fact that 50-60\% reduction of junctional AChR's has been found in polymyositis patients, without symptoms of MG (35). Additional antibody mediated disturbances of AChR function include inhibition of AChR channel function (46), and immunopharmacological blockade of the AChR by antibodies against the ACh binding site (6).

The possible role of AChR-antibody complexes was tested using our modified assay. It was hypothesized that the difference of about $13 \%$ between the amount of AChR-antibody somplexes found in normal carcasses, to which myasthenic serum was added in witro, and the myasthenic carcasses might be due to the in vivo binding of antibodies. From these data the amount of free AChR, not bound by antibody, can be calculated, and this amount of free AChR might directly correlate with the clinical condition of the animal (27). Clinically myasthenic rats would expected to have less free AChR than clinically unaffected animals. In testing this hypothesis it was found that, although washing considerably influenced the amount of free AChR content, no differences were found between the rats with and without symptoms of EAMG. Thus, in contrast to previous findings $(3,27)$ no correlation between clincal condition and AChR-antibody complexes could be found.

On the other hand, antibodies blocking the acetylcholine binding site might be responsible for the differences in clinical condition. Inhibition of $\alpha$-BT binding was found in all animals to the same extent as has been reported previously (6), but it did not correlate with the clinical condition of the rats. Thus, pharmacological blockade of remaining AChR does not appear to be an important factor for the explanation of differences in clinical condition. Previously, antibodies of this specificity were also found in EAMG (6), and MG (20), but studies on the correlation of this subset of anti-AChR antibodies and clinical condition showed varying results $(11,24,42)$.

Although not significant, there was a tendency for the rats showing clinical illness to have a higher content of total or free AChR than the rats without symptoms. This might indicate that severely myasthenic rats have functionally denervated muscle fibers, which express some extrajunctional AChR like in passive, acute EAMG (26). These extrajunctional AChR's could compensate for the loss of AChR, and mask the AChR loss at the neuromuscular junction. Some indications for denervation in MG have been found (17), suggesting the compensatory formation of extrajunc- 
tional AChR. However, another study could not detect extrajunctional AChR's (37). Moreover, a considerable overlap in AChR content of the neuromuscular junction was found between severe and mild MG patients (34), using a method which could not be biased by extrajunctional AChR. Therefore, it is unlikely that the lack of difference in AChR content between rats with severe EAMG and those without symptoms can be explained by the presence of extrajunctional $\mathrm{AChR}$.

In conclusion, we improved the method for determination of AChR and AChR-antibody complexes in muscle homogenates using detergent. Results indicate that far less antibody complexes are present in myasthenic muscle, than previously has been reported. Using this method no differences in free $A C h R$ were found between rats with clinical signs of EAMG and rats without symptoms. In addition, also blocking antibodies did not explain the differences in clinical condition. Therefore, on one hand these results suggest that, in addition to a large amount of AChR loss, non-immunological parameters (e.g. AChR turnover) determine susceptibility for the development of clinical signs, although it might be questioned whether the differences between individuals of the same inbred strain would be that large. On the other hand, not the absolute quantity of AChR or free AChR found at the endplates, but rather the direct effects on channel function of the AChR by antibodies or the resulting structural alterations at the end-plate might determine the quality of neuromuscular transmission.

\section{Acknowledgments}

We wish to thank Mieke Henfling for excellent technical assistance, and the Beatrix foundation and the Nederlandse organisatie voor Wetenschappelijk Onderzoek (NWO) for their financial support. 


\section{References}

1. Asher O, Neumann D, Fuchs S (1989) Increased levels of acetylcholine receptor mRNA comrelate with experimental autoimmune myasthenia gravis. Proceedings of 2 nd European conference on myasthenia gravis p. 18 (abstract)

2. Berman PW, Heinemann SF (1984) Antigenic modulation of junctional acetylcholine receptor is not sufficient to account for the development of myasthenia gravis in receptor immunized mice. J Immunol 132:711-717

3. Buesecker G, Koffer D (1988) Resistance to experimental autoimmune myasthenia grawis in genetically inbred rats. Association with decreased amounts of in situ acetylcholine receptor-antibody complexes. J Immunol 140:3406-3410

4. Christadoss P, Lennon VA, Krco CJ, Lambert EH, David CS (1981) Genetic contro! of autoimmunity to acetylcholine receptors Role of Ia molecules. Ann N Y Acad Sci $377: 258-276$

5. Christadoss P, Lindstrom J, Munro S, Talal N (1985) Muscle acetylcholine receptor loss in murine experimental autoimmune myasthenia gravis: correlated with cellular, humoral and clinical responses. J Neuroimmunol 8:29-41

6. Claudio $\mathbf{T}$, Raftery MA (1980) Inhibition of $\alpha$-bungarotoxin binding to acetylcholine receptors by antisera from animals with experimental autoimmune myasthenia gravis. $J$ Supramol Structure 14:267-279

7. De Baets MH (1984) Autoimmunity to cell surface receptors. Immunopathology of acetylcholine receptors in experimental autoimmune myasthenia gravis in the rat. Thesis, BV Leiter-Nypels, Maastricht, p. 149-150

8. De Baets MH, Einarson B, Lindstrom JM, Weigle WO (1982) Lymphocyte activation in experimental autoimmune myasthenia gravis. J Immunol 128:2228-2235

9. De Baets MH, van Breda Vriesman PJC (1985) Autoïmunity to cell membrane receptors. Surv Synth Pathol Res 4:185-215

10. De Baets MH (1988) Specificities of autoantibodies in autoimmune receptor diseases. Immunol Res 7:218-231

11. Drachman DB, Adams RN, Josifek LF, Self SG (1982) Functional activities of autoantibodies to acetylcholine receptors and the clinical severity of myasthenia gravis. New Engl J Med 307:769-775

12. Engel AG, Tsujihata M, Lindstrom JM, Lennon VA (1976) The motor end-plate in myasthenia gravis and in experimental autoimmune myasthenia gravis. A quantative ultrastructural study. Ann N Y Acad Sci 274:60-79

13. Engel AG, Sahashi K, Fumagalli G (1981) The immunopathology of acquired myasthenia gravis. Ann N Y Acad Sci 377:158-174

14. Fambrough DM, Drachman DB, Satyamurti $\mathbf{S}$ (1973) Neuromuscular junction in myasthenia gravis: decreased acetylcholine receptors. Science 182:293-295

15. Fuchs S, Nevo D, Tarrab-Hazdai $\mathbf{R}$ (1976) Strain differences in the autoimmune response of mice to acetylcholine receptors. Nature 263:329-330

16. Heinemann S, Bevan S, Kullberg R, Lindstrom J, Rice J (1977) Modulation of acetylcholine receptor by antibody against the receptor. Proc Natl Acad Sci 74:3090-3094 
17. Hilton-Brown $\mathbf{P}$, Sů̊lberg $\mathbf{E V}$, Osterman PO (1982) Signs of reinnervation in myasthenia gravis. Muscle Nerve 5215-221

18. Hohlfeld R, Sterz R, Kalies I, Wekerle H, Peper K (1983) Experimental myasthenia gravis: lack of correlation between the autoantibody titer and the reduction of acetylcholine-controlled ionic channels measured at functioning endplates. Muscl Nerve 6:160163

19. Karlin A, Holtzman E, Valderrama R, Damle V, Hsu K, Reyes F (1978) Binding of antibodies to acetylcholine receptors in Electrophorus and Torpedo electroplax membranes. J Cell Bioll 76:577-592

20. Lefvert AK, Bergstrom K (1978) Acetylcholine receptor antibody in myasthenia gravis: purification and characterization. Scand J Immunol 8:525-533

21. Lefvert AK, Cuénoud S, Fulpius BW (1981) Binding properties and subclass distribution of anti-acetylcholine receptor antibodies in myasthenia gravis. I Neuroimmunol $1: 125-135$

22. Lennon VA, Lindstrom JM, Seybold ME (1975) Experimental autoimmune myasthenia gravis: a model of myasthenia gravis in rats and guinea pigs. I Exp Med 141:1365-1375

23. Lindstrom JM, Lennon VA, Seybold ME, Whittingham S (1976) Experimental autoimmune myasthenia gravis and myasthenia gravis: biochemical and immunochemical aspects. Ann N Y Acad Sci 274:254-274

24. Lindstrom JM, Seybold ME, Lennon VA, Whittingham $\mathbf{S}$, Duane DD (1976) Antibody to acetylcholine receptor in myasthenia gravis. Neurology 26:1054-1059

25. Lindstrom JM, Einarson BL, Lennon VA, Seybold ME (1976) Pathological mechanisms in experimental autoimmune myasthenia gravis. I. Immunogenicity of syngeneic muscle acetylcholine receptor and quantative extraction of receptor and antibody-receptor complexes from muscles of rats with experimental autoimmune myasthenia gravis. J Exp Med 144:726-738

26. Lindstrom JM, Engel AG, Seybold ME, Lennon VA, Lambert EH (1976) Pathological mechanisms in experimental autoimmune myasthenia gravis. II. Passive transfer of experimental atuoimmune myasthenia gravis in rats with anti-acelylcholine receptor antibodies. J Exp Med 144:739-753

27. Lindstrom JM, Lambert EH (1978) Content of acetylcholine receptor antibodies bound to receptor in myasthenia gravis, experimental autoimmune myasthenia gravis, and Eaton-Lambert syndrome. Neurology 28:130-138

28. Lindstrom I (1979) Autoimmune response to acetylcholine receptors in myasthenia gravis and its animal model. Adv Immunol 27:1-50

29. Lindstrom J, Einarson B (1979) Antigenic modulation and receptor loss in experimental autoimmune myasthenia gravis. Muscle Nerve 2:173-179

30. Lindstrom J, Anholt R, Einarson B, Engel A, Osame M, Montal M (1980) Purification of acetylcholine receptors, reconstitution into lipid vesicles, and study of agonist-induced cation channel regulation. J Biol Chem 255:8340-8350

31. Lindstrom J, Shelton D, Fujii Y (1988) Myasthenia gravis. Adv Immunol 42:233-284

32. Mossman S, Vincent A, Newsom-Davis J (1988) Passive transfer by immunoglobulins: lack of correlation between $A C h R$ with antibody bound, acetylcholine receptor loss and transmission defect. J Neurol Sci 84:15-28 
33. Patrick J, Líndstrom J, Cupp B, McMillan J (1973) Studies on purified eel acetylcholine receptor and anti-acetylcholine receptor antibody. Proc Natl Acad Sci 70:3334-3338

34. Pestronk A, Drachman DB, Self SG (1985) Measurement of junctional acetylcholine receptors in myasthenia gravis: clinical correlates. Muscle Nerve 8:245-251

35. Pestronk A, Drachman DB (1985) Polymyositis: reduction of acetyllcholine receptors in skeletal muscle. Muscle Nerve 8:233-239

36. Ratnam M, Nguyen DL, Rivier J, Sargent PB, Lindstrom J (1986) Transmembrane topography of nicotinic acetylcholine receptor: immunochemical tests contradict theoretical predictions based on hydrophobicity profiles. Biochemistry 25:2633-2643

37. Ringel SP, Bender AN, Engel WK (1976) Extrajunctional acetylcholine receptors. Arch Neurol 33:751-758

38. Rodgaard A, Nielsen FC, Djurup R, Somnier F, Gammeltoft $\mathbf{S}$ (1987) Acetylcholine receptor antibody in myasthenia gravis: predominance of $\operatorname{IgG}$ subclasses 1 and 3 . Clin Exp Immunol 67:82-88

39. Sahashi K, Engel AG, Lindstrom JM, Lambert EH (1978) Ultrastructural localization of immune complexes ( $\mathrm{IgG}$ and $\mathrm{C} 3$ ) at the end-plate in experimental autoimmune myasthenia gravis. J Neuropath Exp Neur 37:212-223

40. Statistics at square one (1978) TDV Swinscow Ed, British Medical Association, London

41. Tzartos SJ, Seybold ME, Lindstrom JM (1982) Specificities of antibodies to acetylcholine receptors in sera from myasthenia gravis patients measured by monoclonal antibodies. Proc Natl Acad Sci 79:188-192

42. Vernet-der-Garabedian B, Morel E, Bach J-F (1986) Heterogeneity of antibodies directed against the $\alpha$-bungarotoxin binding site on human acetylcholine receptor and severity of myasthenia gravis. J Neuroimmunol 12:65-74

43. Verschuuren JJGM, Spaans F, De Baets MH (1989) Single fiber electromyography in experimental autoimmune myasthenia gravis. Muscle Nerve, accepted for publication

44. Vincent A (1980) Immunology of acetylcholine receptors in relation to myasthenia gravis. Physiol Rev 60:756-823

45. Vincent A, Bilkhu M (1982) Anti-acetylcholine receptor antibody: use of polyethylene glycol as an aid to precipitation of antibody-receptor complexes in determination of light chain and subclass. J Immunol Meth 51:359-369

46. Yamamoto T, Lang B, Vincent A, Newsom-Davis J (1989) Plasma from anti-AChR Ab negative MG patients reduces $\mathrm{Na}+$ influx into TE671 cells. Proceedings of 2 nd european conference on myasthenia gravis p. 66 (abstract) 


\section{SINGLE FIBER}

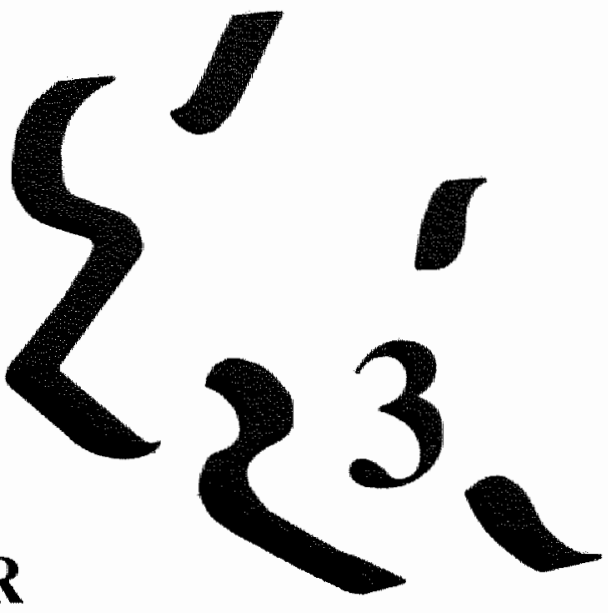

\section{ELECTROMYOGRAPHY IN}

\section{EXPERIMENTAL AUTOIMMUNE}

MYASTHENIA GRAVIS

Jan J.G.M. Verschuuren, Frank Spaans, and Marc H. De Baets 
$\therefore$ 


\section{Introduction}

Chronic experimental autoimmune myasthenia gravis (EAMG) models the pathophysiology of human myasthenia gravis (MG) $(4,10,20)$. Disease severity in chronic EAMG can be assessed on the basis of weight loss and other clinical symptoms, and by electrophysiological methods. Clinical abnormalities are seen relatively late in the course of the disease, and not all animals are equally affected $(10,11,20)$. Repetitive nerve stimulation, even after administration of a small dose of curare (2-6 $\mu \mathrm{g}$ ), does not produce a decremental muscle response in all rats with chronic EAMG (20). We therefore looked for a more sensitive method to detect the presence of disease at an early stage and to measure disease severity. Measurement of neuromuscular jitter by single fiber electromyography (SFEMG) is known to be a very sensitive test for the evaluation of neuromuscular transmission defects in man $(5,18,19)$. With this technique neuromuscular disturbances can be detected before impulse blocking occurs, i.e. before decrement is seen $(5,22)$.

Jitter measurements can be performed during slight voluntary muscle contraction, as well as during electrical stimulation of motor nerve fibers (24). The latter technique has been shown to be very useful in man $(24,25)$ and is of course the sole possibility in animals. The aim of this study was to test the sensitivity of SFEMG technique for the detection of abnormal neuromuscular function in the rat. Findings were compared with decrement studies, clinical symptoms, anti-acetylcholine receptor (AChR) titers, AChR content and AChR-antibody complexes in muscle.

\section{Materials and methods}

\section{Animal model of experimental autoimmune myasthenia gravis}

The inbred female Lewis rats which were used for the induction of experimental autoimmune myasthenia gravis (EAMG), the preparation of Torpedo californica acetylcholine receptor (AChR), clinical scoring and weight loss were all similar as described in chapter 2.

\section{Induction of chronic EAMG}

At the age of 11 weeks rats were injected with purified AChR from Torpedo californica in $0.1 \mathrm{ml}$ phosphate-buffered saline (PBS), emulsified in an equal volume of complete Freund adjuvant (CFA). Four rats were immunized with $20 \mu \mathrm{g}$ Torpedo AChR (group A), 4 rats were immunized with $40 \mu \mathrm{g}$ Torpedo AChR (group $B$ ), and only PBS-CFA was given to 4 other animals (group C). 


\section{Assay of anti-AChR antibody titers}

Serum was obtained before immunization and afterwards at each electrophysiological session. Anti-rat AChR serum antibody concentration was measured by immunoprecipitation using ${ }^{125}$ I- $\alpha$-bungarotoxin (BT)-AChR as antigen, as described in chapter 2. Anti-Torpedo $\mathrm{AChR}$ serum antibody titers were determined using affinity purified Torpedo $\mathrm{AChR}\left(1 * 10^{-9} \mathrm{M}\right)$ which was labeled with ${ }^{125} \mathrm{I}-\alpha-\mathrm{BT}$ AChR $\left(2 * 10^{-9} \mathrm{M}\right)$ for a minimum of $4 \mathrm{hr}$. ${ }^{125} \mathrm{I}-\alpha-\mathrm{BT}-\mathrm{AChR}$ was incubated in a volume of $0.2 \mathrm{ml}$ PBS, containing $0.5 \%$ TRITON X-100 (Sigma/ Brunschwig chemie bv, Amsterdam), and $0.02 \% \mathrm{NaN}_{3}$ (TRITON-X-100-PBS-NaN3) with $5 \mu$ l diluted serum (1/10-1/500) overnight at $4^{\circ} \mathrm{C}$. The resulting complexes were precipitated along with carrier immunoglabulin $(5 \mu \mathrm{l}$ normal rat serum) by addition of $100 \mu \mathrm{l}$ goat anti rat immunoglobulin ( $50 \%$ ammoniumsulfate precipitate). After $4 \mathrm{hr}$ incubation at $4^{\circ} \mathrm{C}$, the samples were centrifuged for $3 \mathrm{~min}$ (Eppendorf centriguge 5413 , Merck, Hamburg) and the resulting pellet was washed once with $1 \mathrm{ml} 0.5 \%$ Triton-X-100-PBS-NaN3. Radioactivity was counted in a gamma counter (Compugamma, Pharmacia LKB, Woerden). The value for ${ }^{125} \mathrm{I}-\alpha-\mathrm{BT}-\mathrm{AChR}$ pelleted in the presence of normal rat serum $(5 \mu \mathrm{l})$ was subtracted from the assay value. The antibody titer was expressed as moles of ${ }^{125} \mathrm{I}-\alpha$-BT binding sites per liter $(3 \mathrm{a}, 10)$

\section{Measurements of $A C h R$ and $A C h R$-antibody complexes in rat muscle}

The concentration of $\mathrm{AChR}$ and $\mathrm{AChR}$-antibody complexes in the rat carcasses was determined according to Lindstrom, (10) with minor modifications. Each rat carcass or a biopsy from the gluteus medius muscle was frozen, minced and homogenized. Subsequently a sample of $50 \mathrm{~g}$ of the homogenized carcass or the muscle biopsy was used for extraction of AChR, as described indetail in chapter 2 .

\section{Electromyographic studies}

The gluteus medius muscle was used for electromyographic studies. Rats were anaesthetized with ketamine (NIMATEK), $800 \mu \mathrm{l} / \mathrm{kg}$. The gluteal area was shaved, and rats were restrained on a cork dissecting board. Body temperature was monitored with a dermal thermistor probe and skin temperature was kept constant at $33-35^{\circ} \mathrm{C}$ by an infrared heating lamp (DISA, Copenhagen, Denmark). Decrement studies were performed first, followed by SFEMG recordings. Measurements were analysed automatically by a Viking EMG machine (Nicolet Biomedical Instruments, Madison, WI, USA). Recordings were made in groups A and B before immunization, and at 14,28 , and 42 days, and in group $B$ also at 53 and 60 days after immunization. In control group $\mathrm{C}$ recordings were made at 60 days after immunization.

Decrement studies: Monopolar Teflon coated steel needles, with a bared tip of 0.8 $\mathrm{mm}$, were used for recording and stimulation. The recording electrodes were placed subcutaneously, one over the belly and the other in the distal tendon region of the 
gluteal muscle. The compound muscle action potential (CMAP) was recorded in response to supramaximal stimuli applied through needle electrodes to the superior gluteal nerve, while changes in peak to peak amplitude and area of the negative peak were measured during repetitive stimulation at 3,5 , and $10 \mathrm{~Hz}$. Stimulus duration was $0.2 \mathrm{~ms}$. During each test 7 stimuli were given, and this was repeated once. The results of two test series were averaged and a positive decremental response was defined as a decrease of more than $10 \%$ of the fifth response compared to the first response $(14,15,20)$

Next faradization with 5 seconds of $50 \mathrm{~Hz}$ stimulation was performed. Decrement was registered after 30 seconds, and after 1,2, and 3 minutes, using $5 \mathrm{~Hz}$ stimulation.

Stimulated single fiber EMG: Intramuscular nerve stimulaton was performed with monopolar teflon coated steel needles with $0.8 \mathrm{~mm}$ bared tip. The stimulating cathode was placed in the gluteal muscle and the anode was inserted subcutaneously at a distance of about $2 \mathrm{~cm}$. The needles were introduced through the intact skin. A ring electrode around the tail served as ground electrode. Stimulus duration was 50 $\mu \mathrm{s}$. The stimulating cathode was adjusted until a motor nerve branch could be stimulated with a current of 2 to $3 \mathrm{~mA}$. Then the recording electrode was introduced in the contracting part of the muscle. Common single fiber electrodes were used for recording. Filters were set at $1 \mathrm{KHz}$ for the high pass and $20 \mathrm{KHz}$ for the low pass filter. The jitter of muscle fiber potentials was computed as the mean consecutive difference (MCD) from a series of 100 interval measurements between stimulus artefact and muscle fiber potential. Before measuring, a stimulus strength was chosen which was at least $20 \%$ above the threshold value for the relevant fiber. In each rat 10 to 20 neuromuscular synapses were studied, each with stimulus frequencies of 3,5 , and $10 \mathrm{~Hz}$. In order to find new fibers, and to record them in isolation, slight adjustments of the recording electrode were performed. The stimulating electrode was moved several times to find another nerve twig. The examination started with a stimulus frequency of $3 \mathrm{~Hz}$. Thereafter the frequency was increased to 5 and $10 \mathrm{~Hz}$ respectively. In $90 \%$ of the measurements the same fiber could be recorded at 3,5 , and $10 \mathrm{~Hz}$. In stimulated SFEMG there is a possibility of direct muscle stimulation. At $10 \mathrm{~Hz}$ stimulation in man MCD values below $5 \mu \mathrm{s}$ are considered to be due to direct muscle fiber stimulation (24). In the rat jitter values of direct fiber stimulation are unknown, but it is conceivable that they are not essentially different from the values found in man. In pilot studies we found that, measuring from the same fiber, MCD values at $10 \mathrm{~Hz}$ could be up to $4 \mu \mathrm{s}$ lower than at $3 \mathrm{~Hz}$. As every SFEMG study started at $3 \mathrm{~Hz}$, we decided arbitrarily to accept only fibers with MCD values of more than $9 \mu \mathrm{s}$ at $3 \mathrm{~Hz}$ stimulation. Using this protocol, no MCD value below $5 \mu$ s was registered in the normal rat at any of the three frequencies. Recordings were stored on the hard disc of the EMG machine and reanalysed afterwards. 
For statistical analysis Wilcoxon's rank test was used.

\section{Results}

All eight animals immunized with Torpedo AChR in CFA developed circulating antibodies against Torpedo $\mathrm{AChR}$ (range 2.14-13.2 $\mu \mathrm{mol} / \mathrm{L}$ ) and rat $\mathrm{AChR}$ (range $0.7-38.7 \mathrm{nmol} / \mathrm{L}$ ). No significant differences were found between groups $A$ and $B$ (Fig 3.1). All rats were observed for signs of EAMG. Three rats demonstrated clinical signs, first appearing in week 5 after inoculation with $\mathrm{AChR}$, and weight loss was seen in two rats (Table 3.1).

\section{AChR measurements}

AChR measurements $\mathrm{AChR}$ content and AChR-antibody complexes were quantified in gluteus medius muscle biopsies and in the carcasses at the end of the experimental period. Gluteus medius muscles of groups A and B showed an AChR loss of, respectively, $47 \pm 11 \%$ and $58 \pm 7 \%$ (mean \pm SD) at six weeks after immunization. At 8.5 weeks after immunization the AChR loss in group B was 36 $\pm 7 \%$. Mean AChR loss in carcasses in group A was $64 \pm 8 \%$, that in group B $55 \pm$ $6 \%$ (Table 3.2). Two animals which showed clinical signs of EAMG and weight loss had not significantly more AChR loss (65\% and $62 \%)$ than the clinically unaffected animals. The amount of AChR loss in the gluteus medius muscles was proportional to the AChR loss in the corresponding carcasses $(r=0.925, p<0.001)$. The AChRantibody complexes in the carcasses of the AChR immunized rats varied between 4 and $79 \%$ and correlated well with the anti-rat $A C h R$ titer $(r=0.899, p<0.01) . A C h R-$ antibody complexes measured in the carcasses of the control group were maximally $0.7 \%$.

\section{Decrement studies}

The mean CMAP amplitude before immunization was $43 \pm 10 \mathrm{mV}$, range: 30 to 56 $\mathrm{mV}$. A decrement in the amplitude or area of the CMAP occurred in only 2 rats, coinciding with grade +++ clinical signs of EAMG (Table 3.1 and 3.3). 

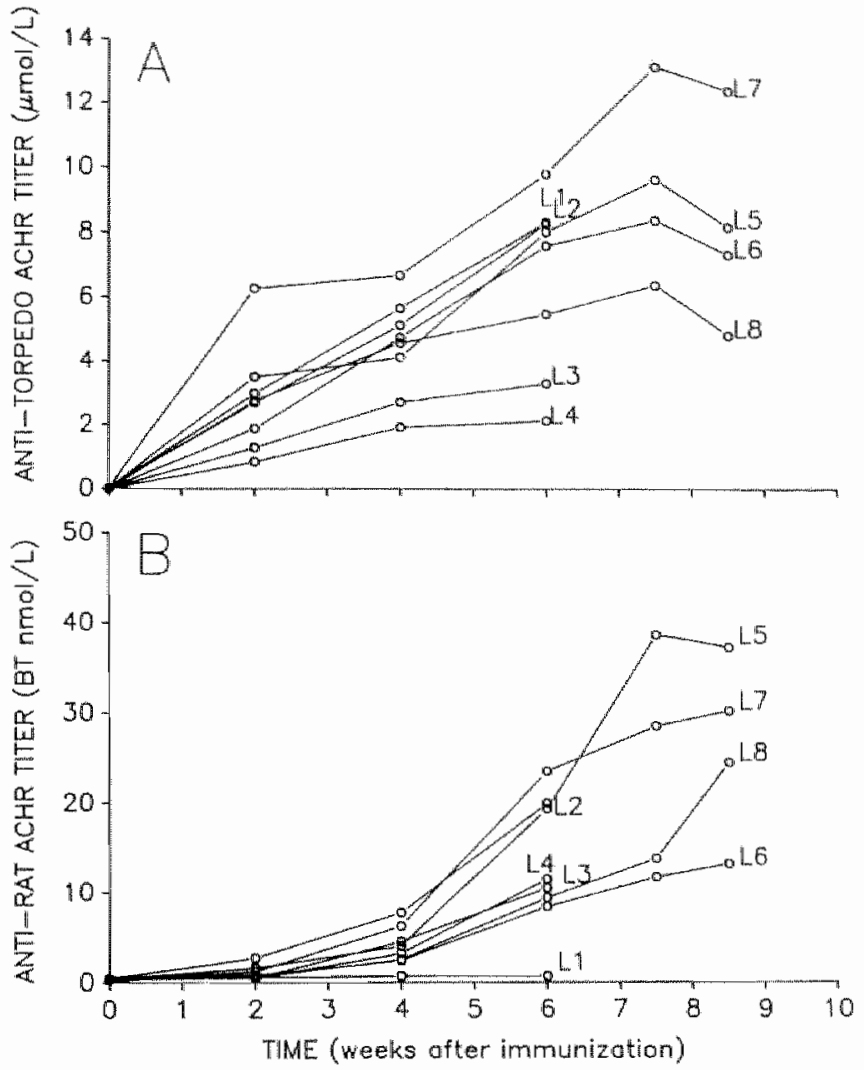

FIGURE 3.1 Kinetics of the immune response against Torpedo AChR. Rats were immunized with $20 \mu \mathrm{g}(L 1-L A)$ or $40 \mu \mathrm{g}$ Torpedo-AChR in CFA (L5-L8). Anti-Torpedo AChR (A) and anti-rat AChR antibody titers (B) were measured at given time intervals after immunization.

\section{SFEMG studies}

Fig 3.2 shows a typical example of a SFEMG recording. The mean MCD value of the gluteus medius muscle before immunization $(n=81)$ was $13.9 \pm 2.6 \mu \mathrm{sec}, 14.8 \pm$ $3.3 \mu \mathrm{sec}, 11.5 \pm 4.0 \mu \mathrm{sec}$ (mean $\pm \mathrm{SD}$ ) at stimulation frequencies of 3,5 , and $10 \mathrm{~Hz}$ respectively.

At the end of the experiment the mean MCD value was abnormal in 5 rats (Table 3.3). Five rats progressively came to show abnormal mean MCD values, and an additional two rats developed two or more single MCD values exceeding the upper limit of normal without abnormal mean MCD. The earliest abnormal mean MCD 


\begin{tabular}{|c|c|c|c|c|c|c|}
\hline rat & Illness & weight loss ${ }^{6}$ & $\begin{array}{l}\text { increased } \\
\text { mean } \mathrm{MCD}^{\mathrm{c}}\end{array}$ & 2 MCD>nMax & blocking & decrement $t^{f}$ \\
\hline $\mathrm{L1}$ & - & - & - & $\begin{array}{l}\text { wh } 6 \\
5,10 \mathrm{~Hz}\end{array}$ & - & - \\
\hline L2 & wh 5 & $\begin{array}{l}\text { wk } 6 \\
24 \%\end{array}$ & $\begin{array}{l}\text { wk 4 } \\
10 \mathrm{~Hz}\end{array}$ & $\begin{array}{l}\text { wk } 2 \\
10 \mathrm{~Hz}\end{array}$ & $\begin{array}{l}\text { wk } 2 \\
10 \mathrm{~Hz}\end{array}$ & wk 6 \\
\hline $\mathrm{L3}$ & wk 6 & - & $\begin{array}{l}\text { wk } 6 \\
5,10 \mathrm{~Hz}\end{array}$ & $\begin{array}{l}\text { wk } 6 \\
3,5,10 \mathrm{~Hz}\end{array}$ & $\begin{array}{l}\text { wk } 6 \\
5,10 \mathrm{~Hz}\end{array}$ & - \\
\hline LA & - & 一 & - & - & - & 一 \\
\hline L5 & wk 7.5 & $\begin{array}{l}\text { wk } 7.5 \\
20 \%\end{array}$ & $\begin{array}{l}w \mathrm{k} 7.5 \\
5 \mathrm{~Hz}\end{array}$ & $\begin{array}{l}w 6 \\
5 \mathrm{~Hz}\end{array}$ & $\begin{array}{l}\text { wk } 7.5 \\
3,5,10 \mathrm{~Hz}\end{array}$ & we 8.5 \\
\hline L6 & - & - & - & $\begin{array}{l}\text { wk } 7.5 \\
3,5,10 \mathrm{~Hz}\end{array}$ & $\begin{array}{l}w \mathrm{k} 7.5 \\
10 \mathrm{~Hz}\end{array}$ & - \\
\hline L7 & - & - & $\begin{array}{l}\text { wk } 8.5 \\
10 \mathrm{~Hz}\end{array}$ & $\begin{array}{l}\text { wk } 8.5 \\
3,10 \mathrm{~Hz}\end{array}$ & $\begin{array}{l}\text { wh } 8.5 \\
10 \mathrm{~Hz}\end{array}$ & - \\
\hline L8 & - & - & $\begin{array}{l}\text { wk } 7.5 \\
10 \mathrm{~Hz}\end{array}$ & $\begin{array}{l}\text { wk } 4 \\
5 \mathrm{~Hz}\end{array}$ & $\begin{array}{l}\text { wk } 7.5 \\
3,5,10 \mathrm{~Hz}\end{array}$ & - \\
\hline
\end{tabular}

TABLE 3.1 Earliest clinical and single fiber electromyography abnormalities in eight myasthenic rats. "First point of time, expressed as weeks, after immunization on which clinical illness (grade + ) was obserwed. ${ }^{b}$. First point of time after immunization on which weight loss was observed, percentage gives weight loss at end of experiment. ${ }^{c}$; Mean MCD values higher than the control mean MCD plus 2 standard deviations at the given frequencies. ": Two or more single MCD values above the highest MCD value (nMax) found in control rats. ${ }^{c}$ :One or more single fiber potentials with blocking. " First point of time, at which decrement was found.

was seen 4 weeks after immunization, and the first instance of two or more single MCD values exceeding the upper limit of normal was seen at 2 weeks after immunization (Table 3.1). The highest mean MCD value was seen at 8.5 weeks after 


\begin{tabular}{|c|c|c|c|c|c|c|}
\hline \multirow[t]{4}{*}{ Time } & \multirow{3}{*}{$\begin{array}{l}\text { Group } \\
\text { Loss }\end{array}$} & \multicolumn{2}{|c|}{ Gluteus medius muscle } & \multicolumn{3}{|l|}{ Carcass } \\
\hline & & {$[\mathrm{AChR}]$} & AChR & [AChR] & $\mathrm{AChR}$ & Complexes \\
\hline & & \multicolumn{5}{|l|}{ Loss } \\
\hline & & pmol/g & $\%$ & pmol/carcass $^{b}$ & $g_{0}^{\mathrm{a}}$ & $w^{\mathrm{c}}$ \\
\hline \multirow[t]{3}{*}{ Day 42} & A & $0.46 \pm 0.04$ & $47 \pm 5$ & $38.0 \pm 3.7$ & $64 \pm 4$ & $32 \pm 8$ \\
\hline & B & $0.37 \pm 0.03$ & $58 \pm 3$ & & & \\
\hline & $\mathrm{C}$ & $0.85 \pm 0.12$ & 0 & & & \\
\hline \multirow[t]{2}{*}{ Day 60} & $\mathrm{~B}$ & $0.55 \pm 0.02$ & $36 \pm 3$ & $47.2 \pm 2.7$ & $55 \pm 3$ & $60 \pm 7$ \\
\hline & $\mathrm{C}$ & $0.87 \pm 0.05$ & 0 & $105 \pm 8$ & 0 & $0.3 \pm 0.2$ \\
\hline
\end{tabular}

TABLE 3.2 Acetylcholine receptor ( $\mathrm{AChR}$ ) content of the gluteus medius muscles and carcasses as determined at $\mathbf{4 2}$ and $\mathbf{6 0}$ days after immunization. ". AChR loss, expressed" as percentage of the mean AChR content of the four control rats of the same age. " $A C h R$ content in the carcass. ${ }^{C}$ : AChR-antibody complexes, expressed as percentage the total amount of extracted AChR. All values are expressed as mean with standard errors.

immunization (Fig 3.3). In the control rats no abnormal jitter was found. Abnormal mean MCD values were found to increase with increasing stimulation frequencies. A stimulation frequency of $10 \mathrm{~Hz}$ was clearly most sensitive in detecting abnormal jitters (Fig 3.3).

Anti-rat AChR titer did not correlate with jitter (Fig 3.4). In 3 of the 8 animals with EAMG the rise in anti-rat AChR antibody titer parallelled increased jitter (Fig 3.5), although the same anti-rat AChR serum antibody titers could be found with and without SFEMG abnormalities (Fig 3.5b, and c). In one animal only very low titers were found. The other rats showed no correlation between MCD values and antibody titer.

After immunization increased jitters with blocking were seen in 6 of the 8 rats (Table 3.1 and 3.3). In recordings during which blocking was found, a maximum of $6 \%$ of the neuromuscular junctions showed blocking at $3 \mathrm{~Hz}, 25 \%$ at $5 \mathrm{~Hz}$, and $63 \%$ at $10 \mathrm{~Hz}$. For a given neuromuscular junction there was a significant correlation between the percentage of blockings and the MCD value $(r=0.736, p<0.001)$ (Fig 3.6). Potentials with abnormal MCD values at 3 and $5 \mathrm{~Hz}$ stimulation sometimes completely disappeared at $10 \mathrm{~Hz}$. After returning to 3 or $5 \mathrm{~Hz}$ the same potential reappeared. This procedure could be repeated several times, with identical results. 


\begin{tabular}{|c|c|c|c|c|c|c|c|}
\hline \multirow{3}{*}{$\frac{\text { rat }}{\text { LI }}$} & \multirow{3}{*}{$\frac{\text { wh }}{0}$} & \multicolumn{2}{|l|}{$3 \mathrm{~Hz}$} & \multicolumn{2}{|l|}{$5 \mathrm{~Hz}$} & \multicolumn{2}{|l|}{$10 \Psi z$} \\
\hline & & \multirow{2}{*}{$\frac{\text { mean MCD }}{13.5}$} & \multirow{2}{*}{$\frac{\mathrm{SD}}{1.6}$} & \multirow{2}{*}{$\begin{array}{l}\text { mean MCD } \\
13.9\end{array}$} & \multirow{2}{*}{$\frac{\mathrm{SD}}{2.8}$} & \multicolumn{2}{|c|}{ mean $M C D S D$} \\
\hline & & & & & & 12.6 & 5.6 \\
\hline & 2 & 13.3 & 1.7 & 12.5 & 1.9 & 11.6 & 6.3 \\
\hline & 4 & 14.9 & 2.8 & 15.7 & 4.4 & 9.8 & 6.6 \\
\hline & 6 & 14.0 & 3.7 & $17.4^{\circ}$ & 12.6 & $15.2^{\mathrm{c}}$ & 17.7 \\
\hline \multirow[t]{4}{*}{112} & 0 & 15.4 & 3.2 & 16 & 2.9 & 12.7 & 2.8 \\
\hline & 2 & 12.6 & 1.5 & 12.3 & 2.8 & $12.9^{\mathrm{bc}}$ & 8.4 \\
\hline & 4 & $16.6^{\mathrm{c}}$ & 5.6 & $20.7^{\circ}$ & 13.9 & $21.5^{a b c}$ & 21.2 \\
\hline & 6 & 17.0 & 5.1 & $23.2^{3 \mathrm{c}}$ & 15.0 & $38.6^{\mathrm{sbc}}$ & 37.7 \\
\hline \multirow[t]{4}{*}{ L3 } & 0 & 13.9 & 28 & 14.2 & 2.2 & 12.8 & 3.4 \\
\hline & 2 & 12.8 & 2.4 & 13.3 & 5.6 & 9.6 & 4.8 \\
\hline & 4 & 16.0 & 3.2 & 16.7 & 3.1 & 12.2 & 3.8 \\
\hline & 6 & $17.6^{\circ}$ & 8.9 & $21.4^{a b c}$ & 13.9 & $22.3^{a b c}$ & 16.9 \\
\hline \multirow[t]{4}{*}{ L4 } & 0 & 13.1 & 2,4 & 13.7 & 2,8 & 9.4 & 4.0 \\
\hline & 2 & 12.9 & 1.9 & 13.6 & 3.1 & 9.6 & 3.3 \\
\hline & 4 & 14.2 & 3.5 & 16.1 & 4.4 & 11.6 & 4.5 \\
\hline & 6 & 11.9 & 2.2 & 12.3 & 2.6 & 8.3 & 2.5 \\
\hline \multirow[t]{6}{*}{$\mathbb{L} 5$} & 0 & 13.3 & 1.7 & 13.9 & 3.2 & 11.4 & 4.9 \\
\hline & 2 & 13,4 & 2.1 & 13.5 & 2.1 & 8.6 & 1.8 \\
\hline & 4 & 13.2 & 4.2 & 13.1 & 4.0 & 13.7 & 4.8 \\
\hline & 6 & 13.8 & 2.9 & $16.8^{\circ}$ & 6.7 & 12.1 & 6.4 \\
\hline & 7.5 & $17.5^{b c}$ & 5.0 & $22.8^{\mathrm{abc}}$ & 18.0 & $14.1^{b c}$ & 8.6 \\
\hline & 8.5 & $21.8^{a b c}$ & 15.1 & $24.3^{\mathrm{abc}}$ & 12.0 & $41.5^{a b c}$ & 30.4 \\
\hline \multirow[t]{6}{*}{ L6 } & 0 & 13.6 & 2.8 & 15.4 & 3.6 & 11.1 & 4.0 \\
\hline & 2 & 11.4 & 1.6 & 13.0 & 2.0 & 9.7 & 1.8 \\
\hline & 4 & 14.5 & 2.5 & 14.0 & 3.3 & 9.9 & 5.2 \\
\hline & 6 & 13.6 & 29 & 15.8 & 5.1 & 11.4 & 6.1 \\
\hline & 7.5 & $18.8^{\circ}$ & 8.9 & $18.9^{\mathrm{c}}$ & 6.4 & $18.1^{\text {be }}$ & 7.6 \\
\hline & 8.5 & 13.1 & 2.2 & $14.7^{b}$ & 4.2 & $12.4^{\mathrm{b}}$ & 8.5 \\
\hline \multirow[t]{6}{*}{ L.7 } & 0 & 13.2 & 2.5 & 14.1 & 3.6 & 10.5 & 4.2 \\
\hline & 2 & 12.0 & 2.3 & 12.5 & 2.1 & 11.7 & 5.8 \\
\hline & 4 & 15.0 & 4.9 & 15.1 & 5.4 & 11.4 & 8.2 \\
\hline & 6 & 16.8 & 14.2 & 13.5 & 2.4 & 11.9 & 4.6 \\
\hline & 7.5 & 12.4 & 1.6 & 12.1 & 2.7 & 7.0 & 3.5 \\
\hline & 8.5 & $13.8^{\circ}$ & 4.5 & 16.2 & 10.1 & $20.0^{\mathrm{abc}}$ & 24.6 \\
\hline \multirow[t]{6}{*}{ L8 8} & 0 & 14.8 & 3.2 & 17.1 & 4.1 & 12.3 & 4.0 \\
\hline & 2 & 13.1 & 3.2 & 12.7 & 3.3 & 8.8 & 3.2 \\
\hline & 4 & 14.8 & 3.9 & $15.9^{\circ}$ & 5.0 & 8.9 & 2.7 \\
\hline & 6 & $15.4^{\mathrm{c}}$ & 5.1 & $16.5^{\circ}$ & 9.7 & 10.7 & 4.7 \\
\hline & 7.5 & $16.3^{b c}$ & 6.2 & $19.0^{\mathrm{bcc}}$ & 9.8 & $20.4^{\mathrm{abc}}$ & 13.4 \\
\hline & 8.5 & $19.7^{\mathrm{abc}}$ & 12.0 & $23.7^{\mathrm{abc}}$ & 26.8 & $23.8^{a b c}$ & 23.0 \\
\hline
\end{tabular}




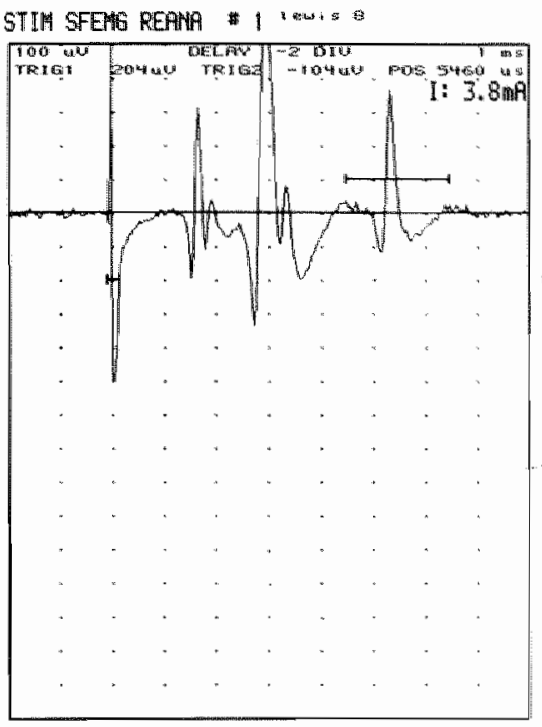

$12: 49552$

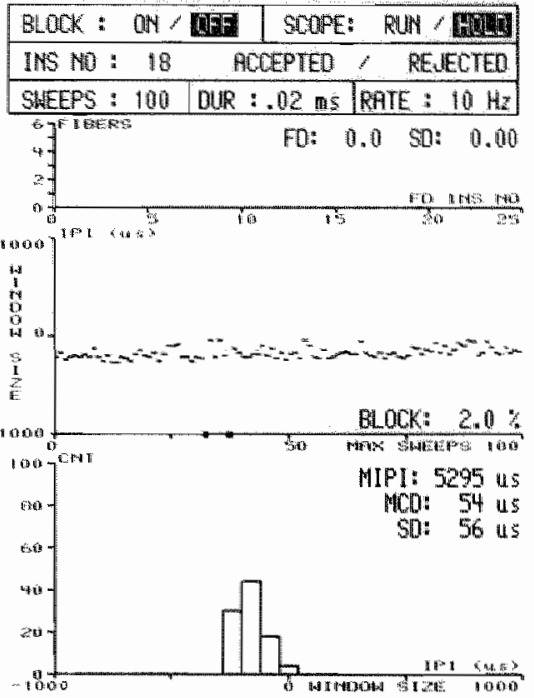

FIGURE 3.2 Example of a stimulated single fiber electromyography recording. On the lefi side of the figure the stimulus artefact (first deflection) and the recorded potentials are visualised, on the right analysis of jitter is shown. On the lower deflection of the stimulus artefact the first trigger may be noticed. Several single muscle fiber potentials are recorded at the same time. Measurements performed on the last potential, as indicated by the second trigger bar, are shown in the middle and lower section on the right (IPI: interpotential interval between stimulus artefact and crossing point of the up-going deflection of the studied wuscle potential). The measured MCD is clearly increased (highest normal value $21 \mu \mathrm{s}$ ) and 2 blockings are noticed.

The relationship between $A C h R$ loss or $A C h R$ complexes and the severity of neuromuscular dysfunction was investigated. The AChR content of the gluteus medius muscles and carcasses was not proportional to the mean MCD value at 10 $\mathrm{Hz}$ stimulation (Fig 3.7). Similar results were found for other frequencies (not shown). The AChR-antibody complexes correlated well with anti-rat AChR antibody titer, as mentioned above, but not with SFEMG results.

TABLE 3.3 Results of stimulated SFEMG studies. Figures express mean MCD values with standards deviation at several weeks after immunization. ": Mean MCD above control plus two standard deviations. ${ }^{b}$ : One or more fibers with biocking. ${ }^{c}$ : Two or more jitters above the highest single MCD value found in controls. 


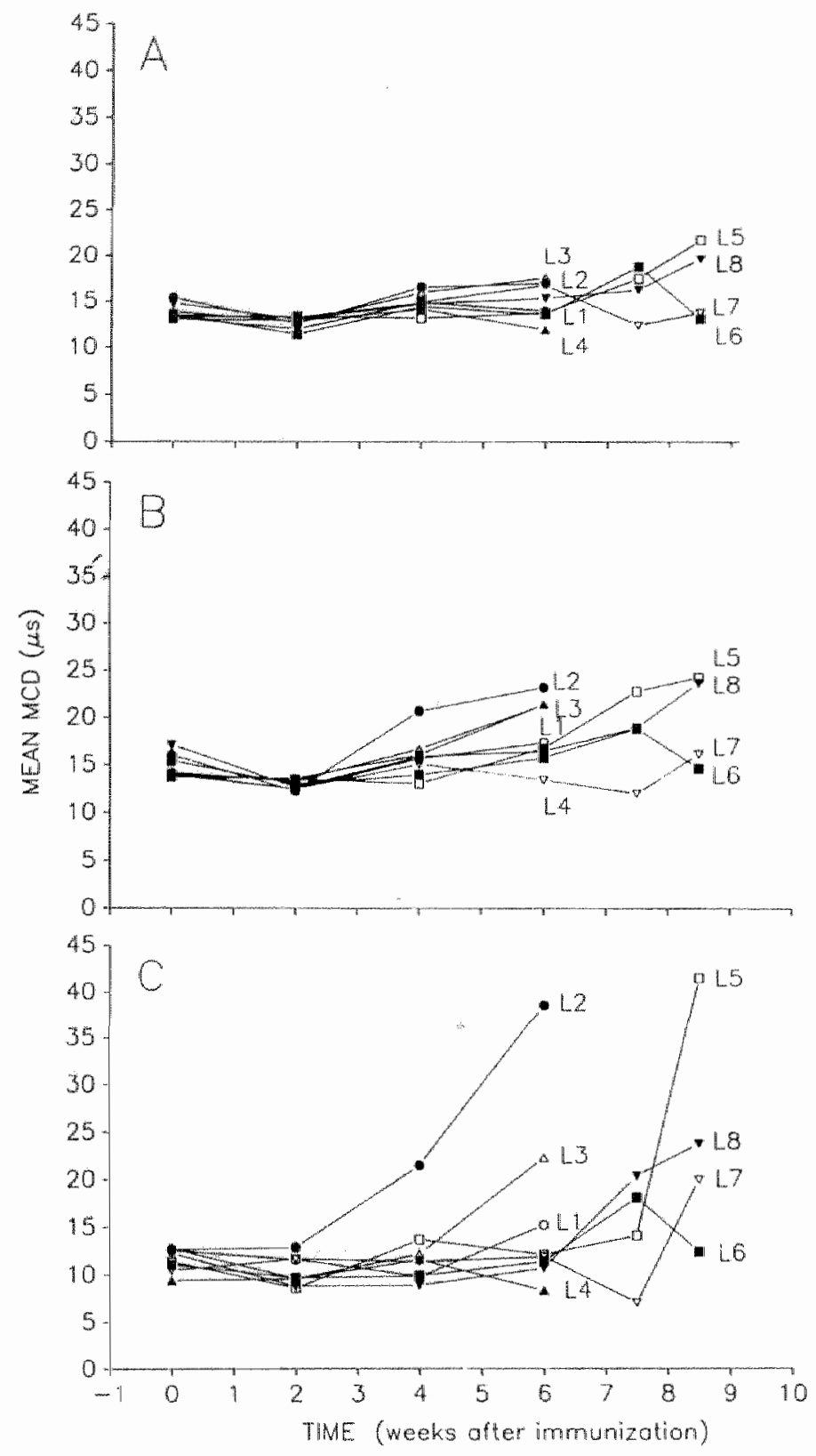

FIGURE 3.3 Results of single fiber electromyography.

Mean MCD measured by stimulated single fiber electromyography at $3 \mathrm{~Hz}(\mathbf{A}), 5 \mathrm{~Hz}$ (B), and $10 \mathrm{~Hz}(\mathrm{C})$ stimulation at given time intervals after immunization in eight rats (LI to L8). 




FIGURE 3.4 Comparison between jitter, expressed as mean MCD measured at $10 \mathrm{~Hz}$ stimulation, and anti-rat $\mathrm{AChR}$ antibody titer. Recordings made in all eight immunized animals at different time intervals after immunization are represented.

\section{Discussion}

We found stimulated SFEMG to be a sensitive diagnostic test in chronic EAMG. Abnormal jitter developed in 7 out of 8 immunized rats. Increased jitter always preceded decrement of the CMAP and the development of clinical signs of chronic EAMG. In agreement with these results a single study showed abnormal jitter values in 3 myasthenic rabbits prior to the appearance of a decremental response (6). In female Lewis rats and mice it was found that decrement without provocative tests occurred only in clinically myasthenic animals $(1,8)$. In man SFEMG has proved to be the most sensitive electromyographic technique for demonstrating abnormal transmission in MG $(5,23)$.

Normal jitter values in rats appeared to be in the same range as in man. At $10 \mathrm{~Hz}$ stimulation we found a mean MCD of $11.5 \pm 4.0 \mu \mathrm{s}$ (gluteus medius muscle), whereas Trontelj et al. found $17.1 \pm 8.2 \mu \mathrm{s}$ in the human extensor digitorum 


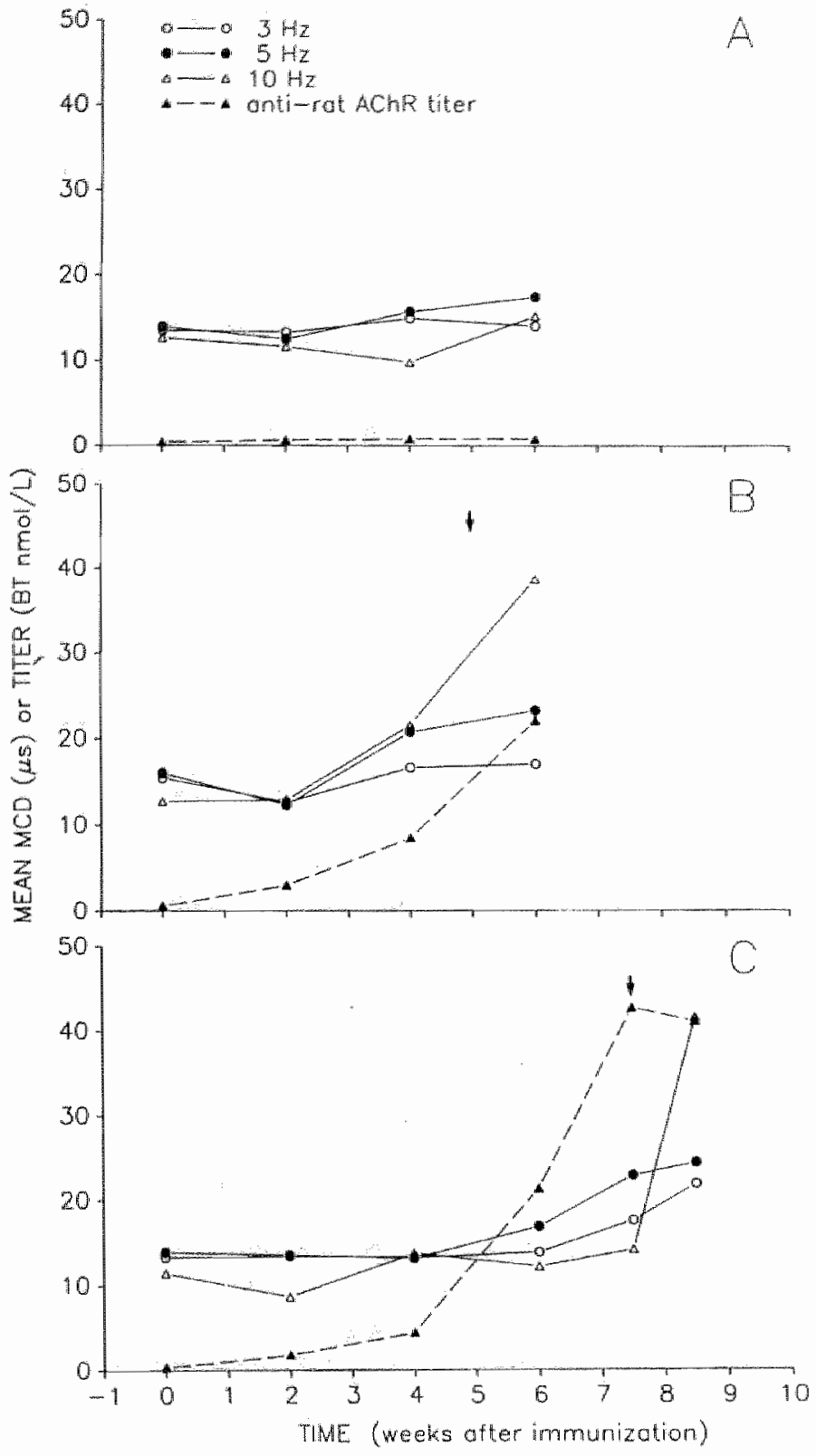

FIGURE 3.5 Comparison of the kineties of jitter (mean MCD value) versus anti-rat AChR antibody titers (bungarotoxin (BT) binding places per liter) in three rats with EAMG . (A) rat $L I$ has a low titer and no SFEMG abnormalities (B) In rat L2 increased jitter at $10 \mathrm{~Hz}$ stimulation parallels the anti-rat AChR antibody titer (C) In rat $L 5$ the rise in serum anti-rat AChR antibody titer preceeds increased jitter at $10 \mathrm{~Hz}$. First signs of clinical abnormalities are indicated by an arrow. 


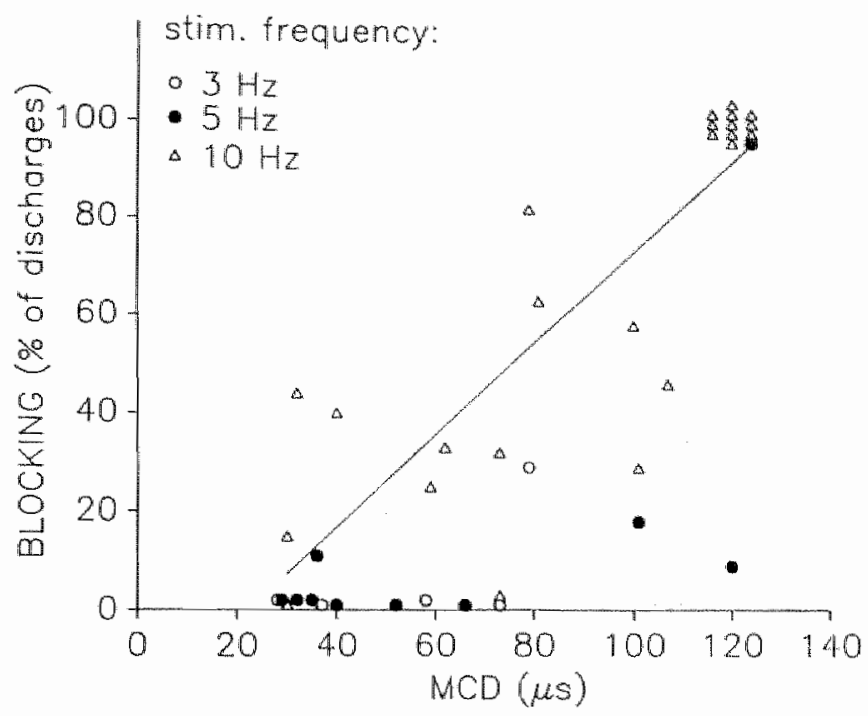

FIGURE 3.6 Correlation between the percentage of blockings and the MCD value at a given neuromuscular junction. Data of all eight immunized rats are represented. Each $M C D$ has been derived from 100 discharges. Blocking is expressed as the percentage of blocked discharges. Values in upper right cormer all represent $100 \%$ blocking. The solid line represents the regression analysis of the $M C D$ value recorded at $10 \mathrm{~Hz}$ stimulation $(r=0.74$, $p<0.001$ ).

communis muscle. From voluntary SFEMG studies it is known that normal values are somewhat lower in a number of proximal muscles. In our study we used 3 stimulation frequencies. It was found that $10 \mathrm{~Hz}$ stimulation was most sensitive in detecting early neurophysiological signs of EAMG. In myasthenic animals the mean MCD values increased proportional to the frequency used. Similarly, a larger jitter has been demonstrated in $\mathrm{MG}$, when the motor unit is firing more rapidly (21). It has been suggested that this is due to a discrepancy between the emptying and filling of the readily releasable fraction of acetylcholine (21). Hence, it is not suprising that blocking of the neuromuscular transmission was more readily detected at higher stimulation frequencies. Total blocking of individual neuromuscular junctions at $10 \mathrm{~Hz}$ would have been missed, if no registration at lower frequencies had been made. Therefore stimulated SFEMG in the rat is most sensitive at $10 \mathrm{~Hz}$, but it should be performed in combination with a lower frequency, for example 3 Hz. 


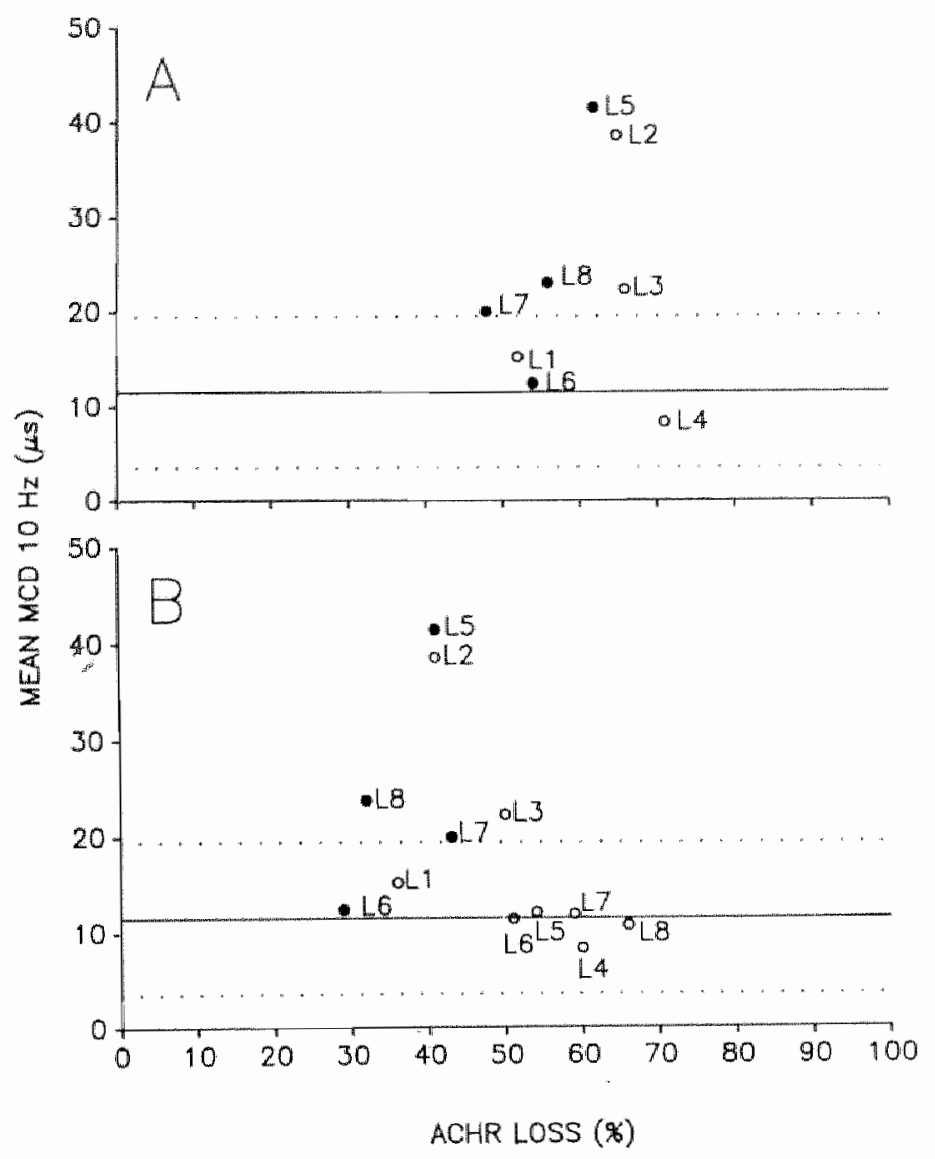

FIGURE 3.7 Comparison between AChR loss and the mean MCD values, recorded at 10 Hz stimulation. (A) AChR loss in the total carcass. (B) AChR loss in the gluteus medius muscles. Open circles represent muscle tissue obtained at 6 weeks after immunization, solid circles represent muscle tissue obtained at 8 weeks after immunization. Solid line represents normal mean $M C D$ at $10 \mathrm{~Hz}$ stimulation, and dashed lines indicate mean \pm 2 standard deviations.

It was investigated wether any relation could be found between these SFEMG abnormalities and titer or AChR loss. In our experiment the mean MCD values at all frequencies tested were not proportional to serum anti-Torpedo AChR and anti-rat AChR titers. This is in agreement with studies which show that anti-AChR antibody titers correlate poorly with clinical parameters $(1,7,17)$. Next we studied AChR loss in carcasses and gluteus medius muscles. If the amount of AChR in muscle were the 
major factor determining the quality of neuromuscular transmission, then a direct relation should exist between AChR loss and SFEMG abnormalities. We could not find such a relationship in the carcasses, nor in the gluteus medius muscles. Moreover, the AChR loss measured in the gluteus medius muscles decreased between 6 and 8 weeks after immunization, while in the same period SFEMG abnormalities were still increasing. Therefore we conclude that in addition to AChR loss other factors must determine SFEMG abnormalities. These results are concordant with previous reports in mice and man, were it was suggested that weakness in MG is in general related to the reduction of AChR's, though in individual cases the number of junctional AChR's does not predict strength $(3,16)$. Recently it was concluded from a study in 9 inbred rat strains, that no correlation could be found between AChR loss and clinical condition, but that the amount of antibodies bound to AChR in vivo determined the difference in clinical condition (2). We also found large amounts of AChR complexed with antibody in our electrophysiologically abnormal rats. However, there is a direct relationship of the serum anti-AChR antibody titer with the AChR-antibody complexes in muscle, determined by Triton extraction, but not with the severity of muscle weakness (13). In addition we found that washing muscle homogenates of myasthenic rat carcasses before Triton extraction reduces the AChR complexed with antibody to about $20 \%$ of the total amount of extractable AChR (Verschuuren, Graus, van Breda Vriesman, De Baets, unpublished results). This suggests binding of antibody during the extraction period, and thus it is unclear which percentage of the AChR-antibody complexes are formed in vivo. It is concluded that antibody bound to muscle may not be the only factor responsible for impaired neuromuscular transmission. Possible other factors which may contribute to abnormal jitter are variation in structural characteristics of the postsynaptical area $(4,8)$, distribution of acetylcholine in the enlarged synaptic clefts (8), distribution of AChR at the endplate (13), or binding of blocking antibody to AChR (26).

\section{Acknowledgments}

We wish to thank Liesbeth Geeraets for skilful assistance during EMG recordings, Yvo Graus for excellent laboratory assistance, Francien Teng for secretarial expertise, and the Beatrix foundation and the Nederlandse organisatie voor Wetenschappelijk Onderzoek (NWO) for their financial support. 


\section{References}

1. Berman PW, Patrick J (1980) Experimental myasthenia gravis. A murine system.J Exp Med 151:203-223

2. Biesecker $\mathbf{G}$, Koffler D (1988) Resistance to experimental autoimmune myasthenia gravis in genetically inbred rats. Association with decreased amounts of in situ acetylcholine receptor-antibody complexes. I Immunol 140:3406-3410

3. Chistadoss P, Lindstrom J, Munro S, Talal N (1985) Muscle acetylcholine receptor loss in murine experimental autoimmune myasthenia gravis: correlated with cellular, humoral and clinical responses. J Neuroimmunol 8:29-41

3a. De Baets MH (1984) Autoimmunity to cell surface receptors. Immumopathology of acetylcholine receptors in experimental autoimmune myasthenia gravis in the rat. Thesis, BV Leiter-Nypels, Maastricht p. 156-157

4. Engel AG, Tsujihata M, Lindstrom JM, Lennon VA (1976) The motor end plate in myasthenia gravis and in experimental autoimmune myasthenia gravis. A quantative ultrastructural-study. Ann N Y Acad Sici 274:60-79

5. Gilchrist JM, Sanders DB (1987) Double-step repetitive stimulation in myasthenia gravis. Muscle Nerwe 10:233-237

6. Heilbronn E, Mattson C, Thornell L-E, Sjöström M, Stålberg E, Hilton-Brown P, Elmqvist D (1976) Experimental myasthenia in rabbits: biochemical, immunological, electrophysiological, and morphological aspects. Ann N Y Acad Sici 274:337-353

7. Konishi T, Nishitani H, Matsubara F, Ohta M (1981) Myasthenia gravis: Relation between jitter in single-fiber EMG and antibody to acetylcholine receptor. Neurology 31:386-392

8. Lambert HE, Lindstrom JM, Lennon VA (1976) End-plate potentials in experimental autoimmune myasthenia gravis in rats. Ann N Y Acad Sci 274:300-318

9. Lennon VA, Lindstrom JM, Seybold ME (1975) Experimental autoimmune myasthenia gravis: a model of myasthenia gravis in rats and guinea pigs. J Exp Med 141:1365-1375

10. Lindstrom JM, Einarson BL, Lennon VA, Seybold ME (1976) Pathological mechanisms in experimental autoimmune myasthenia gravis. I. Immunogennicity of syngeneic muscle acetylcholine receptor and quantative extraction of receptor and antibody-receptor complexes from muscles of rat with experimental autoimmune myasthenia gravis. J Exp Med 144:726-738

11. Lindstrom J, Einarson B (1979) Antigenic modulation and receptor loss in experimental autoimmune myasthenia gravis. Muscle Nerve 2:173-179

12. Lindstrom J, Anholt R, Einarson B, Engel A, Osame M, Montal M (1980) Purification of acetylcholine receptors, reconstitution into lipid vesicles, and study of agonist-induced cation channel regulation. J Biol Chem 255:8340-8350

13. Mossman S, Vincent A, Newsom-Davis J (1988) Passive transfer of myasthenia gravis by immunoglobulins: lack of comelation between $\mathrm{AChR}$ with antibody bound, acetylcholine receptor loss and transmission defect. J Neurol Sci 84:15-28 
14. Oh SJ, Eslami N, Hishihira T, Sarala PK, Kuba T, Elmore RS, Nam Sunwoo I, II Ro Y (1982) Electrophysiological and clinical correlation in myasthenia gravis. Amn Newrol 12:348-354

15. Pachmer AR, Kantor FS (1982) Nerve stimulation test in murine experimental autoimmune myasthenia gravis. Ann Neurol 11:48-52

16. Pestronk A, Drachman MB, Self S (1985) Measurement of junctional acetylcholine receptors in myasthenia gravis: clinical correlates. Muscle Nerve 8:245-251

17. Roses AD, Olanow CW, McAdams MW, Lane RJM (1981) No dinect correlation between serum anti-acetylcholine receptor antibody levels and clinical state of individual patients with myasthenia gravis. Neurology 31:220-224

18. Sanders DB, Howard JF, Johns TR (1979) Single-fiber electromyography in myasthenia gravis. Neurology 29:68-76

19. Sanders DB, Howard JF (1986) AAEE Minimonograph \#25: Single-fiber electromyography in myasthenia gravis. Muscle Nerve 9:809-819

20. Seybold ME, Lambert EH, Lennon VA, Lindstrom JM (1976) Experimental autoimmune myasthenia: clinical, neurophysiologic, and pharmacologic aspects. Ann $N$ Acad Sici 274:275-282

21. Stålberg E, Ekstedt J, Broman A (1974) Neuromuscular transmission in myasthenia gravis studied with single fiber electromyography. J Neurol Neurosurg Psychiat 37:540547

22. Stålberg E, Schiller HH, Schwartz MS (1975) Safety factor in single human motor end-plates studied in vivo with single fiber electromyography. I Neurol Neurosurg Psychiat 38:799-804

23. Stålberg E (1980) Clinical electrophysiology in myasthenia gravis. J Neurol Neurosurg Psychiat 43:622-633

24. Trontelj J, Mihelin M. Fernandex JM, Stålberg E (1986) Axonal stimulation for end-plate jitter studies. J Neurol Neurosurg Psychiat 49:677-685

25. Trontelj JV, Khuraibet A, Mihelin M (1988) The jitter in stimulated orbicularis oculi muscle: technique and normal values. I Neurol Neurosurg Psychiat 51:814-819

26. Vernet-der-Garabedian B, Morel E, Bach J-F (1986) Heterogeneity of antibodies directed against the $\alpha$-bungarotoxin binding site on human acetylcholine receptor and severity of myasthenia gravis. INeuroimmunol 12:65-74 


\section{IDIOTYPES IN MYASTHENIA GRAVIS}
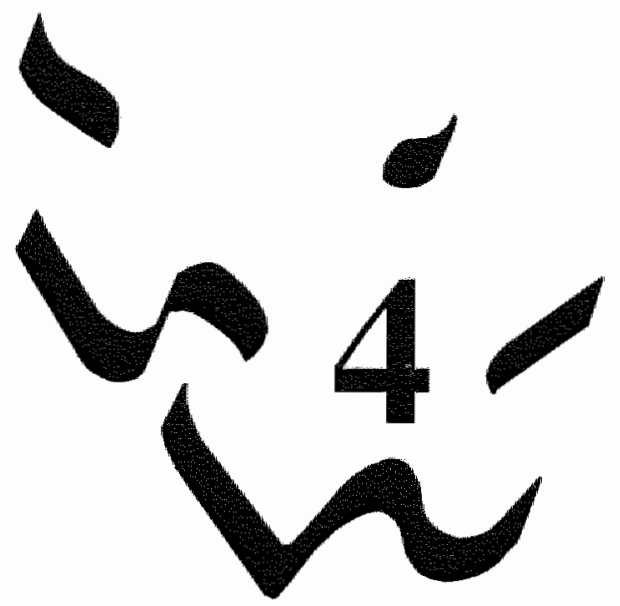
$\%$

.... 


\section{Idiotypes}

\section{History}

In 1890 von Behring and Kitasato gave the first description of serum antibodies (129). They studied animals immunized with diphtheria and tetanus toxins, and showed that their blood contained a factor capable of neutralizing or destroying the toxin; the substance that acted against the toxin was first called 'anti-toxin', and next antibody. The material which elicited this substance was called antigen. Since only a few antibodies were known at this time, they were thought to be antitoxins directed against a limited number of antigens. Consequently few investigators were troubled by the idea how it would be possible for the immune system to recognize a wide variety of antigens. Ehrlich proposed that antibodies were naturally occurring products that functioned as specific receptors on the surface membrane of the cell. These antigen receptors would be selected for by the appropiate antigen, which in turn would stimulate receptor production with their subsequent appearance as circulating antibodies in the blood. In the first decades of the 20th century, however, it became clear that antibodies could also be formed against non-bacterial substances, such as plant proteins or artificial chemical structures; hence, the potential antibody repertoire should be enormous. In an attempt to find an explanation for this large sized immunologic repertoire the 'instruction theory' was formulated. This theory suggested that an antigen could guide the formation of specific antibody, by instructing in the production of a complementary, unique molecular configuration. Thus, it was thought that the antigen acted like a template on which specific antibodies might be formed.

The instruction theories, however, did not explain how antibody production can persist in the absence of the antigen or why a second exposure to the same antigen results in both an accelerated and enhanced antibody response. It is clear that the important role of continuing cellular function and cell replication in the antibody response had been neglected. In 1955 Jerne formulated the 'natural selection' theory, in which he, like Ehrlich had done, proposed that each of the antibody specificities would spontaneously be produced prior to interaction with the antigen. A few years later Burnet postulated the 'clonal selection' theory of antibody formation. According to Burnet's theory antibodies are natural products which appear on the cell surface as receptors, which selectively recognize antigen. These receptors are present during the life cycle of the cell and before any interaction with antigen has occurred; these receptors, the surface Ig on the B cell, dictate the specificity of its antibody. Within a few years this theory gained wide acceptance (reviewed in 129). 


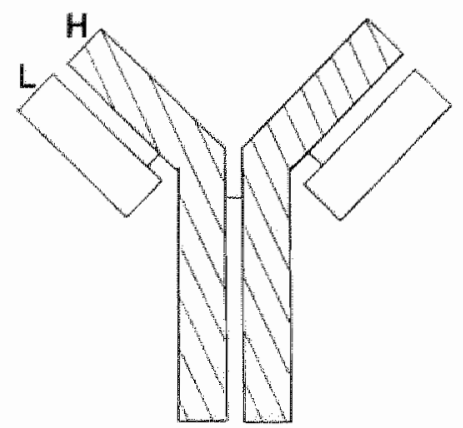

Heavy chain $(H)$

Light chain (L)

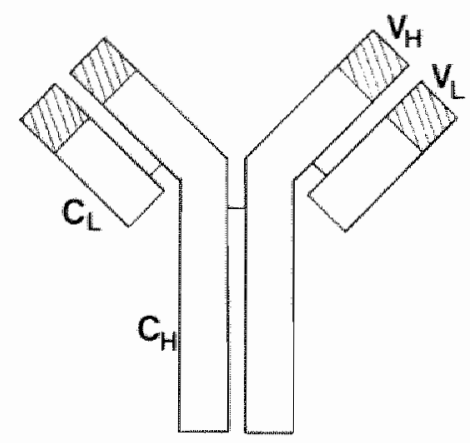

Constant region $\left(\mathrm{C}_{\mathrm{H}}, \mathrm{C}_{\mathrm{L}}\right)$

Variable region $\left(V_{H}, V_{L}\right)$

FIGURE 4.1 Structure of immunoglobulin molecule. An antibody is composed of 2 identical heavy $(\mathbf{H})$ and 2 light $(\mathbf{L})$ polypeptide chains, held together by interchain disulphide bonds (left hand figure). Within each chain a variable region ( $V$ ) and a relatively constant region (C) can be disthinghuised. The V regions contain the antigen binding site, the C regions lack the ability to bind antigen, but determine biological functions, such as compiement binding and placental transfer. On the light chain these regions are termed ' $\mathrm{V}_{\mathrm{L}}$ ' and ' $\mathrm{C}_{\mathrm{L}}$ ' respectively, and ' $\mathrm{C}_{\mathrm{H}}$ ' and ' $\mathrm{V}_{\mathrm{H}}$ ' specify variable and constant regions of the heavy chain. Since each pair of heavy chains and each pair of light chains are identical, two identical antigen binding sites are found on one antibady molecule.

\section{Structure of the immunoglobulin molecule}

The major function of antibodies is to bind specifically to antigen and to effect its inactivation or removal. These two functions are reflected in the structure of antibodies or immunoglobulins (Ig), which can be illustrated by looking at a monomeric form (Fig 4.1). Antibody molecules are composed of heavy (H) and light $(L)$ polypeptide chains, each containing a variable $(V)$ and constant $(C)$ region. Enzymes such as papain are able to split the molecule in three fragments: two Fab's (fragment antigen binding) responsible for binding of the antigen, and one $\mathrm{Fc}$ (fragment crystallizable) retaining the effector functions, e.g. complement binding and leucocyte cell receptor binding.

Within the variable region three hypervariable regions can be detected, which segments line directly the antigen combining site $(69,153)$. These segments are also called 'complementarity determining regions' (CDR). The antigen binding site is also termed 'paratope'. The intervening peptide sequences in the variable region are termed 'framework regions'. 




FIGURE 4.2 Generation of diversity for antigen recognition. Three clusters on 3 different chromosomes code for the heavy chains and kappa and lambda light chains, respectively. The genetic coding for the heavy chain is illustrated.

As shown at the top of the figure, there are a high number of $V$ gene segments ( 500 in the mouse), arranged in series of families. In addition, multiple $J$ genes ( 4 in the mouse) and in the case of the heavy chain, a serie of $D$ genes ( 15 in the mouse) code for the $V H$ region of the antibody molecule. Recombination events bring one $V$, one $D$, and one J segment together. These are aligned to one of the genes encoding the constant region ( $C_{H}$ genes). By variation of this $C_{H}$ gene the variable region can be expressed together with, for example, the $\mathrm{GM}$ or Ig $G_{1}$ isotype.

The rearranged DNA can be translated in $m R N A$, which encodes for one complete heavy chain, as indicated in the middle of the figure. Together with the light chains two heavy chains form a complete antibody molecule. Two dimensional representation of an antigen binding site is shown at the right. Six hypervariable regions, 3 from each V region, contribute to the antigen binding site.

Protein and gene sequences showed that the immunoglobulin molecule is an unique protein in that it is encoded by three unlinked families of genes. Two families encode for light chains termed lambda $(\lambda)$ and $k a p p a(\kappa)$, and one family for the heavy chain. These genes are localized on different chromosomes, in man the $\lambda, \kappa$, and heavy chain gene families are on respectively chromosome $22,2,14$ and in mice these chromosomes are 16,6 , and $12(34,36,44)$. 


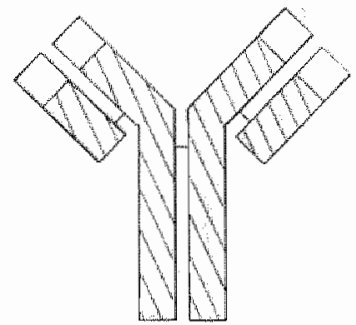

is atype

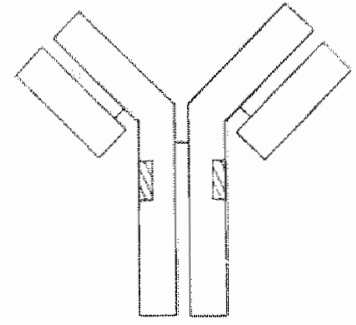

allotype

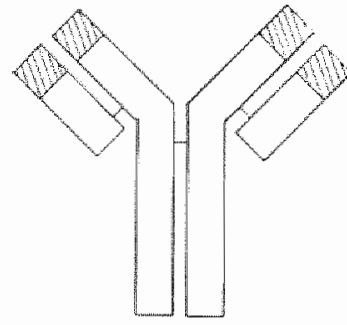

idiotype

FIGURE 4.3 Schematic presentation of structural equivalents of isotype, allotype and idiotype. The isotype is associated with the C region of the light and heavy chains. Examples are $I g M, I g G_{1}, I_{g A} A_{2}$ The allotype is most frequently located in the $C$ region of the light or heavy chain and depends on the existence of allelic forms of the same isotype, an example is the $G \mathrm{~m}$ marker on human $\mathrm{Ig} G$. The idiotype is structurally associated with the $V$ regions.

It has been estimated that mice can produce $10^{6}-10^{8}$ unique antibodies (128), and several theories were developed to account for this enormous diversity. On one hand the diversity of antibody combining site can be explained by rearrangement of the germline genes in the differentiation and maturation of immunocompetent cells (55) (Fig 4.2). On the other hand the somatic diversification theory postulated that the diversity was due to somatic mutation of (few) inherited genes (54). Mutation is characterized by a high frequency of nucleotide substitutions within a localized region surrounding the rearranged variable gene (94). It is thought that during a restricted time period hypermutation of the genes encoding the binding site of the antibody is permitted. Some mutations will lead to the production of antibodies with higher affinity for the antigen, and the B cells producing these antibodies will be selected.

Nowadays, both theories are known to be correct, whereby somatic mutation appears more involved in affinity maturation by 'fine-tuning' the antibody response (55). In the antibody response towards phosphorylcholine, it was described that mutations were generated mainly during the first week of the immune response and were selected for binding to antigen during the second week (94). According to the germline theory genes are rearranged, whereby the $V$ region of light chains $\left(V_{L}\right)$ is the result of the combination of $\mathrm{V}$ and $\mathrm{J}$ (Joining) gene segments, and the $\mathrm{V}$ region of the $H$ chain $\left(V_{H}\right)$ is the result of the combination of one $V, D$ (Diversity), and $J$ gene segment (54) (Fig 4.2). Further diversity arises from the combination of different $V_{H}$ and $V_{L}$ chains (19), the insertion of nucleotides at the $\mathrm{N}$ region 
between $D$ and $J$ segments (4), alternate reading frames of $D$ regions (100), and from the variable boundary recombinations (55). In this way it has been estimated that more than 24 million combinations are possible (55).

As discussed above, the hypervariable regions are directly involved in binding of the antigen. Therefore it is useful to consider the gene segments which contribute to the formation of these hypervariable regions. In both $\mathrm{L}$ and $\mathrm{H}$ chains the first and second hypervariable region is encoded by the $\mathrm{V}$ gene segment. In light chains, the third hypervariable region has contributions form both $V_{L}$ and $J_{L}$ gene segments. In the heavy chains, the $D$ segment encodes the major portion of the third hypervariable region, but also the J segment contributes to this region $(53,54)$.

Not only are antibodies capable of recognizing antigens, the antibody itself can serve as an antigen against which antibodies can be elicited. Several antigenic determinants (epitopes) on antibodies are able to elicit the production of antibodies against them, leading to the definition of at least three types of determinants, located in both heavy and light chains, that are used to classify antibodies: isotypes, allotypes and idiotypes.

\section{Isotype}

Immunoglobulins are classified into major groups termed classes, which can be further subdivided into subclasses. Together they form the isotype (Greek, 'isos': the same) of an antibody molecule. The structural counterpart of the isotypes generally are constant region determinants that distinguish the products of each of the light and heavy chain constant region genes from one another (69) (Fig 4.1, Fig 4.3). These genes are all expressed in every individual, so all isotypes are present in the sera of a normal individual in all members of a species. In man and rat there are five classes of heavy chains: $\operatorname{IgM}, \operatorname{IgD}, \operatorname{IgG}, \operatorname{IgE}, \operatorname{IgA}(6,100)$. In man $\operatorname{IgG}$ is further divided in subclasses $\operatorname{IgG}_{1}, \operatorname{IgG}_{2}, \operatorname{IgG}_{3}, \operatorname{IgG}_{4}$, and $\operatorname{IgA}$ in $\operatorname{IgA} \mathrm{A}_{1}$ and $\operatorname{Ig} \mathrm{A}_{2}$. In the rat the $\mathrm{IgG}$ molecules can be subdivided in $\mathrm{IgG}_{1}, \operatorname{IgG}_{2 \mathrm{a}}, \mathrm{IgG}_{2 \mathrm{~b}}$, IgG2c. The largest fraction of the immunoglobulins is made up by IgG (about 75\%), and the subclasses in man are numbered according to their serum level, i.e. $\operatorname{IgG}_{1}$ is most prevalent, $\mathrm{IgG}_{4}$ least.

In man, mouse and rat two classes of light chains are found: lambda $(\lambda)$ and kappa $(\kappa)$, and in man and mouse subclasses of the lambda type have been found. Within an immunoglobulin molecule the light chains are identical, so an antibody is either $\kappa$ or $\lambda$.

In man the $\kappa / \lambda$ ratio is about $70: 30$, whereas in mouse it is $95: 5(69)$. 


\section{Allotype}

Allotypes (Greek, 'allos': other) were first described by Oudin and Grubb in the late 1950s (47). Allotype refers to one or more determinants encoded for by one allele of a given immunoglobulin gene, In contrast to isotypes, which are present in all members of a species (all individuals have $\mathrm{IgG}_{1}$ in their serum), certain allotypes are only present in subgroups of the population (some people have $\mathrm{IgG}_{1}$ with the Glm(1) marker, while others produce $\operatorname{lgG}_{1}$ with the $\mathrm{Glm}$ (4) marker). Their structural counterpart is mainly found within the constant region, and is attributable to amino acid substitutions caused by mutations in the corresponding genes (47) (Fig 4.3). Gm allotypes (Gm: IgG marker) in man are found on IgG, and likewise allotypes on IgA are designated Am, and on $\kappa$ chain $\mathrm{Km}$ (115). In the rat allotypes have been described at the kappa light chains, the IgA heavy chain, and the IgG $2 b$ heavy chain $(4,57,124)$. Certain allotypes have found to be associated with autoimmune diseases. In rheumatoid arthritis IgM antibodies against IgG allotypes can be found. In mice the $\mathrm{Ig}-1^{b}$ allotype was shown to be associated with high susceptibility for experimental autoimmune myasthenia gravis (11).

\section{Idiotype}

Antigenic determinants expressed on variable region domains are called idiotypic determinants (Greek, 'idios': own). A single determinant is termed an idiotope, and the collection of idiotopes is called idiotype (68). Thus, in contrast to isotype and most allotypical markers, the structural counterpart of the idiotope is found on the variable region of the antibody (Fig 4.3). As idiotypes are associated with $V$ regions, swilches in the class of the antibody (e.g., from $\operatorname{IgM}$ to $\operatorname{lgG}$ ) does not result in changes of idiotype $(15 ; 53)$. An idiotope can be formed by the $\mathrm{V}_{\mathrm{H}}$ region $(10)$, $\mathrm{V}_{\mathrm{L}}$ region $(71,96)$, but in most cases it requires the combination of both $\mathrm{V}$ regions, in a conformation dependent fashion $(51,96,116,126)$. Further, a few cases of independent expression of an idiotope on both $\mathrm{V}$ regions have been reported $(116,160)$. Thus, it is evident that idiotopes are the phenotypic markers of a V-region, resulting from the expression of $\mathrm{V}$ germ line genes after recombinational events and somatic mutations (15).

Idiotypes were probably first detected by Lohss in 1953, the antigenic individuality of human myeloma proteins was demonstrated by Slater in 1955, and the concept was extended to induced antibodies by Oudin and Kunkel in 1963 (reviewed in 43), whereby Oudin was the first to use the term 'idiotypy'. Oudin immunized a rabbit with Salmonella bacteria, and then injected the antibodies produced by this animal into a second rabbit of the same allotype. The serum thus obtained reacted specifically with the anti-Salmonella antibodies of the first rabbit, but not with normal rabbit serum or anti-Salmonella sera of other rabbits. Oudin proposed the term 
'idiotypy" to designate the property of antibodies to possess these determinants, as recognized by the rabbit anti-rabbit Ig sera (105). Kunkel, who had made independently similar observations as Oudin, used the term 'individually specific antigenic determinants" ( 80 ), which however did not reach a general usage.

Potentially any exposed part of the variable region of heavy and light chain may be immunogenic. Regarding the structural diversity of the variable regions, the number of idiotypes potentially expressed by an individual is enormous, and the number of different idiotypes vastly exceeds the number of allotypes or isotypes. A relation between allotypes and idiotypes has been described, as it was found that idiotypes can be linked to the $\mathrm{C}_{\mathrm{H}}$ gene cluster, i.e. to $\mathrm{C}_{\mathrm{H}}$ allotype $(35,52)$. This is not unexpected, since it reflects the fact that $\mathrm{V}_{H}$ genes contribute to the idiotypic determinants, which are on the same chromosome as the CH genes (65). Also, a few cases of linkage of $\mathrm{V}_{\mathrm{H}}$ and isotype have been reported (35).

\section{Categorization of idiotopes}

Idiotopes can be categorized according to their localization on the immunoglobulin molecule, their quantative expression in the polyclonal antibody response, their fine specificity, or their immunoregulating capacities.

On the basis of localization idiotopes on the antibody molecule might divided into:

a) Paratope related idiotopes

These Id's are located in the antigen binding site and might be involved in antigen binding. Anti-idiotype antibodies against these Id's are able to block the binding of the antigen.

b) Framework related idiotopes

These Id's are located outside the antigen binding site, therefore an anti-idiotype antibody against them will not be able to block antigen binding.

Another distinction can be made, based on the percentage of antibodies in an immune response towards an antigen, which are positive for the particular idiotope.

a) Dominant idiotopes

An idiotope is termed dominant if a large percentage of the antibodies expresses this idiotope. An example can be found in the phosphorylcholine antigenic system, in which $80 \%$ of the serum antibodies carries the T15 idiotype (11).

b) Non-dominant idiotopes

Non-dominant idiotopes are only found on a minority of the antibodies in a polyclonal immune response. An example is the Id 62 on anti-thyroglobulin antibodies, as defined by Zanetti (32).

On the basis of prevalence idiotopes (Id) can be categorized as one of the following: 


\section{a) Private idiotopes}

These idiotypic determinants are thought to be restricted to a single B cell clone in a single individual. As the expression of private idiotopes is restricted, it is thought that they result from noninheritable somatic mutational or recombinational events, which probably can be reproduced in other individuals only by chance, and therefore will have a low prevalence. Private idiotopes are also referred to as minor or individual.

b) Crossreactive idiotopes

The most limited definition of crossreactive idiotopes (CRI's) is that they are shared among antibodies of several individuals from the same strain against the same antigen (143). However, CRI's can be found within one strain or can be shared by several strains $(8,52)$, or even species (15), and in addition sharing of idiotopes among antibodies of different specificity has been reported $(70,78,106)$. Therefore, a more global definition is that CRI's are idiotopes shared by several individuals.

CRI's can be located in the paratope or associated with framework determinants of the V region. Some investigators refer to framework related CRI's, present on antibodies of different specificity, as $V_{H}$ gene markers $(18,103)$, and do not consider them to be idiotopes (103). In fact, antibodies against these $\mathrm{V}_{H}$ gene markers were suggested to define a $V_{H}$ gene family subgroup, a kind of allotypic subclass within this gene familly (103). However, when Id's are defined as antigenic determinants of the total variable region, and not only those Id's associated with the paratope, this distinction is not made (128).

CRI's are also referred to as major, shared, cross-specific or public.

On the basis of functional properties idiotopes can be divided in regulatory and non-regulatory idiotopes.

The term regulatory idiotope was proposed by Paul and Bona $(14,107)$. They defined a special class of idiotopes which are interconnected in an idiotype network, and have the potential to fulfil a regulatory role in an immune response (107). Their expression is regulated by idiotype-specific $T$ cells $(14,17)$. This theory was developed as an extention of the network theory of Jerne (see below). It was previously thought for regulatory idiotopes to be widely represented in the immune system prior to contact with a given antigen (107). However, after immunization regulatory idiotopes were also found to be expressed on a minority of the antibodies elicited by antigen $(156,159)$. In addition, antibodies expressing regulatory idiotopes are not found in all immune responses (107).

\section{Anti-idiotypes}

Anti-idiotype antibodies are antibodies binding to idiotypes.

Anti-idiotype antibodies (anti-Id) will themselves carry idiotopes which, in turn, can be recognized by other anti-idiotype antibodies, and so on. Thus, an antibody is 


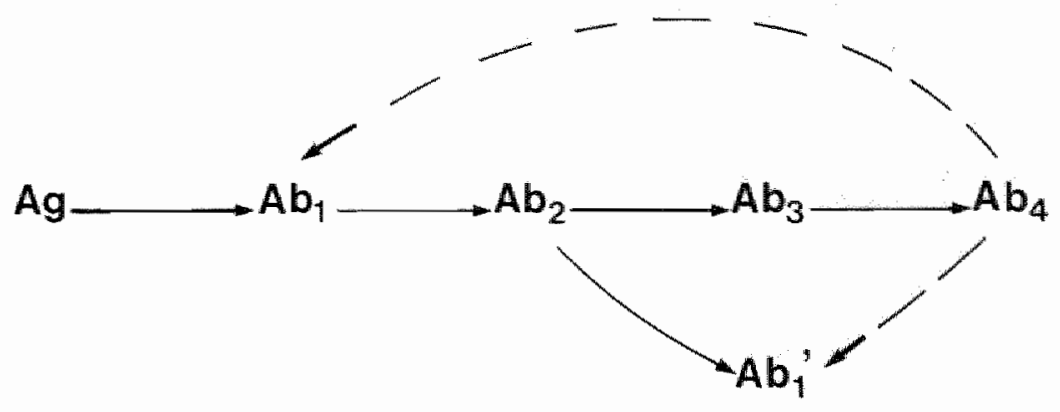

FIGURE 4.4 Idiotypic diversity does not increase along a chain of immunization. Full arrows indicate immunizations. Broken arrows indicate specific recognition. $A b_{3}$ and $A b_{l}$ antibodies are synthesized in the same animal. A sequential network has been studied by immunizing with $A b_{2}$, obtained after immunization with $A b_{1}$, obtained after immunization with antigen $(\mathrm{Ag}) . A b_{1}$ was used to induce $A b_{2}$ and so on. It was found that diversity does not increase along the chain of immunization, because a large part of $A b_{3}$ shares idiotopes with $A b_{1}\left(A b_{1}\right)$ and $A b_{4}$ behaves like $A b_{2}(151)$.

not by definition an anti-idiotype, but depending on the experimental conditions one antibody can be defined as idiotype and another as anti-idiotype. In discussing interactions between Id and anti-Id, the Id is often referred to as Ab1 (antibody 1), and the anti-Id is termed Ab2. An anti-anti-Id would be termed Ab3, and so on (Fig 4.4).

Anti-Id's can be classified according to the Id they recognize. So, it is possible to have anti-Id's directed at private or crossreactive Id's. However, anti-Id"s can also be categorized according to the sites of the variable region which they recognize. If an idiotope distant from the antigen binding site is recognized by an anti-Id, then antigen binding does not interfere with the Id anti-Id interaction (77). On the other hand if the anti-Id recognizes an idiotope near by or in the antigen binding site, the antigen is able to inhibit the binding of the anti-Id (77). Most blocking anti-Id's bind close to the antigen binding site and block the binding of the antigen by steric hinderance. It is generally assumed that anti-Id or antigen capable of blocking the binding of one another to the Id carriing antibody, do not necessarily have an identical threedimensional structure or bind by interaction with the same contact residues (117). Therefore, these anti-Id's may be structurally very different from the antigen. Anti-Id's mimicking the threedimensional conformation of the antigen are called 'internal images' $(56,67,120,122,150)$. The idealized internal image has the following properties (51):

a) It competes with the antigen $(X)$ for binding to the anti- $X$ binding sites.

b) It binds a substantial portion of the total anti- $X$ antibodies. 
c) It recognizes anti- $X$ antibodies from various strains and species.

d) Inoculation of an internal image anti-Id elicits an anti-anti-Id response which contains antibodies that resemble the original anti- $\mathrm{X}$ antibodies.

e) In instances where epitope $X$ is involved in the delivery of ligand function, e.g. hormone receptor binding, an anti-Id may either mimic or compete with this function.

Internal image antibodies have been shown to be able of mimicking the biological functions of hormones (67) or neurotransmitters (120). This is very useful as anti-Id's can be generated in absence of either purified ligand or receptor, and then these anti-Id's can be used for characterization of receptors, e.g. the beta-adrenergic receptor (56), and the cellular receptor of mammalian reovirus type 3 (28). Another application for internal image anti-Id's is vaccination. Vaccination with anti-Id's have been shown to protect against an infection with E. coli (135) and hepatitis B (107).

\section{Idiotype network}

In 1974 Jerne formulated the network theory of the immune system (17). This concept proposed that idiotypic interactions form a network which plays a crucial role in the regulation of the immune response. This network is based upon autoreactivity, with idiotopes on lymphocyte receptors being recognized by other lymphocytes in the same individual. In this way all idiotopes, and therefore also paratopes, were thought to be connected in a large idiotype network (17). Originally Jerne proposed that all idiotypic determinants were present on immunoglobulins. At that time, in 1974, the structure and genetic basis of the $\mathbb{T}$ cell receptor were still unknown. Nowadays, the idiotypic network is thought to involve both B cell immunoglobulins and $\mathrm{T}$ cell receptors (119).

Jerne proposed that there is a vectorial character in paratope-idiotope regulatory interactions. That is, interactions with receptors through their paratopes are stimulatory, while interactions trough the (framework) idiotopes of the same receptors are suppressive (17). Thus, if an anti-Id binds to idiotopes within the antigen binding site, this would be a stimulatory signal for the cell, while binding of an anti-Id to framework Id's would be suppressive. Later developments showed that that administration of the same anti-Id was able to enhance as well suppress an immune response (114).

Implicit to Jerne's original network theory was the fact that most Id's and anti-Id's are highly connected in a single network (17). He originally proposed an open ended network, where antigen induced and endless cascade of Id's and anti-Id's. Analysis of antibodies induced in a chain of immunizations using $A b 1$ to induce $A b 2, A b 2$ to induce $A b 3, A b 3$ to induce $A b 4$, etcetera, would therefore show increasing diversity 
along the chain of immunization (Fig 4.4). The major outcome of an immunization with $\mathrm{Ab} 2$, however, was not the induction of $\mathrm{Ab} 3$ antibodies which are anti-anti-Id, but rather molecules (termed Abl') which share Id's with the original Id $(13,142$, 151). Thus, the immune system should not be seen as one large pool of interacting Id's and anti-Id's, but rather as a collection of 'mini-networks'. To explain this construction, Paul and Bona proposed the existence of regulatory Id's, which would be the only Id's being immunogenic to a substantial degree in a syngeneic or autologous sytem (107). Thus, this concept states that only regulatory Id"s are interconnected prior to introduction of an antigen. Other 'conventional' Id's do not take part in this network. Thus, relatively small circular idiotype networks can be distinguished, which prevent the possibility that at the end of an induced Id-anti-Id cascade, one half of the idiotype repertoire is involved in recognizing the other half $(142,151)$.

Numerous studies now support a regulatory function of anti-Id antibodies both in autoimmune and allogeneic interactions between the immune system and the antigen $(9,22,50,58,114,136,137,155)$. Naturally occurring anti-Id's have been detected in myasthenia gravis patients (38), and patients with systemic lupus erythematosus (1). Studies concerning regulation by administration of anti-Id, generally involved only a single Id, rather than a true network of Id connections (39). However, some studies adress the issue of complex Id networks $(39,62,72,148)$. For example, Dwyer (39) described an extensive network of antibodies interconnected by Id's, in which anti-acetylcholine receptor antibodies were connected with anti-dextran antibodies, and Holmberg described an idiotypic network between $70 \operatorname{IgM}$ antibody clones from a non-immunized BALB/c mouse (62).

\section{Idiotype regulation of the immune system}

The Id system is operational not only when the immune system is challenged by an antigen, but also in the absence of antigenic challenge during a"steady state " $(68$, 157). This"steady state" can be disturbed by antigen, but also by idiotypes (118) and anti-idiotypes $(22,50,114)$. Administration of ld or anti-Id in modulating the immune response after antigenic challenge is able to result in enhancement (12) or suppression (148) of the immune response. In a physiological state the latter is relevant for the maintenance of tolerance (157), and in a disturbed, autoimmune state suppressive properties of Id or anti-Id might be used to restore a physiological balance. The enhancing effects could be the underlying critical event trough which the immune system loses its ability to down-regulate the continuously emerging auto-immune clones in order to maintain tolerance (157). 
These regulatory properties due to interactions between antibodies via Id's have been studied at two different levels (39):

\section{a) Development and maintainance of the $B$ cell repertoire.}

The observation that auto-antibodies and autoreactive B cells are demonstrable in a normal individuals (146) has led to a study of these so called "natural" antibodies and the development of the antibody repertoire (63). To study these antibodies in unmanipulated animals B cell hybridoma's were constructed of liver and spleen from foetal and neonatal animals $(64,144)$. These studies showed the early antibody repertoire in contrast to the adult $B$ cell repertoire to be highly connected in terms of idiotype $(62,64)$; in addition, the early IgM producing B cells have the potential to interact with a large number of self molecules (144). A hierarchy has been observed in antigen responsiveness in developing $B$ cells $(144,146)$, since newborn but not fetal mice have $B$ cells specific for polysaccharide antigens such as levans and phosphorylcholine $(127,146)$, and on the other hand $B$ cells specific for trinitrophenylated proteíns were found in the livers of fetal mice as early as sixteen to eighteen days of gestation (146). Administration of IgM monoclonal antibodies produced by neonatally derived hybridomas during the perinatal period resulted in distortion of the phophorylcholine specific B cell compartment and a reduction of antibody response to these antigens when challenged as adults $(145,146)$. In order to induce effect on the antibody response these IgM antibodies had to be adminstered during narrow time windows (e.g. between 4 and 7 days after birth) (144). Thus, it has been suggested that early idiotype directed interactions are essential for the establishment of the adult B cell repertoire (146). This ordered appearance of various B cell specificities, is in contrast with what one might have predicted from the knowledge of molecular mechanisms involved in the expression of immunoglobulin receptors. This is because of the B cell repertoire, resulting of random somatic events, would be expressed without control on specificity, different specificities should arise by chance in each individual during ontogeny, so that the repertoire of syngeneic neonates should diverge early in development. It has been observed, however, that $B$ cells with a given specificity occur at fixed point in time $(127,146)$. Molecular analysis suggest that there is non-random $V_{H}$ gene expression in the early $B$ cell repertoire in the sense that the most $3^{\prime} \mathrm{V}_{\mathrm{H}}$ families are rearranged and expressed at a much higher frequency than can be accounted for based on their prevalence in the genome, and that these genes appear to be used preferentially in pre-B cells (154) or young lymphocytes (108).

In adult animals a high frequency of $\mathrm{V}_{\mathrm{H}} 7183$ gene family expression was found in autoimmune NZB mice (7), and the analysis of the $V_{H}$ genes of a panel of 61 murine monoclonal autoantibodies showed that a restricted number of $\mathrm{V}_{\mathrm{H}}$ genes were used, namely $V_{H} J 558$, the largest family described sofar, and the most 3' families $V_{H}$ QPC52 and $V_{H} 7183$ (101). Similar findings were made in the analysis of murine 


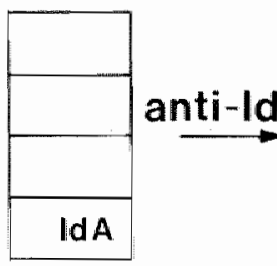

A

B

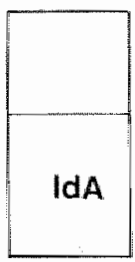

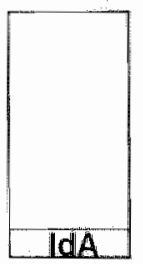

C

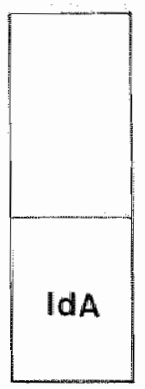

D

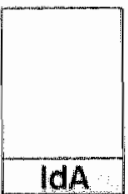

FIGURE 4.5 Results of idiotype manipulation by anti-Id. Modulation of the immune response by anti-Id may result in four possible situations: no change in total antibody titer against an antigen, but suppressedor enhanced Id expression $(\mathbf{A}, \mathbf{B})$, or quantative modulation of the total antibody response concomitantly with the idiotype (C,D).

rheumatoid factor antibodies (98). In additon CRI's were shared by these autoantibodies, even by antibodies using different $V$ gene families $(98,101)$. It is possible that these $V_{H}$ genes expressed in autoantibodies reflect an immature repertoire of $B$ or pre-B cells, because usage of the $\mathrm{V}_{\mathrm{H}} 7183$ gene family is infrequently used by mature B cells and frequently in early B cell development $(108,154)$. Alternatively, these $B$ cell expressing these $V_{H}$ genes were supposed to be representatives of a subset of the B cell lineage such as Ly-1 B cells (101). The Ly-1 cell surface marker was previously thought to be present only on $T$ cells, but then could be also demonstrated on B cells (99). These Ly-1 B cell lineage is reported to be highly represented in murine autoimmune strains (59), and secrete a high percentage of IgM autoantibodies (60). In man, an equivalent of these subset of B cells, the CD5+ B cell, is significantly increased in patients with rheumatoid arthritis (109). The production of all autoantibodies, as has been suggested in the analysis of a large array of autoantibodies (101), is probably not due to the activity of this B-cell population, since IgG autoantibodies are likely to be produced by IgG-bearing B cells, rather than Ly-1 B cells, which express IgM and $\operatorname{IgD}(60)$.

\section{b) Regulation of the immune response}

The validation of the existence of a functional network relies on the demonstration of CRI's $(8,52,70,78,106)$. The presence of CRI's on autoantiboides makes it conceivable that autoreactive clones can be controlled by anti-idiotypic manipulation (158). Many ways of manipulating immune responses might be especially 
worthwile in autoimmune diseases and autoimmunity $(30,31,97,112)$. Theoretically, four kinds of results can be obtained by anti-idiotype modulation of the immune response (Fig 4.5):

1) up regulation of the corresponding idiotype, without influencing the total immune response $(73,114)$.

2) down regulation of the corresponding idiotype, without influencing the total immune response $(22,73,114,137,148)$.

3 ) enhancement of the idiotype and the total antibody response (12).

4) suppression of the idiotype and total antibody response (50,136,148) or suppression of autoimmune disease $(21,58,155)$.

Several mechanisms have been proposed to explain the effects of anti-idiotype treatment. These include (97):

1) Direct effect on the B cell e.g. by clonal abortion, cell blockade (148), or induction of direct regulatory $\mathrm{B}$ cell interactions $(48,137)$.

2) Indirect modylation of the immune response by using anti-Id to stimulate $\mathrm{Id}$-specific $T$ suppressor cells, which can act on antigen specific $T$ helper cells and thus prevent autoreactive $B$ cells from receiving a second activation signal $(48,50,137)$

3) Use of toxin coupled anti-Id to directly eliminate autoreactive $T$ or B cells

Regardless of results obtained or mechanisrns proposed, several factors have been shown to determine the succes or failure of anti-Id modulation in an immune response.

First, the age of the animals has been shown repeatedly to influence results. Treatment of neonatal animals has resulted in a more profound and longer lasting suppression, compared to treatment of adult animals $(75,136)$. It has been suggested that this was due to a difference in mode of action; adult suppression would be a result of direct $B$ cell blockade and neonatal suppression would be induced by the activation of $T$ suppressor cells (138). Moreover, in treating newborn animalls it has been shown that an age difference of a few days might determine which Id's are regulated by anti-Id administration and which are not affected (144).

Next, the specificity of the anti-Id's is important, since it has been shown that not all anti-Id's, even if elicited against the same idiotype, are equally effective in modulating the idiotype immune response, when administered prior to immunization with antigen (22). Further, multuspecificity of $\operatorname{IgM}$ antibodies from perinatal developing $B$ cells is associated with regulatory functions in the early $B$ cell repertoire $(62,144)$.

Thirdly, the effect of anti-Id treatment has shown to be dose dependent, as has been observed in treating mice with nano- to microgram amounts of monoclonal anti-Id in the nitrophenyl (NP) Id system (73); the administration of low dosages (nanograms) resulted in enhancement, but high dosages (micrograms) resulted in suppression of the Id positive antibody response. 
Finally, the influence of class of passively transferred anti-Id is controversial, In the streptococcal carbohydrate associated A5A Id system IgG1 antibodies resulted in enhancement, and $\operatorname{IgG}_{2}$ anti-Id's were suppressive (42). In the NP Id system IgG anti-Id's enhanced or suppressed the Id positive response depending on the dose, and an $\mathrm{IgG}_{2 \mathrm{a}}$ anti-Id could only suppress the antibody immune response. In the same NP Id system, however, it was clearly shown that no differences could be found using different isotype-switch variants of the same anti-Id (102). In addition, no different functions for various Ig subclasses were found in the phophorylcholine Id system $(9,76)$. Therefore, it is assumed that in most idiotype systems differences in class do not determine differences in regulatory capacity.

\section{Idiotypes in myasthenia gravis}

\section{Introduction}

In the first years after Jerne presented the concept of the idiotype network most of the attention in the field of immunology has focused on antigen systems with small, well-characterized antigens. Examples of well known idiotypes in these systems are the phosphorylcholine-reactive myeloma protein TEPC-15 (26), the major idiotypes in the anti-azophenylarsonate system (79), the anti-bacterial levan (95), and antihen egg lysozyme responses (8). The antigens used in these studies are, however, relatively simple and elicited a more or less oligoclonal response. On the other hand, antibody immune responses against more complex antigens are involved in autoimmunity, like the polyclonal antibody response against the AChR.

The analysis of the role of Id-anti-ld networks may contribute to our understanding of the induction of autoimmunity (156), and have a potential application for antigen specific treatment $(50,136,148)$.

\section{Idiotype pathways for the induction of myasthenia gravis}

Anti-Id may contribute to the disease process by mimicking a ligand for binding to specific cellular receptors, which may then affect the function of the cell bearing that receptor. First, ligands can induce the production of antibodies carrying specific idiotopes. Next, anti-Id's are generated in response to the idiotype on these antibodies. A small fraction of these antibodies would be internal images, structurally similar to the original antigen. These anti-Id's, resembling the ligand, may bind the 
receptor and sometimes mediate similar physiological effects $(45,56,67,120,122$, 150). Anti-Id's elicited against anti-thyrotropin antibodies showed thyrotropin-like biological activity (67). Anti-Id's raised by immunization with anti-insulin antibodies showed an insulin-like activity (122). Anti-Id's elicited by immunization with an anti-reovirus $\mathrm{mAb}$ mimicked and inhibited the binding of the virus to the host cell (45).

Wasserman (150) undertook studies designed to address whether this anti-Id route could be used to induce an autoimmune antibody response against the AChR. Therefore three rabbits were immunized with antibodies directed against the synthetic AChR agonist BisQ. All three animals produced antibodies reactive with $A C h R$, titers were similar to that found in a patient with $M G$, and two rabbits showed signs of muscle weakness typical of experimental autoimmune myasthenia gravis. This indicates that a part of the anti-Id's elicited by the anti-BisQ antibodies resembled the original ligand, and were capable of binding to the AChR to such an extent that the neuromuscular transmission was impaired. Further, an important finding was the transient nature of the anti- $\mathrm{AChR}$ antibody titer and clinical signs of EAMG. This is explained by a normal Id-anti-Id network regulation, and suggests that the induction of auto-antibodies by itself is not enough to cause autoimmunity. Next, they extended their studies to mice (55). According to the network theory of Jerne, injection of an antigen elicits, in addition to antibodies to the antigen, other populations that include anti-idiotypic antibodies directed at the combining sites of the antigen-specific antibodies. They showed that, after immunization of mice with BisQ conjugated to bovine serum albumen, it was possible to isolate anti-anti-BisQ antibody secreting spleen cells. Monoclonal cell lines which were obtained after fusion of these cells with a myeloma line secreted anti-Id's binding to anti-BisQ antibodies, which also possessed AChR-binding capacities. These results lend support to a functioning idiotypic network, in which anti-Id's constitute a normal part of the immune response.

Another example of an anti-Id pathway which could lead to an antibody response to the AChR can be found in the immune response to the rabies virus. Although some investigators disagree (113), several reports indicate that the rabies virus may interact with the $\mathrm{AChR}(92,93,94)$, and therefore possess a receptor for the AChR. Moreover, evidence was presented that the amino-acid sequence of a segment of the rabies virus glycoprotein is similar to the sequence of long neurotoxins which bind to the AChR. The highest degree of similarity occurred with the amino acids that are highly conserved or invariant among all neurotoxins, including those residues that bind to the ACh binding site on the AChR (91). Like in the anti-BisQ response, a part of the anti-Id response against anti-rabies virus antibodies could represent internal images of the rabies virus and therefore have the ability to bind the $\mathrm{AChR}$ and contribute to the induction of $\mathrm{MG}$. 
These results do not suggest that $\mathrm{MG}$ is caused by rabies virus infection, but it suggests that structural similarity between parts of viruses or other micro-organisms may provide a basis for the pathogenesis of $\mathrm{MG}$, because an infection could be followed by the production of pathogenic anti-Id's recognizing the AChR $(20,110)$. Additional candidates for an infectious etiology of $\mathrm{MG}$, include bacteria, like Enterobacter cloaca and Serratia liquefaciens, both expressing dextran-like determinants. Dwyer $(39,41)$ discovered that anti-AChR and anti-anti-dextrane antibodies are interconnected by an idiotype circuit. Monoclonal antibody SR11 recog nized $\alpha-1,3$ dextran as well as the anti-AChR mAb ACR24. Ten of $60 \mathrm{MG}$ patients and none of 40 controls had serum antibodies against dextran (39), and $40 \%$ of more than $50 \mathrm{MG}$ patients had antibodies specific for ACR24 (38). In addition to bacterial infection, however, other factors such as the appropiate immune response genes, and immunoglobulin genes are probably necessary for the induction and development of MG.

Micro-organism and the potential auto-antigen might share antigenic determinants, instead of being complementary. Therefore molecular mimicry may play a role in autoimmunity. There is evidence that mammalian cells share antigenic determinants with virusses and parasites. Human intermediate filaments share epitopes with herpes simplex and measles virus (49), proteins in neurons infected by Chagas' disease share antigenic determinants with proteins of Trypanosoma cruzi (152), Escherichiae coli and Neisseria meningitides which can be a cause of bacterial meningitis have substances that react with brain gangliosides (130) and unspecified glycopeptides from human and rat brain (46). Immunological analysis of proteins from 10 species of bacteria for their reactivity with antibodies against the AChR in Western blots, revealed crossreactivity of anti-alpha subunit mAb's and membrane proteins of Escherichia coli, Klebsiella pneumoniae, and Proteus vulgaris (133, 134). These bacteria all belong to the normal flora of the gut, as the 60 human sera tested all contained antibodies against these bacterial proteins. Therefore possibly one of the primary events in MG is an exposure to antigenic determinants shared by normal bacterial flora and the AChR. This hypothesis circumvents the need for anti-Id's, and only postulates that antibodies with similar fine specificities, and probably similar idiotypes, are used in the response against antigenic determinants on certain micro-organism and the AChR. 


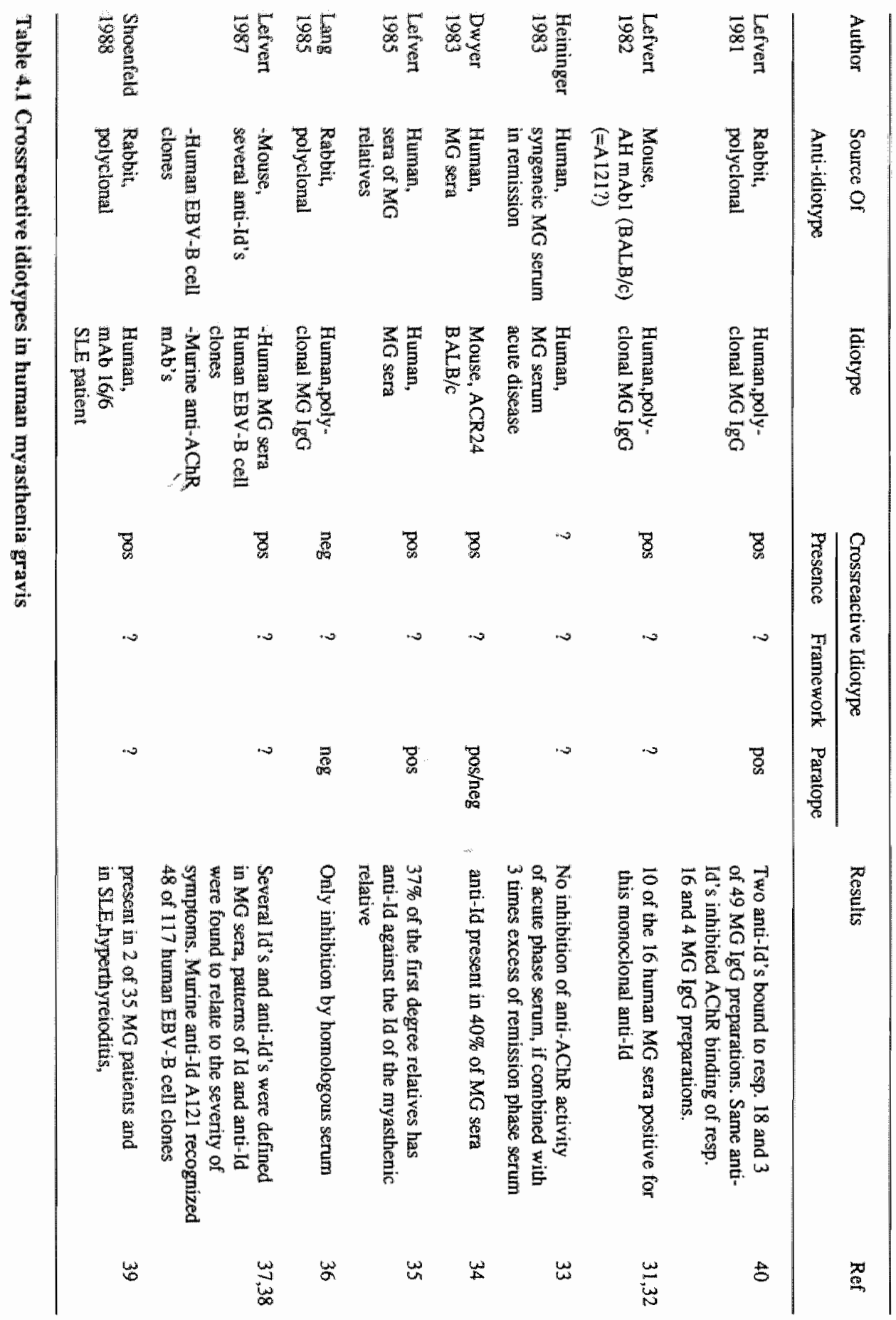




\section{Crossreactive idiotypes in human myasthenia gravis}

Analysis of expression of crossreactive idiotopes on anti-AChR antibodies enables to study idiotypic regulation of the immune response against the $\mathrm{AChR}$ and could form a possible means of specific immunotherapy of MG. Table 4.1 summarizes the available literature.

One of the first analyses of idiotypes on anti-AChR antibodies in $M G$ was reported by Lefvert (84). Polyclonal anti-idiotypic antibody preparations were raised in two rabbits, each of which was challenged with purified anti-AChR antibodies from a single MG patient. These polyclonal anti-Id's were used to analyse IgG preparations of 49 patients for the presence of CRI's. The anti-Id's bound to 18 and $3 \mathrm{MG} \mathrm{IgG}$ preparations respectively, and inhibited the binding of 16 and 4 MG IgG preparations. It was concluded that shared idiotypic specificities occured for anti-human AChR antibodies. One anti-Id, however, did not recognize the idiotype which was used to elicit the other. In addition, it is not clear how one of the anti-Id's could inhibit the binding to AChR of one of the MG IgG preparations, while no direct binding could be demonstrated. In further studies $(85,86,87,88,89)$ murine monoclonal anti-Id's, prepared against polyclonal IgG from MG patients, were used and also human Epstein-Barr virus transformed lymphoblastoid cell lines. A CRI was expressed on serum antibodies of 10 of $16 \mathrm{MG}$ patients using murine anti-Id $\mathrm{AH}$ mAbl $(85,86)$. Circulating autoanti-Id's against idiotypes of MG patients were demonstrated in $37 \%$ of the first degree relatives (87). Using peripheral mononuclear cells 117 Epstein-Barr transformed B cell lines were generated, expressing Id's as well as anti-Id's associated with MG. Out of 50 Id positive clones 48 bound the murine anti-Id A121 (also described as AH mAb1), indicating that this is a dominant idiotype in the immune response against the $A C h R(89)$. These studies identified several CRI's and anti-Id's in the immune response against the $A C h R$ in man. The prevalence of a number of Id's was correlated with the clinical stage of disease; patients with mild disease had a lower prevalence of the Id"s tested than severely affected patients (88). The presence of CRI's and autoanti-Id was also found by others $(38,125)$, but not by Heininger (61) and Lang (125). Dwyer (123) found circulating autoanti-Id's in the sera of MG patients. Six of $10 \mathrm{MG}$ patients appeared to have circulating anti-Id's which bound to a murine anti-AChR mAb ACR24. This binding could be inhibited by the antigen, but it was not shown whether the anti-Id's could also inhibit the binding of the AChR to ACR24. In 50 other MG patients $40 \%$ had antibodies specific for ACR 24 , so the Id recognized by this murine mAb might represent a widely shared crossreactive idiotope. It was concluded that autoanti-Id's may occur naturally during the course of myasthenia gravis. Shoenfeld (125) examined the sera of patients with MG for the presence of Id $16 / 6$. This Id had previously been found on antibodies in 54\% of SLE patients with active disease (66), has been associated with antibodies showing polyreactivity 
(104), and is probably encoded for by germline genes (125). Two of $35 \mathrm{MG}$ patients were found to express this Id. The presence of this Id in different patients with different diseases points to a limitation in the repertoire of the genes coding the variable region of autoantibodies. It is not clear whether this limitation is a genotypic one, reflecting the selection of individuals with a germline gene predisposing for autoirnmunity, or a phenotypic phenomenon, indicating a common pathophysiological mechanism leading to expression of these Id's in patients suffering from autoimmune diseases (125).

Heininger (61) tested the hypothesis that the increase and decrease of autoantibody titers during the various phases of an autoimmune disease are mediated by blocking anti-Id's. The antibody titers in sera during the active phase of disease, at the time of remission, and in mixtures with 3 to 20 -fold excess of remission phase serum over active phase serum were determined. Blocking anti-Id's, if present in the remission phase serum, should reduce the antibody titer in the combined sera compared to the arithmetic average of the two titers before combining. No blocking effect by the rerbission phase serum was found. Also no indications were obtained to support the idea that in remission phase serums all anti-Id's might be complexed with anti-AChR antibodies. Therefore it was concluded that in MG remission phase serum does not contain measurable amounts of free or complexed blocking antiId's.

Lang (81) did not find CRI's in $20 \mathrm{MG}$ patients. Anti-Id's were prepared in rabbits against affinity purified anti-AChR antibodies from three patients. Using an antigen precipitation radioimmunoassay only the binding of autologous anti- $A C h R$ antibodies to the AChR could be inhibited $(62-80 \%)$. These results differ from the abovementioned observations of Lefvert (85) who was using a similar radioimmunoassay for the detection of paratope related idiotypes. In both studies inhibition was only achieved using relatively high concentrations of anti-Id IgG. Moreover, Lang (81) reports a highly variable inhibiton by control rabbit serum (range 0$47.5 \%$ ), and therefore suggests that the different conclusions which are reached depend on the interpretation rather than on the results themselves.

In conclusion, the results of the studies discussed above do not allow unequivocal inferences. In some studies CRI's appear readily demonstrable, while others, using similar assays, only find private Id's and suggest a very heterogenic anti-AChR response. Further comparison of observations is often hampered by the fact that each study uses its own idiotypic and anti-idiotypic preparations, and no exchangeable monoclonal reagents are available. 


\section{Crossreactive idiotypes in experimental autoimmune myasthenia gravis}

Since a good animal model for human autoimmune $M G$ is available, the expression of idiotypes has been studied in animals with particular attention to inbred strains of rats and mice. Table 4.2 gives an overview of the literature

Polyclonal mouse anti-Id was used by Schwartz (121) to demonstrate a broad crossreactivity among polyclonal anti-AChR antibodies from 7 different mouse strains, and even anti-AChR antibodies from rat, rabbit and monkey. This was tested in a direct idiotype binding solid phase radioimmunoassay, which assay does not distinguish between paratope and framework idiotopes. However, inhibition of antigen binding (21-45.7\%) by the anti-Id was found in the 7 mouse strains, using an antigen precipitation assay $(81,85)$. These results suggest that at least part of the CRI was associated with the antigen binding site of anti-AChR antibodies. Crossreactivity between polyclonal anti-AChR antibodies was also reported by Valderrama (147) in rabbits. These anti-Id's showed maximal 35\% inhibiton of the binding of EAMG sera to AChR. Although crossreactivity was found in the direct binding, no information is given about paratope related crossreactivity.

In contrast to polyclonal antibodies the use of monoclonal antibody permits a more detailed analysis of idiotype expression on anti-AChR antibodies. Lennon (90) used 5 anti-AChR mAb's to look for paratope related CRI's. Syngeneic anti-Id"s detected a common Id on 4 of the $5 \mathrm{mAb}$ 's (all derived from two rats), as was demonstrated by $100 \%$ inhibiton by the anti-Id's of the binding of the mAb to AChR. Using an competitive inhibition assay, employing anti-Id-mAb 3 and labeled mAb 3 , six of 15 sera were found to be positive for the idiotype. This sugests that an antibody specificity was identified which occurs frequently in the autoantibody response triggered by immunization with Torpedo AChR. From the information available it is not clear if the determinant identified by these antibodies is the MIR. Dwyer (39) has discovered a high interconnectivity between the AChR and alpha-1,3-dextran antigen system. In this network crossreacting anti-AChR antibodies can be found which are anti-Id's in the anti- $\alpha-1,3$-dextran immune response. Moreover, some of the antibodies connect the system with even other antigen systems. In contrast to most other studies, they concentrate on connections within the immune system via Id's, and are not analyzing the frequency of CRI's in the immune response against one single antigen $(38,39)$. These studies extend the knowledge about possible regulatory interactions. They have shown a hierarchical organization with a central role for a number of IgM antibodies, which were termed "superorganizers" (39). Agius (3) produced 5 syngeneic anti-Id's against 2 anti-AChR mAb"s. The results suggest that all five anti-Id tested inhibit the binding of AChR by an allosteric effect upon the paratope of the $\mathrm{mAb}$, but no paratope related idiotopes were identified which could be candidates for internal image anti-Id's. Recognition of CRI's on the 


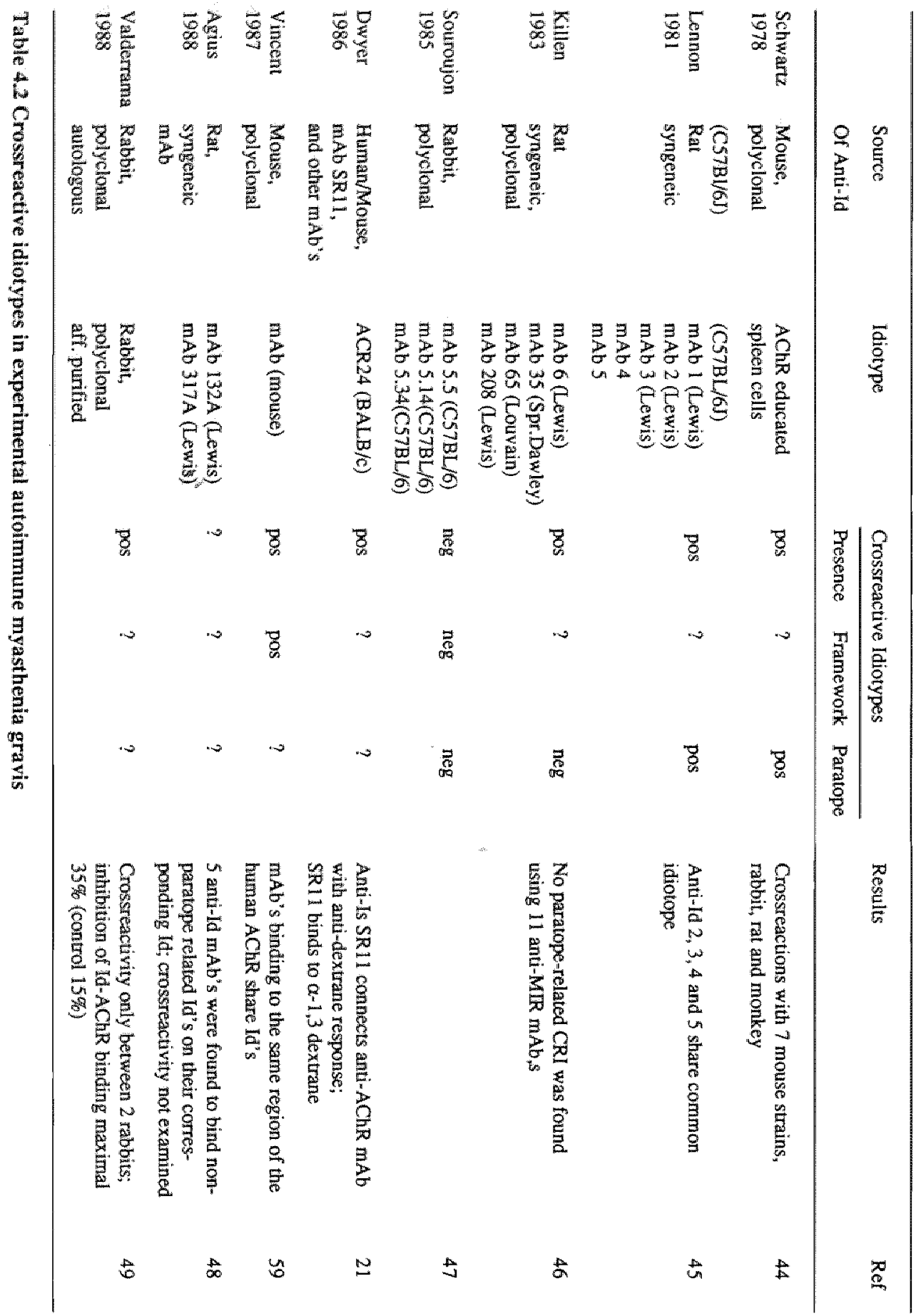


non homologous anti-AChR was not tested. They suggest that this allosteric modulation of the binding of $A C h R$ to anti-AChR antibodies (or AChR-receptors) could play a role in regulation of the immune response.

Not all studies were succesful in finding crossreactive idiotopes on anti-AChR antibodies $(74,131)$. Souroujon (131) used polyclonal rabbit anti-Id's to analyze the idiotypes of 3 anti-AChR mAb's. All 3 anti-Id's recognized the homologous Id, against which they were elicited, and inhibited its binding to AChR. However, no crossreaction with other anti-AChR mAb's or inhibition of AChR binding by these mAb's was found. This is in contrast to the results published previously by the same group (121), in which they found extensive allo- (various strains of mice) and xeno(mice and rabbit) crossreactivity. However, they also report that rabbit anti-Id against polyclonal mouse (C57BL/6) anti-AChR antibodies inhibit up to $42 \%$ of the binding of various mouse anti-AChR antibodies to $A C h R$ when compared to normal rabbit serum (131). Apparantly the interstrain CRI's in mice are more abundant than in rabbits. Killen (74) performed a thorough and detailed analysis of paratope related CRI's on 11 well defined anti-MIR anti-AChR mAb's $(139,140,141)$. Of all anti-MIR mAb's, mAb 35 is the most well-known monoclonal antibody, since $\mathrm{mAb}$ 35 binds well to AChR's from virtually every species tested (74). Unlike Lennon (90) very little paratope related crossreactivity of anti-Id"s prepared against mAb 35 and $\mathrm{mAb} 208$ was found. Although two high titer anti-ld's raised against mAb 35 crossreacted with mAb 37. Interestingly, this $\mathrm{mAb} 37$ ( $\mathrm{IgG2a}$ ) had been produced in the same Sprague-Dawley at which produced $\mathrm{mAb} 35$ (IgG1). It is suggested that this might also form the explanation for the crossreactivity observed by Lennon (90), as 3 of their 4 crossreacting mAb's were derived from a single rat.

Vincent used the human AChR to produce anti-AChR mAb's in mice (149). Competition experiments showed that the monoclonal antibodies bound to 5 partially overlapping regions on denervated human AChR. Two regions (region 3 and 4) were similar to the MIR, as proposed by Tzartos and Lindstrom, as was demonstrated by the inhibition studies using mAb 35 . CRI's were present on anti-AChR mAb"s binding to the same region, but CRI's were not shared by anti-AChR $m A b$ "s binding to different regions. The conclusion is reached that, although more than $50 \%$ of the anti-AChR antibodies compete for binding to the MIR, this immunodominance of the MIR is not reflected in the presence of a dominant idiotope in the binding sites of these antibodies.

In conclusion, there is no common opinion regarding the existence of CRI's on anti-AChR antibodies in EAMG. Although the use of experimental animals and the availability of $\mathrm{mAb}$ 's offers considerable potential for elaborate research, no unequivocal results have been obtained. Some groups find extensive CRI's (121), while others observe only few crossreactions $(74,149)$. Reports from the same group $(121,131)$ may differ considerably for the frequency with which they observe CRI's. 
Moreover, some investigators use a different point of view and do not describe the prevalence of CRI's, but are interested in network interactions (39) or introduce (another) theory of immune modulation (3). In addition, most studies only analyze paratope related Id's at the expense of framew ork related Id's.

\section{Anti-idiotypic and idiotypic manipulation of the immune response against the acetylcholine receptor}

Several approaches have been used for antiidiotypic or idiotypic manipulation of the autoantibody response against the AChR and to prevent disease. First, auto-anti-Id's were elicited by immunization with an anti-AChR mAb before immunization with AChR $(74,90,131)$ or during immunization with AChR (147). Another approach was by passive transfer of anti-Id to prevent acute EAMG $(2,74,132)$. Further, adoptive transfer has been performed with lymphocytes from animals with EAMG treated in vitro by anti-id complexed to ricin $(23,37)$. These data are summarized in Table 4.3.

Lennon (90) tested the feasibility of repeated immunization of rats with a mAb, capable of inducing myasthenia gravis and expressing a CRI, as a means of protecting rats from EAMG induced by immunization with Torpedo AChR. After repeated immunization during a period of 6 months rats were immunized twice with Torpedo AChR. No significant differences in titer were seen compared to control groups, although all rats had detectable anti-Id in their serum upto the end of the experiment. Killen (155) performed similar experiments using mAb's against the MIR (mAb 35 and 208) or polyclonal affinity purified rat anti-Torpedo antibodies. $\mathbb{R}$ ats were immunized with one of these antibody preparations coupled to lipopolysaccharide (LPS) or haemocyanin. High levels of anti-Id's were demonstrable in the rats immunized with the anti-AChR mAb's, but no detectable anti-Id's were found in the animals immunized with polyclonal anti-AChR antibodies. Analysis of the effects on the antibody response against the AChR did not reveal differences in titer between the experimental and control groups. Opposite results were found by Souroujon (131) in mice immunized with anti-AChR mAb's or polyclonal anti$A C h R$ antibodies before immunization with Torpedo AChR. Similar to the results of Killen (74) no CRI's were found on these mAb's, as described above. It was found, however, that preimmunization with these mAb's led to a significant suppression of the immunizing Id and in some cases also of another Id. Preimmunization with these mAb's or with polyclonal mouse anti-AChR antibodies reduced to anti-Torpedo titer $60 \%$ to $98 \%$. No correlation was found between the representation of a certain Id and the suppressive effect of its respective anti-Id. They favor the explanation that the suppressive effect was mediated by $T$ cell regulation. Clearly, simple neutralization of idiotype by anti-Id is probably inadequate for explanation of these phenomenon, since they found no CRI's on the mAb's that 


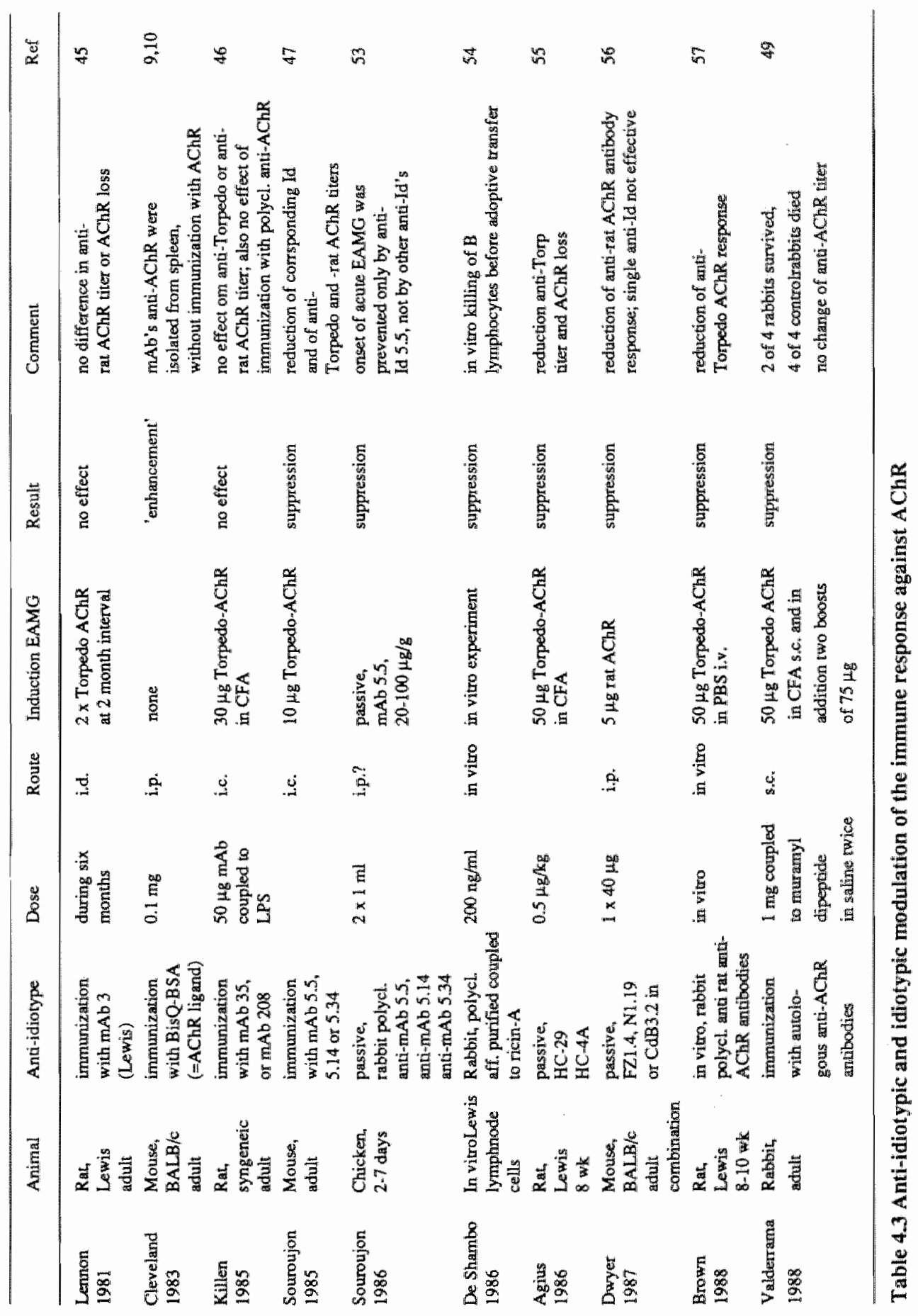


were used, suggesting that these mAb's cannot be blocked by the same anti-Id. Another succesful treatment of EAMG by immunization with anti-AChR anti-Id was reported by Valderrama (147). Here, a quite different technique was used for rabbits were immunized with their autologous anti-AChR antibodies coupled to muramyl dipeptide (MDP). MDP is an antigen from the tubercle baccillus cell wall, responsible for a large part of the adjuvant effect of complete Freund adjuvant (83). Two of four treated animals survived a second immunization with Torpedo AChR, in the control group all 4 animals died. Survival was not related to the level of anti-Id, and no change in anti-Torpedo AChR titer nor a difference in titers between control and experimental group was observed. It is not quite clear how anti-Id's can be demonstrated in rabbits with a high titer of anti-AChR antibodies, but this study is the first demonstration of succesful treatment of an ongoing myasthenic treatment after immunization with Torpedo AChR. A few years earlier Souroujon (132) had demonstrated a succesful treatment of passively transferred EAMG. Adminstration of anti-Id, starting 6 to 18 hours after injection of chickens with an anti-AChR mAb ( $\mathrm{mAb} 5.5$ ), resulted in recovery from the symptoms of most of the animals (10 of the 12). In the controlgroup, treated with normal rabbit $\mathrm{IgG}, 3$ of the 6 recovered. Symptoms of EAMG, induced by injection with an anti-AChR mAb (mAb 5.5) in chickens could also be prevented by adminstration of the homologous, but not by the heterologous, rabbit anti-Id's (in contrast to immunization with these mAb's, which suppressed the total anti-AChR response, as discussed above).

Similar studies were performed by Agius (2) and Dwyer (40), who have studied the effect of passive transfer of anti-Id's on the immune response against the AChR. Agius administrated a low $(0.5 \mu \mathrm{g} / \mathrm{kg})$ or high $(0.5 \mathrm{mg} / \mathrm{kg})$ dose of anti-Id mAb's (anti-Id HC-4A or HC-29) to adult Lewis rats. Four rats treated with the high dose anti-Id had significantly lower anti-AChR titers than in the rats treated with low dose, and they did not show AChR loss. Anti-Id could be demonstrated in all rats treated with the high dose, and also in approximately $75 \%$ of the rats that were not treated or with al low dose anti-Id. No correlation was found between anti-Id level and degree of protection as determined by receptor content. These effects are explained by assuming an regulatory effect of anti-Id binding to Id. The anti-Id's which were used do not compete with AChR for the binding to Id, but allosterically inhibit AChR binding. This allosteric reduction in avidity of $B$ and $T$ cell receptors is proposed as the basis for the regulation as observed in these experiments. Dwyer (40) performed similar experiments in mice. BALB/c mice were injected with $40 \mu \mathrm{g}$ syngeneic anti-AChR anti-Id (FZ1.4, N1.19, CdB3.2 or a combination) two weeks prior to immunization with purified rat muscle AChR. In contrast, to Agius (159) no effect of administration of a single anti-id was observed. On the other hand after pretreatment with a combination of anti-Id's a reduction in anti-AChR titers was observed in 3 of 4 experiments. 
Krolick et al $(23,37)$ used a quite different approach to develop specific immunotherapies for $M G$. They used affinity purified rat anti-AChR antibodies to elicit polycional anti-Id's in rabbits. These antibodies were used to prepare antibody-ricin A chain conjugates, and to treat lymphocytes from AChR immunized rats in vitro. These cell were transferred to irradiated, immunologically naive recipients. It was observed that these recipients failed to respond to soluble i.v. antigen challenge. In the previous study (37) selective in vitro inhibition of an anti-AChR response was demonstrated using this system.

In conclusion, the results reached by anti-Id therapies in EAMG are very divers, and no unequivocal interpretation is possible. On one hand immunization with mAb's carrying a CRI (90) or void of CRI (74) does not influence the immune response to subsequent immunization with $A C h R$, on the other hand immunization with a $m A b$, apparently without CRI (131), supresses the anti-AChR titer up to $95 \%$. Similarly, immunization of rats with polyclonal rat anti-AChR antibodies does not influence the response to AChR (74), but immunization of mice with polyclonal mouse anti-AChR antibodies results in a reduction of $98 \%$ of the anti-AChR titer (131). One study (2) observes a powerful effect on the $\mathrm{AChR}$ antibody response and $\mathrm{AChR}$ content by prior administration of one anti-Id $\mathrm{mAb}$, another study reports that only a combination of anti-Id's, but not a single anti-Id, was effective (40).

Apparently, most interventions using active or passive immunization for the treatment with anti-Id's are designed to make use of a direct blocking effect of anti-Id's in order to manipulate the antibody response or (physiological) Id-anti-Id network interactions. When a therapeutic effect is observed, however, the explanations are very different. Several mechanisms are proposed, including clonall deletion of B cells (131), T cell regulation (131), neutralization by blocking idiotype $(131,147)$, interference with AChR bound antibody (132), allosteric inhibition of AChR binding by Id (2), induction of the production of endogenous anti-Id's in vivo (40).

In contrast, the goal of immunotoxin therapy clearly is the elimination of autoreactive B cell clones against the AChR. This might be a useful strategy to eliminate autoreactive cells that minimizes the ambiguities of the Id-anti-Id network while exploiting the clonal selectivity of surface-expressed Id.

All studies discussed and published sofar were performed in adult animals, and no attempts were made to influence the neonatal Id-anti-Id network in order to determine whether or not this would result in an altered autoantibody response after immunization with the AChR. 


\section{References}

1. Abdou $\mathrm{NI}_{\text {, Wall }} \mathbf{H}$, Lindsley HB, Halsey JF, Suzuki T (1981) Network theory in autoimmunity. In vitro suppression of serum anti-DNA antibody binding to DNA by anti-idiotypic antibody in systemic lupus erythematosus. J Clin Invest 67:1297-1304

2. Agius MA, Richmam DP (1986) Suppression of development of experimental autoimmune myasthenia gravis with isogeneic monoclonal antiidiotypic antibody. J Immunol 137:2195-2198

3. Agius MA, Geannopoulos CJ, Fairclough RH, Richman DP (1988) Monoclonal anti-idiotypic antibodies against myasthenia-inducing anti-acetylcholine receptor monoclonal antibodies. J Immunol 140:62-68

4. Alt F, Baltimore D (1982) Joining of immunoglobulin heavy chain gene segments: Implications from a chromosome with evidence of three D-J fusions. Proc Natl Acad Sci $79: 4118-4122$

5. Bandeira A, Coutinho A, Martinez C, Pereira P (1988) The origin of "natural antibodies" and the internal activity in the immune system. Intern Rev Immunol 3:47-58

6. Bazin H, Lebacq AM (1983) Physicochemical and biological properties of rat antibodies. Transpl Proc XV:1669-1671

7. Bellon B, Manheimer-Lory A, Monestier M, Moran T, Dimitriu-Bona A, AIt F, Bona C (1987) High frequency of autoantibodies bearing cross-reactive idiotopes among hybridomas using $V_{H} 7183$ genes prepared from nomal and autoimmune murine strains. J Clin Invest 79:1044-1053

8. Benjamin CD, Miller A, Sercarz EE, Harvey MA (1980) A predominant idiotype on anti-hen egg white lysozyme antibodies from diverse mouse strains. J Immunol 125:1017-1025

9. Berek C (1983) Antibodies specific for different T15 idiotopes induce neonatal suppression of the T15 idiotype. Eur J Immunol 13:766-772

10. Berek C (1984) The D segment defines the T15 idiotype: The immune response of $\mathrm{A} / \mathrm{J}$ mice to Pneumococcus pneumoniae. Eur J Immunol 14:1043-1048

11. Berman PW, Patrick J (1980) Linkage between the frequency of muscular weakness and loci that regulates immune responsiveness in murine experimental myasthenia gravis. J Exp Med 152:507-520

12. Bluestone JA, Sharrow SO, Epstein SL, Oxato K, Sachs DH (1981) induction of anti-H-2 antibodies without alloantigen exposure by in vivo administration of anti-idiotype. Nature 291:233-235

13. Bona CA, Heber-Katz E, Paul WE (1981) Idiotype-anti-idiotype regulation. I. Immunization with a levan-binding myeloma protein leads to the appearance of auto-anti(anti-idiotype) antibodies and to the activation of sillent clones. J Exp Med 153:951-967

14. Bona CA, Goldberg B, Rubinstein LJ (1984) Regulatory idiotopes, parallel sets and internal image of the antigen within the polyfructosan-A48 idiotypic network. Ann Immunol (Inst Pasteur) 135C:107-115

15. Bona C (1987) In: Regulatory idiotopes, C Bona Ed, John Wiley \& Sons, New York, p. 24 
16. Bona C (1987) In: Regulatory idiotopes, C Bona Ed, John Wiley Sons, New York; p. 155

17. Bona C (1987) In: Regulatory idiotopes, C Bona Ed, John Wiley \& Sons, New York, p. 168

18. Bosma MJ, De Witt C, Hausman SJ, Marks R, Potter M (1977) Serological distinction of heavy chain variable regions ( $V_{H}$ subgroups) of mouse immunoglobulins. I. Common $\mathrm{V}_{\mathrm{H}}$ determinants on the heavy chains of mouse myelona proteins having different binding sites. J Immunol 146:1041-1053

19. Bothwell ALM, Paskind M, Reth M, Imanishi-Kari T, Rajewsky K, Baltimore D (1982) Somatic variants of murine immunoglobulin lambda light chains. Nature 298:380382

20. Bradley RJ (1984) Myasthenia gravis and the anti-idiotype theory of autoimmunity (letter). Lancet 1:396

21. Brown CA, Carey K, Colvin RB (1979) Inhibition of autoimmune tubulointerstitial nephritis in guinea pigs by heterologous antisera containing anti-idiotype antibodies. $\mathrm{J}$ Immunol 123:2102-2107

22. Brown AR, Sealy RE (1986) Regulation of the BALB/c anti-p-azophenylarsonate antibody response by monoclonal anti-idiotype. II. Idiotope expression in serum and its regulation. J Immunol 137:610-617

23. Brown RM, Krolick KA (1988) Selective idiotype suppression of an adoptive secondary anti-acetylcholine receptor antibody response by immunotoxith treatment before transfer. J Immunol 140:893-898

24. Burrage TG, Tignor GH, Smith AL (1985) Rabies virus binding at neuromuscular junctions. Virus Reseanch 2:273-289

25. Capra JD, Kehoe JM (1975) Hypervariable regions, combining site and antigen combining site. Adv Immunol 20:1-40

26. Cerny J, Wallich R, Hammerling GJ (1982) Analysis of T15 idiotopes by monoclonal antibodies: variability of idiotopic expression on phosphorylcholine-specific lymphocytes from individual inbred mice. J Immunol 128:1885-1891

27. Cleveland WL, Wassermann NH, Sarangarajan R, Penn AS, Erianger BF (1983) Monoclonal antibodies to the acetylcholine receptor by a normally functioning auto-antiidiotypic mechanism. Nature 305:56-57

28. Co MS, Gaulton GN, Fields BN, Greene MI (1985) Isolation and biochemical characterization of the mammalian reovirus type 3 cell-surface receptor. Proc Natl Acad Sei 82:1494-1498:

29. Cohn $\mathbf{M}$ (1986) The concept of functional idiotype network for immune regulation mocks all and comforts none. Ann Inst Pasteur Immunol 137:64-76

30. Cooke A, Lydyard PM, Roitt IM (1983) Mechanisms of autoimmunity: a role for cross-reactive idiotypes. Immunol Today $4: 170-175$

31. Cooke A, Lydyard PM, Roitt IM (1984) Autoimmunity and idiotypes. Lancet 2:723725

32. Cosenza $H_{3}$ Köhler $\mathbf{H}$ (1972) Specific suppression of the antibody response by antibodies to receptors. Proc Natl Acad Sci 69:2701-2705 
33. Cosenza H, Julius MH, Augustín AA (1977) Idiotypes as variable region markers: analogies between receptors on phosphorylcholine-specific $T$ and $B$ lymphocytes. Immunol Rev $34: 3-33$

34. Croce CM, Shander M, Martinis J, Cicurel L, D'Ancona GG, Dolby TW, Koprowski H (1979) Chromosomal localization of the genes for human immunoglobulin heavy chains. Proc Natl Acad Sci USA 76:3416-3419

35. Cronkhite RI, Cerny J (1986) A novel idiotypic determinant on phosphorylcholinebinding immunoglobulins restricted to isotype and allotype. I Immunol 136:3729-3733

36. D'Eustachio P, Bothwell ALM, Takaro TK, Baltimore D, Ruddle FH (1981) Chromosomal localization of the structural genes encoding murine immunoglobulin lambda light chains. J Exp Med 163:793-800

37. DeShambo R, Krolick KA (1986) Selective in vitro inhibition of an antibody response to purified acetylcholine receptor by using anti-idiotypic antibodies coupled to the $A$ chain of ricin. J Immunol 137:3135-3139

38. Dwyer DS, Bradley RJ, Urquhart CK, Kearney JF (1983) Naturally occurring anti-idiotypic antibodies in myasthenia gravis patients. Nature 301:611-614

39. Dwyer DS, Vakil M, Kearney JF (1986) Idiotypic network connectivity and a possible cause of myasthenia gravis. IExp Med 164:1310-1318

40. Dwyer DS, Schonbeck S (1987) Anti-idiotypic regulation of the immune response against the acetylcholine receptor. Imm Reg Char Peptides 607-616

41. Dwyer DS, Vakil M, Bradley RJ, Oh SJ, Kearney JF (1987) A possible cause of myasthenia gravis: idiotypic netwotks involving bacterial antigens. Proc Natl Acad Sci $505: 461-471$

42. Eichmann K (1974) Idiotype suppression. I. Influence of the dose and of the effector functions of anti-idiotypic antibody on the production of an idiotype. Eur $J$ Immunol 4:296-302

43. Eichmann $\mathbf{K}$ (1978) Expression and function of idiotypes on lymphocytes. Adv Immunol 26:195-254

44. Erickson J, Martinis J, Croce C (1981) Assignment of the genes for human lambda immunoglobulin chains to chromosome 22. Nature 294:173-175

45. Fields BN, Greene MI (1982) Genetic and molecular mechanisms of viral pathogenesis: implications for prevention and treatment. Nature 300:19-23

46. Finne J, Leinonen M, Makela PH (1983) Antigenic similarities between brain components and bacteria causing meningitis: implications for vaccine development and pathogenesis. Lancet 2:355-7

47. Fleischman JB, Davie JM (1984) Immunoglobulins: allotype and idiotypes. In: Fundamental Immunology, WE Paul Ed, Raven Press, New York pp 205-219

48. Freutas AA, Burlen O, Coutinho A (1988) Selection of antibody repertoires by anti-idiotypes can occur at multiple steps of B cell differentiation. J Immunol 140:40974102

49. Fujinami RS, Oldstone MBA, Wroblewska Z, Frankel ME, Koprowski H (1983) Molecular mimicry in virus infection: crossreaction of measles virus phosphoprotein or of herpes simplex virus protein with human intermediate filaments. Proc Natl Acad Sci 80:2346-50 
50. Fung $\mathbf{J}$, Kohler $\mathbf{H}(1980)$ Mechanism of neonatal idiotype suppression. II. Alterations in the $\mathrm{T}$ cell comparment suppress the maturation of $\mathrm{B}$ cell precursors. I Immunol 125:2489-2495

51. Gaulton GN, Greene MI (1986) Idiotypic mimicry of biological receptors. Am Rev Immunol 4:253-280

52. Gearhart $\mathbf{P}$, Cebra $\mathbf{J} J$ (1978) Idiotype sharing by murine strains differing in immunoglobulin allotype. Nature $272: 264-265$

53. Gearhart PJ, Johnson ND, Douglas R, Hood L (1981) IgG antibodies to phosphorylcholine exhibit more diversity than their IgM counterparts. Nature 29 1:29-34

54. Gearhart PJ (1982) Generation of immunoglobulin variable gene diversity. Immunol Today 3:107-112

55. Goverman J, Hunkapiller T, Hood L(1986) A speculative view of the multicomponent nature of $\mathrm{T}$ cell antigen recognition. Cell $45: 475-484$

56. Guillet JG, Kaveri SV, Durieu O, Delavier C, Hoebeke J, Strosberg AD (1985) Beta-Adrenergic agonist activity of a monoclonal anti-idiotypic antibody. Proc Nat Acad Sci 82:1781-1784

57. Gutman GA, Bazin H, Rokhlin OV, Nezlin RS (1983) A standard nomenclature for rat immunoglobulin allotypes. Transpl Proc XV:1685-1686

58. Hahn BH, Ebling FM (1983) Suppression of murine lupus nephritis by administration of an anti-idiotypic antibody to anti-DNA. J Immunol 132:187-190

59. Hayakawa K, Hardy RR, Parks DR, Herzenberg LA (1983) The Ly1 B cell subpopulation in normal, immunodefective and autoimmune mice. J Exp Med 157:202-218

60. Hayakawa K, Hardy RR, Honda M, Herzenberg LA, Steinberg AD, Herzenberg LA (1984) Ly1 B cells: functionally distinct lymphocytes that secrete IgM autoantibodies. Proc Natl Acad Sci 81:2494-2498

61. Heininger K, Hendricks M, Toyka KV, Kolb H (1983) Myasthenia gravis: remission not induced by blocking anti-idiotypic antibodies. Muscle Nerve 6:386-387

62. Holmberg D, Forsgren S, Ivars F, Coutinho A (1984) Reactions among IgM antibodies derived from normal, neonatal mouse. Eur J Immunol 14:435-441

64. Holmberg D, Wennerström G, Andrade L, Coutinho A (1986) The high idiotypic connectivity of"natural"newborn antibodies is not found in adult mitogen-reactive B cell repertoires. Eur $J$ immunol 16:82-87

63. Holmberg D, Coutinho A (1985) Natural antibodies and autoimmunity. Immunol Today $6.356-357$

65. Idiotypes of immunoglobulins (1982) In: Introduction to molecular immunology, A Nisonoff Ed, Sinauer Asscociates Inc, Sunderland pp.129-140

66. Isenberg DA, Madaio MP, Reichlin M, Shoenfeld Y, Rauch J, Stollar BD, Schwartz RS (1984) Anti-DNA antibody idiotypes in systemic lupus erythematosus. Lancer 2:417-422

67. Islam-MN, Pepper BM, Briones-Urbina R, Farid NR (1983) Biological activity of anti-thyrotropin anti-idiotypic antibody. Eur J Immunol 13:57-63

68. Jerne NK (1974) Towards a network theory of the immune system. Ann Immunol $125 \mathrm{C}: 373-389$

69. Jeske DJ, Capra JD (1984) Immunoglobulins: structure and function. In: Fundamental Immunology, WE Paul Ed, Raven Press, New York pp 131-165 
70. Karoll $\mathbf{R}$, Reichlin $\mathbf{M}_{\text {, Nobles }} \mathbf{R W}$ (1978) Idiotypic crossreactivity between antibodies of different specificities. I Exp Med I48:1488-1497

71. Kearney JF, Barletta R, Quare ZA, Quintans J (1981) Monoclonal versus heterogenous anti-HOPC8 antibodies in the analysis of anti-phosphorylcholine response in BALB/c mice. Eur J Immunol 11:877-883

72. Kearney JF, Vakil M (1986) Functional idiotype networks during B-cell ontogeny. Ann Immunol (Inst Pasteur) $137 \mathrm{C} \cdot 77-82$

73. Kellsoe G, Reth M, Rajewsky K (1981) Control of idiotope expression by monoclonal anti-idiotope and idiotope-bearing antibody. Eur J Immunol 11:418-423

74. Killen JA, Hochschwender SM, Lindstrom JM (1985) The main immunogenic region of acetylcholine receptors does not prowoke the formation of antibodies of a predominant idiotype. J Neuroimmunol 9:229-241

75. Köhler H, Kaplan DR, Strayer DS (1974) Clonal depletion in neonatal tolerance. Science 186:643-644

76. Köhler H, Richardson BC, Rowley DA, Smyk S (1977) Immune response to phosphorylcholine. III. Requirement of the Fc portion and equal effectiveness of IgG subclasses in anti-receptor antibody-induced suppression. J Immunol 119:1979-1986

77. Köhler H (1984) The immune network revisited. In: Idiotypy in biology and medicine, H Köhller, J Urbain, P-A Cazenave Eds, Academic Press, Orlando, pp. 3-14

78. Kohna Y, Berkower I, Minna J, Berzofsky JA (1982) Idiotypes of anti-myoglobulin antibodies: shared idiotypes among monoclonal antibodies to distinct determinants of sperm whale myoglobulin. J Immunol 128:1742-1748

79. Kuettner MG, Wang A-L, Nisonoff A (1972) Quantative investigations of idiotypic antibodies. VI. idiotypic specificity as a potential genetic marker for the variable regions of mouse immunoglobulin polypeptide chains. J Exp Med 135:579-595

80. Kunkel HG, Mannick M, Williams RC (1963) Individual antigenic specificity of isolated antibodies. Science 140:1218-1219

81. Lang B, Roberts AJ, Vincent A, Newsom-Davis J (1985) Anti-acetylcholine receptor idiotypes in myasthenia gravis analysed by rabbit antisera. Clin Exp Immunol 60:637-644

82. Langman RE, Cohn M (1986) The 'complete" idiotype network is an absurd immune system. Immunol Today 4:100-101

83. Lederer E, Adam A, Ciorbaru R, Petit JF, Wietzerbin J (1975) Cell walls of mycobacteria and related organism: chemistry and immunostimulant properties. Mol Cell Biochem 7:87-104

84. Lefvert A-K (1981) Anti-idiotypic antibodies against the receptor antibodies in myasthenia gravis. Scand J Immunol 13:493-497

85. Lefvert A K , James RW, Alliod C, Fulpius BW (1982) A monoclonal anti-idiotypic antibody against anti-receptor antibodies from myasthenic sera. Eur J Immunol 12:790792

86. Lefvert A-K, Fulpius BW (1984) Receptor-like activity of a monoclonal anti-idiotypic antibody against an anti-acetylcholine receptor antibody. Scand J Immunol 19:485-489

87. Lefvert A-K, Pirskanen R,Svanborg E (1985) Anti-idiotypic antibodies, acetylcholine receptor antibodies and disturbed neuromuscular function in healthy relatives to patients with myasthenia gravis. J Neuroimmunol 9:41-53 
88. Lefvert A-K, Holm G, Sunden H, Pirskanen R (1987) Cellular production of antibodies related to the acetylcholine receptor in myasthenia gravis: correlation with clinical stage. Scand I Immunol 25:265-273

89. Lefvert A-K, Holm G (1987) Idiotypic network in myasthenia gravis demonstrated by human monoclonal B-cell: lines. Scand J Immunol 26:573-578

90. Lennon VA, Lambert EH (1981) Monoclonal autoantibodies to acetylcholine re ceptors: evidence for a dominant idiotype and requirement of complement for pathogenicity. Ann N Y Acad Sci 377:77-96

92. Lentz TL, Chester J, Benson RJJ, Hawrot E, Tignor GH, Smith AL (1985) Rabies virus binding to cellular membrames measured by enzyme immunoassay. Muscle Nerve 8:336-345

93. Lentz TL, Benson RJJ, Klimowicz D, Wilson PT, Hawrot E (1986) Binding of rabies virus to purified Torpedo acetyllcholine receptor. Mol Brain Res 1:211-219

91. Lentz TL, Wilson PT, Hawrot E, Speicher DW (1984) Amino acid sequence similarity between rabies virus glycoprotein and snake venom curaremimetic neurotoxins. Science 226:847-848

94. Levy NS, Malipiero UV, Lebecque SG, Gearhart PJ (1989) Early onset of somatic mutation in immunoglobulin $\mathrm{V}_{\mathrm{H}}$ genes during the primary immune response.J Exp Med $169: 2007-2019$

95. Lieberman R, Potter M, Humphrey W, Mushinski EB, Vrana M (1975) Multiple individual and cross-specific idiotypes on 13 levan-binding myeloma proteins of $\mathrm{BALB} / \mathrm{C}$ mice. J Exp Med 142:106-119

96. Maddelena A, Hudak S, Claflin JL (1984) Idiotypes of antiphosphorylcholine antibodies: structural correlates. Ann Immunol (Paris) 135C: 117-122

97. Male DK (1986) Idiotypes and autoimmunity. Clin Exp Immunol 65:1-9

98. Manheimer-Lory AJ, Monestier M, Bellon B, Alt FW, Bona CA (1986) Fine specificity, idiotypy, and nature of cloned heavy-chain variable region genes of murine monoclonal rheumatoid factor antibodies. Proc Natl Acad Sci 83:8293-8297

99. Manohar V, Brown E, Leiserson WM, Chused TM (1982) Expression of Lyt-1 by a subset of B lymphocytes. J Immunol 129:532-538

100. Max EE (1984) Immunoglobulins: Molecular genetics, in Fundamental Immunology, WE Paul Ed, Raven Press, New York, pp 167-204

101. Monestier M, Manheimer-Lory A, Bellon B, Painter C, Dang H, Talal N, Zanetti M, Schwartz R, Pisetsky D, Kuppers R, Rose N, Brochier J, Klareskog L, Holmdahl R, Erlanger B, Alt F, Bona C (1987) Shared idiotopes and restricted immunoglobulin variable region heavy chain genes characterize murine autoantibodies of various specificities. J Clin Invest 78:753-759

102. Müller CE, Rajewsky K (1984) Idiotope regulation by isotype switch variants of two monoclonal antiidiotope antibodies. J Exp Med 159:758-772

103. Nahmias C, Cazaubon S, Strosberg AD (1989) A rabbit antiserum detects a VH 5558 subgroup marker highly expressed among anti-alprenolol antibodies. I Immunol $142: 871-876$ 
104. Naparstek $\mathbf{Y}$, Duggan D, Schattner A, Madaio MP, Goni F, Frangione B, Stollar BD, Kabat EA, Schwarta RS (1985) Immunochemical similarities between monoclonal antibacterial. Waldenstrom's macroglobulins and monocional anti-DNA lupus autoantibodies. J Exp Med 161:1525-1533

105. Oudin J, Miehel M (1963) Une nouvelle forme d'allotypie des globulines du serum de lapin apparement liée a la fonction et a la specificité anticorps. C R Acad Sci (Paris) 257:805-808

106. Oudin J, Cazenave P-A (1971) Similar idiotypic specificities in immunoglobulin fractions with different antibody functions or even without detectable antibody function. Proc Nat] Acad Sci 68:2621-2620

107. Paul WE, Bona C (1985) Regulatory idiotopes. Immunol Today 3:230-234

108. Perimutter RM, Kearney JF, Chang SP, Hood LE (1985) Developmentally controlled expression of immunoglobulin $\mathrm{V}_{\mathrm{H}}$ genes. Science $227: 1597-1600$

109. Plater-Zyberk C, Maini RN, Lam K, Kennedy TD, Janossy G (1985) A rheumatoid arthritits $B$ cell subset expresses a phenotype similar to that in chronic lymphocyte leukemia. Arthritis Rheum 28:971-976

110. Plotz PH (1983) Autoantibodies are anti-idiotype antibodies to antiviral antibodies. Lancet oct:824:826

111. Pollok BA, Kearney JF, Vakil M, Perry RP (1984) A biological consequence of variation in the site of $\mathrm{D}-\mathrm{J}_{\mathrm{H}}$ gene rearrangement. Nature $311: 376-379$

112. Rajewsky K, Takemori T (1983) Genetics, expression, and function of idiotypes. Ann Rev immunol 1:569-607

113. Reagan KJ, Wunner WH (1985) Rabies virus interaction with various cell lines is independent of the acetylcholine receptor. Arch Virol 84:277-282

114. Reth M, Kelsoe G, Rajewsky K (1981) Idiotypic regulation by isologous monoclonal anti-idiotope antibodies. Nature 290:257-259

115. Review of the notation for the allotypic and related markers of human immunoglobulins (1976) J Immunol 117:1056-1058

116. Robbins PF, Rosen EM, Haba S, Nisonoff A (1986) Relationship of VH and V genes encoding three idiotypic families of anti-p-azobenzenearsonate. Proc Natl Acad Sci $83: 1050-1054$

117. Roilt IM, Thanavala YM, Malle DK, Hay FC (1985) Anti-idiotypes as surrogate antigens: structural considerations. Immunol Today 6:265-267

118. Rubinstein LJ, Yeh M, Bona CA (1982) Idiotype-anti-idiotype network. II. Activation of silent clones by treatment at birth with idiotypes is associated with the expansion of idiotype-specific helper T cells. J Exp Med 156:506-521

119. Sacks DL. Kelsoe GH, Sachs DH (1983) Induction of immune responses with anti-idiotypic antibodies: implications for the induction of protective immunity. Springer Sem Immunopathol 6:79-97

120. Schreiber AL, Couraud PO, Andre C, Vray B, Strosberg AD (1980) Anti-alprenolol anti-idiotypic antibodies bind to beta-adrenergic receptors and modulate catecholaminesensitive adenylate cyclase. Proc Natl Acad Sci 77:7385-7389

121. Schwartz M, Novick D, Givol D, Fuchs S (1978) Induction of anti-idiotypic antibodies by immunisation with syngeneic spleen cells educated with acetylcholine receptor. Nature 273:543-545 
122. Sege K, Peterson PA (1978) Use of antidiotypic antibodies as cell-surface receptor probes. Proc Natl Acad Sci 75:2443-2447

123. Shechter $\mathbf{Y}$, Maron R, Elias D, Cohen IR (1982) Autoantibodies to insulin receptor spontaneously develop as anti-idjotypes in mice immunized with insulin. Science 21 6:542-545

124. Sheppard HW, Gutman GA (1981) Allelic forms of rat $k$ chain genes; Evidence for strong selection at the level of nucleotide sequence. Proc Natl Acad Sci 78:7064-7068

125. Shoenfeld $\mathbf{Y}$, Ben-Yehuda $\mathbf{O}$, Messinger $\mathbf{Y}$, Bentwitch $Z$, Rauch J, Isenberg DI, Gadoth Gadoth N (1988) Autoimmune diseases other than lupus share common anti-DNA idiotypes. Immunol Lett 17:285-290

126. Siegelman M, Capra JD (1981) Complete amino acid sequence of light chain variable regions derived from five monoclonal anti-p-azophenyl arsonate antibodies differing with respect to a crossreactive idiotype. Proc Natl Acad Sci 78:7679-7683

127. Sigal N, Pickard AR, Metcalf ES, Gearhart PJ, Klinman N (1977) Expression of phosphorylcholine-specific B cells during murine development. J Exp Med 146:933-948

128. Sigal NH, Klinman NR (1978) The B-cell clonotype repertoire. Adv Immunol 26:255337

129. Silverstein AM (1984) The history of immunology. In: Fundamental Immunology, WE Paul Ed, Raven Press, New York pp. 23-40

130. Soderstrom T, Hansson G, Larson G (1984) The Escherichiae coli K1 capsule shares antigenic determinants with the human gangliosides GM3 and GD3. N Engl $\mathrm{J}$ Med 310:726-7

131. Souroujon MC, Fuchs S (1985) Idiotypes and anti-idiotypes in experimental autoimmune myasthenia gravis. Ann N Y Acad Sci 475:81-93

132. Souroujon MC, Pachner AR, Fuchs S (1986) The treatment of passively transferred experimental myasthenia with anti-idiotypic antibodies. Neurol 36:622-625

133. Stefansson K, Dieperink ME, Richman DP, Gomez CM, Marton LS (1985) Sharing of antigenic determinants between the nicotinic acetylcholine receptor and proteins in Escherichiae coli, Proteus vulgaris, and Klebsiella pneumoniae. N Engl J Med 312:221225

134. Stefansson K, Dieperink ME, Richman DP, Marton LS (1987) Sharing of epitopes by bacteria and the nicotinic acetylcholine receptor: a possible role in the pathogenesis of myasthenia gravis. Proc Natl Acad Sci 505:451-460

135. Stein KE, Soderstrom T (1984) Neonatal administration of idiotype or anti-idiotype primes for protection against Escherichia coli $\mathrm{K} 13$ infection in mice. I Exp Med 160:1001-1011

136. Strayer DS, Cosenza H, Lee WMF, Rowley DA, Köhler H (1974) Neonatal tolerance induced by antibody against antigen-specific receptor. Science 186:640-642

137. Takemori T, Rajewsky K (1984) Specificity, duration and mechanism of idiotype suppression induced by neonatal injection of monoclonal anti-idiotope antibodies into mice. Eur J Immuno\ 14:656-667

138. Takemori T, Rajewsky K (1984) Mechanism of neonatally induced idiotype suppression and its relevance for the acquisition of self-tolerance. Immunol Rev 79:103-117 
139. Tzartos SJ, Lindstrom JM (1980) Monoclonal antibodies used to probe acerylcholine receptor structure Localization of the main immunogenic region and detection of similaritites between subunits. Proc Natl Acad Sci 77:755-759

140. Tzartos SJ, Rand DE, Einarson BL, Lindstrom JM (1981) Mapping of surface s.tructures on Electrophorus acetylcholine receptor using monoclonal antibodies. J Biol Chem 256:8635-8645

141. Tzartos S, Langeberg L, Hochschwender S, Lindstrom J (1983) Demonstration of a main immunogenic region on acetylcholine receptors from human muscle using monoclonal antibodies to human receptor. FEBS Lett 158:116-118

142. Urbain J, Wuilmart C (1982) Some thoughts on idiotypic networks and immunoregulation. Immunol Today 3:88-92

143. Urbain J, Slaoui M, Mariamé, Leo O (1984) Idiotypes and intemal images. In: Idiotypy in biology and medicine, H Kohler, J Urbain, P-A Cazenave Eds, Academic Press Inc, Orlando pp. 17

144. Vakill M, Kearney JF (1986) Functional characterization of monoclonal auto-anti-idiotype antibodies isolated from the earlly $B$ cell repertoire of BALB/c mice. Eur J Immunol $16: 1151-1158$

145. Vakil M, Sauter H, Paige C, Kearnet JF (1986) In vivo suppression of perinatal multispecific B cells results in a distortion of the adult B cell repertoire. Eur J Immunol 16:1159-1165

146. Vakil M, Kearney JF (1988) Regulatory influences of neonatal multispecific antibodies on the developing B cell repertoire. Intern Rev Immunol 3:117-131

147. Valderrama R, Eggers AE, Moomiy M, Kao PN, Michl J (1988) Treatment of experimental myasthenia with autologous idiotypes linked to muramyl dipeptide. Clin Exp Immunol 73:123 127

148. Victor-Kobrin C, Manser T, Moran TM, Imanishi-Kari T, Gefter M, Bona CA (1985) Shared idiotopes among antibodies encoded by heavy-chain variable (VH) gen members of the $\mathrm{J558} \mathrm{VH}_{\mathrm{H}}$ family as basis for cross-reactive regulation of clones with different antigen specificity. Proc Natl Acad Sci 82:7696-7700

149. Vincent A, Whiting PJ, Schluep M, Heidenreich F, Lang B, Roberts A, Willcox N, Newsom-Davis J (1987) Antibody heterogeneity and specificity in myasthenia gravis. Ann N Y Acad Sci 505:106-120

150. Wasserman NH, Penn AS, Freimuth PI, Treptow N, Wentzel S, Cleveland WL, Erlanger BF (1982) Anti-idiotypic route to anti-acetylcholine receptor antibodies and experimental myasthenia gravis. Proc Nall Acad Sci 79:4810-4814

151. Wikler M, Franssen J-D, Collignon C, Leo O, Mariamé B, van de Walle P, De Groote D, Urbain $\mathbf{J}(1979)$ Idiotypic regulation of the immune system. Common idiotypic specificities between idiotypes and antibodies raised against anti-idiotypic antibodies in rabbits. J Exp Med 150:184-195

152. Wood JN, Hudson L, Jessell TM, Yamamoto M (1982) A monoclonal antibody defining antigenic determinants on subpopulations of mammalian neurons and Trypanosoma cruzi parasites. Nature 296:34-38

153. Wu TT, Kabat EA (1970) An analysis of the sequences of the variable regions of Bence Jones proteins and myeloma light chains and their implications for antibody complementarity. J Exp Med 132:211-240 
154. Yancopoulos GD, Desiderio SV, Paskind M, Kearney JF, Baltimore D, AIt FW (1984) Prefenential utilization of the most $J_{H}$ proximal $V_{H}$ gene segments in pre-B-cell lines. Nature 311:727-733

155. Zanetti M, Bigazzi PE (1981) Anti-idiotypic immunity and autoimmunity. I. In witro and in vivo effects of anti-idiotypic antibodies to spontaneously occuring autoantibodies to rat thyroglobulin. Eur J Immunol 11:187-195

156. Zanetti M (1985) The idiotype network in autoimmune processes. Immunol Today $6: 299-302$

157. Zanetti M, Katz DH (1985) Self-recognition, auto-immunity, and internal images. Current Topics in Microbiol Immunol 119:111-126

158. Zanetti M (1986) New concepts in autoimmunity. Immunol Invest 15:287-310

159. Zanetti M, Glotz D, Rogers J (1986) Pertubation of the autoimmune network. II. Immunization with isologous idiotype induces auto-anti-idiotypic antibodies and suppresses the autoantibody response elicited by antigen: a serologic and cellular analysis. J Immunol 137:3140-3146

160. Zanetti M, Rogers J (1987) Independent expression of a regulatory idiotype on heavy and light chains. J Immunol 139:1965-1970 


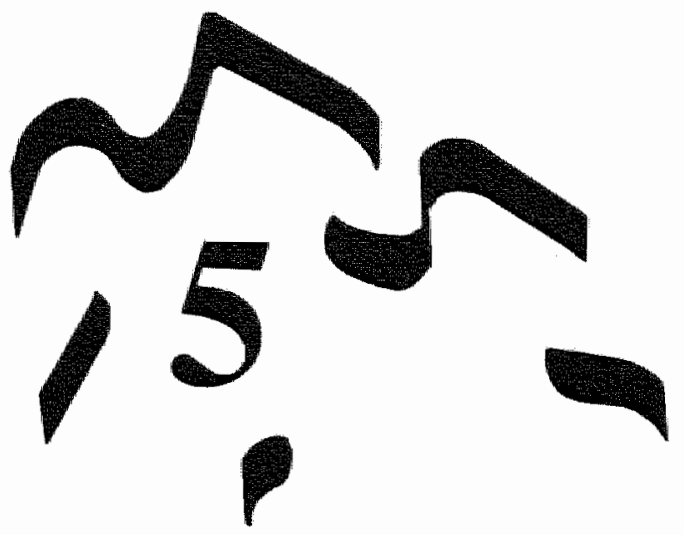

\section{PAKATOPE AND FRAMEWORK RELATED CROSSREACTIVE IDIOTOPES ON ANTI-ACETYLCHOLINE RECEPTOR ANTIBODIES}

Jan J.G.M. Verschuuren, Yvo M.F. Graus, Nicolaas A. Bos, Socrates J. Tzartos, Peter J.C. van Breda Vriesman, Marc H. De Baets 


\section{Introduction}

Experimental autoimmune myasthenia gravis (EAMG) mirrors human myasthenia gravis (MG). Both diseases are characterized by abnormal muscular weakness and increased fatiguebility of voluntary muscles, caused by an antibody mediated immune response to the nicotinic acetylcholine receptor $(\mathrm{AChR})(21)$. The antibody dependence of EAMG and MG is demonstrated by the effectiveness of passive transfer of the disease by means of antibodies $(36,37)$ and by the benificial effects of plasmapheresis $(7,27)$. These antibodies play a central role in the pathogenesis, and therefore insights into the regulation of production of these autoantibodies could be of interest for specific immunosuppressive treatment.

One theory concerning the regulation of antibody production is Jerne's network theory. According to this network theory, the immune system can be seen as a web of variable regions domains in which the connection between clones is based on idiotype-antiidiotype interactions. Idiotypes (Id) can be defined as the collection of antigenic determinants, i.e. idiotopes (Id), associated with the variable region of an antibody. Anti-idiotypes (anti-Id) are antibodies with an antigen combining site recognizing an idiotope. The balance between clones as well as the various subsets of cells that regulate their expression can therefore be influenced by antigen, idiotypes and anti-idiotypes (12). Id-anti-Id interactions may play an important regulatory role. One of the requirements for a putative regulatory idiotype is the expression of crossreacting idiotopes (CRI) (3).

Whether or not CRI's are present in MG is a topic of debate, since the idiotype sharing in MG observed in two studies $(9,38)$ was refuted in another (48). Also, in EAMG some groups reported the presence of CRI's $(5,40,46)$, but others failed to find any crossreactivity $(34,44)$. To date, only two groups have reported on CRI's in the rat. One study showed negative results (13), the other was succesful in finding paratope related CRI's (18). Neither one of them reported on framework CRI's. Hence, there is no consensus regarding the existence of CRI's on anti-AChR antibodies.

We have performed an idiotypic analysis of 3 anti-AChR monoclonal antibodies $(\mathrm{mAb})$, directed against the extracellular located main immunogenic region (MIR) on the AChR, 2 anti-AChR mAb's recognizing intracellular determinants of the $A C h R$ and 2 control myeloma proteins. The idiotype profile of the anti-MIR mAb's is particularly pertinent, because these mAb's are capable of indacing EAMG, and about $50 \%$ of the anti-AChR antibodies in both MG and EAMG is thought to be directed to the MIR of the AChR $(19,33)$.

We were able to identify CRI's associated with the antigen binding site, i.e. the paratope, of these anti-MIR anti-AChR mAb's, as well as non-paratope related "framework" CRI's on all 5 anti-AChR mAb's. 


\section{Material and methods}

\section{Monoclonal antibodies}

Hybridoma's secreting anti acetylcholine receptor ( $\mathrm{AChR}) \mathrm{mAb6}\left(\mathrm{IgG}_{1}\right.$, Lewis), mAb35 (IgG 1 ,Sprague-Dawley), mAb61 (IgG2^, Lewis), mAb65 (IgG1, Louvain), mAb155 (IgG2a, Lewis) (kindly donated by Dr. S. Tzartos, Institute Pasteur Hellenique, Athens, Greece) were all produced in rats $(9,20,38)$. MAb's 6, 35, and 65 are directed at the main immunogenic region (MIR), residing on the extracellular site of the $\alpha$-subunit of the AChR. MAb's 61 and 155 recognize intracellular epitopes. Hybridoma D6 ( $\operatorname{IgG}_{2 \mathrm{a}}, \mathrm{BALB} / \mathrm{c}$ ) (kind gift from Dr. A. Vincent, John Radcliffe Hospital, Oxford, England) is probably directed at the equivalent of the MIR on the human AChR (48). Myeloma proteins IR27 and IR241 (both IgG 1 , Louvain) (kind gift from Dr. H. Bazin, Institute Pasteur, Brussels) were used as control rat mAb's. MAb's were purified by ion exchange HPLC and conjugates to horse-radish peroxidase (HRP) were prepared (mAb-HRP). MAb PM2, PM5, PM6 (mouse IgG1, BALB/c) (kind gift of Dept. of Pathology, Dr. C. Verstijnen, University of Limburg, Maastricht) are directed at carcinoembryogenic antigen $(45,46), \mathrm{mAb} 1.15,9.1$, 14.14 (mouse $\operatorname{IgG} 1, \mathrm{BALB} / \mathrm{c}$ ) directed at human thyroglobulin, and $\mathrm{mAb} 8$ and 204 (mouse $\mathrm{IgG}_{1}, \mathrm{BALB} / \mathrm{c}$ ) (kind gift of Dept. of Microbiology, Dr. C. Bruggeman, University of Limburg, Maastricht) directed at rat $\mathrm{CMV}$ virus were used as control mouse mAb's (5).

\section{Preparation of $A C h R$}

AChR from the main electric organ of Torpedo californica was purified by affinity chromatography on Naja naja siamensis coupled to CNBr-activated Sepharose-4B, as described in chapter 2 .

\section{Antiidiotypic antibodies}

New Zealand rabbits were immunized with $100-200 \mu \mathrm{g}$ anti-AChR mAb or IR27 in complete Freund's adjuvant (CFA) and subsequently boosted three times with mAb in incomplete Freund adjuvans at two-weekly intervals. Injections were given intradermally at multiple sites on the back. Animals were bled one week after the last booster immunization. The anti-idiotype serum (anti-Id) was absorbed at $4^{\circ} \mathrm{C}$, by Lewis rat $\operatorname{IgG}(5 \mu \mathrm{g} / \mathrm{ml})$ coupled to Sepharose-4B columns ( $10 \mathrm{ml})$. After five to eight absorptions no significant binding to polyclonal Louvain or Lewis IgG was observed by an indirect anti-id binding ELISA. Next the serum was affinity purified on Sepharose columns, containing the mAb used for immunization. Elution was performed with $1 \mathrm{~N} \mathrm{HCl}$, containing $0.10 \mathrm{M}$ glycine, $0.15 \mathrm{M} \mathrm{NaCl}, \mathrm{pH} 2.8$. After dialysis against PBS the eluate was used for in vitro assays. 
After absorption anti-Id's were tested for specificity by indirect anti-Id binding ELISA. Polywinyl 96-well microtiter plates (Greiner, Alphen a/d Rijn, The Netherlands) were coated with $50 \mu$ anti-AChR $\mathrm{mAb}$, polyclonal Lewis or Louvain rat IgG $(5 \mu \mathrm{g} / \mathrm{ml})$ for $1 \mathrm{hr}$ at $37^{\circ} \mathrm{C}$. After washing three times with $\mathrm{H}_{2} \mathrm{O}$, containing $0.5 \%$ Tween $\left(\mathrm{H}_{2} \mathrm{O}-\mathrm{Tw}\right)$, plates were incubated with PBS containing $0.5 \%$ bovine serum albumen and $0.5 \%$ Tween-20 (Serva/Brunschwig chemie bv, Amsterdam, The Netherlands) (PBSA-Tw) for 30 minutes at room temperature. Serial dilutions (1/10-1/10000) of anti-Id were allowed to incubate for $1 \mathrm{hr}$ at room temperature on a rocker. After washing again with $\mathrm{H}_{2} \mathrm{O}-\mathrm{T}$ w the wells were incubated with $50 \mu \mathrm{l}$ of goat-anti-rabbit IgG (Miles/Bayer, Mijdrecht, The Netheriands) coupled to horse radish peroxidase (HRP) for $1 \mathrm{hr}$ at room temperature on a rocking platform. After washing again with $\mathrm{H}_{2} \mathrm{O}$-Tw the colorimetric reaction was developed by adding 100 $\mu l$ of $1.1 \mathrm{M} \mathrm{Na}$-acetate-buffer, $\mathrm{pH} 5.5$, containing tetramethylbenzidine (TMB) (10 $\mathrm{mg} / \mathrm{ml}$ ) and $0.01 \% \mathrm{H}_{2} \mathrm{O}_{2}$. After 10 minutes the reaction was stopped by adding 50 $\mu \mathrm{l} 4 \mathrm{~N} \mathrm{H}_{2} \mathrm{SO}_{4}$. Reading was done at $450 \mathrm{~nm}$ (Titertek Twinreader, Amstelstad, Amsterdam, The Netherlands).

\section{Crossreactive idiotype assays}

a) Direct binding of mAb-HRP to anti-Id's was performed using a direct Id binding ELISA. Polyvinyl 96-well microtiter plates were coated with $50 \mu$ of affinity purified anti-Id or monoclonal anti-Id $(5 \mu \mathrm{g} / \mathrm{ml})$ for $1 \mathrm{hr}$ at $37^{\circ} \mathrm{C}$. After washing 3 times with $\mathrm{H}_{2} \mathrm{O}-\mathrm{Tw}$, plates were incubated with PBSA-Tw for 30 minutes at room temperature. Then $50 \mu \mathrm{l}$ of increasing amounts $(0.03-15 \mu \mathrm{g} / \mathrm{ml})$ of HPLC purified $\mathrm{mAb}$ 's, conjugated to HRP, were allowed to incubate for $1 \mathrm{hr}$ at room temperature on a rocker. The last part of the ELISA was performed as described above.

b) Crossreacting Id's were also sought using a competitive Id binding ELISA. The inhibition of the binding of mAb to anti-Id was investigated, as described above, with little adjustments. Briefly, increasing amounts $(0.003-10 \mu \mathrm{g} / \mathrm{ml})$ of non-conjugated inhibiting $\mathrm{mAb}$ 's were alowed to incubate overnight on anti-Id coated wells $(5 \mu \mathrm{g} / \mathrm{mll})$. Then, $50 \mu \mathrm{l}$ of previously determined limiting amounts of HRP-labeled $\mathrm{mAb}$ 's (range $1-16 \mu \mathrm{g} / \mathrm{ml}$ ) were added without washing for $1 \mathrm{hr}$, and the bound HRP activity was measured as mentioned above. The percent inhibition was calculated as follows:

[Average $\mathrm{A}_{450}$ of duplicate wells with conjugated m.Ab alone]-[Average A450 of duplicate wells in which conjugated $\mathrm{mAb}$ were tested in presence of putative inhibitor]/[Average $A_{450}$ of eigth wells with conjugated mAb alone] $] 100$

Values were expressed as the concentration needed for $50 \%$ inhibition ( 150 ).

c) Id-anti-Id binding specificity was investigated by inhibition ELISA using Torpedo-AChR as inhibitor. The assay was similar to the competitive Id binding ELISA. 
Briefly, anti-Id was immobilized on microtiter wells as described above. HRPlabeled Id was preincubated with Torpedo-AChR (previously dialysed against PBSA-Tw to remove cholic acid) at $0.002-50 \mu \mathrm{g} / \mathrm{ml}$ for 2 hours at $4{ }^{\circ} \mathrm{C}$. The mixtures were allowed to incubate for 1 hour. Thereafter plates were washed and the colorimetric reaction developed, as described above.

d) Crossreactive Id's (CRI's) on mouse mAb's were analysed by an indirect anti-Id binding ELISA. Polyvinyl 96-well microtiter plates were coated with $50 \mu \mathrm{lmAb}$ ( 5 $\mu \mathrm{g} / \mathrm{ml}$ ) for 1 hour at $37^{\circ} \mathrm{C}$. After washing 3 times with $\mathrm{H}_{2} \mathrm{O}-\mathrm{Tw}$, plates were then incubated with PBSA-Tw for 30 minutes at room temperature. Then $50 \mu \mathrm{l}$ of affinity purified anti-Id $(2.5 \mu \mathrm{g} / \mathrm{ml})$ was added and allowed to incubate for 1 hour at room temperature on a rocker. After washing $50 \mu$ goat-anti-rabbit-HRP was added and allowed to incubate for 1 hour at room temperature on a rocker. Plates were washed and the colorimetric reaction was developed, as described above.

\section{Paratope-related idiotype assay}

Paratope-related CRI's were analysed by a solid phase antigen binding inhibition RIA. Polyvinyl 96-wells microtiter plates (Flow laboratories Ltd / Amstelstad bv, The Netherlands) were coated with $50 \mu \mathrm{l}$ anti-AChR mAb's or affinity purified EAMG serum antibodies $(5 \mu \mathrm{g} / \mathrm{ml})$ for $1 \mathrm{hr}$ at $37^{\circ} \mathrm{C}$. After washing 3 times with $\mathrm{H}_{2} \mathrm{O}-\mathrm{Tw}$, the plates were then incubated with PBSA-Tw for 30 minutes at room temperature. Then increasing amounts $(0.08-20 \mu \mathrm{g} / \mathrm{ml})$ of affinity purified anti-Id were incubated overnight. Next, previously determined limiting amounts of Torpedo-AChR, labeled with ${ }^{125} \mathrm{I}-\alpha-\mathrm{B}$-Bungarotoxin $\left({ }^{125} \mathrm{I}-\alpha-\mathrm{BT}\right)$, were added for four hours at room temperature. After washing with PBS, containing $0.5 \%$ TRITON $\mathrm{X}-100$ (Sigma / Brunschwig chemie bv, Amsterdam, The Netherlands), and $0.02 \%$ $\mathrm{NaN}_{3}$ the radioactivity bound to the wells was counted in a gamma counter (Compugamma, Pharmacia LKB, Woerden, The Netherlands). The percentage inhibiton was calculated as follows:

[Average cpm of duplicate wells with Torpedo-AChR- ${ }^{125} \mathrm{I}-\alpha-\mathrm{BT}$ alone] - [Average cpm of duplicate wells in which Torpedo-AChR- ${ }^{125}{ }_{1-\alpha-B T}$ were tested in presence of putative inhibitor]/[Average cpm of duplicate wells with Torpedo-AChR- ${ }^{125} \mathrm{I}-\alpha-\mathrm{BT}$ alonel $\mathrm{x} 100$

Values were expressed as the concentration needed for $50 \%$ inhibition (150).

\section{Affinity purification of anti-AChR antibodies}

Serum of 6-8 rats $(1 \mathrm{ml} / \mathrm{rat})$, obtained 6 weeks after immunization with Torpedo AChR, was pooled. Serum IgG was precipitated by adding an equal volume of saturated ammonium sulfate. After dialysis against PBS this preparation was affinity purified, by overnight absorption at $4^{\circ} \mathrm{C}$, on $1 \mathrm{mg} / \mathrm{ml}$ Torpedo $\mathrm{AChR}$ coupled 
Sepharose $4 \mathrm{~B}$ columns. Elution was performed with glycine- $\mathrm{HCl}, \mathrm{pH} 2.8$, containing $0.9 \% \mathrm{NaCl}$. After dialysis against PBS the eluate was used for an indirect anti-Id binding ELISA, similar to the assay used for the detection of CRI on mouse mAb"s, as described above, whereby the affinity purified anti-AChR IgG was coated (5 $\mu \mathrm{g} / \mathrm{ml})$ on microtiter wells.

\section{$V_{H}$ gene family analysis}

This analysis was performed as described previously (4) using 9 mouse cDNA probes, specific for $V_{H}$ gene families 3609 (probe $V_{H}$ 23-9), J558 (probe VNPB4), S107 (probe 38C), J606 (probe pBV14), 36-60 (probe p6.3RI), X24 (probe X24), Q52 (probe $V_{H}$ Q52), PC7183 ( $V_{H}$ 81X), and VGAM3.8 (probe VGAM3.8).

\section{Production of monoclonal anti-Id}

BALB/c mice (Charles River Wiga GmbH, Frankfurt, FRG) received subcutaneous injections of $\mathrm{mAb} 65(50 \mu \mathrm{g})$ in PBS in an equal volume of CFA in hind foot pads and at the base of the tail. Six booster injections at 3-day interval were given (19), the first boost in Freund's incomplete adjuvant and subsequent boosts were in PBS. Cells for fusion were obtained from draining inguinal and para aortal lymph nodes, 3 days after the last injection. Lymph node cells were fused to the mouse tumor cell line SP2/0-Ag14 (33) according to Köhler and Milstein (14). Tumor cells $\left(1 \times 10^{7}\right)$ are mixed with lymph node cells $\left(2 \times 10^{7}\right)$ in Dulbecco's Modified Egles Medium (DMEM) (GIBCO, Breda, The Netherlands), containing penicilline $(50 \mathrm{IU} / \mathrm{ml})$ and streptomycine $(50 \mu \mathrm{g} / \mathrm{ml}), 2 \mathrm{mM} \mathrm{L}$-glutamine, $1 \mathrm{mM}$ pyruvate, $0.045 \mathrm{M} \mathrm{NaHCO}_{3}$, $\mathrm{pH}$ 7.3. The cells are centrifuged and the supernatant discarded. One $\mathrm{ml}$ of $40 \%$ polyethyleneglycol 4000 ( $0.4 \mathrm{~g}$ with $0.6 \mathrm{ml}$ aqua bidest) is dropwise added over 1 minute, while the tube is gently agitated in a $37^{\circ} \mathrm{C}$ water bath. Thereafter DMEM is added, cells are centrifuged, and the pellet is resuspended in $20 \mathrm{ml} \mathrm{HAT}$ medium, consisting of DMEM with $0.2 \mathrm{mM}$ hypoxanthine, $0.32 \mathrm{mM}$ desoxythymidine, 0.4 $\mu \mathrm{M}$ aminopterine, $15 \%$ fetal calf serum, $1 \%$ hybridoma growth factor containing medium (kind gift from Dr. L. van der Aarden, Centraal Laboratorium voor de Bloedtransfusiedienst, Amsterdam). HAT medium with cells is dispended in 96wells microtiter plates (Costar, Cambridge, USA) at $100 \mu \mathrm{l}$ per well. Next day 100 $\mu l$ of HAT medium is added, and at day 4 half the medium in each well is replaced with fresh medium. Supernatants were screened for anti-Id 65 activity, positive clones are selected, and gradually the HAT medium is replaced by HT medium (HAT medium without hypoxanthine and desoxythymidine), and subsequently by DMEM with $10 \%$ fetal calf serum. Positive clones are subcloned, and cells were stored in medium consisting of 50\% DMEM, $40 \%$ fetal calf serum and $10 \%$ dimethylsulphoxide at $-196^{\circ} \mathrm{C}$ in liquid nitrogen for future use. 


\section{Screening assay for monoclonal anti-ld}

Supernatants were screened for monoclonal anti-Id 65 antibodies by an indirect anti-Id binding ELISA, similar as described above for polyclonal rabbit anci-Id's. Briefly, 96-well microtiter plated were coated with $50 \mu \mathrm{ll}$ Fab2 $\mathrm{mAb} 65(1 \mu \mathrm{g} / \mathrm{ml})$. After washing with $\mathrm{H}_{2} \mathrm{O}$-Tw and preincubation with PBSA-Tw, supernatants were incubated overnight. After washing again with $\mathrm{H}_{2} \mathrm{O}-\mathrm{T}$ w the wells were incubated with $50 \mu \mathrm{J}$ rabbit-anti-mouse IgG (DAKO, Sante Barbera, USA) coupled to HRP for 1 hour at room temperature on a rocker, and bound HRP activity was measured as described above.

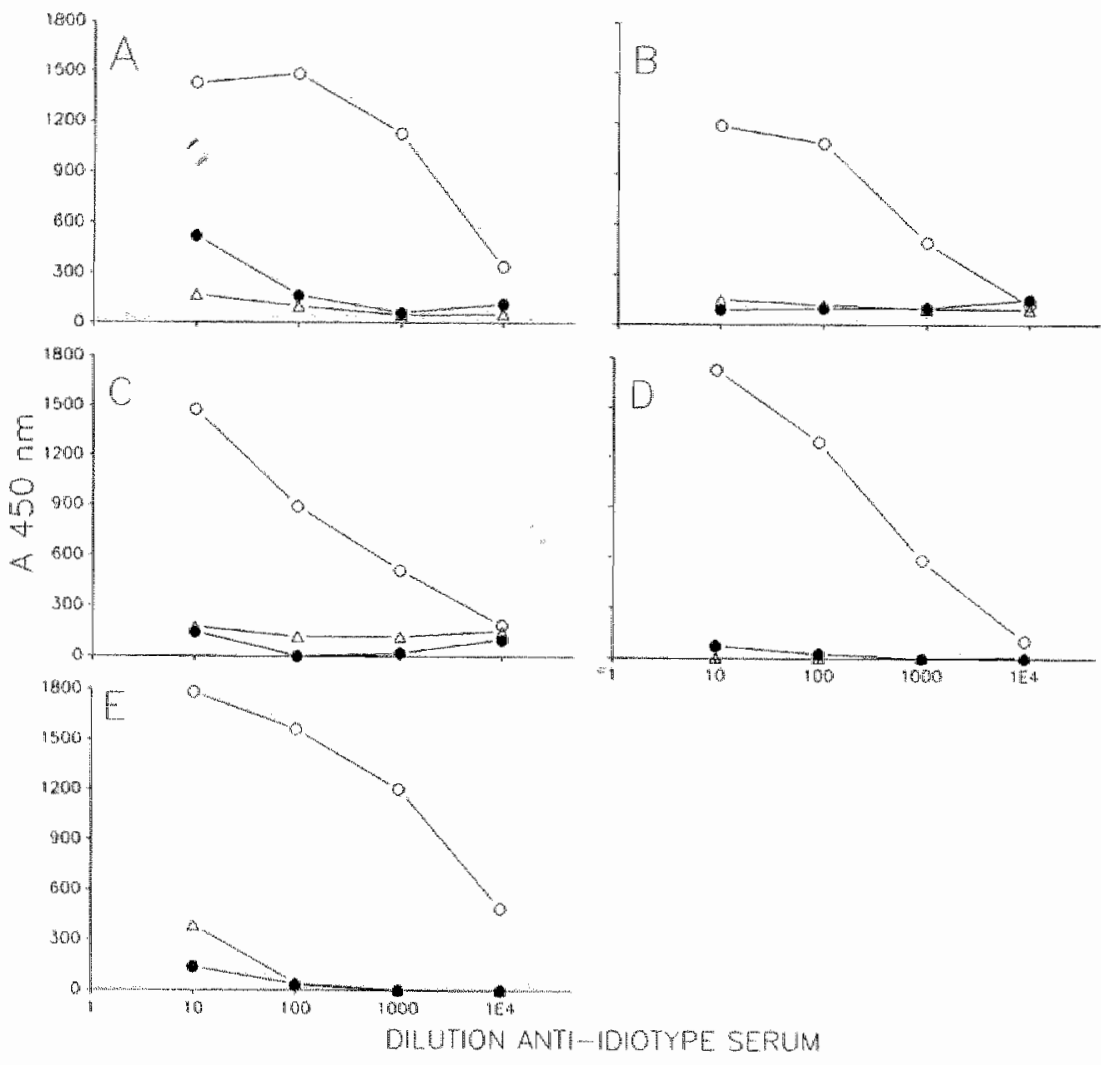

FIGURE 5.1 Absorbed anti-Id sera do not crossreact with polyclonal Lewis or Louvain IgG. Anti-Id sera were tested by an indirect anti-Id binding ELISA. After absorption by polyclonal Lewis or Lowvain IgG, the anti-Id sera bound well to the homologous Id lopen circles), but not to Lewis IgG (filled circles) or Louvain IgG (open triangles). A: anti-Id 6, B: anti-Id 35, C: anti-Id 61, D: anti-Id 65, E: anti-Id IR27 


\section{Results}

\section{Characteristics of anti-Id sera}

Anti-Id's were produced in rabbits for the analysis of the Id on $\mathrm{mAb} 6,35,61,65$ and 155. After extensive absorptions on rat IgG rabbit anti-Id sera were able to bind homologous $\mathrm{mAb}$, but not Lewis or Louvain IgG in an indirect anti-Id binding ELISA (Fig 5.1).

Each anti-Id, raised against a given anti-AChR $m A b$, bound to all five anti-AChR mAb's tested, whereby the amount of homologous Id needed to reach a given absorption in the ELISA was always about 16 times less than the required amount of heterologous Id. Control myeloma proteins IR27 or IR241 were not recognized. Anti-Id IR27 only bound to IR27 and IR241, but not to any of the anti-AChR mAb's. Therefore, CRI's were shared among all 5 anti-AChR mAb's, but not with the control myeloma proteins (Fig 5.2).

\section{Analysis of paratope related crossreactive idiotopes}

Next, we determined whether the idiotypic determinants were associated with the antigen combining site. The binding of mAb 65 to Torpedo AChR could be inhibited by anti-Id $65\left(I_{50}=0.08 \mu \mathrm{g} / \mathrm{ml}\right)$, and also by anti-Id 6 and anti-Id 35 (I50= 14 , respectively $5 \mu \mathrm{g} / \mathrm{ml})$. The anti-Id directed against an anti-AChR mAb (mAb 61), recognizing an intracellular epitope clearly distinct from the MIR, did not show any inhibition. Also, addition of increasing doses of control anti-Id IR27 or NRIgG did not result in any inhibition (Fig 5.3a).

The binding of other anti-AChR mAb's (mAb 6,35,61 and 155) to Torpedo-AChR could only be inhibited by the homologous anti-Id. In Fig 5.3b a typical antigen binding inhibition curve is shown for mAb 35, the results of the other anti-Id's are summarized in Table 5.1. Concentrations needed for $50 \%$ inhibition (I50) varied from 0.06 to $0.36 \mu \mathrm{g} / \mathrm{ml}$. The binding of all anti- $A C h R$ mAb's was not inhibited by anti-Id IR27 or normal rabbit IgG. Non-labeled Torpedo-AChR was always inhibitory.

Thus, sharing of paratope related Id's was found between anti-MIR anti-AChR mAb's (mAb 6, 35, and 65), but not with other anti-AChR mAb's (mAb 61 and 155) or control myeloma proteins. 


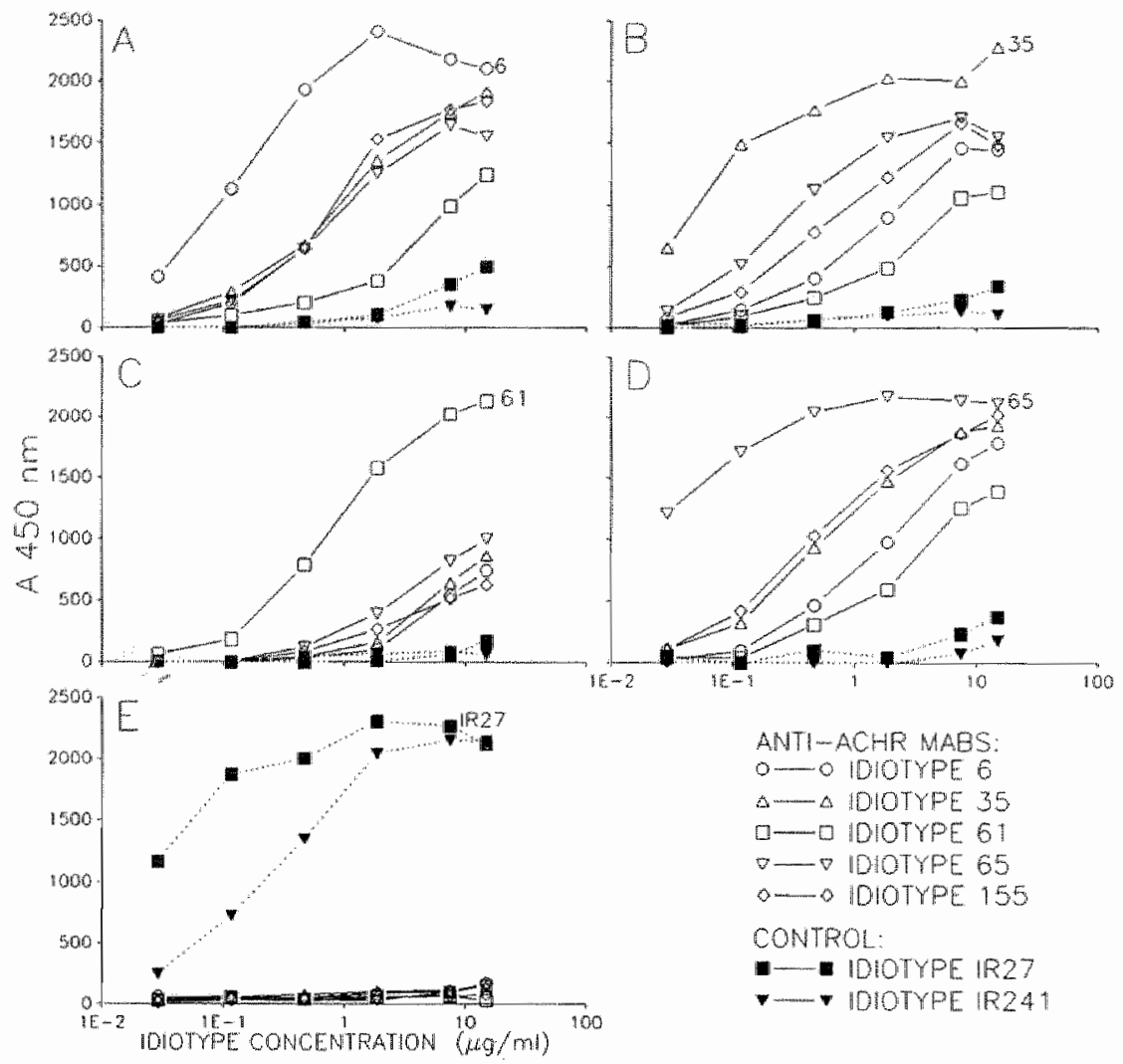

FIGURE 5.2 Affinity purified anti-Id crossreactivity, tested using a direct Id binding ELISA. After absorption the anti-Id's were affinity purified on their corresponding $m A b$ coupled to Sepharose, and tested in a direct Id binding ELISA. Anti-Id's were coated and incubated with anti-AChR MAb's coupled with HRP. Anti-Id's elicited against anti-AChR $m A b^{\prime}$ 's bind all 5 anti-AChR $m A$ 'b's. Control anti-Id IR27 binds only 2 myeloma proteins. A: anti-Id 6, B: anti-Id 35, C: anti-Id 6I, D: anti-Id 65, E: anti-Id IR27

\section{Analysis of framework related crossreactive idiotopes}

In addition, the crossreactions were analysed by competitive inhibition of Id binding, testing the ability of each mAb to inhibit homologous, as well as heterologous, Id-anti-Id interactions. In these assays, both paratope and framework related Id's are detected. It was found that homologous Id-anti-Id bindings could not be inhibited by any $\mathrm{mAb}$ other than the homologous $\mathrm{mAb}$ or Torpedo-AChR. The results shown for anti-Id 6 (Fig 5.4e) are also found for anti-Id 35, anti-Id 61, anti-Id 65, and anti-Id 


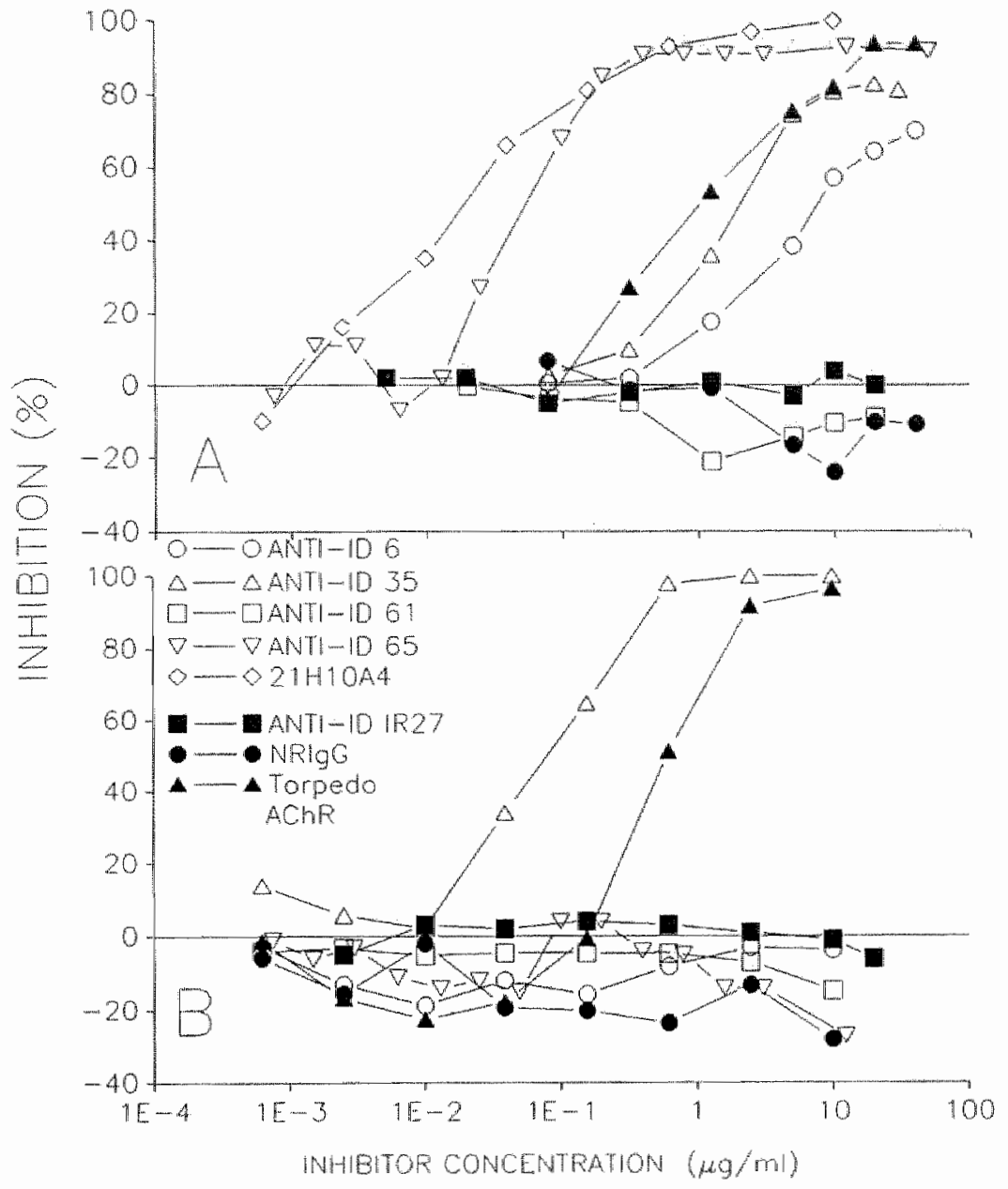

FIGURE 5.3 Anti-MIR antibodies share paratope-related CRI's. Paratope-related CRI's were analysed by a solid phase antigen binding inhibition RIA. Anti-AChR mAb's were coated on a microtiter plate, and incubated with increasing anounts of anti-Id, unlabeled Torpedo $A C h R$, or normal rabbit IgG. Then I25I-BT-Torpedo AChR was added. Binding is expressed as percentage of binding of 125I-BT-Torpedo AChR to the anti-AChR mAb in the presence of buffer. A: Binding of mAb 65 to Torpedo AChR can be inhibited by polyclonal anti-Id 6 , anti-Id 35, anti-Id 65, and monoclonal anti-Id 21H10A4 or Torpedo AChR. B: Binding of mAb 35 to Torpedo AChR can only be inhibited by polyclonal anti-Id 35 or Torpedo AChR. 
Binding Anti-AChR Monoclonal
6
35
61
65
155

Inhibitor

$\begin{array}{llllll}\text { ANTI-ID 6 } & 0.16^{\mathrm{a}} & >>20 & >>10 & 14 & >>20 \\ \text { ANTI-ID 35 } & >>10 & 0.06 & >>10 & 5 & >>20 \\ \text { ANTI-ID 61 } & >>10 & >>20 & 0.36 & >>20 & >>20 \\ \text { ANTI-ID 65 } & >>30 & >>50 & \text { NT } & 0.08 & >>30 \\ \text { ANTI-ID IR27 } & >>20 & >>20 & \text { NT } & >>20 & >>20 \\ \text { NRIgG }^{b} & >>30 & >>50 & >>10 & >>20 & >>30 \\ \text { TORPEDO-ACHR }^{\mathrm{C}} & 1.0 & 0.6 & 1.4 & 0.36 & 0.14\end{array}$

TABLE 5.1 Anti-MIR antibodies share paratope related idiotopes.

Paratope-related CRI's were analysed by a solid phase antigen binding inhibition RIA. Anti-AChR mAb's were coated on a microtiter plate, and incubated with increasing anounts of anti-ld, unlabeled Torpedo AChR, or normal rabbit IgG. Then ${ }^{125}$ I-alpha-BTTorpedo ACkR was incubated, and after washing the radioactivity bound to the wells was counted. Inhibition is expressed as the concentration ( $\mu \mathrm{g} / \mathrm{ml})$ needed for $50 \%$ inhibition of binding of ${ }^{125} /$-alpha-BT-Torpedo AChR to the anti-AChR MAb. In each instance anri-Id blocks the binding of homologous Id and in addition the binding of mab 65 is blocked by anti-ld 6 and anti-Id 35, but not by anti-Id 61 or anti-Id IR2T. NT: not tested. ": Cancentration $(\mu \mathrm{g} / \mathrm{ml})$ for $50 \%$ inhibition. ' Normal rabbit IgG (NRIgG) never showed any blocking. ": Unlabeled Torpedo-AChR was always able to block.

IR27 (Table 5.2). These data appear contradictory to those found in the direct binding assays of all 5 anti-AChR mAb's to each of the anti-AChR anti-Id's (Fig 5.2). For, if non-homologous Id-anti-Id binding were specific, then it would be expected that the binding of a given anti-AChR mAb to a non-homologous anti-Id is inhibitable to some extent by another $\mathrm{mAb}$. Indeed, the heterologous (criss $-\mathrm{cross}$ ) Id-anti-Id binding, employing anti-AChR anti-Id's, could be inhibited by all anti- 


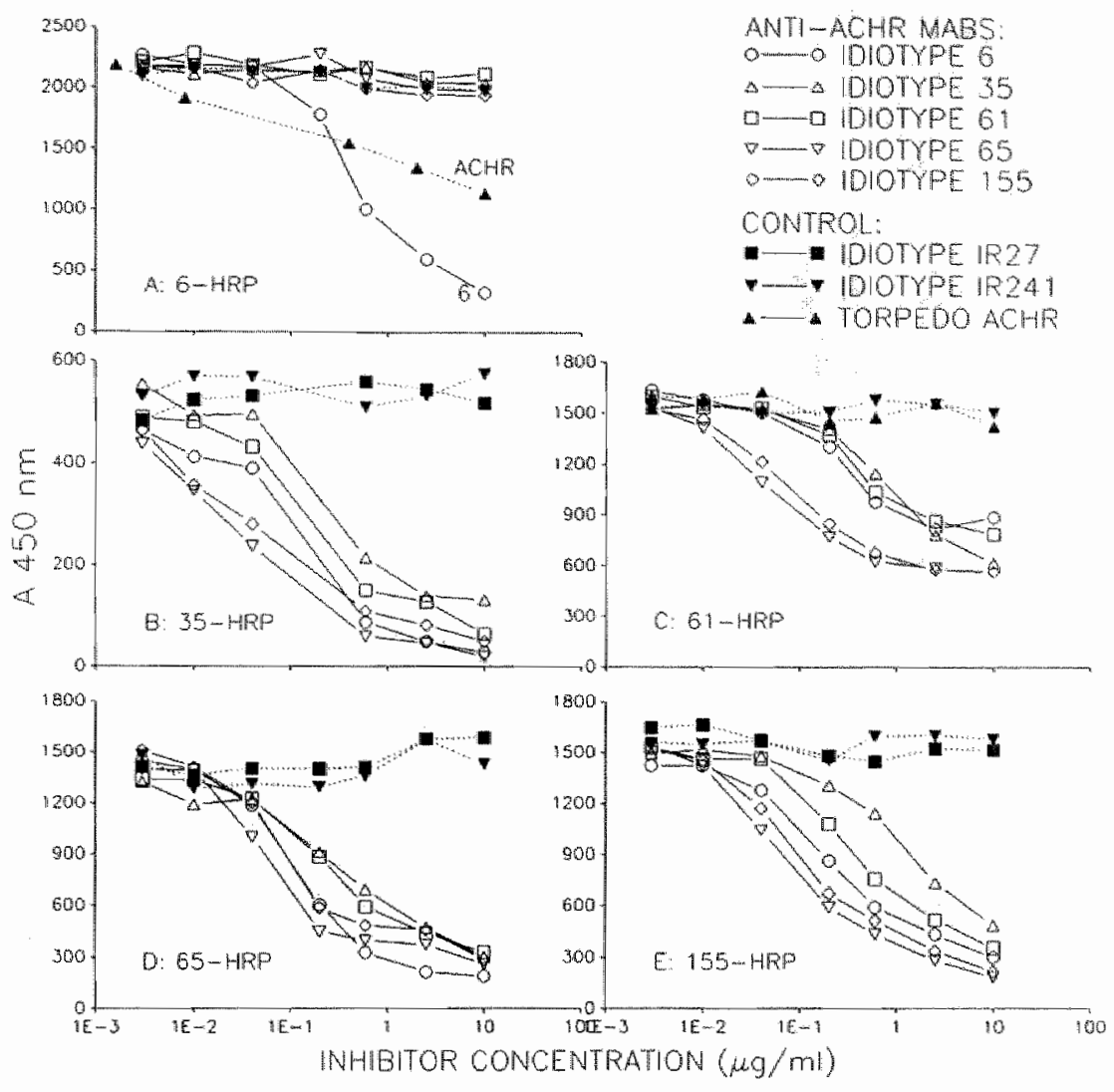

FIGURE 5.4 Framework CRI's on anti-AChR mAb's. Framework CRI's were sought using anti-Id 6 in a competitive Id binding ELISA. Microtiter plated were coated with affinity purified anti-Id 6 , and incubated overnight with increasing amounts of unlabeled anti-AChR $M A b^{\prime}$ s. Then anti-AChR mAb's labeled with HRP were added, as indicated in the left hand corner. A: inhibition of binding of $M A b$ 6-HRP to anti-ld 6, B: inhibition of binding of $M A b 35-H R P$ to anti-Id 6, C: inhibition of binding of mAb 61-HRP to anti-Id 6, D: inhibition of binding of MAb 65-HRP to anti-Id 6, E: inhibition of binding of MAb 155-HRP to anti-Id 6.

AChR mAb's, but not by mAb IR241 or IR27 (Fig 5.4a,b,c,d). Binding of anti-Id IR27 to mAb IR27 or IR241 could not be inhibited by any of the anti-AChR mAb's nor by Torpedo AChR (Table 5.2). 


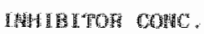
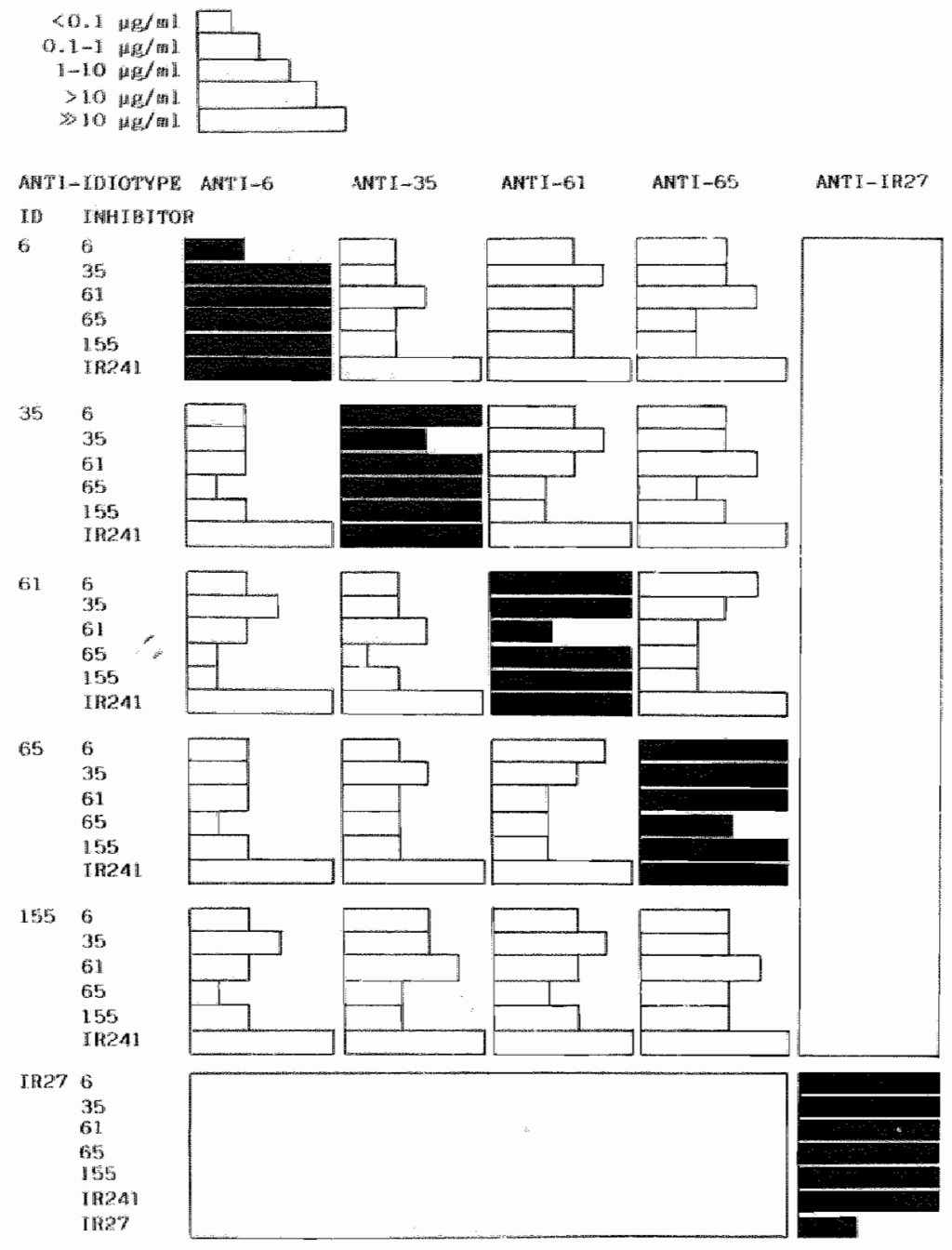

TABLE 5.2 Results of homologous and heterologous anti-Id crossreactivity. CRI's were sought using a competitive Id binding ELISA. Coated anti-Id's are indicated at the top of each column. HRP labeled Id used for binding is indicated at the most left hand column. Id's tested for inhibition at increasing amounts $(0.03-10 \mu \mathrm{g} / \mathrm{ml})$ are indicated at the second left hand column. Values, indicated as horizontal bars, are concentrations needed for $50 \%$ inhibition, as indicated at the top of the table: the highest dosis which was tested was $10 \mu \mathrm{g} / \mathrm{ml}$, " $>$ "indicates that at this concentration the inhibition was less than $50 \%$, ">" indicates that no inhibition was seen. Results of homologous Id-anti-Id 


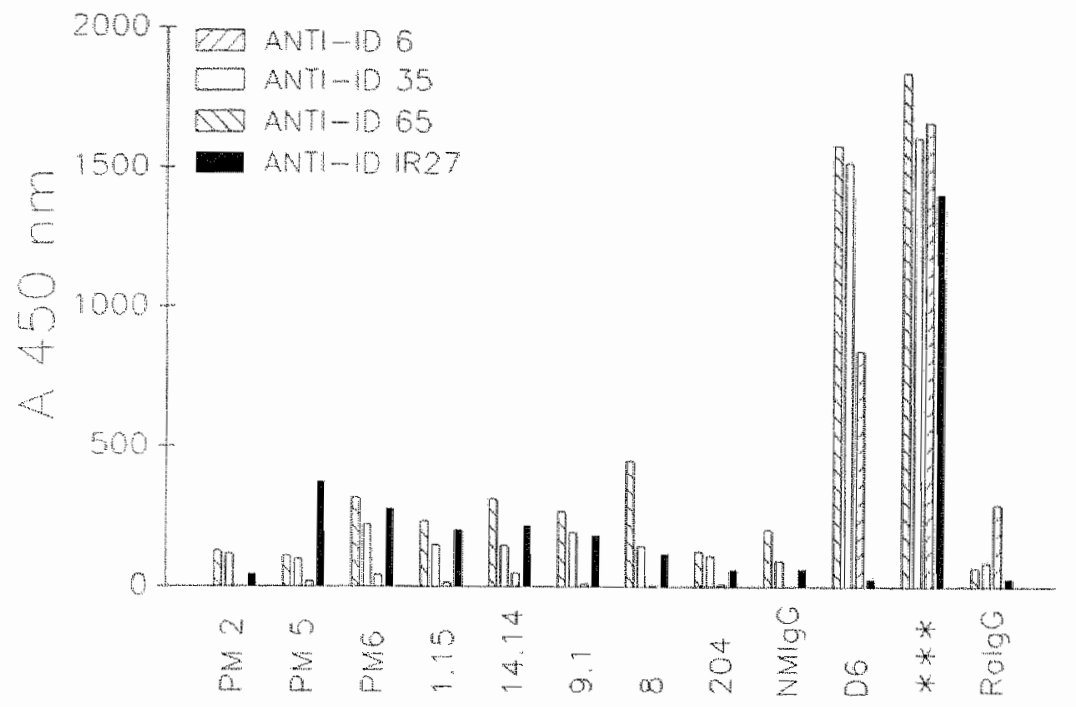

FIGURE 5.5 Anti-Id's bind to CRI's shared by rat and mouse. CRI's on mouse mA $b^{\prime} s$ were analysed by an indirect anti-Id binding ELISA. Mouse mAb's directed at carcinoembryogenic antigen (PM2, PM5, PM6), thyroglobulin (1.15, 14.14,9.1), or CMV virus (mAb) 8, and 204), normal mouse IgG (NMIgG), Lewis rat IgG (RalgG), anti-human AChR mAb D6, or several rat anti-AChR $m A b^{\prime} s$ were coated on microtiter plates. The plates were incubated with anti-Id, and then with goat-anti-rabbit-HRP. Affinity purified anti-Id 6 , anti-Id 35, and anti-Id 65 bound to their homologous Id (i.e. respectively $m A b 6, m A b 35, m A b 65$, indicated by ***) and to $m A b D 6$, but not to any other mouse $m A b$ nor polyclonal mouse or rat $\mathrm{IgG}$. Control anti-Id IR27 bound only to its homologous Id (i.e. IR 27, indicated by ****).

\section{Analysis of interspecies crossreactivity}

The expression of interspecies crossreactive idiotopes was determined by analysing the binding of anti-Id 6, anti-Id 35 and anti-Id 65 to mouse mAb D6, eight control mouse $\mathrm{mAb}$ 's, normal polyclonal mouse $\mathrm{IgG}$, rat $\mathrm{mAb} 6,35,65$, and normal rat IgG. MAb D6 and the rat anti-AChR mAb's are elicited against AChR's from different species, but bind to a phylogenetically conserved epitope on the AChR, i.e. the MIR. All three anti-Id's recognized mAb D6, but none of the control mouse mAb's, nor polyclonal Balb/C or Lewis $\mathbb{g g G}$ was recognized. Moreover, control anti-Id IR27 only recognized mAb IR27, but not mAb D6 or any of the control mAb's (Fig 5.5). 


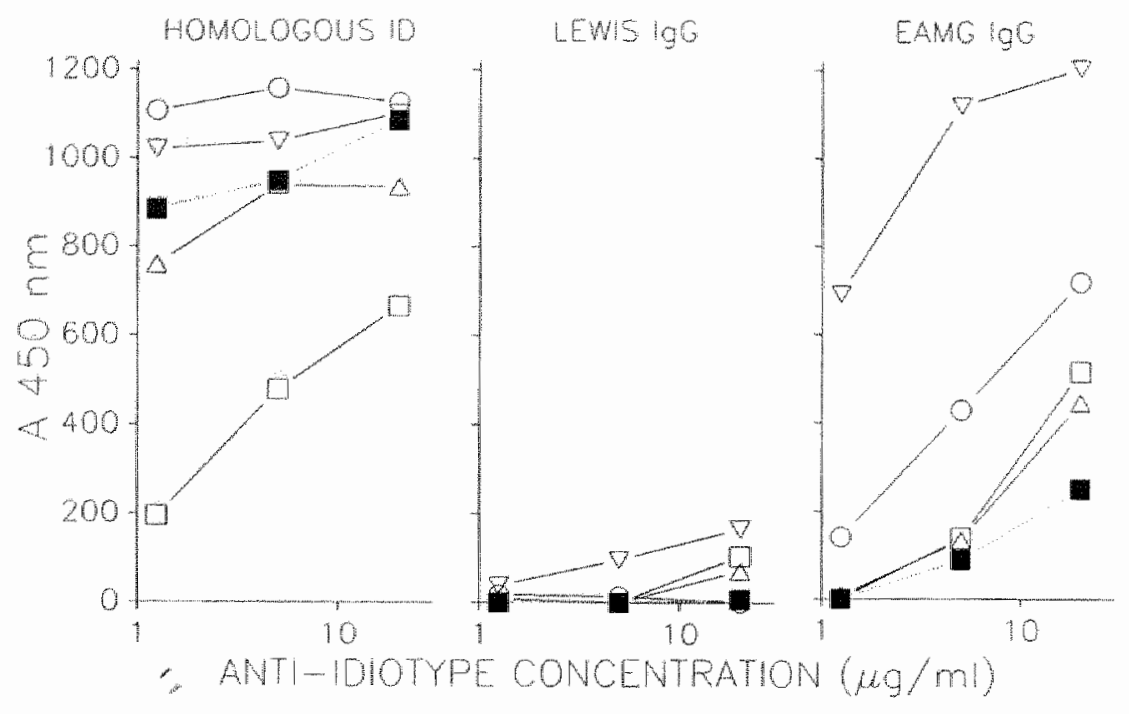

FIGURE 5.6 CRI's are expressed in EAMG serum. Presence of CRI's in EAMG serum was analyzed by an indirect anti-Id binding ELISA. Monoclonal anti-AChR amibodies (left-hand column), normal Lewis IgG (middle column), or affinity purified EAMG IgG (right-hand column) were caated on microtiter plates, as indicated at the top of each column. Plates were incubated with polyclonal anti-Id" s, followed by goat-anti-rabbit-HRP. Anti-Id"s bound to their homologous Id (left hand column) and to the affinity purified EAMG IgG (right hand column), but not to pre-immune IgG (middle column); Id 6 (open circles), Id 35 (open triangles), Id 61 (open squares), Id 65 (open inverse triangles), IdIR27 (filled squares).

\section{Analysis of $\mathrm{V}_{H}$ gene family usage}

In view of the restricted usage of $\mathrm{V}_{\mathrm{H}}$ gene families by autoantibodies, the structural basis for these CRI's was investigated by analysing the $V_{H}$ gene families. By slot blot analysis of cytoplasmic RNA lysates from hybridoma cell lines using 9 mouse probes it was found that probe $V_{H}$ Q52 recognized hybridoma 6 and 35 to the same extent as mouse hybridoma"s from the Q52 family. Hybridoma 61, 65, and 155 were positive for the $\mathrm{V}_{\mathrm{H}} \mathrm{PC7} 183$ family probe $\left(\mathrm{V}_{\mathrm{H}} 81 \mathrm{X}\right)$. No hybridisation of any other probe was observed.

\section{Expression of crossreactive idiotopes in polyclonal EAMG serum}

Subsequently the expression of these CRI's was studied on polyclonal anti-AChR antibodies present in the serum of rats with EAMG. The binding of the anti-Id's to affinity purified rat anti-AChR serum antibodies was determined in an indirect Id 


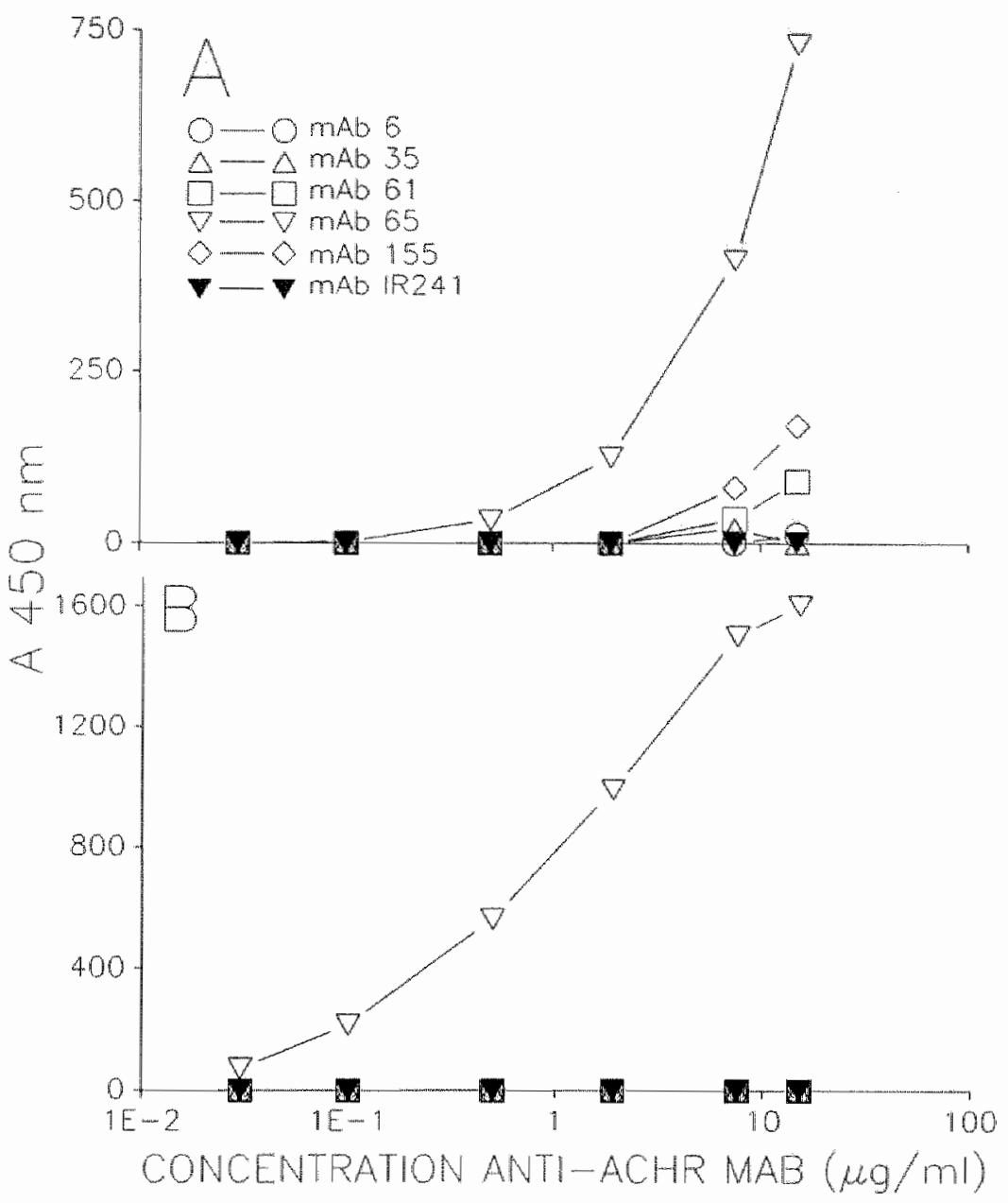

FIGURE 5.7 Monoclonal anti-Id 65 antibodies recognize private Id's. Binding of anti$A C h R$ mAb's was tested in a direct Id binding ELSA. Microtiter plates were coated with monocional anti-Id 65, and incubated with anti-AChR mAbs labeled with HRP. A: anti-Id mAb 21 B6G8, B: anti-Id mAb 21H10A4. Both monoclonal anti-Ids 65 bind only to anti-AChR $m A b 65$.

binding ELISA. All four anti-Id's, directed at anti-AChR mAb's, but not the control anti-Id IR27, showed sigificant binding (Fig 5.6). Although this indirect binding assay does not allow an exact determination of the Id concentration in the sera, an 
estimation can be made. It was found that, based on a parallel assay with various amounts of anti-AChR $\mathrm{mAb}$ 's, less than $0.1 \%$ of the anti-Torpedo antibodies in the sera were Id-positive.

The inhibition of the binding of the affinity purified rat anti-AChR serum was studied in a solid phase antigen binding inhibition RIA. None of the anti-ids was able to inhibit the binding of the EAMG serum antibodies to Torpedo AChR.

\section{Production of monoclonal anti-idiotypes}

Anti-Id's were produced in BALB/c mice for the analysis of the Id of anti-AChR mAb's. MAb 65, directed against the MR of the fetal calf $A C h R$, was used for the generation of monoclonal anti-Id's in BALB/c mice. Two fusions, using lymphnode cells, resulted in the production of 14 ( $3 \%$ of growing hybridoma's) respectively 2 (2\%) stable anti-Id 65 clones. Of these 16 clones 2 were selected for subcloning and purification (mAb 21H10A4 and mAb 21B6G8).

Specificity of these anti-Id mAb's was tested in an direct Id binding ELISA (Fig 5.7). Both monoclonal anti-Id's were found to be specific for $\mathrm{mAb} 65$, and did not bind to any of the other 4 anti-AChR mAb's or control mAb.

Next, it was investigated whether these anti-Id's recognized paratope related Id's on the anti-AChR mAb's. It was found that anti-Id mAb $21 \mathrm{H} 10 \mathrm{~A} 4$ inhibited the binding of mAb 65 to Torpedo AChR up to $100 \%$ (I50: $0.03 \mu \mathrm{g} / \mathrm{ml}$ ), but not of the other anti-AChR mAb"s (Fig 5.7). MAb 21 B6G8 did not inhibit the binding of any of the 5 anti-AChR mAb's tested.

\section{Discussion}

In this study the presence of CRI's was investigated in a rat model for MG. Idiotypes were analysed on rat and mouse mAb's against epitopes on AChR from different species. A large number of paratope and framework related CRI"s were identified on anti-AChR mAb's using polyclonal rabbit anti-Id's.

Sharing of paratope related Id's was found only on mAb's directed against the MIR. This epitope forms an immunodominant determinant on the AChR, to which the majority of serum antibodies in EAMG (55-62\%) (40) and MG (39-80\%) $(10,41)$ are directed. The MIR is an evolutionary conserved immunogenic structure on the AChR (40). This is also indirectly demonstrated by the fact that the CRI's were detected on $\mathrm{mAb}$ 's which originated from independent fusion experiments, and were elicited against AChR's from different species in distinct rat strains 
$(38,39,40)$. Together these results suggest that more anti-MIR mAb's, maybe also other mammalian or even human anti-MIR anti-AChR mAb"s, with similar fine specificity might share these CRI's.

MAb 65, directed against mammalian $A C h R$, was most suitable to study the paratope-related CRI's using Torpedo AChR instead of the proband antigen. Only the binding of $\mathrm{mAb} 65$ to Torpedo AChR could be inhibited by all 3 anti-Id's elicited against anti-MIR antibodies, while the binding of the other anti-MIR mAb's (Mab 6 and 35) was only inhibited by the homologous anti-Id. This can be explained by differences in affinity. MAb 6 and 35 have much higher affinity for Torpedo AChR than mAb 65, since they are elicited against Torpedo AChR respectively eel AChR $(39,40)$, while mAb 65 was obtained after immunization with fetal calf AChR (38). To further define paratope-related Id's of anti-MIR antibodies monoclonall anti-Id's were prepared. The hybridoma cell line (mAb 21H10A4) elicited against anti-MIR $\mathrm{mAb} 65$, secreted monoclonal anti-Id's binding to a paratope related Id. However, the Id recognized by mAb $21 \mathrm{H} 10 \mathrm{~A} 4$ appeared to be a private Id. Although this demonstrated the feasibility of preparation of blocking monoclonal anti-Id's, additional fusions will be needed to select the appropiate monoclonal anti-Id's against paratope-related CRI's on anti-MIR antibodies.

Previously, in MG paratope-related CRI's have been identified by one group (17), but not by another (16). In both studies polyclonal anti-Id's elicited against polyclonal human anti-AChR antibodies were used. In mice CRI's associated with the antigen binding site were reported (31), using polyclonal mouse anti-Id serum elicited against AChR-educated lymphocytes. This anti-Id preparation inhibited the binding of 6 different mouse strains tested, up to a maximum of $45.7 \%$. Other groups also studied monoclonal anti-AChR antibodies. Paratope related CRI's were reported on 4 of the $5 \mathrm{mAb}$ 's derived from Lewis rats (18). It was suggested by others (13) that these crossreactions might be explained by the fact that 3 of their 4 crossreacting mAb's were derived from a single rat. The latter group reported negative results using polyclonal anti-Id 35 to analyze paratope related Id's on anti-MIR antibodies, among which also mAb 6, 35, and 65 (13). Their assay for the detection of paratope related CRI's was similar to ours, but they used serum instead of affinity purified anti-Id to inhibit the binding of the anti-AChR mAb's to AChR. The use of affinity purified antibodies enabled us to test higher amounts of inhibitor, which probably explains why we were able to detect the presence of the paratoperelated CRI's.

Except for paratope-related crossreactivity we also analyzed sharing of framework Id's by inhibition studies of Id-anti-Id binding. These Id-anti-Id inhibition studies do not distinguish between paratope or framework related CRI's. However, know- 
ing that the presence of paratope related CRI's was restricted to the anti-MIR antibodies, additional CRl's found by these assays could be attributed to framework determinants.

Only private Id's were detected when the inhibition of homologous Id-anti-Id interactions (eg. mAb 35 binding to anti-Id 35) was tested. As an example, the binding between mAb 6 and anti-Id 6 was only inhibited by mAb 6 itself (I50 of 0.25 $\mu \mathrm{g} / \mathrm{ml})$, but not by heterologous mAb's tested up to $250 \mu \mathrm{g} / \mathrm{ml}$. However, when the inhibition of heterologous Id-anti-Id binding (eg. mAb 6 binding to anti-Id 35) was investigated a large crossreactivity with very similar patterns for all five anti-Id"s was found. These Id-anti-Id interactions could be inhibited by all 5 anti-AChR mAb's, but not by the 2 control myeloma proteins. These results can be explained by the fact that the anti-Id's exhibit a much lower affinity for the heterologous Id's than for their homologous Id's.

We excluded residual anti-allotype or anti-isotype reactivity in several ways. First, it was shown that control myeloma proteins were not recognized by the anti-Id's, elicited against anti-AChR mAb's, and were not able to inhibite the criss-cross interactions of these anti-Id's. Next, anti-Id IR27, prepared against a myeloma protein of identical iso- and allotype as mAb 65, did not recognize any of the anti-AChR mAb's, and its binding to IR27 could only be inhibited by the homologous Id itself and not by the anti-AChR mAb's, Torpedo AChR, or even IR241. For additional analysis of the framework related Id's monoclonal anti-Id's were prepared. Sofar, one monoclonal anti-Id was obtained recognizing a framework Id on mAb 65. Further fusions will have to clarify if it is possible to prepare monoclonal anti-Id's which show a broader crossreactivity.

Studies concerning CRI's provided no detailed information about the presence of framework related CRI's in MG $(16,17,32,33,41)$ or in EAMG $(1,8,13,18)$. A previous study in EAMG demonstrated a broad crossreactivity between polyclonal anti-AChR antibodies of various mice strains, rat, rabbit and even monkey. This extensive crossreactivity most likely also included framework CRI's, although this was not explicitly stated (31). Moreover, in studies on mouse anti-AChR mAb's the same group could only identify private Id's (34).

For the interpretation of these data it is important to consider the structural basis for these CRI's.

The sharing of paratope related CRI's among anti-MIR mAb's can be explained by the fact that their paratopes contain similar conformational structures, as each mAb recognizes the same epitope on the AChR and each inhibits the binding of the other two $(15,38,39,40)$. These similarities in three dimensional structure of the paratope can be independent of the $V_{H}, V_{L}, D$, or $J$ gene families used, and the recognition 
by anti-Id's can be based on the presence of internal image like antibodies, which only have to resemble the antigen, i.e. the MIR, in the disposition of contact residues (30).

For framework CRI's a different mechanism must be sought to explaiñ crossreactivity. These CRI's were found on anti-AChR mAb's against both intracellular and extracellular epitopes, clearly of different fine specificity. Examples of shared idiotypy among monoclonal antibodies, differing in their fine specificities have been described in several systems $(22,24,25,50)$. One explanation would be that in responses to autoantigens, like the AChR or thyroglobuiin, a restricted Id repertoire is used. Shared idiotopes among antibodies encoded by the same $V_{H}$ gene family, but of different antigen specificity have been described (47). Studies of murine

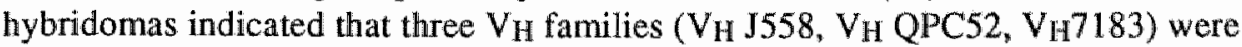
primarily utilized in autoimmune responses in mice $(23,25)$. Also our rat mAb's seem to use equivalents of two of these $V_{H}$ families, when analysed with mouse probes. The CRI's, associated with these $\mathrm{V}_{H}$ families, could be seen as $\mathrm{V}_{H}$ gene markers (3), as described for anti-alprenololantibodies (26). In the latter study, the presence of the defined idiotype was present also on unrelated mAb's. In our study, the framework Id's were found sofar only on $\mathrm{mAb}$ 's directed at various epitopes on the AChR. These framework Id's, however, were not restricted to one $V_{H}$ gene family. This is in concordance with a previous study on autoantibodies were CRI's were shared by murine autoantibodies independent of the $V_{H}$ gene family which was used (25).

It also has been suggested that early appearing multispecific $B$ cells act in a cascade-like set of interactions and are responsible for the selection of later appearing Id's $(42,43)$.

An other possibility of selecting certain idiotypes in the immune response towards an antigen is by means of regulatory idiotypes (ReI) $(28,49)$, or anti-idiotypical T cells regulating restricted Id positive cell populations (11).

The CRI's, described in this study, were found to be present in low concentration in EAMG serum. All anti-Id's, except the anti-myelomat anti-Id, recognized the corresponding idiotypes on affinity purified polyclonal rat anti-AChR serum, but the binding to Torpedo AChR could not be inhibited by these anti-Id's. Further, pollyclonal serum anti-AChR antibodies were not able to inhibit homologous or heterologous Id-anti-Id interactions.

An explanation could be that the identified Id's are only present on a very small percentage of the antibodies in the polyclonal anti-AChR response in EAMG. However, from the sharing of paratope-related Id's among anti-MIR antibodies and the fact that these antibodies form the majority of the antibodies in EAMG $(10,40$, 41), it would be expected that the anti-Id's, elicited against these anti-MIR mAb's, bound the majority of the EAMG antibodies. Therefore, perhaps only a subpopula- 
tion of the anti-Id's is directed at CRI's, which can only be detected by the use of purified monoclonal anti-AChR antibodies. Finally, also differences in affinity, as examplified by the inhibiton studies using $\mathrm{mAb} 65$, might hamper the detection of these CRI's in EAMG serum.

This problem could be solved by preparing the appropriate monoclonal anti-Id's. One monoclonal anti-Id, indeed binding a paratope-related CRI on an anti-MIR $\mathrm{mAb}$ was obtained, but it only recognized a private Id on $\mathrm{mAb} 65$. It is doubtful whether it will be possible to prepare one monoclonal anti-Id recognizing a paratope-related Id on all anti-MIR antibodies, because even the anti-MIR antibodies themselves form a heterogeneous family in terms of their binding characteristics $(6,39,40)$. On the other hand, the paratope-related Id we found on three totally unrelated anti-MIR mAb's indicates that it might be possible to select an anti-Id with the property of recognizing at least an important part of the anti-MIR antibodies. The MIR, consisting of only 16 amino acids (2), probably consists of very few antigenic determinants. Immune responses towards these epitopes might be similar as for haptens, and quantatively dominated by one Id $(29,35)$. In hapten systems regulation of these Id's is therefore able to affect the total response against the antigen (35).

In light of the exciting applications for these anti-Id's in antigen specific immunotherapies, it will be worthwhile to try and select anti-Id's with the above described properties.

\section{Acknowledgments}

We wish to thank Mieke Henfling for excellent technical assistance, and the Beatrix foundation and the Nederlandse organisatie voor Wetenschappelijk Onderzoek (NWO) for their financial support. 


\section{REFERENCES}

1. Agius MA, Geannopoulos CJ, Fairclough RH, Richman DP (1988) Monoclonal anti-idiotypic antibodies against myasthenia-inducing anti-acetylcholine receptor monoclonal antibodies. Preponderance of nonparatope-related antibodies affecting antigen binding. J Immunol 140:62-68

2. Barkas T, Gabriel JM, Mauron A, Hugehes GJ, Roth B, Alliod C, Tzartos SJ, Ballivet M (1988) Monoclonal antibodies to the main immunogenic region of the nicotinic acetylcholine receptor bind to residues 61-76 of the $\alpha$ subunit. J Biol Chem 263:5916-5920

3. Bona CA (1987) Regulatory idiotopes. In Regulatory Idiotopes. CA Bona, ed. John Wiley and Sons, Inc, New York

4. Bos NA, Meeuwsen CG (1989) B cell repertoire in adult "antigen-free' and conventional neonatal BALB/c mice. I. Preferential utilization of the $\mathrm{CH}$-proximal $\mathrm{VH}_{\mathrm{H}}$ gene family PC7 183. Submitted for publication.

5. Bruning JH, Debie WHM, Dormans PHJ, Meijer H, Bruggeman CA (1987) The development and characterization of monoclonal antibodies against rat cytomegalovirus induced antigens. Archives of Virology 94:55-70

6. Conti-Tronconi B, Tzartos SJ, Lindstrom J (1981) Monoclonal antibodies as probes of acetylcholine receptor structure. II. Binding to native receptor. Biochemistry $20: 2181$ 2191

7. Dau PC, Lindstrom JM, Cassel CK, Denys EH, Shev EE, Spitler LE (1977) Plasmapheresis and immunosuppressive drug therapy in myasthenia gravis. $\mathrm{N}$ Engl J Med 297:1134- 1140

8. Dwyer DS, Vakil M, Kearney JF (1986) Idiotypic network connectivity and a possible cause of myasthenia gravis. J Exp Med 164:1310-1318

9. Gullick WJ, Lindstrom JM (1983) Mapping the binding of monoclonal antibodies to the acetylcholine receptor from Torpedo californica. Biochemistry 22:3312-3320

10. Hohlfeld R, Toyka KV, Tzartos SJ, Carson W, Conti-Tronconi BM (1987) Human T-helper lymphocytes in myasthenia gravis recognize the nicotinic receptor $\alpha$ subunit. Proc Natl Acad Sci 84:5379-5383

11. Rubinstein LJ, Yeh M, Bona CA (1982) Idiotype-anti-idiotype network II. Activation of silent clones by treatment at birth with idiotypes is associated with the expansion of idiotype-specific helper T cells. J Exp Med 156:506-521

12. Jerne NK (1974) Towands a network theory of the immune system. Ann Immunol 125C:373-389

13. Killen JA, Hochschwender SM, Lindstrom JM (1985) The main immunogenic region of acetylcholine receptors does not provoke the formation of antibodies of a predominant idiotype. J Neuroimmunoll 9:229-241

14. Köhler G, Milstein C (1975) Continuous cultures of fused cells secreting antibody of predefined specificity. Nature 256:495-497

15. Kordossi AA, Tzartos SJ (1989) Monoclonal antibodies against the main immunogenic region of the acetylcholine receptor. J Neuroimmunol 23:35-40 
16. Lang B, Roberts AJ, Vincent A, Newsom-Davis $\mathbb{J}$ (1985) Anti-acetylcholine receptor idiotypes in myasthenia gravis analysed by rabbit anti-sera. Clin Exp Immunol 60:637644

17. Lefvert A-K (1981) Anti-idiotypic antibodies against the receptor antibodies in myasthenia gravis. Scand I Immunol 13:493-497

18. Lennon VA, Lambert EH (1981) Monoclonal autoantibodies to acetylcholine receptors: evidence for a dominant idiotype and requirement of complement for pathogenicity. Ann N Y Acad Sci. 377:77-96

19. Lieberman R, Potter M, Mushinski B, Humprey W Jr, Rudikoff S (1974) Genetics of a new $\operatorname{IgV}_{\mathrm{H}}$ (T15 idiotype) marker in the mouse regulation natural antibody to phosphorylcholine. 139:983-1001

20. Lindstrom J, Einarson B, Tzartos SJ (1981) Production and assay of antibody to acetylcholine receptors. Meth Enzymol 74:432-461

21. Lindstrom J, Shelton D, Fujii Y (1988) Myasthenia gravis. Adv Immunol 42:233-284

22. Liu Y, Bona CA, Schulman JL (1981) Idiotypy of clonal responses to influenza virus hemagglutinin. J Exp Med 154:1525-1538

23. Mannheimer Lory AJ, Monestier M, Bellon B, Alt FW, Bona CA (1986) Fine specificity, idiotypy, and nature of cloned heavy-chain variable region genes of murine monoclonal rheumatoid factor antibodies. Proc Natl Acad Sci 83:8293-8297

24. Metzger DW, Miller A, Sercarz EE (1980) Sharing of an idiotypic marker by monoclonal antibodies specific for distinct regions of hen lysozyme. Nature 287:540-542

25. MonestierM, Manheimer-Loru A, Bellon B, Painter C, Dang H, Talal N, Zanetti M, Schwartz R, Pisetsky D, Kuppers R, Rose N, Brochier J, Klareskog L, Holmdahl R, Erlanger B, Alt F, Bona C (1986) Shared idiotopes and restricted immunoglobulin variable region heavy chain genes characterize murine autoantibodies of various specificities. J Clin Invest 78:753-759

26. Nahmias C, Cazaubon S, Strosberg AD (1989) A rabbit antiserum detects a VH J558 subgroup marker highly expressed among anti-alprenolol antibodies. J Immunol $142: 871-876$

27. Newsom-Davis J, Wilson SG, Vincent A, Ward CD (1979) Long-term effects of repeated plasma exchanges in myasthenia gravis. Lancet ii:464-468.

28. Paul WE, Bona C (1982) Regulatory idiotopes and immune networks: a hypothesis. Imimunol Today 3:230-234.

29. Rathbun G, Sanz I, Meek K, Tucker P, Capra JD (1988) The molecular genetics of the arsonate idiotypic system of A/J mice. Adv Immunol 42:95-164

30. Roitt IM, Thanavala YM, Male DK, Hay FC (1985) Anti-idiotypes as surrogate antigens: structural considerations. Immunol Today 6:265-267

31. Schwartz M, Novick D, Givol D, Fuchs S (1978) Induction of anti-idiotypic antibodies by immunisation with syngeneic spleen cells educated with acetylcholine receptor. Nature 273:543-545

32. Shoenfeld $\mathbf{Y}$, Ben-Yehuda O, Messinger $\mathbf{Y}$, Bentwitch Z, Rauch J, Isenberg DI, Gadoth Gadoth N (1988) Autoimmune diseases other than lupus share common anti-DNA idiotypes. Immunol Lett 17:285-290

33. Shulman M, Wilde CD, Köhler G (1978) A better cell line for making hybridomas secreting specific antibodies. Nature 276:269-270 
34. Souroujon $\mathbf{M C}$, Fuchs $\mathbf{S}$ (1986) Idiotypes and anti-idiotypes in experimental autoimmune myasthenia gravis. Ann $N$ Y Acad Sci 475:81-93

35. Strayer DS, Cosenza H, Lee WMF, Rowley DA Kohler H (1974) Neonatal tolerance induced by antibody against antigen-specific receptor. Science 186:640-642

36. Toyka KV, Drachman D, Griffin D, Pestronk A, Windelstein J, Fischbeck K, Dao I (1977) Myasthenia Gravis. Study of humoral immune mechanisms by passive transfer to mice. N Engl J Med 296:125-131

37. Toyka KV, Birmberger K, Anzil A, Schlegel C, Besinger V, Struppler A (1978) Myasthenia gravis: further electrophysiological and ultrastructurall analysis of transmission failure in the mouse passive transfer model. J Neurol Neurosurg Psychiatry 41:746753

38. Tzartos S, Langeberg L, Hochschwender S, Swanson LW, Lindstrom J (1986) Characteristics of monoclonal antibodies to denaturated Torpedo and to native calf acetylcholine receptors: species, subunit and region specificity. J Neuroimmunol $10: 235$ 253

39. Tzartos SJ, Lindstrom J (1980) Monoclonal antibodies to probe acetylcholine receptor structure: localization of the main immunogenic region and detection of similarities between subunits. Proc Natl Acad Sci 77:755-759

40. Tzartos SJ, Rand DE, Einarson BL, Lindstrom JM (1981) Mapping of surface structures of Electrophorus acetylcholine receptor using monoclonal antibodies. J Biol Chem 256:8635-8645

41. Tzartos SJ, Seybold ME, Lindstrom JM (1982) Specificities of antibodies to acetylcholine receptors in sera from myasthenia gravis patients measured by monoclonal antibodies. Proc Natl Acad Sci 79:188-192

42. Vakil M, Kearney JF (1988) Regulatory influences of neonatal multispecific antibodies on the developing $B$ cell repertoire. Intern Rev Immunol 3:117-131

43. Vakil M, Kearney JF (1986) Functional characterization of monoclonal auto-anti-idiotypic antibodies isolated from the early B cell repertoire of BALB/c mice. Eur J Immunol 16:1151-1158

44. Valderrama R, Eggers AE, Moomiy M, Kao PN, Michl J (1988) Treatment of experimental myasthenia gravis with autologous idiotypes linked to muramyl dipeptide. Clin Exp Immunol 73:123 127

45. Verstijnen CPHJ, A rends JW, Moerkerk PTM, Warnaar S, Hilgers J, Bosman FT (1986) CEA-specificity of CEA-reactive monoclonal antibodies. Immunochemical and immunocytochemical studies. Anticancer Research 6:97-104

46. Verstijnen CPHJ, Arends JW, Moerkerk PTM, Pijls M, Kuypers-Engelen B, Bosman F (1989) Colonic epithelium reactive monoclonal antibodies: identification and immunohistochemical locallization of the target epitopes. Histochemistry submitted for publication

47. Victor-Kobrin C, Manser T, Moran TM, Imanishi-Kari T, Gefter M, Bona CA (1985) Shared idiotopes among antibodies encoded by heavy-chain variable region ( $\left.V_{H}\right)$ gene members of the $J 558 \mathrm{VH}$ family as basis for cross-reactive regulation of clones with different antigen specificity. Proc Natl Acad Sci 82:7696-7700 
48. Whiting PJ, Vincent A, Schluep $M_{4}$ Newsom-Davis J (1986) Monoclonal antibodies that distinguish between normal and denervated human acetylcholine receptor. J Neuroimmunol 11:223-235

49. Zanetti M (1985) The idiotype network in autoimmune processes. Immunol Today 6:299-302

50. Zanetti M, De Baets M, Rogers J (1983) High degree of idiotypic cross-reactivity among murine monoclonal antibodies to thyroglobulin. IJ Immunol 131:2452-2457 


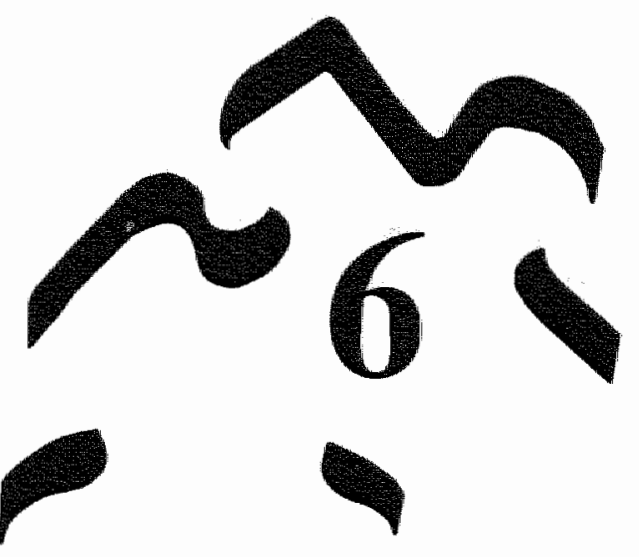

IN VIVO EFFECTS OF NEONATAL ADMINISTRATION OF

\section{ANTIIDIOTYPE ANTIBODIES ON} EXPERIMENTAL AUTOIMMUNE MYASTHENIA GRAVIS IN THE RAT

Jan J.G.M. Verschuuren, Yvo M.F. Graus, Peter J.C. van Breda Vriesman, Marc H. De Baets 


\section{Introduction}

Myasthenia gravis (MG) is an antibody mediated autoimmune disease. Autoantibodies directed against the nicotinic acetylcholine receptor ( $A C h R$ ) can be found in the serum of the majority of patients. Immunopathological lesions found at the neuromuscular junction include complement mediated focal lysis of the sarcolemma, simplifications of the postsynaptic membrane and reduction of the number of AChR $(15,16)$. Antibody mediated AChR loss causes a decreased sensitivity for acetylcholine, resulting in muscular weakness and increased fatiguebility. Multiple initiating events of MG have been proposed, including primary sensitization with AChR by myoid cells in the thymus (23), molecular mimicry of $\mathrm{AChR}$ epitopes by bacteria $(40,41)$, the induction by bacterial antigens of anti-idiotypical antibodies capable of binding the AChR (12), in combination with aberrations in immune regulation $(12,35)$.

The idiotype anti-idiotype (Id-anti-Id) network is one of the systems which might be responsible for regulation of the immune response (22), by maintaining a fine tuned balance between Id and anti-Id within the immune apparatus $(6,12,22)$. Disturbances by exogenous proteins, bacteria or virusses could result in the development of autoimmune diseases including MG (12).

Since the description by Jerne of this network theory, therapeutic manipulation of autoimmunity by anti-idiotypes (anti-Id) has repeatedly been tried. In several systems, using various antigens, succesful modulation of the immune response by anti-Id $(2,17,20)$ has been reported. In MG and experimental autoimmune myasthenia gravis (EAMG) also several attempts were made to identify the idiotypes involved in the autoimmune response against the $\mathrm{AChR}$, because well characterized, preferentially dominant idiotypes could form a tool for specific immunotherapies (35). Although some studies reported the identification of a crossreactive idiotype (CRI) in man $(11,30,37)$, and others found CRI in animals $(31,36,38)$ it was also reported that no CRI could be identified $(19,26,29)$. Therefore, no generally accepted dominant CRI has been identified in MG or EAMG.

Nevertheless, attempts to influence the immune response against AChR's in EAMG by adminstration of anti-Id have been reported. Some appeared succesful $(1,13,38)$, and others were not able to show significant effects $(26,31)$. Additionally, the dose of anti-Id administered appears to determine the effect $(34,44)$.

To date, these anti-Id manipulations have been tested in adult animals. In other antigenic systems, however, succesful and long lasting manipulation of the Id-antiId network was achieved in neonatal animals $(2,42)$.

We analyzed the effects of neonatal administration of anti-Id to determine the role of the Id-anti-Id network in the autoimmune response against AChR. We had at our disposal five well characterized anti-AChR mAb's, prepared by Tzartos $(45,48)$. 
Three of these mAb's are directed against the main immunogenic region (MIR) of the AChR, to which a majority of the antibodies in EAMG is directed $(21,46,47)$, thus the possibility of manipulating the idiotype associated with these mAb's could be of therapeutic value. Polyclonal affinity purified anti-Id's, which we had previously characterized (chapter 5), were used for in vivo administration to neonatal rats.

Here, we report the results of neonatal administration of varying doses of polyclonal or monoclonal anti-Id's on the serum anti-AChR antibody titer, idiotype expression, and weight in EAMG.

\section{Material and methods}

\section{Animai model of experimental autoimmune myasthenia gravis}

The animals used, the preparation of Torpedo acetylcholine receptor (AChR), the induction of EAMG, the assays to determine anti-AChR antibody titers, the determination of weight loss and clinical condition, and the measurement of AChR and AChR-antibody complexes were all similar as described in chapter 2 and 3.

\section{Monoclonal anti-AChR antibodies}

Hybridoma's secreting anti-AChR mAb 6 (IgG1, Lewis), mAb 35 (IgG1, SpragueDawley), mAb 61 (IgG $2 \mathrm{a}$, Lewis), $\mathrm{mAb} 65$ (IgG1, Louvain) were all produced in rats. MAb"s are described in detail in chapter 5 .

\section{Antiidiotypic antibodies}

Polyclonal anti-Id's, prepared in rabbits against anti-AChR mAb 6, 35, 61, 65 and against myeloma protein IR241 or IR27, and monoclonal anti-Id's $21 \mathrm{H} 10 \mathrm{~A} 4$ (IgG1, $\mathrm{BALB} / \mathrm{c})$ and $21 \mathrm{~B} 6 \mathrm{G} 8\left(\mathrm{IgG}_{1}, \mathrm{BALB} / \mathrm{c}\right)$ were described in chapter 5 .

\section{Neonatal treatment}

Affinity purified polyclonal anti-Id's or monoclonal anti-Id's diluted in $200 \mu \mathrm{IBS}$ were administrated intraperitoneally on day 2 or 3 after birth to neonatal female Lewis rats.

\section{Adoptive transfer}

Recipient female Lewis rats, eleven weeks of age, were irradiated (600 Rad). Next day eleven weeks old neonatally pretreated rats were sacrified. Spleens were collected, freed from attached tissue and dissected. Cells were wassed with Kryrode medium (containing $0.14 \mathrm{M} \mathrm{NaCl}, 2.95 \mathrm{mM} \mathrm{KCl}, 0.45 \mathrm{mM} \mathrm{MgSO}_{4} .7 \mathrm{H}_{2} \mathrm{O}, 5.55 \mathrm{mM}$ 
glucose, $11 \mathrm{mM} \mathrm{Na} 2 \mathrm{HPO}_{4} .2 \mathrm{H}_{2} \mathrm{O}, 0.002 \mathrm{~N} \mathrm{HCl}, 0.748 \mathrm{mM} \mathrm{CaCl}_{2}, 0.00066 \mathrm{w} / \mathrm{v} \%$ phenolred) with $5 \mathrm{v} / \mathrm{v} \%$ fetal calf serum and $1 \mathrm{w} / \mathrm{v} \%$ penicilline/streptomycine, followed by purification on Percoll ( $30 \%$ and $80 \%, 1800 \mathrm{rpm}, 15 \mathrm{~min}$ ). Interphase was taken and washed twice with Kryrode medium. Viable spleen cells $\left(5.10^{7}\right.$ in 0.5 ml) were transferred i.v. to each irradiated recipient. Twenty-four hours later all animals were immunized with $20 \mu \mathrm{g}$ Torpedo-AChR in $200 \mu \mathrm{l} \mathrm{CFA}$.

\section{Affinity purification of anti-AChR antibodies}

Serum of 6-11 rats $(1 \mathrm{ml} / \mathrm{rat})$, obtained 6 weeks after immunization with Torpedo AChR, was pooled. Serum IgG was precipitated by adding an equal volume of saturated ammonium sulfate. After dialysis against PBS this preparation was affinity purified, by overnight absorption at $4^{\circ} \mathrm{C}$, on Torpedo $A C h R(1 \mathrm{mg} / \mathrm{ml})$ coupled to $\mathrm{CNBr}$-activated Sepharose $4 \mathrm{~B}$ columns. Elution was performed with $1 \mathrm{~N} \mathrm{HCl}$, containing $0.10 \mathrm{M}$ glycine, $0.15 \mathrm{M} \mathrm{NaCl}, \mathrm{pH} 2.8$. After dialysis against PBS the eluate was used in an indirect idiotype binding ELISA.

\section{Idiotypic analysis of serum antibodies}

a) Indirect idiotype binding assay

Idiotype expression on serum anti-AChR antibodies of EAMG rats was analysed by an indirect idiotype binding ELISA. Polyvinyl 96-well microtiter plates (Greiner, Alphen a/d Rijn, The Netherlands) were coated with $50 \mu \mathrm{l}$ affinity purified antiAChR antibodies $(10 \mu \mathrm{g} / \mathrm{ml})$ for 1 hour at $37^{\circ} \mathrm{C}$. In a parallel assay plates were coated with increasing amounts $(0.1-1 \mu \mathrm{g} / \mathrm{ml})$ of anti-AChR mAb's $6,35,61,65$, or myeloma proteins IR 241 or IR 27 for 1 hour at $37^{\circ} \mathrm{C}$. Plates were washed 3 times with $\mathrm{H}_{2} \mathrm{O}$ containing $0.5 \%$ Tween- 20 (Serva / Brunschwig chemie bv, Amsterdam, The Netherlands) $\left(\mathrm{H}_{2} \mathrm{O}-\mathrm{Tw}\right.$ ), and incubated with PBS containing $0.5 \%$ bovine serum albumen and $0.5 \%$ Tween-20 (PBSA-Tw) for 30 minutes at room temperature. Aliquots of $50 \mu \mathrm{l}$ of increasing concentrations $(0.02-20 \mu \mathrm{g} / \mathrm{ml})$ of affinity purified anti-Id's (anti-Id 6, anti-Id 35, anti-Id 61, anti-Id 65, or anti-Id IR27), normal rabbit IgG (NRIgG) or 1/10 dilution of absorbed anti-Id IR 241 were added and allowed to incubate for 1 hour at room temperature on a rocking platform, before the plates were washed again. Next, $50 \mu \mathrm{l}$ of a 1/5000 dilution goat-antirabbit-HP (Miles / Bayer, Mijdrecht, The Netherlands) was added and allowed to incubate for 1 hour at room temperature on a rocker. After washing with $\mathrm{H}_{2} \mathrm{O}-\mathrm{Tw}$ the colorimetric reaction was developed by adding $100 \mu \mathrm{l}$ of $1.1 \mathrm{M}$ acetate-buffer, $\mathrm{pH} 5.5$, containing tetramethylbenzidine $(0.1 \mathrm{mg} / \mathrm{ml})$ and $0.01 \% \mathrm{H}_{2} \mathrm{O}_{2}$. After 10 minutes the reaction was stopped by adding $50 \mu \mathrm{l} 4 \mathrm{~N} \mathrm{H}_{2} \mathrm{SO}_{4}$. Reading was done at $450 \mathrm{~nm}$ (Titertek Twinreader, Amstelstad, Amsterdam, The Netherlands). Mean of duplicate readings was calculated and NRIgG values were subtracted. 

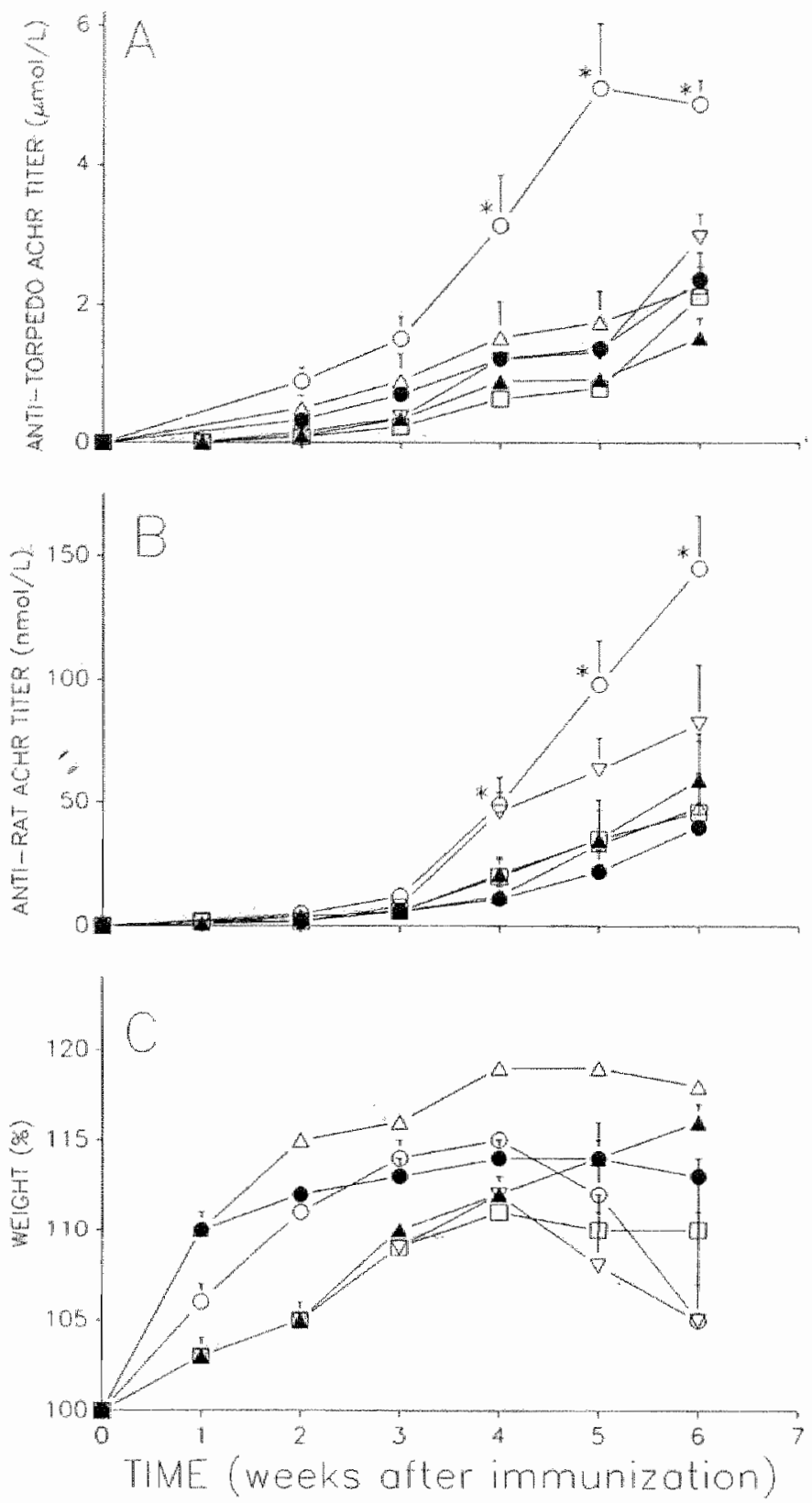

FIGURE 6.1 Enhanced anti-AChR antibody titers by neonatal treatment with $50 \mathrm{ng}$ anti-Id 65. Rats were treated neonatally with increasing amounts of anti-Id 65 (50 ng: open circles, 500 ng: open triangles, $5 \mu \mathrm{g}:$ open squares, $50 \mu \mathrm{g}$ : open inversed triangles), $50 \mu \mathrm{g}$ normal rabbit IgG (closed triangles), or PBS (closed circles). At the age of II weeks all animals were immunized with $20 \mu \mathrm{g}$ Torpedo AChR. Anti-Torpedo AChR titer (upper panel), anti-rat AChR titer (middle panel), and weight (lower panel) were determined weekly. Only rats treated with $50 \mathrm{ng}$ anti-ld 65 show enhanced anti-Torpedo and anti-rat AChR titer (*: $p<0.01)$ and more weight loss compared to the PBS group $(p<0.05)$. 
b) A competitive Id binding ELISA was used to determine Id-positive antibodies in the serum. Inhibition by EAMG sera of both homogeneous (eg. $\mathrm{mAb} 65$ binding to anti-Id 65), as well as heterogenic Id-anti-Id interactions (eg. mAb 35 binding to anti-Id 65) were analyzed. These assays are similar as described in chapter 5, although instead of anti-AChR mAb's, sera from $A C h R$-immunized rats were used as inhibitor.

\section{Statistical analysis}

For statistical analysis the $t$ test and Wilcoxon-Rank test were used (39).

\section{Results}

\section{In vivo effects of administration of polyclonal anti-idiotype}

In vivo effects of anti-Id on the serum antibody response against Torpedo $A C h R$ and rat $A C h R$ were analyzed in 4 different experiments by injecting animals neonatally with affinity purified anti-Id 65, anti-Id 35, normal rabbit IgG (NRIgG), or phosphate buffered saline (PBS).

Animals were infused with increasing doses of anti-Id $65: 50 \mathrm{ng}, 500 \mathrm{ng}, 5 \mu \mathrm{g}$, and $50 \mu \mathrm{g}$, respectively using saline injected rats as controls for the low dose and normal rabbit IgG (NRIgG $50 \mu \mathrm{g}$ ) as controls for the 5 and $50 \mu \mathrm{g}$ treated animals (experiment 1). Only the group injected with $50 \mathrm{ng}$ anti-Id 65 showed a significantly enhanced antibody response against both Torpedo $\mathrm{AChR}$ and rat $\mathrm{AChR}$, administration of higher doses was not effective (Fig 6.1). In this group 3 of the 6 animals were severelly myasthenic as judged by weight loss, while in the PBS control group 1 of the 10 rats ( $p<0.05$ ), and in the NRIgG group 1 of the 7 rats showed loss of weight. Seven weeks after immunization the AChR content in the carcasses was determined (Table 6.1). The total amount of AChR loss was comparable in all experimental groups (55-60\% compared to non-immunized animals). The amount of AChR complexed with antibody was highest in animals neonatally treated with $50 \mathrm{ng}$ anti-Id 65 , namely $80 \pm 11 \%$ compared to $30-53 \%$ of AChR-antibody complexes in the other groups $(\mathrm{p}<0.01)$. The amount of antibody bound to AChR was directly proportional to the serum antibody titer $(\mathrm{r}=0.876, \mathrm{p}<0.001)$.

The effects of neonatal administration of $50 \mathrm{ng}$ polyclonal anti-Id 65 were studied in 3 additional experiments (experiment 2, 3 and 4, Table 6.2). Neonatal rats were treated with either $50 \mathrm{ng}$ anti-Id 65 or anti-Id 35 . This treatment was compared with the administration of PBS or $50 \mathrm{ng}$ NRIgG. In contrast to the experiments described 


\begin{tabular}{lcllll}
\hline & N & $\begin{array}{l}\text { AChR content } \\
\text { pmol/carcass }\end{array}$ & $\begin{array}{l}\text { AChR loss } \\
\%\end{array}$ & $\begin{array}{l}\text { AChR-Antibody } \\
\text { pmol/carcass. }\end{array}$ & $\begin{array}{l}\text { complexes } \\
\%\end{array}$ \\
\hline Control rats & 5 & $61 \pm 4$ & 0 & 0 & 0 \\
PBS $^{\text {b }}$ & 10 & $26 \pm 4$ & $57 \pm 6$ & $10 \pm 6$ & $39 \pm 24$ \\
NRIgG $^{\mathrm{C}}$ & 7 & $27 \pm 5$ & $55 \pm 9$ & $12 \pm 6$ & $51 \pm 30$ \\
Anti-Id $65^{\mathrm{a}} 50 \mathrm{ng}$ & 6 & $24 \pm 3$ & $60 \pm 5$ & $19 \pm 3$ & $80 \pm 11$ \\
Anti-Id $65500 \mathrm{ng}^{11}$ & $27 \pm 5$ & $56 \pm 8$ & $7 \pm 6$ & $30 \pm 29$ \\
Anti-Id $655 \mu \mathrm{g}$ & 9 & $25 \pm 3$ & $59 \pm 5$ & $7 \pm 6$ & $30 \pm 26$ \\
Anti-Id $6550 \mu \mathrm{g}$ & 7 & $25 \pm 4$ & $59 \pm 6$ & $14 \pm 6$ & $53 \pm 18$ \\
\hline
\end{tabular}

TABLE 6.1 AChR loss and achr antibody complexes

$A C h R$ loss and $A C h R$ antibody complexes in rats neonatally treated with increasing doses $(50 \mathrm{ng}, 500 \mathrm{ng}, 5 \mu \mathrm{g}$, or $50 \mu \mathrm{g})$ of anti-ld $65^{\mathrm{a}_{\mathrm{n}}}$ phosphate buffered saline $(P B S)^{b}$, or $50 \mu \mathrm{g}$ normal rabbit IgG (NRIgG) ${ }^{C}$. At the age of 11 weeks all rats were immunized with $20 \mu \mathrm{g}$ Torpedo AChR, except control rats which were untreated and not immunized. Values are obtained by analyzing the carcasses at 6 weeks after immunization and are expressed as mean \pm standard deviation.

above, no significant enhancement of serum antibody titer against Torpedo AChR or rat $\mathrm{AChR}$, nor significant differences in weight were found comparing the anti-Id 65 or anti-Id 35 treated groups with the PBS or NRIgG treated rats. For example, at 2 weeks after immunization the mean anti-Torpedo titer in the PBS groups varied from 587 to $776 \mathrm{nmol} / \mathrm{L}$, compared to 588 to $956 \mathrm{nmol} / \mathrm{L}$ in the anti-Id 65 treated groups (Table 6.2). At the same moment the mean anti-rat AChR titers varied from 1.0 to $2.4 \mathrm{nmol} / \mathrm{L}$ in the PBS group, compared to 0.6 to $2.1 \mathrm{nmol} / \mathrm{L}$ in the anti-Id 65 groups. Weight loss did not differ between anti-Id 65 treated groups (range of mean weights at 6 weeks after immunization 105-125\%), compared to PBS treated groups $(102-117 \%)$ (Table 6.2). 
At two weeks after immunization the mean anti-Torpedo AChR titer $(625 \mathrm{nmol} / \mathrm{L})$, the mean anti-rat AChR titer $(0.8 \mathrm{nmol} / \mathrm{L})$, or the mean weight $(102 \%)$ in the anti-Id 35 treated group was not different from the control groups (experiment 4 , Table $6.2)$.

\section{In viwo effects of neonatal administration of monoclonal anti-idiotype}

Except for the effects of neonatal injection with polyclonal anti-Id, also the effects of neonatal administration of $50 \mathrm{ng}$ monoclonal anti-ld were studied. Two mono clonal anti-Id's were compared, one directed at a paratope related Id (mAb 21H10A4), the other at a framework Id on mAb 65 (mAb 21B6G8). Control animals were not treated.

Six weeks after immunization the mean anti-Torpedo $A C h R$ titer in the anti-Id mAb $21 \mathrm{H} 10 \mathrm{~A} 4$ treated group $(6684 \pm 929 \mathrm{nmol} / \mathrm{L})$, or anti-Id mAb $21 \mathrm{~B} 6 \mathrm{G} 8$ treated group $(7946 \pm 529 \mathrm{nmol} / \mathrm{L})$ did not differ from the controlgroup (7988 $\pm 213 \mathrm{nmol} / \mathrm{L})$ (mean $\pm \mathrm{SE}$ ). Analysis of anti-rat antibody titer, or weight loss also revealed no significant differences between these groups (Table 6.2).

\section{Adoptive transfer of anti-AChR response by splenocytes}

The enhancement of the antibody response against the AChR by treatment with 50 ng anti-Id 65 was further investigated by adoptive transfer experiments. Spleen cells obtained from rats, treated neonatally with $50 \mathrm{ng}$ anti-Id 65 or NRIgG, were transferred to irradiated (600 Rad) recipients (Fig 6.2a). Six weeks after immunization animals which had received spleen cells from anti-Id 65 treated animals, as well as rats which had received control spleen cells, both showed a anti-Torpedo antibody titer comparable to the titers of unmanipulated animals with EAMG (respectively $4494 \pm 420 \mathrm{nmol} / \mathrm{L}$, and $3488 \pm 716 \mathrm{nmol} / \mathrm{L}$; mean $\pm \mathrm{SE}$ ) (Fig 6.2).

Differences in titers were found in the antibody response against rat AChR (Fig $6.2 b)$. At 8 weeks after immunization the anti-Id 65 group showed a significant higher anti-rat $\mathrm{AChR}$ response in comparison to the animals which had received spleen cells from NRIgG treated rats $(p<0.05)$ (Fig 6.3). No significant differences in clinical signs of EAMG were found.

\section{In vivo effects of neonatal treatment with anti-Id's on idiotype expression}

It has been described, that anti-Id treatment is able to affect the idiotype expression without affecting the height of the serum antibody response. Therefore, the Id expression was analysed in EAMG sera from 2 experiments (experiment 1 and 4), 


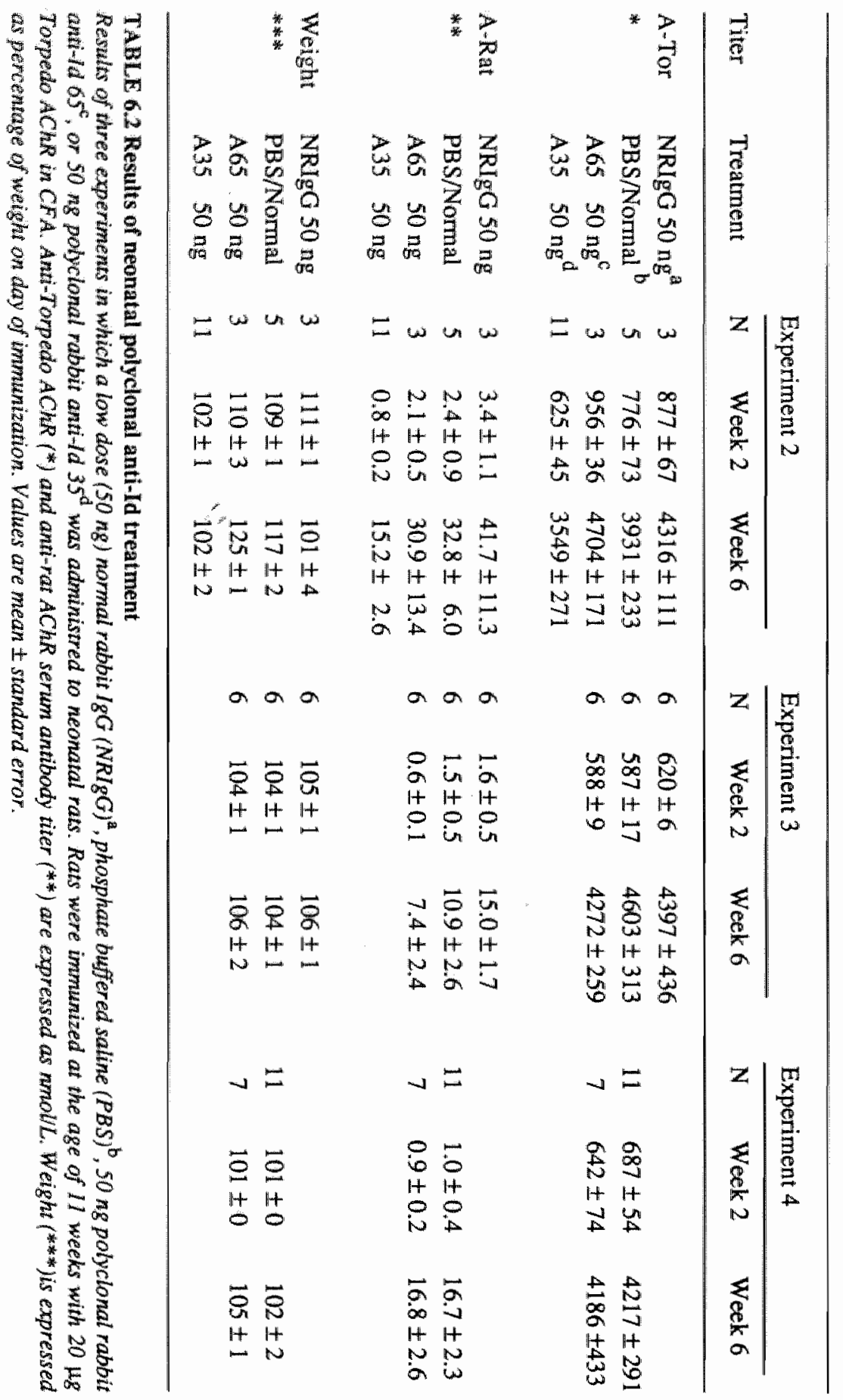



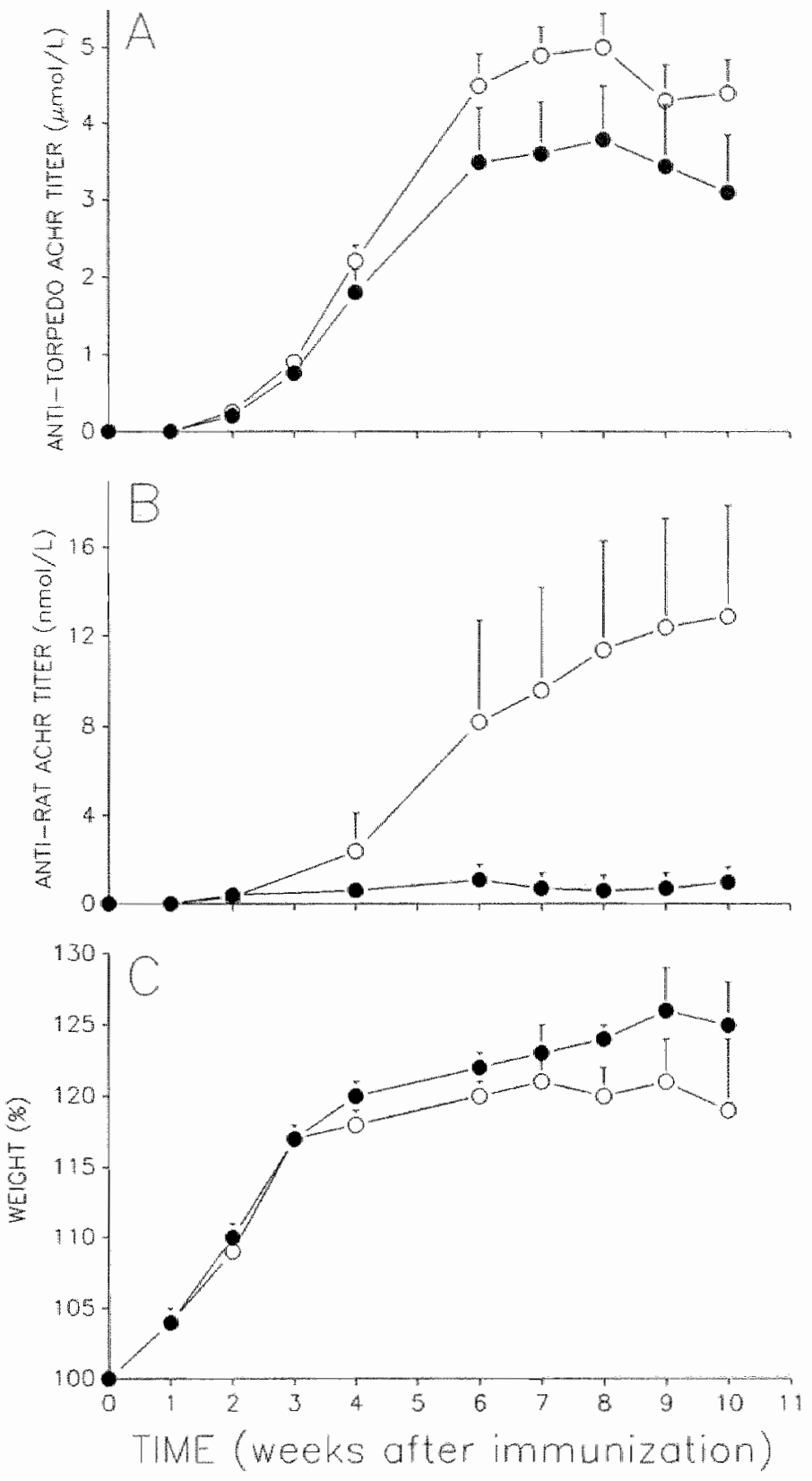

FIGURE 6.2 Enhanced anti-rat AChR antibody titers by adoptive transfer of spleen cells from rats neonatally treated with $50 \mathrm{ng}$ anti-Id 65 . Adult rats were sublethally irradiated and injected intravenously with spleen cells from donors which were neonatally treated with $50 \mathrm{ng}$ anti-Id 65 (open circles) or normal rabbit IgG (closed circles). Next day these rats were immunized with $20 \mu \mathrm{g}$ Torpedo AChR in CFA. Anti-Torpedo AChR viter (upper panel), anti-rat AChR titer (middle panel), and weight (lower panel) were determined weekly. Anti-rat AChR titer was enhanced in the group which had received spleen cells from anti-Id treated donors (at 8 weeks after immunization: $p<0.05$ )). 

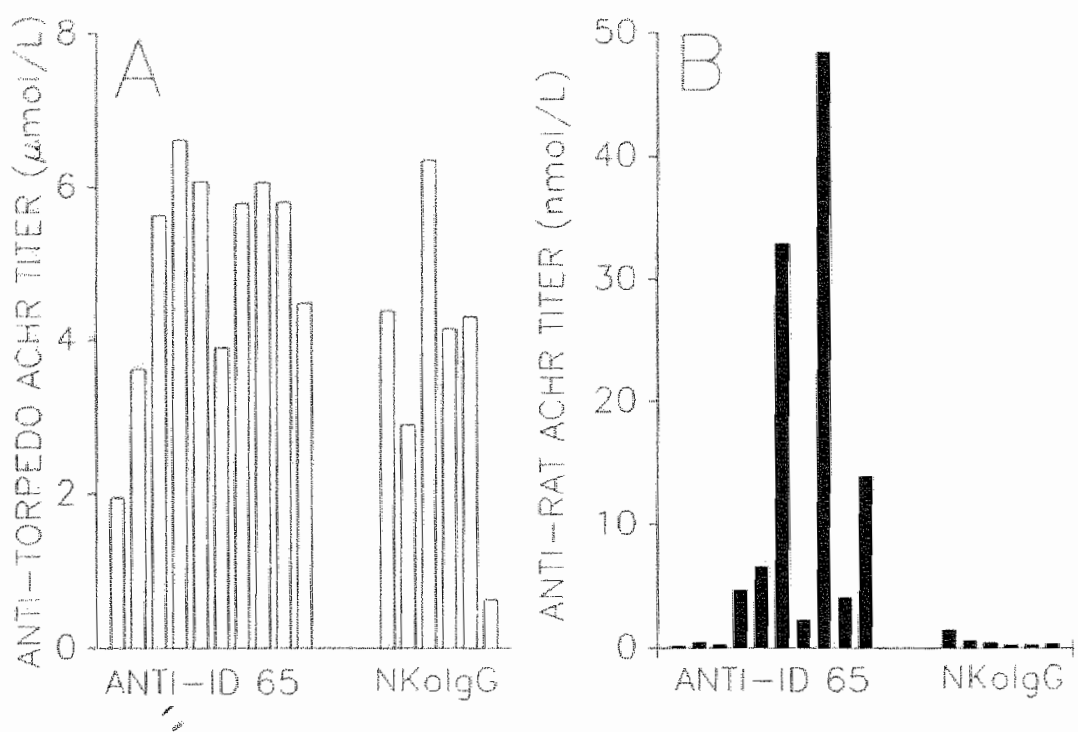

FIGURE 6.3 Enhanced anti-rat AChR antibody titers by adoptive transfer of spleen cells from rats neonatally treated with $50 \mathrm{ng}$ anti-Id $\mathbf{6 5}$. Bars show anti-Torpedo (open bars) and anti-rat $A C h R$ (closed bars) titers of individual rats 8 weeks after adoptive transfer of spleen cells and immunization with $20 \mu \mathrm{g}$ Torpedo $A C h R$. Spleen cells were obtained from donor rats neonatally treated with $50 \mathrm{ng}$ anti-Id 65 or normal rabbit $\mathrm{gg} G$, as indicated at the $X$-axis (compare figure 6.2).

in which animals were neonatally treated with anti-Id 65 , anti-Id 35 or PBS. A competitive binding ELISA was not sensitive enough to detect serum Id 65 or Id 35 (data not shown). Therefore, EAMG serum antibodies were affinity purified, and used in an indirect Id binding assay.

In experiment 4 , in which no effect of anti-Id treatment on anti-AChR antibody titers had been observed, serum levels of Id 6 , Id 35 , Id 61 and Id 65 were comparable between the three groups, and low values of Id IR241 were found (Fig $6.4 a)$. Within each group, Id 65 revealed the highest values, but also in a parallel assay, testing the binding of the anti-Id's to increasing amounts of corresponding monoclonal anti-AChR mAb's, anti-ld 65 showed the highest values. Using this parallel assay for a semi-quantitative determination of the amount of Id in these pooled sera, it was found that the concentrations were similar for all Id's (range $0.1-0.6 \mu \mathrm{g} / \mathrm{ml}$, or $0.674 \mathrm{nmol} / \mathrm{L}$ ). Therefore, maximal $0.1 \%$ of the anti-Torpedo AChR serum antibodies were found to express Id 6 , Id 35, Id 61, or Id 65 (mean anti-Torpedo AChR serum antibody titers varied from 3549 to $4217 \mathrm{nmol} / \mathrm{L}$, Table 6.3) 

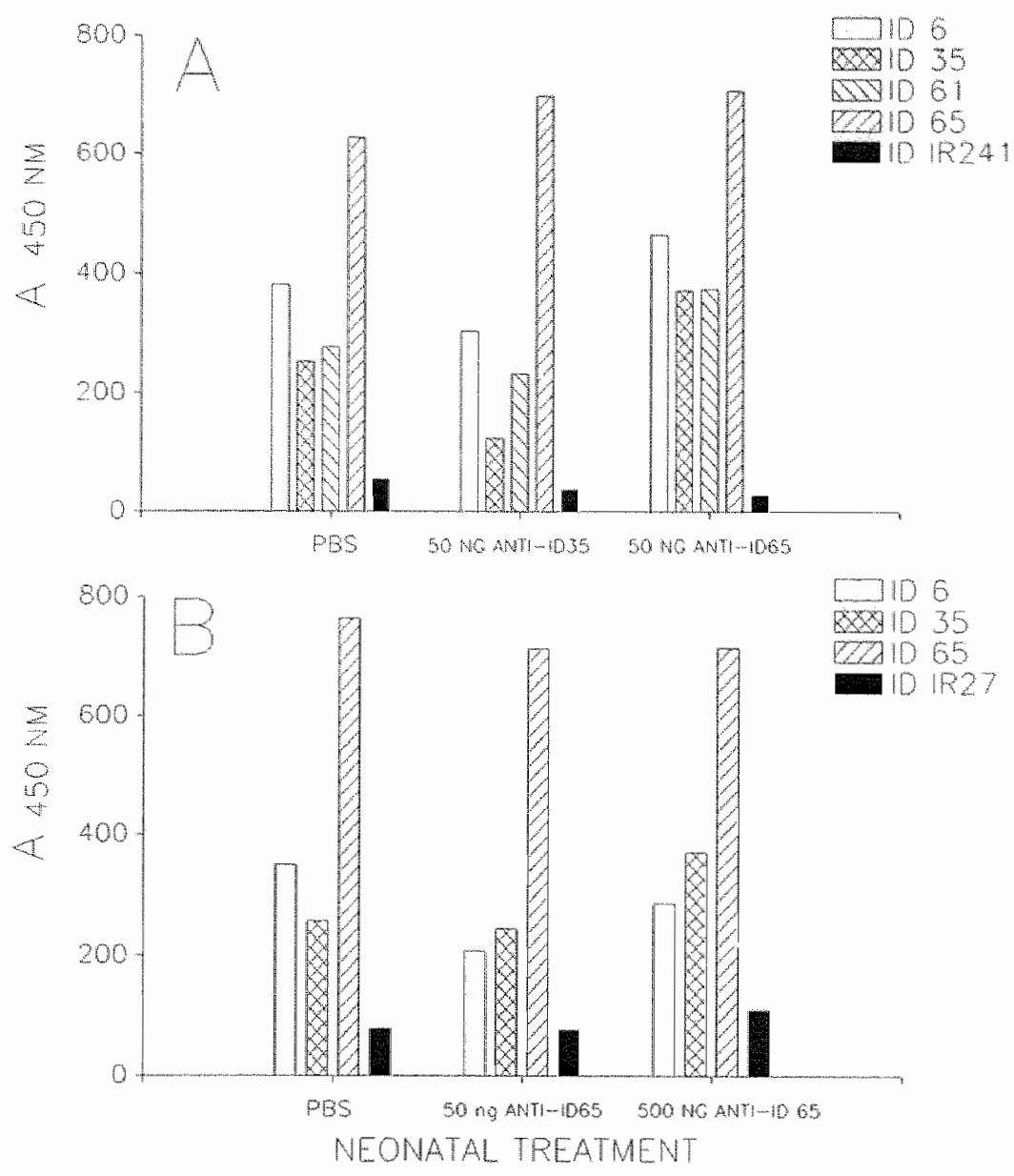

FIGURE 6.4 No difference in Id expression after neonatal treatment with low dose anti-Id 65 or anti-Id 35. A: Rats were neonatally treated with 50 ng anti-Id 35 or anti-Id 65 , and control rats only received $P B S$, as indicated at the $X$-axis. B: Rats were neonatally treated with PBS, or $50 \mathrm{ng}$ anti-Id 65, or $500 \mathrm{ng}$ anti-ld 65, as indicated at the X-axis. At the age of 11 weeks all animals were immunized with $20 \mu \mathrm{g}$ Torpodo AChR. Six weeks after immunization the Id expression was determined in the pooled sera from each group using an indirect Id binding ELISA. Id legend is indicated in the figure and values are expressed as absorption at $450 \mathrm{~nm}$.

In experiment 1 , in which the enhanced anti-Torpedo and anti-rat antibody titers had been found after neonatal treatment with $50 \mathrm{ng}$ anti-Id 65 , Id expression was compared in the groups treated neonatally with PBS, or $50 \mathrm{ng}$ anti-Id 65 , or $500 \mathrm{ng}$ anti-Id 65 . It was found that the expression of Id 6, Id 35, and Id 65 was in the range 
Experiment 5

$\begin{array}{lll}\text { Titer Treatment } & \text { N Week } 3 \text { Week } 6\end{array}$

\begin{tabular}{lllll}
\hline Anti-Torpedo $^{2}$ & Normal & 4 & $2856 \pm 220$ & $7988 \pm 213$ \\
Titer $^{\mathrm{a}}$ & A65mAb 21B6G8 & 6 & $3095 \pm 209$ & $7946 \pm 529$ \\
& A65mAb 21H10A4 & 7 & $2394 \pm 266$ & $6684 \pm 929$ \\
\hline Anti-Rat $^{\text {Titer }}$ & Normal & 4 & $2.8 \pm 0.8$ & $13.2 \pm 2.6$ \\
& A65mAb 21B6G8 & 6 & $6.0 \pm 2.1$ & $18.5 \pm 4.0$ \\
& A65mAb 21H10A4 & 7 & $3.9 \pm 2.0$ & $15.0 \pm 2.2$ \\
\hline Weight $^{\mathrm{c}}$ & Normal & 4 & NT & $108 \pm 1$ \\
& A65mAb 21B6G8 & 6 & NT & $102 \pm 6$ \\
& A65mAb 21H10A4 & 7 & NT & $106 \pm 3$ \\
\hline
\end{tabular}

TABLE 6.3 Results of neonatal monoclonal anti-id treatment

Neonatally a low dose (50 ng) of monoclonal anti-Id 65 (mAb 2IB6G8 or 21H10A4) was injected. At the age of 11 weeks the rats were immunized with $20 \mu \mathrm{g}$ Torpedo AChR in CFA. Anti-Torpedo AChR ( ${ }^{a}$ ) and anti-rat AChR serum antibody titer ( ${ }^{b}$ ) expressed as

of $1.33-2.66 \mathrm{nmol} / \mathrm{L}$ in all three groups. The serum level of control Id IR 27 was in all three groups lower than $1.33 \mathrm{nmol} / \mathrm{L}(0.2 \mu \mathrm{g} / \mathrm{ml})$. Compared to the anti-Torpedo antibody titer of the group treated with $500 \mathrm{ng}$ anti-Id $65(2258 \mathrm{nmol} / \mathrm{L})$ again maximal $0.1 \%$ of the anti-Torpedo antibodies expressed these Id's.

Thus, neither of these two experiments differences in the level of Id 6, Id 35, Id 61 or Id 65 expression could be detected.

\section{In vivo effects of neonatal administration of antigen}

It was asked whether administration of antigen in dosages comparable to the anti-Id 65 treatment, would influence the immune reponse against the AChR. Therefore, the effects of intraperitoneal neonatal administration of $15 \mathrm{ng}$ or $15 \mu \mathrm{g}$ Torpedo AChR in PBS were studied. The control group was injected with PBS alone. In the weeks following neonatal treatment no rat died or showed signs of weakness. 

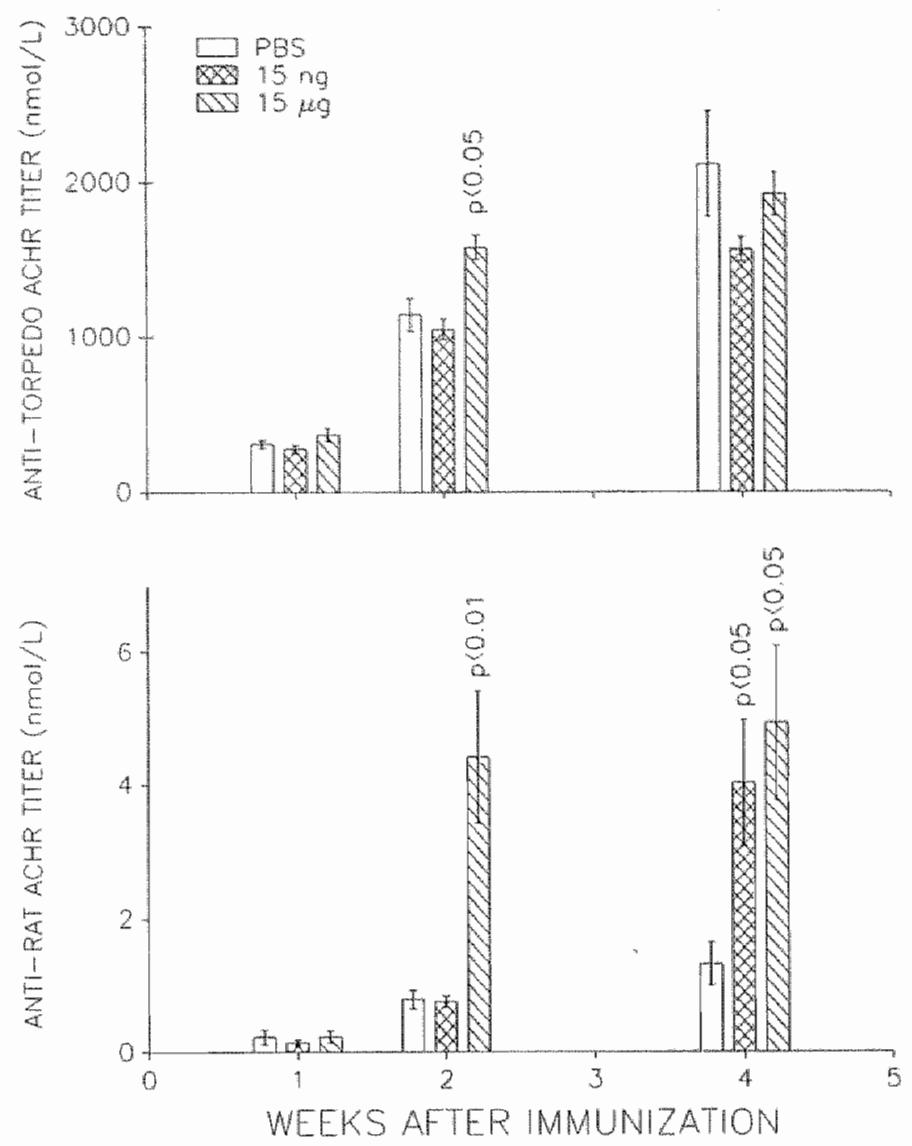

FIGURE 6.5 Enhanced anti-AChR antibody titers by neonatal treatment with Torpedo AChR. Neonatal rats were injected with $15 \mathrm{ng}, 15 \mu \mathrm{g}$ Torpedo AChR, or PBS. At the age of 11 weeks all rats were immunized with $20 \mu \mathrm{g}$ Torpedo AChR. Anti-Torpedo AChR antibody titers (upper panel), and anti-rat $A C h R$ antibody titers (lower panel) were determined weekly. At several weeks after immunization the anti-AChR antibody titers in the Torpedo $A C h R$ treated groups were enhanced compared to control rats, as indicated in the figure.

Weight before immunization in the groups treated with $15 \mathrm{ng}$ or $15 \mu \mathrm{g}$ Torpedo AChR was not different from the PBS treated control group (respectively, $199 \pm 1$, $191 \pm 4$, and $188 \pm 7 \mathrm{~g}$; mean $\pm \mathrm{SE}$ ).

After immunization with Torpedo AChR rats pretreated neonatally with $15 \mu \mathrm{g}$ Torpedo AChR showed an enhanced antibody response 2 weeks after immunization $(1580 \pm 79 \mathrm{nmol} / \mathrm{L}$; mean $\pm \mathrm{SE})$ compared to the PBS treated group (1142 \pm 105 $\mathrm{nmol} / \mathrm{L}$ ), and also an enhanced anti-rat $\mathrm{AChR}$ antibody titer at 2 and 4 weeks after 
immunization (4.41 \pm 0.99 versus $0.79 \pm 0.14$, and $4.92 \pm 1.16$ versus $1.32 \pm 0.32$, respectively; mean $\pm \mathrm{SE}$ ). The group, which had received $15 \mathrm{ng}$ Torpedo $\mathrm{AChR}$ neonatally, showed an enhanced antibcty response against rat AChR at week 4 when compared to the PBS group ( $4.02 \pm 0.94$ versus $1.32 \pm 0.32$ ). The rise of titers in the rats treated with $15 \mu \mathrm{g}$ preceded the development of titers in the $15 \mathrm{ng}$ group (Fig 6.5). No differences in clinical signs of disease, including weight were seen.

\section{Discussion}

Administration of a low dose of polyclonal affinity purified anti-Id 65 to neonatal rats resulted in an increased antibody response to both Torpedo and rat AChR after immunization with AChR at adult age, but only in 1 of 4 experiments. Enhanced anti-rat AChR serum antibody response was also observed after adoptive transfer of spleen cells from rats, neonatally treated with anti-Id 65 , to irradiated recipients. Neonatal administration of higher doses was not effective in influencing the total anti-AChR antibody titer. Monoclonal anti-Id's, injected in low dose, appeared ineffective. On the other hand similar doses of antigen were succesful in neonatal modulation of the immune response against AChR.

In chronic EAMG several attempts have been made to influence the immune response by passive administration of anti-Id $(1,13)$ or by induction of anti-Id by immunization with Id $(26,31,50,46)$. Sofar, some studies were succesful in suppressing the antibody titers or AChR loss $(1,13,38)$, others did not observe an effect on the immune response against $\operatorname{AChR}(26,31)$.

It is most likely that multiple factors determine the succes or failure of anti-Id modulation in an immune response. Variables which have been proposed to play a prominent role are the age of the animals $(3,5,27)$, the fine (multi)specificity of the anti-Id $(8,9,24)$, the time interval between administration of anti-Id and induction of disease $(53,54)$, the dosage of the anti-Id administered (25), and the isotype (14). In addition, polyclonal versus monoclonal $(51,53,54)$, xenogeneic versus syngeneic anti-Id's have been tested $(14,34)$.

In EAMG or MG no dominant Id has been identified $(11,26,29,30,31)$, which could form a point of impact for specific immunotherapy as in other Id models $(3,10)$. Therefore, polyclonal anti-Id's were used in order to provide for the recognition of a large array of Id's. Previous studies, in the levan and phophorylcholine (PC) Id systems, showed that administration of polyclonal anti-Id can be effective in suppressing the immune response $(3,5,27)$. Further, it has also been shown in the 
nitrophenyl (NP) Id system (34) and in the autoimmune response to thyroglobulin $(51,53)$ that modulation of the immune response by allogeneic or xenogeneic anti-Id's can be as effective as the use of syngeneic anti-Id.

Time between anti-Id treatment and induction of EAMG was kept constant at 11 weeks. Previous studies in the NP Id system used a similar time interval of 8-23 weeks (44). On the other hand, studying the PC Id and dextrane (Dex) Id systems by injection of monoclonal anti-Id into neonatal BALB/c mice, it was shown that neonatal anti-Id treatment might only be effective in narrow time windows of only a few days, which differ depending on the antigen (49). Since the time windows for the Id system associated with the anti-AChR response are unknown, our moment of anti-Id treatment at 2 or 3 days after birth might be inappropiate, and partly explain the negative results.

Our rats were treated with increasing doses of anti-Id 65 , since the modulation of the immune response in the NP Id system has been shown to be dose-dependent (34), whereby low doses (nanogram range) have an enhancing (34) and high doses (microgram range) a suppressing effect (44). The dose of anti-Id effective in manipulation of the antibody response was very small. This and the fact that the enhancement of the anti-rat AChR antibody response could be adoptively transferred, makes it unlikely that Id mediated enhancement is the result of direct blocking of B cells by anti-Id 65. Results in the NP idiotype system support these findings, since it was found that suppression by blocking of B cells is most likely to occur with concentrations of anti-Id in the microgram range, and that long-lived effects involves regulatory $T$ (and possibly B cells) $(43,44)$.

Evidence has been presented in the streptococcal carbohydrate associated A5A Id system (14) and in the NP Id system (34) that the subclass of the anti-Id determines its regulatory function, but other studies did not find different effects of Ig subclasses in regulating an immune response in the NP Id system (32) or in the PC Id system $(4,28)$. Our monoclonal anti-Id's 65 , both with the $\mathrm{IgG}_{1}$ isotype, were not effective in influencing the anti-AChR response after neonatal administration at low dose. The failure of these anti-Id mAb's might be due to one or more factors discussed above, since sofar only one dose and one time interval were tested, and other doses might be more succesful $(9,43)$. Further, one of 5 anti-Id's recognizing idiotopes in the combining site of an anti-Ar mAb was ineffective in modulation of the anti-arsonate (Ar) Id response (9).

All previous studies on EAMG employed adult animals. In this study neonatal rats were chosen, because previous studies in the levan and PC Id systems showed that neonatally induced suppression was more profound and lasted longer, than that obtained by treatment of adult animals $(3,5,27)$. 
In the experiment in which low dose anti-Id 65 resulted in an enhanced anti-AChR response, AChR content of muscle was analysed in addition to the analysis of anti-AChR antibody titers and weight. In spite of the differences in clinical severity of EAMG no differences were found in AChR loss. Thus, the anti-Id treatment did not influence $A C h R$ loss. We also found a significant higher amount of $A C h R$ antibody complexes in the muscles of the group with the highest weight loss and titer, but we demonstrated previously that the amount of $\mathrm{AChR}$-antibody complexes is directly proportional to the serum antibody titer, and does not give additional information regarding clinical condition (chapter 2).

Regulation of the overall antibody production by neonatal administration of antiId's in hapten Id models also affects the Id expression $(4,17,44)$. It has been demonstrated in the PC Id model, that downregulation of a quantatively dominant ld (T15), present on about $80 \%$ of the anti-PC antibodies, results also in lower total anti-PC response $(4,17)$. Neonatal treatment in the NP Id system resulted in Id suppression, witkout affecting the total anti-NP titer (44). Therefore, it would be expected that the enhancement of the total antibody response which we observed were associated by an enhanced Id expression. The Id's in this study were expressed on less than $0.1 \%$ of the anti-Torpedo-AChR titer, similar to the value $(0.02-0.08 \%)$ found by Lindstrom for Id 35 (26). Thus, the finding of very low levels of Id-positive serum antibodies after immunization in the Id-manipulated rats argues against Id-driven modulation similar to that described for the abovementioned hapten models.

It might be more appropiate to compare our results with other experimental models for autoimmunity. However, in autoimmune animal models for thyroiditis $(51,52)$, tubulointerstitial nephritis $(7,33,53)$, lupus nefritis (18) or myasthenia gravis $(1,13$, 38) regulation by anti-Id is mainly described for adult animals. The effect of cellular or humoral Id expression in some models was described to be decreased parallel with the total immune response $(18,38,52)$ as would be expected from the results of the hapten models. In other studies the Id was not quantified or not described $(1,7,13,33,51)$, or even enhanced while the total antibody titer was decreased (53). In this latter experiment an Id, constituting only a minor fraction of the total antibody response, was capable of regulating a large fraction of the total immune response, and this suppression could be transferred by $\mathrm{T}$ cells (53), similar to our results. This diversity in results probably reflects the larger complexicity of an immune response against antigens like the AChR or thyroglobulin, which are much larger and have a more complicated structure than the haptens which are studied in various Id systems. 
In conclusion, our results show that neonatal pretreatment with anti-Id fails to modulate reproducibly EAMG in terms of Id expression in the serum, anti-AChR antibody titer and clinical disease since the positive effect observed with low dose anti-Id 65 could not be reproduced in three other experiments. That pretreatment with anti-Id 65 modulates the immune response on the cellular level appeared nevertheless demonstrable in an adoptive transfer model. Hence, these models might be more succesful in analysing the anti-Id treatment of EAMG.

\section{Acknowledgements}

We wish to thank Mieke Henfling and Pauline Storms for excellent technical assistance, and the Beatrix foundation and the Nederlandse organisatie voor Wetenschappelijk Onderzoek (NWO) for their financial support. 


\section{References}

1. Agius MA, Richman DP (1986) Suppression of development of experimental autoimmune myasthenia gravis with isogeneic monoclonal antiidiotypic antibody. J Immunol $137: 2195-2198$

2. Ascolla RS, Gearhart PJ, Sigal NH, Cancro MP, Klimman NR (1977) Idiotype-specific neonatal suppression of phosphorylcholine-responsive B cells. Eur J Immunol 7:876-881

3. Augustin A, Cosenza $\mathbf{H}$ (1976) Expression of new idiotypes following neonatal idiotypic suppression of a dominant clone. Eur J Immunol 6:497-501.

4. Berek C (1983) Antibodies specific for different T15 idiotopes induce neonatal suppression of the T15 idiotype. Ear IImmunol 13:766-772

5. Bona C, Stein KE, Lieberman R, Paul W (1979) Direct and indirect suppression induced by anti-idiotype antibody in the inulin-bacterial levan antigenic system. Mol Immunol 16:1093-1101

6. Bona CA (1987) Regulatory idiotopes. In: Regulatory Idiotopes. CA Bona Ed. John Wiley and Sons, Inc, New York, pp. 152-174

7. Brown CA, Carey K, Colvin RB (1979) Inhibition of auto-immune tubulointerstitial nephritis in guinea pigs by heterologous antisera containing anti-idiotypic antiboclies. J Immunol 123:2102-2107

8. Brown AR (1984) Expression and regulation of two idiotype families and subsets within an idiotype family among BALB/c antibodies against p-azophenylarsonate. I Immunol 132:2715-2723

9. Brown AR, Sealy RE (1986) Regulation of the BALB/c anti-p-azophenylarsonate antibody response by monoclonal anti-idiotype. II. Idiotope expression in serum and its regulation. J Immunol 137:610-617

10. Cosenza H, Köhler H (1972) Specific inhibition of plaque formation to phosphorylcholine by antibody against antibody. Science 176:1027-1029

11. Dwyer DS, Bradley RJ, Urquhart CK, Kearney JF (1983) Naturally occurring anti-idiotypic antibodies in myasthenia gravis patients. Nature 301:611-613

12. Dwyer DS, Vakil M, Kearney JF (1986) Idiotypic network connectivity and a possible cause of myasthenia gravis. J Exp Med 164:1310-1318

13. Dwyer DS, Schonbeck S (1987) Anti-idiotypic regulation of the immune response against the acetylcholine receptor. Imm Reg Char Peptides 607-616

14. Eichmann K (1974) Idiotype suppression. I. Influence of the dose and of the effector functions of anti-idiotypic antibody on the production of an idiotype. Eur J Immunol 4:296-302

15. Engel AG, Tsujihata M (1976) The motor end plate in myasthenia gravis and in experimental autoimmune myasthenia gravis. A quantative ultrastructural study. Ann $\mathrm{N} Y$ Acad Sci 274:60-79

16. Engel AG, Sahashi K, Fumagalli G (1981) The immunopathology of acquired myasthenia gravis. Ann N Y Acad Sci 377:158-174

17. Fung J, Köhler H (1980) Mechanism of neonatal idiotype suppression I. State of suppressed B cells. J Immunol 125:1998-2003 
18. Hahn BH, Ebling FM (1984) Supression of murine lupus nephritis by administration of an anti-idiotypic antibody to anti-DNA. J Immunol 132:187-190

19. Heininger $\mathbf{K}$, Hendricks M, Toyka KV, Kolb H (1983) Myasthenia gravis: remission not induced by blocking anti-idiotypic antibodies. Muscle Nerve 6:386-387

20. Hiernaux J, Bona C, Baker PJ (1981) Neonatal treatment with low doses of ant-idiotypic antibody leads to the expression of a silent clone. J Exp Med 153:1004-1008

21. Hohlfeld R, Toyka KV, Tzartos SJ, Carson W, Conti-Tronconi BM (1987) Human T-helper lymphocytes in myasthenia gravis recognize the nicotinic receptor $\alpha$ subunit. Proc Natl Acad Sci 84:5379-5383

22. Jerne NK (1974) Towards a network theory of the immune system. Ann Immunol 125C:373-389

23. Kao I, Drachman DB (1976) Thymic muscle cells bear acetylcholine receptors: possible relation to myasthenia gravis. Science 195:74-75

24. Kearney JF, Vakil M (1986) Idiotype-directed interactions during ontogeny play a major role in the establishment of the adult B cell repertoire. Immunol Rev 94:39-50

25. Kelsoe $\mathbf{G}$, Reth M, Rajewsky K (1981) Control of idiotope expression by monoclonal anti-idiotope and idiotope-bearing antibody. Eur J Immunol 11:418-423

26. Killen JA, Hochschwender SM, Lindstrom JM (1985) The main immunogenic region of acetylcholine receptors does not provoke the formation of antibodies of a predominant idiotype. J Neuroimmunol 9:229-241

27. Köhler H, Kaplan DR, Strayer DS (1974) Clonal depletion in neonatal tolerance. Science 186:643-644

28. Köhler H, Rüchardson BC, Rowley DA, Smyk S (1977) Immune response to phosphorylcholine III. Requirement of the Fc portion and equal effectiveness of IgG subclasses in anti-receptor antibody-induced suppression. J Immunol 119:1979-1986

29. Lang B, Roberts AJ, Vincent A, Newsom-Davis J (1985) Anti-acetylcholine receptor idiotypes in myasthenia gravis analysed by rabbit anti-sera. Clin Exp Immunol 60:637-644

30. Lefvert A-K, James RW, Alliod C, Fulpius BW (1982) A monoclonal anti-idiotypic antibody against anti-receptor antibodies from myasthenic sera. Eur J Immunol 12:790-792

31. Lennon VA, Lambert EH (1981) Monoclonal autoantibodies to acetylcholine receptors: evidence for a dominant idiotype and requirement of complement for pathogenicity. Ann N Y Acad Sci 377:77-96

32. Müller CE, Rajewsky K (1984) Idiotope regulation by isotype switch variants of two monoclonal antidiotope antibodies. J Exp Med 159:758-772

33. Neilson EG, Philips MS (1982) Suppression of interstitial nephritis by auto-anti-idiotypic immunity. J Exp Med 155:179-189

34. Reth M, Kelsoe G, Rajewsky K (1981) Idiotypic regulation by isologous monoclonal anti-idiotope antibodies. Nature 290:257-259

35. Roitt IM, Male DK, Cooke A, Lydyard PM (1983) Idiotypes and autoimmunity. Springer Sem Immunopathol 6:51-66

36. Schwartz M, Novick D, Givoll D, Fuchs S (1978) Induction of anti-idiotypic antibodies by immunisation with syngeneic spleen cells educated with acetylcholine neceptor. Nature 273:543-545 
37. Shoenfeld $\mathbf{Y}$, Ben-Yehuda $\mathbf{O}$, Messinger $\mathbf{Y}$, Bentwitch Z, Rauch J, Isenberg DI, Gadoth Gadoth N (1988) Autoimmune diseases other than lupus share common antiDNA idiotypes. Immunol Lett 17:285-290

38. Souroujon MC, Fuchs $\mathrm{S}$ (1985) Idiotypes and anti-idiotypes iri experimental autoimmune myasthenia gravis Ainn N Y Acad Sci 475:81-93

39. Statistics at square one (1978) TDV Swinscow Ed, British Medical Association, London

40. Stefansson K, Dieperdink ME, Richman DP, Gomez CM, Marton LS (1985) Sharing of antigenic determinants between the nicotinic acetylcholine receptor and proteins in Escherichiae coli, Proteus vulgaris, and Klebsiella pneumoniae. N Engl J Med 312:221-225

41. Stefansson K, Dieperink ME, Richman DP, Marton LS (1987) Sharing of epitopes by bacteria and the nicotinic acetylcholine receptor: a possible role in the pathogenesis of myasthenia gravis. Proc Natl Acad Sci 505:451-460

42. Strayer DS, Lee WMF, Rowley DA, Köhler H (1975) Anti-receptor antibody II. Induction of longterm unresponsiveness in neonatal mice. J Immunol 114:728-733

43. Takemori T, Rajewsky K (1984) Mechanism of neonatally induced idiotype suppression and its relevance for the acquisition of self-tolerance. Immunol Rev 79:103-117

44. Takemori T, Rajewsky K (1984) Specificity, duration and mechanism of idiotype suppression induced by neonatal injection of monoclonal anti-idiotope antibodies into mice. Eur J Immunol 14:656-667

45. Tzartos SJ, Lindstrom J (1980) Monoclonal antibodies to probe acetylcholine receptor structure: localization of the main immunogenic region and detection of similarities between subunits. Proc Natl Acad Sci 77:755-759

46. Tzartos SJ, Rand DE, Einarson BL, Lindstrom JM (1981) Mapping of surface structures of Electrophorus acetylcholine receptor using monoclonal antibodies. J Biol Chem 256:8635-8645

47. Tzartos SJ, Seybold ME, Lindstrom JM (1982) Specificities of antibodies to acetylcholine receptors in sera from myasthenia gravis patients measured by monoclonal antibody. Proc Natl Acad Sci 79:188-192

48. Tzartos S, Langeberg L, Hochschwender S, Swanson LW, Lindstrom J (1986) Characteristics of monoclonal antibodies to denaturated Torpedo and to native calf acetylcholine receptors: species, subunit and region specificity. J Neuroimmunol 10:235253

49. Vakil M, Kearney JF (1986) Functional characterization of monoclonal auto-anti-idiotype antibodies isolated from the early $\mathrm{B}$ cell repertoire of BALB/c mice. Eur J Immunol $16: 1151-1158$

50. Valderrama R, Eggers AE, Moomiy M, Kao PN, Michl J (1988) Treatment of experimental myasthenia gravis with autologous idiotypes linked to muramyl dipeptide. Clin Exp Immunol 73:123-127

51. Zanetti M, Bigazzi PE (1981) Anti-idiotypic immunity and autoimmunity. I. In vitro and in vivo effects of anti-idiotypic antibodies to spontaneously occurring autoantibodies to rat thyroglobulin. Eur J Immunol 11:187-195

52. Zanetti M, Mampaso F, Willson CB (1983) Anti-idiotype as a probe in the analysis of autoimmune tubulointerstitial nephritis in the Brown Norway rat. J Immunol 131:12681273 
53. Zanetti M, Glotz D, Rogers J (1986) Perturbation of the autoimmune network. II. Immunization with isologous idiotype induces auto-anti-idiotypic antibodies and suppresses the autoantibody response elicited by antigen: a serologic and cellular analysis. Immunol 137:3140-3146

54. Zanetti M, Rogers J, Katz DH (1988) Perturbation of the autoimmune network. I. Immunization with anti-idiotypic antibodies prior to challenge with antigen induces quantitative variations in the autoantibody response. Autoimmunity 1:23-36 


\section{Summary and conclusions}

Myasthenia gravis is an autoimmune disease characterized by an antibody mediated attack to the postsynaptic muscle membrane resulting in impairment of the neuromuscular function. Antibodies to the nicotinic acetylcholine receptor play a central role in the pathogenesis of myasthenia gravis, as demonstrated by (passive) transfer of the disease from mother to neonates or to experimental animals and the beneficial effect in human disease by removing antibodies by plasmapheresis. Specific manipulation of the production of autoantibodies directed at the acetylcholine receptor would be a major therapeutical breakthrough. Detailed information should be available regarding the experimental model for myasthenia gravis in order to study the results of new immunomodulatory strategies.

Therefore, one aim of the studies described in this thesis was to optimize the rat model of experimental autoimmune myasthenia gravis. Secondly, the possibility of regulation of the production of anti-acetylcholine receptor antibodies by idiotypeanti-idiotype interactions was analysed.

Chapter 1 reviews the literature on myasthenia gravis and experimental autoimmune myasthenia gravis. The structure and distribution of the acetylcholine receptor is described, for this molecule is known to be the most important antigen in myasthenia gravis, in terms of clinically relevant autoantibodies. Detailed information about the structure of this molecule is now available; the acetylcholine receptor of fish, mammals and man has been cloned, and the exact amino acid sequence is known. The antigenic determinants of the acetylcholine receptor have been mapped. The more than hundred monoclonal antibodies available recognize several distinct regions on the acetylcholine receptor, including the acetylcholine binding site. The majority of both monoclonal and natural occurring serum antibodies, however, bind to an extracellular epitope, the so called main immunogenic region. The role of $\mathrm{T}$ cells in myasthenia gravis and experimental autoimmune myasthenia gravis has been studied. These lymphocytes are involved in cytotoxic activities and in regulating the immune response. A number of $T$ cell antigenic determinants on the acetylcholine receptor has been identified and found to be different from those recognized by $B$ cells.

Human myasthenia gravis is reviewed briefly, and experimental autoimmune myasthenia gravis is discussed in more detail. Especially, the rat model of chronic experimental autoimmune myasthenia gravis, induced by the immunization with Torpedo acetylcholine receptor is discussed, as this model has been used in the studies described in this thesis. Immunization with Torpedo AChR induces a chronic form of disease which closely resembles human myasthenia gravis in almost every detail, except for the thymic abnormalities, which are only seen in man. Pathomorphology of the neuromuscular junction and mechanisms for attack of the muscle 
endplate are similar in man and animal. The destruction is mediated by antibodies and in chronic experimental autoimmune myasthenia gravis and human myathenia gravis cellular infiltrates in muscle are rarely seen. The autoantibodies have been shown to diminish the amount of acetylcholine receptors at the endplate by antigenic modulation and complement mediated destruction of the muscle membrane, and to block the acetylcholine receptor function by direct binding.

In chapter 2 the relation between anti-acetylcholine receptor antibodies, the amount of acetylcholine receptors in muscle and clinical condition is studied in more detail. In contrast to what might be expected, the loss of acetylcholine receptor by itself does not completely account for the differences in clinical condition between myasthenic animals, since no good correlation between these two parameters was found. Previous studies suggested that the amount of acetylcholine receptor not bound to antibody determines the clinical condition, as in man and rat variable amounts of acetylcholine receptor (extracted from muscle biopsy or carcass) can be shown to be complexed with antibody. We showed, however, that a large amount of acetylcholine receptorantibody complexes are formed in vitro during the extraction of the acetylcholine receptor from muscle, and that there is a very good correlation between the serum anti-acetylcholine receptor antibody titer and the amount of acetylcholine receptorantibody complexes. Therefore, it is concluded that far less acetylcholine receptors are complexed in vivo than has been reported previously. Using an improved method for measuring acetylcholine receptor-antibody complexes no relation between antibody free acetylcholine receptors and disease severity could be detected.

In addition, the presence of anti-acetylcholine receptor antibodies capable of blocking the acetylcholine binding site was analysed. Blocking antibodies were found to be present in similar amounts in the serum of both severely ill myasthenic rats and rats without symptoms of disease.

In chapter 3 stimulated single fiber electromyography is used to detect early signs of experimental autoimmune myasthenia gravis in the rat. Weight loss, clinical symptoms and decrement studies have been used sofar for the evaluation of disease severity in myasthenic rats. From studies in man this electrophysiological technique was known to be more sensitive than decrement studies, as with this technique neuromuscular disturbances can be detected before impulse blocking occurs, thus before decrement can be seen. We tested the sensitivity of stimulated single fiber electromyography for the detection of abnormal neuromuscular function, and compared the findings with decrement studies, clinical symptoms, anti-acetylcholine receptor antibody titers, acetylcholine receptor content and acetylcholine receptorantibody complexes in muscle. 
Stimulated single fiber electromyography was found to be a sensitive diagnostic test in chronic experimental autoimmune myasthenia gravis. Abnormal jitter developed in 7 out of 8 rats immunized with Torpedo acetylcholine receptor, and always preceded decrement of the compound muscle action potential and the development of clinical signs. The severity of abnormalities found by stimulated single fiber electromyography was not proportional to the acetylcholine receptor loss from the gluteus medius muscle, which was used for the electromyographical studies, nor from the carcass. Similar to the results discussed in chapter 3 , this again suggests that the total amount of acetylcholine receptor loss found in muscle is not the only factor responsible for impaired neuromuscular transmission. Therefore, probably other factors contribute also to the abnormal jitter, like variation in structural characteristics of the postsynaptical area, or distribution of acetylcholine or acetylcholine receptors in the enlarged synaptic cleft, or allosteric blocking of acetylcholine receptor function by bound antibodies.

Chapter 4 introduces the second part of this thesis. It describes the terminology of the idiotypes and anti-idiotypes, and the idiotype network theory of Jerne. Analysis of the structure of an immunoglobulin makes it possible to distinguish several antigenic determinants on the different parts of the immunoglobulin. The isotype of an immunoglobulin determines its class and subclass (e.g. IgG1), and is located on the constant region of the molecule. Allotypes refer to determinants only present on immunoglobulins of certain subgroups of a population. Idiotypes are associated with antigenic determinants expressed on the variable region domains ( $\mathrm{V}$ region) of immunoglobulins. An idiotype consists out of a collection of idiotopes. An idiotope can be formed by the $V_{H}$ region, the $V_{L}$ region, or by a combination of both $V$ regions. Idiotopes can be categorized according to their localization, prevalence, crossreactivity, or functional properties. An important category of idiotopes are 'crossreactive idiotopes'. Crossreactive idiotopes are determinants that are shared by different immunoglobulins, and they are important in linking antibodies into an idiotype-anti-idiotype network. This linkage can be established by anti-idiotype antibodies, which bind to the idiotype determinants of an antibody. In 1974 Jerne first proposed that idiotypes and anti-idiotypes were intercomected in a network which plays a crucial role in the regulation of the immune response. Naturally occurring anti-idiotype antibodies have been detected in patients suffering from autoimmune diseases, including myasthenia gravis, and numerous studies now support a regulatory function of anti-idiotype antibodies.

Several idiotype pathways have been proposed as an explanation for the induction of myasthenia gravis. For example, a virus binding the acetylcholine receptor could induce antibodies carrying specific idiotopes. Complementary anti-idiotype antibodies could be structurally similar to the binding site of the virus and therefore be able to bind the acetylcholine receptor. In this way an autoimmune attack against the 
receptor could be elicited. On the other hand micro-organisms could share antigenic determinants with the acetylcholine receptor, instead of being complementary. Then, antibodies directed at these micro-organisms would also bind the receptor. This hypothesis circumvents the need for anti-idiotypes, and postulates that antibodies with similar fine specificity, and probably similar idiotypes, are used in the response against antigenic determinants on both certain micro-organisms and the acetylcholine receptor.

Crossreactive idiotopes may be of therapeutical interest. In some studies these idiotopes are readily demonstrable in myasthenia gravis and in experimental autoimmune myasthenia gravis, while others could not find sharing of idiotopes among anti-acetylcholine receptor antibodies. The use of differing monoclonal and polyclonal anti-acetylcholine receptor antibodies and anti-idiotypes makes comparison between these studies quite difficult. Almost all studies analyse idiotopes related to the antigen binding site of the immunoglobulin, but no analysis is made of the idiotopes related to framework residues. In experimental autoimmune myasthenia gravis several anti-idiotype therapies have been tried. Results reached by these therapies are very different, some studies show a substantial suppression of the anti-acetylcholine receptor antibody titer, while others do not. However, all studies were performed in adult animals, although it is known that neonatal, administration of anti-idiotype antibodies can result in more profound and long lasting effects.

We studied the crossreactive idiotopes, associated with the antigen binding site, and those associated with the framework residues of a serie of well-characterized monoclonal anti-acetylcholine receptor antibodies. Anti-idiotype antibodies against these idiotopes were tested for their regulatory properties in neonatal rats.

Chapter 5 describes the analysis of five anti-acetylcholine receptor monoclonal antibodies and two control myeloma proteins. The idiotype profile of three of these monoclonal antibodies, directed at the main immunogenic region, may be of interest, because these monoclonals are capable of inducing experimental autoimmmune myasthenia gravis, and about $50 \%$ of the anti-acetylcholine receptor antibodies is directed at this main immunogenic region. We were able to identify crossreactive idiotopes associated with the antigen binding site of these monoclonal antibodies directed at the main immunogenic region. In addition, sharing of framework related idiotopes was found between all 5 anti-acetylcholine receptor antibodies. The sharing of binding site related idiotopes can be explained by the fact that these monoclonals, all three directed at the main immunogenic region, bind to overlapping regions on the acetylcholine receptor and therefore share conformational structures in their binding sites. Sharing of framework related idiotopes can not be explained by similarities in the structure of the antigen binding site, as crossreactive idiotopes are found on antibodies of totally different specificity. However, it could be explained by assuming that in response to autoantigens a restricted number of $V_{H}$ gene families is used. 
Sharing of idiotopes among antibodies of the same VH gene family, but of different specificity, has been described. In fact, these crossreactive idiotopes can be seen as $\mathrm{V}_{\mathrm{H}}$ gene markers.

Although crossreactive idiotopes could readily be demonstrated on the anti-acetylcholine receptor monoclonal antibodies, it was quite difficult to demonstrate their presence in serum of myasthenic rats. No crossreactive idiotopes could be demonsirated when inhibition assays were used; only by direct binding of the anti-idiotypes to the affinity purified anti-acetylcholine receptor antibodies could crossreactive idiotopes in myasthenic serum be demonstrated. Less than $0.1 \%$ of the anti-Torpedo acetylcholine receptor antibodies was found to be idiotype positive.

In addition to the polyclonal anti-idiotype antibodies, with which the above described analysis was performed, monoclonal anti-idiotypes were prepared against anti-acetylcholine receptor monoclonal antibody 65 . One of these monoclonals bound to an idiotope in the antigen binding site of monoclonal 65 , and another to a framework related idiotope. A monoclonal anti-idiotype recognizing a crossreactive idiotope on anti-acetylcholine receptor antibodies could be useful in the analysis of the idiotype profile of an anti-acetylcholine receptor immune response, and might be helpful in anti-idiotype manipulations of the idiotype-anti-idiotype network in myasthenia gravis. However, we did not find a monoclonal anti-idiotype binding to a crossreactive idiotope.

In chapter 6 the in vivo effects of neonatal administration of varying doses of anti-idiotype antibodies on the serum titer of anti-acetylcholine receptor antibodies, idiotype expression, and weight was studied in experimental autoimmune myasthenia gravis. Polyclonal affinity purified anti-idiotype antibodies directed at anti-acetylcholine receptor monoclonal antibody 65 were administred in dosages varying from the nanogram to the microgram range. Monoclonal anti-idiotype antibodies were tested in nanogram doses. No reproducible effect on the anti-acetylcholine receptor antibody titers or weight could be obtained during these experiments, al though in 1 out of 4 experiments administration of a nanogram dosage of anti-iditype antibodies led to an enhanced antibody response after imunization with acetylcholine receptor. Similarly, adoptive transfer of spleen cells from rats pretreated with a nanogram dosage of anti-idiotype antibodies resulted in an increased antibody response against acetylcholine receptor after immunization.

It has been demonstrated that anti-idiotype manipulations can result in altered idiotype expression, without affecting the total antibody response against a given antigen. Therefore, the idiotype expression was analysed, using the assay system as described in chapter 5 . No enhanced idiotype expression was found, as again less than $0.1 \%$ of the anti-Torpedo acetylcholine receptor antibodies was idiotype positive. 
Many variables determine the succes or fail ure of anti-idiotype manipulation, including age, the time interval between administration of anti-idiotype and the induction of disease, the dosage, and the isotype. Although it is not possible to test all combinations, we analysed polyclonal and monoclonal anti-idiotype antibodies in varying dosages, and studied the total antibody response as well as the idiotype expression. From these experiments we conclude that the polyclonal immune response against the acetylcholine receptor is idiotypically quite heterogeneous, in spite of the extensive crossreactivity that can be found at the level of monoclonal anti-acetylcholine receptor antibodies. Secondly, in vivo administration of polyclonal or monoclonal anti-idiotypes does not suppress the serum antibody level against the acetylcholine receptor, nor influences the idiotype profile of the immune response. Third, the idiotype mediated manipulaton of the immune response against large antigens, like the acetylcholine receptor, is clearly more complicated than that against small haptens, and more sensitive techniques, like adoptive transfer models, might be helpful in analysing the possibilities of anti-idiotype treatment in myasthenia gravis in more detail. 
SAMENVATTING 


\section{Samenvatting}

Myasthenia gravis is een autoimmuun ziekte, die gekarakteriseerd wordt door schade aan de postsynaptische spiermembraan, welke veroorzaakt wordt door antilichamen. Antilichamen gericht tegen de nicotine acetylcholine receptor spelen een centrale rol in de pathogenese van myasthenia gravis. Dit wordt duidelijk gedemonstreerd door het feit dat een zwangere de ziekte kan overdragen aan haar kind, of door het feit dat serum van een patient de ziekte kan overbrengen naar proefdieren en door het therapeutisch effekt van plasmaferese. Mogelijkheden om specifiek de produktie van deze auto-antilichamen te kunnen controleren en manipuleren zou een grote therapeutische doorbraak betekenen. Daarom is het belangrijk om over gedetailleerde informatie te beschikken aangaande het experimentele diermodel voor myasthenia gravis, om zodoende resultaten van nieuwe immuunmodulerende therapieën optimaal te kunnen beoordelen.

Doel van de studies, beschreven in dit proefschrift, was ten eerste om het rat model van experimentele autoimmuun myasthenia gravis te optimaliseren. Ten tweede werden de mogelijkheden tot regulatie van de anti-acetylcholine receptor antilichaam produktie middels idiotype-anti-idiotype interakties onderzocht.

Hoofdstuk 1 geeft een overzicht van de literatuur met betrekking tot myasthenia gravis en experimentele autoimmune myasthenia gravis. De struktuur en lokalisatie van de acetylcholine receptor wordt beschreven, aangezien het bekend is dat dit molekuul het meest belangrijke antigeen is in myasthenia gravis, waartegen de klinisch relevante antilichamen zijn gericht. Veel informatie over de struktuur van dit molekuul is nu beschikbaar; de acetylcholine receptor van vis, zoogdier, en mens is nu gekloneerd, en de exacte aminozuur volgorde is bekend. De antigene determinanten op de acetylcholine receptor zijn in kaart gebracht en meer dan honderd monoklonalen, met verschillende bindingsplaatsen op de receptor waaronder de acetylcholine bindingsplaats, zijn beschikbaar. Het merendeel van zowel de monoklonalen als in het serum vóórkomende antilichamen bind echter aan één extracellulaire determinant, de zogenaamde "main immunogenic region". De rol van $\mathrm{T}$ cellen in myasthenia gravis en experimentele myasthenia gravis wordt bestudeerd. Deze lymfocyten zijn betrokken bij cytotoxische aktiviteiten en bij de regulatie van de immunologische respons. Een aantal epitopen op de acetylcholine receptor, welke door T cellen herkend worden, is inmiddels geanalyseerd en deze epitopen bleken verschillend te zijn van de determinanten die door B cellen herkend worden.

Humane myasthenia gravis wordt kort besproken en meer aandacht wordt gegeven aan experimentele autoimmuun myasthenia gravis. Vooral het rat model van experimentele autoimmuun myasthenia gravis, opgewekt door immunisatie met acetylcholine receptor van de vis 'Torpedo californica', wordt 'selicht, aangezien dit model gebruikt is in de studies beschreven in dit proefschrift. Immunisatie met Torpedo acetylcholine receptor 
induceert een chronische ziekte, die in bijna ieder detail overeenkomt met het humane ziektebeeld, met uitzondering van de thymus afwijkingen die alleen bij de mens gezien worden. Pathomorfologie van de neuromusculaire overgang en mechanismen die leiden tot schade aan de eindplaat zijn gelijk in mens en dier. De destructie wordt veroorzaakt onder invloed van antilichamen en zowel in humane myasthenia gravis als in het chronische dierlijke equivalent worden zelden cellulaire infiltraten gezien. Het is aangetoond dat onder invloed van de anwezigheid van antilichamen de hoeveelheid acetylcholine receptoren op de eindplaat afneemt door processen als antigene modulatie en destructie van de spiermembraan door complement, en dat de antilichamen alleen al door binding in staat zijn de funktie van de acetylcholine receptor te blokkeren.

In hoofdstuk 2 wordt de relatie tussen anti-acetylcholine receptor antilichamen, de hoeveelheid acetylcholine receptoren in de spier en de klinische toestand in detail bestudeerd. In tegenstelling tot wat men zou verwachten, kunnen verschillen in de klinische toestand tussen myasthene ratten niet geheel verklaard worden door alleen te kijken naar het verlies van acetylcholine receptoren, aangezien er geen significante correlatie bestaat tussen de klinische toestand en het receptor verlies. Eerdere studies suggereerden dat de hoeveelheid acetylcholine receptor waaraan geen antilichaam gebonden is de klinische toestand bepaalt, aangezien bij mens en rat een wisselende hoeveelheid acetylcholine receptor gecomplexeerd bleek te zijn met antilichaam. Echter, wij tonen aan dat een groot deel van de acetylcholine receptor-antilichaam complexen in vitro gevormd worden gedurende de extractie van de acetylcholine receptoren uit de spier, en dat er een zeer goede relatie bestaat tussen de serum titer van anti-acetylcholine receptor antilichamen en de hoeveelheid complexen. Zodoende kan geconcludeerd worden dat veel minder acetylcholine receptoren in vivo antilichamen gebonden hebben dan eerder verondersteld werd. Met gebruik van een verbeterde methode voor het bepalen van acetylcholine receptor antilichaam complexen wordt geen relatie gevonden tussen antilichaam vrije receptor en de mate van ziekte. Tot slot wordt de rol onderzocht van anti-acetylcholine receptor antilichamen die in staat zijn de acetylcholine bindingsplaats te blokkeren. Even veel blokkerende antilichamen werden gevonden in het serum van myasthene ratten met en zonder symptomen van ziekte.

In hoofdstuk 3 wordt het gebruik van "single fiber" electromyografie voor de vroege opsporing van tekenen van experimentele myasthenia gravis in de rat beschreven. Tot dusver zijn gewicht, klinische symptomen en decrement van de spierpotentiaal gebruikt om de klinische toestand in myasthene ratten te evalueren. Uit studies in de mens is bekend dat deze electrofysiologische techniek gevoeliger is dan studie van decrement van de spierpotentiaal, aangezien hiermee verstoringen in de neuromusculaire signaaloverdracht ontdekt kunnen worden vóórdat blokkering van de impuls optreedt. De sensitiviteit van single fiber electromyografie voor het detecteren van een abnormale 
neuromusculaire funktie werd getest, en vergeleken met de bevindingen uit decrement studies, klinische symptomen, anti-acetylcholine receptor antilichaam titers, acetylcholine receptor en acetylcholine receptor-antilichaam complexen in de spier.

Vastgesteld werd dat single fiber electromyografie een sensitieve diagnostische test is in chronische experimentele autoimmuun myasthenia gravis. In zeven van de acht ratten die gëmmuniseerd waren met Torpedo acetylcholine receptor ontwikkelde zich een abnormale jitter, en dit ging altijd vooraf aan decrement van de samengestelde spierpotentiaal en het begin van klinische symptomen.

De omvang van de afwijkingen, die gevonden werden bij single fiber electromyografie, was niet proportioneell aan het verlies van acetylcholine receptor uit de gluteus medius spier, welke was gebruikt voor de electromyografische studies, noch met de hoeveelheid receptor in het gehele karkas. Evenals de resultaten beschreven in hoofdstuk 3, suggereert ook deze bevinding dat het totale verlies aan acetylcholine receptor niet de enige faktor is die verantwoordelijk gesteld kan worden voor een gestoorde neuromusculaire transmissie. Daarom dragen waarschijnlijk ook andere faktoren bij tot een abnormale jitter, zoals variatie in de struktuur van de postsynaptische membraan, of verdeling van acetylcholine of acetylcholine receptoren in een vergrote synaptische spleet, of allosterische blokkade van de receptor funktie door binding van antilichamen.

Hoofdstuk 4 introduceert het tweede deel van dit proefschrift. Het beschrijft de terminologie van de idiotypes en de anti-idiotypes, en de idiotype netwerk theorie van Jerne

Door analyse van de struktuur van een immunoglobuline is het mogelijk diverse antigene determinanten te onderscheiden op verschillende delen van het molekuul. Het isotype van een immunoglobuline bepaalt zijn klasse en subklasse (bijvoorbeeld $\lg _{\mathrm{G}} \mathrm{I}_{1}$ ), en is gellokaliseerd op het constante deel van het molekuul. Determinanten die alleen aanwezig zijn op immunoglobulines van bepaalde subgroepen in een populatie bepalen het allotype. Idiotypes zijn geassocieerd met antigene determinanten die op de variabele regio (V regio) van het immuunglobuline tot expressie worden gebracht, en een idiotype bestaat uit een verzameling idiotopen. Een idtotoop kan gevormd worden door de $V_{H}$ regio, de $V_{L}$ regio of door een combinatie van beide V regio's. Idiotopen kunnen worden ingedeeld op basis van hun localisatie, prevalentie, kruisreaktiviteit, of funktionele eigenschappen. Een belangrijke categorie van idiotopen zijn de kruisreagerende idiotopen. Kruisreagerende idiotopen zijn determinanten die gedeeld worden door verschillende immunoglobulines en deze zijn belangrijk voor de verbinding van antilichamen in een idiotype-anti-idiotype netwerk. Deze verbinding kan tot stand gebracht worden door anti-idiotype antilichamen die de idiotype determinanten van een antilichaam herkennen. In 1974 stelde Jerne als eerste voor dat idiotypes en anti-idiotypes onderling zijn verbonden in een netwerk dat een bellangrijke rol speelt in de regulatie van de immunologische respons. Vrij circulerende anti-idiotype antilichamen zijn aangetroffen bij patienten die lijden aan autoimmuun ziekten, waaronder myasthenia 
gravis, en talrijke studies ondersteunen nu een regulatoire rol voor anti-idiotype antilichamen. Verschillende idiotype interakties zijn naar voren gebracht als verklaring voor de inductie van myasthenia gravis. Een virus dat aan de acetylcholine receptor bindt zou, bijvoorbeeld, antilichamen kunnen induceren gericht tegen zijn bindingsplaats aan de receptor. Complementaire anti-idiotype antilichamen hiertegen zouden struktureel weer gelijk kunnen zijn aan de bindingsplaats van het virus en daardoor aan de acetylcholine receptor zelf kunnen binden. Op deze manier zou een autoimmunnreaktie tegen de receptor op gang kunnen komen. Aan de andere kant zouden micro-organismen bepaalde antigene determinanten met de receptor gemeenschappelijk kunnen hebben. Antilichamen gericht tegen deze microorganismen zouden dus ook in staat zijn zich aan de receptor te binden.

Kruisreagerende idiotopen kunnen therapeutisch belangrijk zijn. Sommige studies laten zien dat deze idiotopen gemakkelijk aan te tonen zijn in myasthenia gravis en in experimentele autoimmuun myasthenia gravis, terwijl andere de aanwezigheid van deze idiotopen niet hebben kunnen vaststellen. Het gebruik van verschillende monoklonale en polyklonale anti-acetylcholine receptor antilichamen en anti-idiotypes maakt de vergelijking van deze studies tamelijk moeilijk. Bijna alle studies analyseren idiotopen op de antigeen bindingsplaats, en maken geen analyse van de idiotopen gerelateerd aan daarbuiten gelegen "framework" determinanten. In experimentele autoimmuun myasthenia gravis zijn diverse anti-idiotype therapieën geprobeerd. De resultaten hiervan zijn zeer verschillend. Sommige studies tonen een aanzienlijke verlaging van de antilichaam titer, terwijl andere dit niet laten zien. Al deze studies weren verricht in volwassen dieren, maar het is bekend dat toediening van anti-idiotype antilichamen aan pasgeboren dieren een sterker en langer durend effekt teweeg kan brengen.

Wij bestudeerden de kruisreaktieve idiotopen geassocieerd met de antigeen bindingsplaats, en die geassocieerd met de "framework" determinanten van een serie goed gekarakteriseerde monoclonale anti-acetylcholine receptor antilichamen. De regulatoire eigenschappen van deze anti-idiotype antilichamen werden getest middels toediening aan pasgeboren ratten.

Hoofdstuk 5 beschrijft de analyse van vijf monoklonale anti-acetylcholine receptor antilichamen en twee controle myeloom antilichamen. Het idiotype profiel van drie van deze monoklonale antilichamen, gericht tegen de "main immunogenic region", kan belangrijk zijn omdat deze monoklonalen in staat zijn experimentele autoimmuun myasthenia gravis te induceren. Bovendien is ongeveer $50 \%$ van de anti-acetylcholine receptor antilichamen gericht tegen deze

"main immunogenic region". Het was mogelijk om kruisreagerende idiotopen geassocieerd met de antigeen bindingsplaats van deze drie monoklonalen te identificeren. Daarenboven werden gerelateerde kruisreaktieve idiotopen gevonden op alle vijf anti-acetylcholine receptor monoklonalen. Het voorkomen van antigeen bindingsplaats gerelateerde idiotopen kan verklaard worden door het feit dat deze mono- 
klonalen alle drie gericht tegen de "main immunogenic region", binden aan elkaar overlappende regio's op de acetylcholine receptor en daarom bepaalde conformaties in hun bindingslaats gemeenschappelijk hebben. Het voorkomen van kruisteactieve "framework" gerelateerde idiotopen op antilichamen met verschillende specificiteit kan niet worden verklaard door overeenkomsten in de struktuur van de antigeen bindingsplaats. Het zou echter verklaard kunnen worden door aan te nemen dat in de immuunrespons tegen auto-antigenen een beperkt aantal $V_{H}$ gen families wordt gebruikt. Het voorkomen van dezelfde idiotopen op antilichamen van eenzelfde $V_{H}$ gen familie, maar, met een verschillende specificiteit is beschreven. In feite kunnen deze kruisreactieve idiotopen opgevat worden als $V_{H}$ gen markers.

Alhoewel kruisreagerende idiotopen aangetoond konden worden op anti-acetylcholine receptor monoklonalen, was het moeilijk om de aanwezigheid van deze idiotopen in het serum van myasthene ratten te bepalen. Geen kruisreagerende idiotopen konden worden aangetoond indien gebruik gemaakt werd van inhibitie testen; slechts in een direkte bindingtest van anti-idiotypes aan affiniteits gezuiverde anti-acetylcholine receptor antilichamen konden kruisreagerende idiotopen in sera van myasthene ratten worden aangetoond. Minder dan $0.1 \%$ van de anti-Torpedo acetylcholine receptor antilichamen bleek idiotype positief te zijn.

Behalve polyklonale anti-idiotype antilichamen, waarmee de bovenstaande analyses zijn gedaan, werden ook monoklonale anti-idiotypes antilichamen bereid tegen antiacetylcholine receptor monoklonaal 65 . Eén van deze monoklonalen herkent een idiotoop in de antigeen bindingsplaats van monoklonaal 65, en een ander is gericht tegen een "framework" gerelateerde idiotoop. Een monoklonaal anti-idiotype, dat een kruisreagerende idiotoop herkent op anti-acetylcholine receptor antilichamen, zou nuttig kunnen zijn in de analyse van het idiotype profiel van een antilichaam respons tegen de anti-acetylcholine receptor. Ook zou een dergelijk monoklonaal behulpzaam kunnen zijn in anti-idiotype manipulaties van het idiotype-anti-idiotype netwerk in myasthenia gravis. Tot dusver echter vonden wij geen monoklonaal anti-idiotype dat bindt aan een kruisreagerende idiotoop.

In hoofdstuk 6 werden de in vivo effekten onderzocht van neonatale toediening van verschillende doses anti-idiotype antilichamen op de serum titer van anti-acetylcholine receptor antilichamen, idiotype expressie en gewicht. Affiniteits gezuiverde polyklonale anti-idiotype antilichamen gericht tegen anti-acetylcholine receptor monoklonaal 65 werden in verschillende doses toegediend, te weten vanaf nanogram tot microgram hoeveelheden. Monoklonale anti-idiotype antilichamen werden alleen getest in nanogram dosis. Geen reproduccerbaar effekt op de anti-acetylcholine receptor titer of gewicht kon worden verkregen in deze experimenten, alhoewel in eén van de vier experimenten toediening van een nanogram dosis polyclonaal anti-idiotype tot een verhoogde antilichaam respons na immunisatie met acetylcholine receptor leidde. "Adoptive transfer" van miltcellen van ratten die neonataal behandeld waren met een 
nanogram dosis anti-idiotype antilichamen resulteerde na immunisatie in een verhoogde antilichaam produktie tegen de acetylcholine receptor. Het is aangetoond dat antiidiotype manipulatie kan resulteren in een veranderde idiotype expressie, zonder de hoogte van de totale antilichaam respons tegen een bepaald antigeen te verstoren. Daarom werd ook de idiotype expressie geanalyseerd met gebruik van de test zoals die beschreven staat in hoofdstuk 5. Er werd geen verhoogde idiotype expressie gevonden, en opnieuw was minder dan $0.1 \%$ van de anti-Torpedo acetylcholine receptor antilichamen idiotype positief.

Vele variabelen bepalen het al dan niet slagen van anti-idiotype manipulatie, waaronder leeftijd van de ontvanger, het tijdsinterval tussen toediening van het anti-idiotype en induktie van de ziekte, en de dosis en het isotype van het anti-idiotype. Hoewel het niet mogelijk is om alle combinaties te testen, analyseerden wij polyklonale en monoklonale anti-idiotype antilichamen in verschillende doses. Ook werd zowel de totale antilichaam respons, als ook de idiotype expressie bestudeerd. Uit deze experimenten kan geconkludeerd worden dat de polyklonale immuunrespons tegen de acetylcholine receptor idiotypisch tamelijk heterogeen is, ondanks de uitgebreide kruisreaktiviteit die gevonden werd op het niveau van de monoklonale anti-acetylcholine receptor antilichamen. Ten tweede, in vivo toediening van polyklonale of monoklonale anti-idiotypes onderdrukt noch de serum antilichaam titer, noch het idiotype profiel. Ten derde, idiotype manipulatie van de immuunrespons tegen een groter antigeen, zoals de acetylcholine receptor, is duidelijk ingewikkelder dan dat tegen kleine haptenen. Meer gevoelige technieken, zoals adoptive transfer modellen zouden behulpzaam kunnen zijn bij de anallyse van de mogelijkheden van anti-idiotype behandeling van myasthenia gravis. 


\section{List of abbrevations}

\begin{tabular}{|c|c|}
\hline $\mathrm{ACh}$ & : Acetylcholine \\
\hline $\mathrm{AChR}$ & : Acetylcholine receptor \\
\hline Anti-Id & : Anti-Idiotype \\
\hline BT & : Bungarotoxin \\
\hline CFA & : Complete Freund adjuvant \\
\hline CRI & : Crossreactive idiotype \\
\hline EAMG & : Experimental autoimmune myasthenia gravis \\
\hline ELISA & : Enzym linked immune sorbent assay \\
\hline HRP & : Horse radish peroxidase \\
\hline Id & : Idiotype \\
\hline $\mathrm{mAb}$ & : Monoclonal antibody \\
\hline $\mathrm{MCD}$ & : Mean consecutive difference \\
\hline MEPP & : Miniature end-plate potential \\
\hline MIR & : Main immunogenic region (of the $A C h R$ ) \\
\hline MG & : Myasthenia gravis \\
\hline PBS & : Phosphate buffered saline \\
\hline RIA & : Radio immune assay \\
\hline SFEMG & : Single fiber electromyography \\
\hline
\end{tabular}




\section{Publications}

In the course of the studies, presented in part in this thesis, and those performed earlier, the following publications were elaborated.

Verschuuren J, Goei The HS, Schreutelkamp I, Houben HM, Burlage F, de Korte PH, Veldhuyzen van Zanten O (1987)

Radiological abnormalities of the manubriosternal joint in patients with rheumatoid arthritis and osteoarthrosis.

Scand J Rheum 16: 139-142

De Baets M, Verschuuren J, van Breda Vriesman P (1988)

Experimental autoimmune myasthenia gravis.

Monographs in Allergy 25: 1-12

De Baets M, Verschüuren J, Daha M, van Breda Vriesman P (1988)

Effects of the rate of acetylcholine receptor synthesis on the severity of experimental autoimmune myasthenia gravis.

Immunol Res 7: 200-211

Verschuuren JJGM, Spaans F, De Baets MH (1989)

Single fiber electromyography in experimental autoimmune myasthenia gravis.

Muscle and Nerve, Accepted for publication

Verschuuren JJGM, Graus YMF, Bos NA, Tzartos S, van Breda Vriesman PJC, De Baets MH

Paratope and framework related crossreactive idiotopes on acetylcholine receptor antibodies.

Submitted for publication.

Verschuuren JJGM, Graus YMF, van Breda Vriesman PJC, De Baets MH In vivo effects of neonatal administration of anti-idiotype antibodies on experimental autoimmune myasthenia gravis.

Submitted for publication 


\section{Proceedings and abstracts}

Verschuuren J, De Baets M, Theunissen R, Storms P, van Breda Vriesman PJC (1987)

Immunomodulation of the immune response against acetylcholine receptors in experimental autoimmune myasthenia gravis.

Fed Proc 46 (2): 1377, nr. 6189

Verschuuren J, De Baets M, Theunissen R, Storms P, Tzartos S, van Breda Vriesman PJC (1987)

Pertubation of the autoimmune idiotype network in experimental autoimmune myasthenia gravis.

2nd International congress of neuroimmunology. Philadelphia (abstract)

Verschuuren J, De Baets M, Theunissen R, Storms P, van Breda Vriesman P (1988)

Dose-dependent enhancement of the immune response against acetylcholine receptors in experimental autoimmune myasthenia gravis by anti-idiotypes.

FASEB Journall 2 (4): 3557 nr. A907

Spaans F, Verschuuren J, Geeraets L, De Baets M (1988)

Stimulated SFEMG in experimental autoimmune myasthenia gravis.

IIIth International Conference on computerised and single fiber EMG (abstract)

Verschuuren J, Graus Y, Henfling M, van Breda Vriesman P, De Baets M (1989) Crossreactive idiotypes on monoclonal and polyclonal antibodies against the nicotinic acetylcholine receptor.

FASEB Journal

Verschuuren JJGM, Bos GMJ, Majoor GD, De Baets MH, van Breda Vriesman PJC (1989)

'Spontaneous' myasthenia gravis in a rat after syngeneic bone marrow transplantation.

Proceedings of '2nd European conference on myasthenia gravis', p. 33 


\section{Tot slot}

Het is al vaker gezegd, promoveren doe je niet alleen. Zonder de hulp van de tallozen die mij met raad en daad terzijde hebben gestaan, had dit boekje hier nu niet gelegen. Van vele kanten heb ik de laatste jaren steun gekregen op de meest uiteenlopende manieren. Hetzij door hulp bij de uitwoering van experimenten, door mee te denken, door vragen of kritiek, hetzij door een steun in de rug, door voor me te zorgen, door aan me te denken, of me niet te storen. Op deze plaats wil ik dan ook enkele mensen, wiens hulp onmisbaar is gebleken, met name noemen.

Op de eerste plaats bedank ik het Beatrix fonds en de Nederlandse organisatie voor Wetenschappelijk Onderzoek (NWO), die het onderzoek financieel mogelijk maakten. Dan moet het team van de immunologie genoemd worden. Te beginnen met diegenen die mij op het laboratorium met hun kennis en vaardigheden ondersteunden. Pauline Storms, die mij op een plezierige en ontspannen manier de eerste kunsten van de ELISA en andere immunologische labvaardigheden bijbracht. Drs. R. Theunissen, beste Ruud, de geduldige precisie en inzet waarmee jij je voor het onderzoek inspande zijn onovertroffen. Ik vond het dan ook bijzonder jammer, toen jij je met andere zaken ging bezig houden. De moeilijke taak om jouw op te volgen kwam terecht bij drs. Y. Graus. Beste Yvo, hoeveel bergen werk je ook verzette, je deed het met een rust en nauwkeurigheid waarop ik blindelings kon vertrouwen. Daarnaast was er dan nog tijd voor een gezellige babbel, waarvan ik hoop dat het niet onze laatste zal zijn geweest. Mieke Henfling, beste Mieke, met jouw jarenlange labervaring en grote handvaardigheid heb je mij het laatste jaar zeer geholpen. Je hebt mij samen met Yvo het laatste jaar veel werk uit handen genomen en het was voor jullie nooit teveel als ik nog "even" een extra proefje had bedacht. Al deze mensen van het lab hebben, tezamen met Wien Vlek, die nimmer te weinig tijd had om me tussendoor te helpen of iets op te zoeken, een prima tijd bezorgd op het laboratorium, waaraan ik graag zal terug denken. Daarnaast wil ik alle andere medewerkers van de immunologie die me ieder op hun eigen wijze hebben geholpen van harte bedanken. Daarbij moet nog met name genoemd worden Francien Teng voor haar secretariële ondersteuning en de ex-promovendus, dr. G. Bos; beste Gerard, jouw uitdagende en kritische, maar altijd positief bedoelde opmerkingen werkten bijzonder verfrissend en ik hoop dat we ons contact op deze vriendschappelijke wijze kunnen voortzetten.

Naast deze mensen ben ik mijn dank verschuldigd aan de medewerkers van de dienst centrale proefdiervoorzieningen, die op nauwgezette wijze onze proefdieren hebben verzorgd. Gerrie Tilly en de andere medewerkers van de waskeuken, die altijd voor brandschoon glaswerk zorgden. Dr. S. Tzartos, dr. A. Vincent, prof. dr. H. Bazin, de vakgroep pathologie en medische microbiologie te Maastricht dank ik allen hartelijk voor het ter beschikking stellen van hun monoclonalen. Nico Bos ben ik erkentelijk voor de genetische analyse van enkele monoclonalen en de prettige samenwerking. 
Prof. dr. F. Spaans wil ik bedanken voor zijn enthousiaste ondersteuning van het "single fiber" onderzoek en Liesbeth Geeraets voor de perfecte technische assistentie bij de uitvoering hiervan.

Extra dank gaat uit naar Prof. dr. P. van Breda Vriesman en dr. M De Baets. Beste Peter, iik heb je in die jaren leren kennen als een man met hart woor de zaak en voor zijn promovendi. Jouw persoonlijke inbreng, kennis van zaken, en verrassende associatievermogen, leidde meer dan eens tot vernieuwende inzichten, maar maakte mij er ook iedere keer van bewust dat het onderzoek eigenlijk pas net begonnen was. Ik bedank je voor het aangename verblijf op jouw afdeling en hoop dat er ook in de toekomst gelegenheid zal zijn om samen een verfrissend flesje uit de koude kamer te nuttigen.

Beste Marc, voor jou een speciaal woord van dank, want zonder jouw inzet was het hele onderzoek niet mogelijk geweest. Zowel bij het opstarten van dit project, als in de loop van het onderzoek was jouw inhoudelijke bijdrage en vermogen om uitstekend hoofdvan bijzaken te onderscheiden essentieel om de grote lijn te blijven volgen. Naast de dagelijkse beslommeringen romdom het onderzoek, hebben we ook naast het werk de nodige aardige momenten beleefd; ik denk hierbij aan onze gezamenlijke congresbezoeken, maar ook aan de momenten waarbij jij jouw kennis van de vinologie met "praktijkvoorbeelden" illustreerde. Ik hoop dat zich ook in de toekomst nog voldoende momenten voordoen om samen op deze gezellige tijd terug te blikken.

Tot slot will ik Ank, mijn ouders, familie en vrienden bedanken voor het geduld op de momenten dat ik er weer niet (op tijd) was, omdat ik werd opgeslokt door het onderzoek. Hoewel onderzoek doen voor mij behoorlijk verslavend werkte, hoop ik nu toch tot een aanvaardbaar niveau te kunnen afkicken. 


\section{Curriculum vitae}

Jan Verschuuren werd geboren op 25 januari 1961 in Breda. Hij behaalde in 1979 het eindexamen gymnasium $\beta$ aan het Coriovallum College in Heerlen. Vervolgens studeerde hij geneeskunde an de Rijksuniversiteit Limburg te Maastricht, welke studie voltooid werd in 1985. Zijn eerste kennismaking met het wetenschappelijk onderzoek vond plaats op de afdeling Rheumatologie van het De Wever ziekenhuis te Heerlen bij dr. H. Goei The. Hierna was hij, gesteund door een beurs van de nederlandse organisatie voor wetenschappelijk onderzoek (NWO), werkzaam op de afdeling Immunologie (Prof. dr. P.J.C. van Breda Vriesman), waar hij dit proefschrift voltooide onder leiding van dr. M.H. De Baets. Sinds juli 1989 is hij in opleiding tot neuroloog bij de vakgroep Neurologie in het Academisch Ziekenhuis te Maastricht (Prof. dr. P.J.M. van der Lugt). 